University of Nebraska - Lincoln

DigitalCommons@University of Nebraska - Lincoln

Agronomy \& Horticulture -- Faculty Publications

Agronomy and Horticulture Department

$10-1944$

\title{
Nature and Degree of Recovery of Grassland from the Great Drought of 1933 to 1940
}

\author{
F. W. Albertson \\ Fort Hays Kansas State College \\ J. E. Weaver \\ University of Nebraska-Lincoln
}

Follow this and additional works at: https://digitalcommons.unl.edu/agronomyfacpub

Part of the Plant Sciences Commons

Albertson, F. W. and Weaver, J. E., "Nature and Degree of Recovery of Grassland from the Great Drought of 1933 to 1940" (1944). Agronomy \& Horticulture -- Faculty Publications. 476.

https://digitalcommons.unl.edu/agronomyfacpub/476

This Article is brought to you for free and open access by the Agronomy and Horticulture Department at DigitalCommons@University of Nebraska - Lincoln. It has been accepted for inclusion in Agronomy \& Horticulture -Faculty Publications by an authorized administrator of DigitalCommons@University of Nebraska - Lincoln. 
NATURE AND DEGREE OF RECOVERY OF GRASSLAND FROM THE GREAT DROUGHT OF 1933 TO 1940

F. W. Albertison

Fort Hays Kansas State College

and

J. E. Weaver

University of Nebraska 


\section{TABLE OF CONTENTS}

\begin{tabular}{|c|c|c|}
\hline & PAGE & \\
\hline INTRODUCTION $\ldots \ldots \ldots \ldots \ldots$ & 395 & RECOVERY OF VEGETATION \\
\hline Environment in True Prairie & 396 & Examples of recovery .. \\
\hline Precipitation $\ldots \ldots \ldots \ldots \ldots$ & 396 & Recovery in ungrazed Buchloe-Bouteloua type \\
\hline Evaporation $\ldots \ldots \ldots$ & 396 & Recovery in moderately grazed Buchloe-Bouteloua \\
\hline Water content of soil ...... & 397 & tуре $\ldots \ldots \ldots \ldots \ldots \ldots \ldots \ldots \ldots \ldots \ldots \ldots$ \\
\hline SEVERITY OF DROUGHT IN 1934. & 398 & Recovery in overgrazed Buchloe-Bouteloua type .. \\
\hline Evaluation of Conditions in $1935 \ldots$. & 398 & Recovery in the Andropogon scoparius type ..... \\
\hline Decrease in perennial grasses $\ldots . \ldots \ldots$ & 398 & Recovery in little bluestem-short grass mixture .. \\
\hline 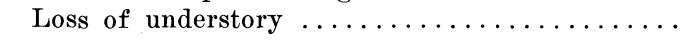 & 398 & Percentage change in composition of basal cover 4 \\
\hline Increase in certain native forbs & 399 & Studies in west central Kansas $\ldots \ldots \ldots \ldots \ldots$ \\
\hline Invasion of ruderals $\ldots \ldots \ldots \ldots \ldots \ldots \ldots \ldots$ & 400 & 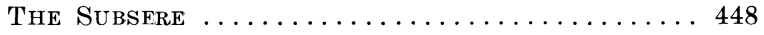 \\
\hline Increase of certain native grasses $\ldots \ldots \ldots \ldots \ldots$ & 400 & Conditions for succession $\ldots \ldots \ldots \ldots \ldots \ldots \ldots$ \\
\hline Recurrence of Severe Drought $\ldots \ldots \ldots \ldots \ldots$ & 401 & Stages of succession $\ldots \ldots$ \\
\hline RECOVERY IN 1938 & 401 & Examples of seral stages \\
\hline Drought of $1939-1940 \ldots \ldots \ldots \ldots \ldots \ldots \ldots$ & 402 & Early weed stage ..... \\
\hline Recovery; Development of Grassland Types . & 403 & Medial stage .... \\
\hline The subsere $\ldots \ldots \ldots \ldots \ldots \ldots \ldots \ldots$ & 404 & Early, medial, and climax stages $\ldots \ldots \ldots$ \\
\hline$\ldots \ldots \ldots, \ldots, \ldots, \cdots$, & 404 & First weed stage $\ldots \ldots \ldots \ldots \ldots \ldots \ldots \ldots$ \\
\hline$\ldots \ldots \ldots \ldots \ldots$ & 405 & a pestifer $\ldots \ldots \ldots \ldots \ldots \ldots \ldots \ldots$ \\
\hline orbs and grasses & 406 & $\ldots \ldots \ldots \ldots \ldots \ldots \ldots$ \\
\hline Need & 409 & \\
\hline Prai & 411 & is an \\
\hline grass type $\ldots \ldots \ldots \ldots \ldots$ & 411 & pis nuttalliana . \\
\hline at grass in comparison with & & laca oleracea ... \\
\hline$\ldots \ldots \ldots \ldots \ldots \ldots$ & 413 & усе $\ldots . . \ldots$. \\
\hline 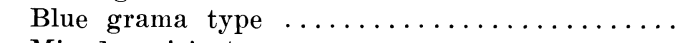 & 415 & 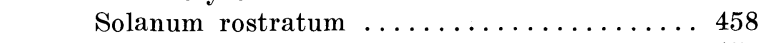 \\
\hline & 416 & $\mathrm{n}$ canadense $\ldots \ldots \ldots \ldots \ldots \ldots$ \\
\hline Big & 417 & Second weed stage $\ldots \ldots \ldots \ldots \ldots \ldots \ldots$ \\
\hline em-little bluestem type $\ldots \ldots \ldots$. & 418 & Hordeum pusillum ... \\
\hline$\ldots \ldots \ldots \ldots \ldots \ldots \ldots \ldots \ldots$ & 419 & m capillare $\ldots \ldots \ldots \ldots \ldots \ldots \ldots$ \\
\hline Recovfry of Native Grasses That Did Not & & anensis $\ldots \ldots \ldots \ldots \ldots \ldots$ \\
\hline$\ldots \ldots \ldots \ldots \ldots \ldots \ldots$ & 421 & hirtella ... \\
\hline ( & 421 & spp. \\
\hline Ko & 422 & um densiflorum. \\
\hline & 422 & go spp. $\ldots \ldots$ \\
\hline & 423 & 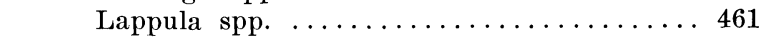 \\
\hline & 423 & antha crassisepala $\ldots \ldots \ldots \ldots \ldots \ldots$ \\
\hline$\ldots \ldots \ldots \ldots$ & 424 & \\
\hline Meth & 424 & Early \\
\hline $\mathrm{V}$ & 424 & Sporobolus eryptandrus \\
\hline of dormancy. & 424 & yron smithii $\ldots \ldots \ldots$ \\
\hline & 426 & nnardus paniculatus .. \\
\hline ery $\ldots \ldots \ldots \ldots \ldots \ldots \ldots$ & 428 & a squarrosa $\ldots \ldots \ldots \ldots \ldots \ldots \ldots$ \\
\hline and stature $\ldots \ldots \ldots \ldots$ & 428 & verticillata \\
\hline & 429 & stages in the two subseres ... \\
\hline ght of postclimax prairie ... & 431 & Late $g$ \\
\hline 0 & 432 & \\
\hline Discussion $\ldots \ldots \ldots \ldots \ldots \ldots \ldots \ldots \ldots \ldots \ldots \ldots$ & 433 & Buchloe dactyloides ... \\
\hline Environment in Mixed Prairie $\ldots \ldots \ldots \ldots \ldots$ & 434 & Bouteloua curtipendula..... \\
\hline & 434 & Recovery of POSTClimax Vegetation \\
\hline Water content of soil & 435 & Recovery as Expressed in YieLd .... \\
\hline & 435 & RETURN OF FORBS $\ldots \ldots \ldots \ldots \ldots$ \\
\hline & 437 & \\
\hline Temperature & 438 & Literature Cited \\
\hline
\end{tabular}




\section{NATURE AND DEGREE OF RECOVERY OF GRASSLAND FROM THE GREAT DROUGHT OF 1933 TO 1940*}

\section{INTRODUCTION}

For eight years drought had prevailed in the midcontinental grasslands. The true prairie west of Minnesota, Iowa, and Missouri had been woefully depleted. Mixed prairie farther westward to the Rocky Mountains had been nearly or entirely destroyed. But now the parched soil was wet once more, wet to a depth of several feet. The hot dry air was now warm and moist. The terrible dust storms had ceased. A changed environment had come at last, for this was the end of the long period of drought. Thus, in 1941 the long delayed recovery of vegetation began. The nature of this complex phenomenon was now to be revealed and the sequence of recovery to be recorded.

It was with new hope but also with a sense of

* Contribution No. 143 from the Department of Botany, University of Nebraska. These studies were aided by a grant from the Penrose Fund of the American Philosophical Society, and one from the University Research Council, University of
Nebraska. new responsibility that the writers continued their field studies. For here was nature at work repairing the damage of a great catastrophe, a catastrophe that has probably occurred many times in the long history of grassland, but one of which there is no written record. Methods were a continuation of those used in previous studies. In permanent quadrats, which were charted or clipped, in selected prairies and ranges where extensive histories had been built up year by year, and by annually photographing definite areas, nature has been permitted to tell her own story of progressive recovery. Special attention has been given to the reproduction, migration, establishment, and competition of individual species of grasses and forbs, and to plant succession. Intensive studies were combined with extensive observations in as many widely separated stations as seemed feasible (Fig. 1). It seems clear that the methods and sequence of recovery in this large section of midcontinental grassland are in general, and often in particular, the same

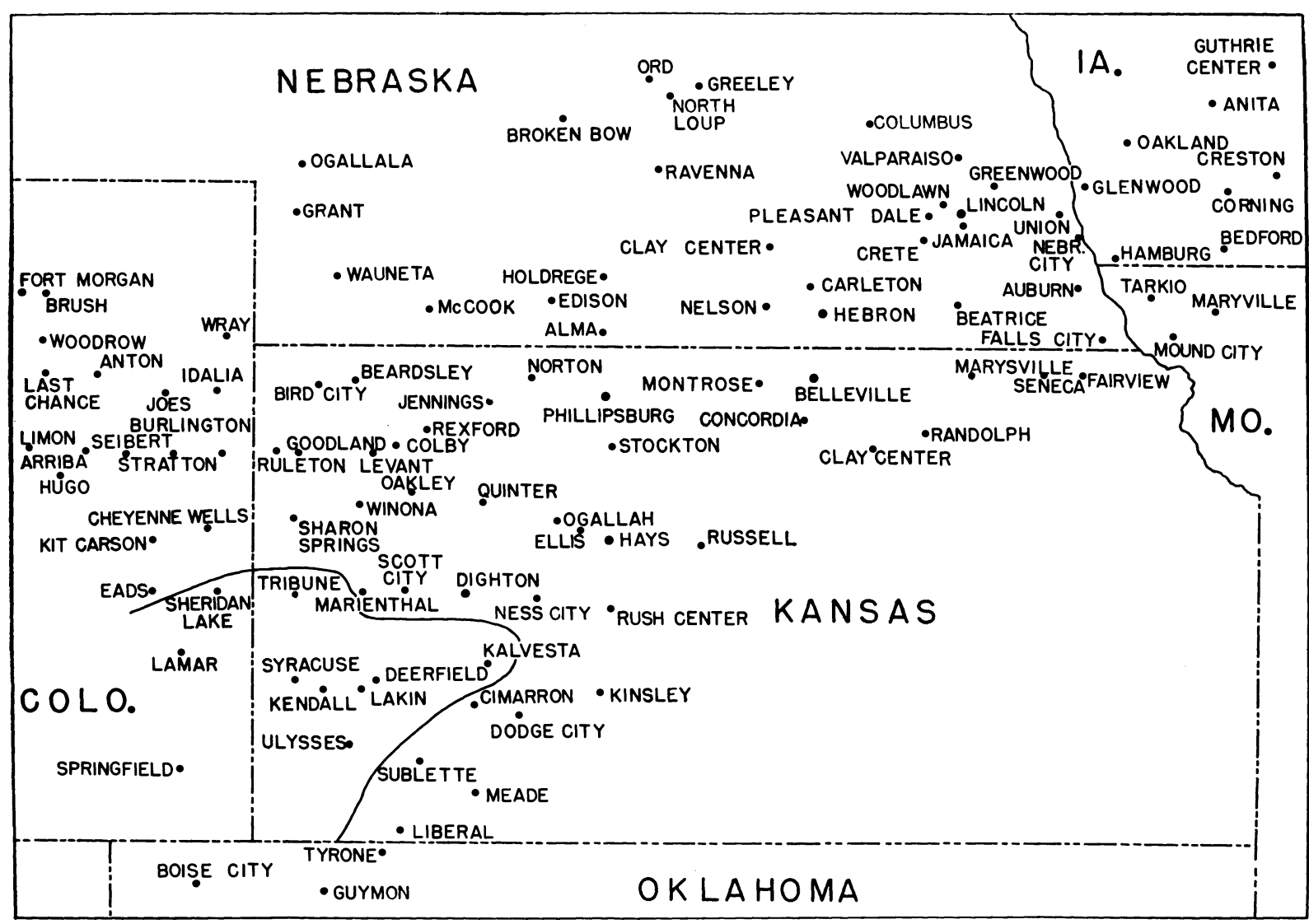

Fig. 1. Outline map of the region showing stations mentioned in the text and figures and certain other stations where studies were conducted. The general area where the basal cover was nearly always less than 35 per cent in 1943 lies south and west of the irregular line. 
as those in the range lands from southern Canada to central Texas. For convenience of presentation, and because the dominant grasses of true and mixed prairie are often different, recovery in true prairie has been described first. This is also in agreement with earlier reports (Weaver \& Fitzpatrick 1932, 1934; Weaver, Stoddart, \& Noll 1935; Albertson 1937, 1938, 1939, 1941; Albertson \& Weaver 1942, 1944; Weaver \& Albertson 1936, 1939, 1940, 1940a, 1943).

\section{ENVIRONMENT IN TRUE PRAIRIE}

Conditions in grasslands have been ameliorated greatly since the end of the drought. Changes can best be appreciated by comparing the water relations as expressed by precipitation, evaporation, and soil moisture with those of the final years of desiceation.

\section{Precipitation}

The mean annual precipitation at Lincoln and Hebron, Nebraska, and at Belleville, Kansas, is 27.9, 27.3, and 26.2 inches, respectively. Precipitation at each of these stations during the last two drought years (1939-40) and the three of postdrought is shown in Figure 2. The differences in precipitation during drought and recovery are especially marked in the very high rainfall (except at Lincoln) in 1941, when Hebron received 39.8 inches and Belleville 42.2.

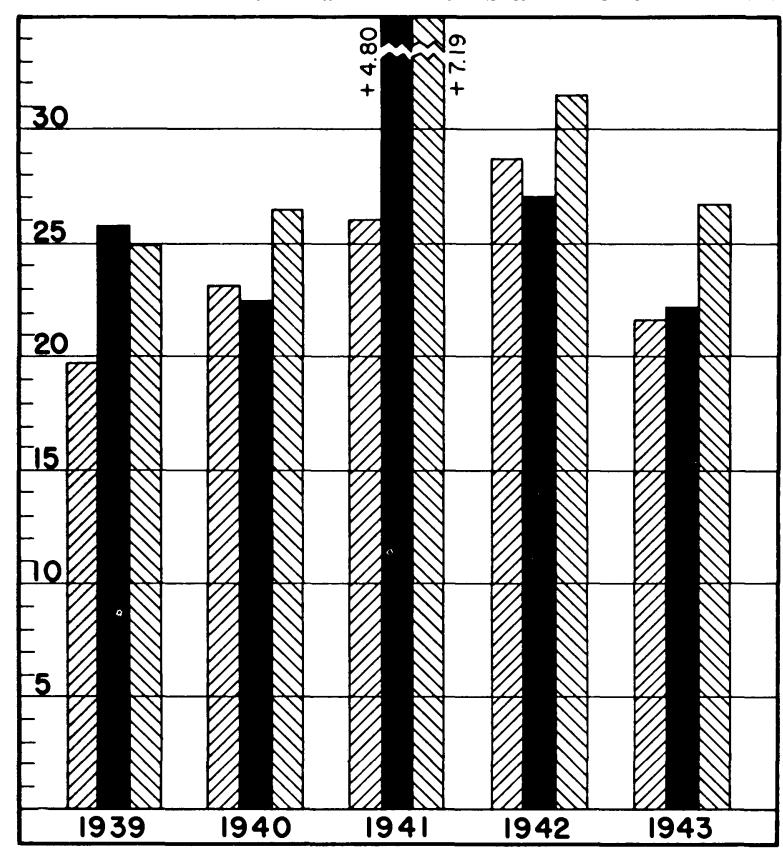

Fig. 2. Annual precipitation in inches at Lincoln (left) and Hebron (black bar), Neb., and Belleville, Kan. (right), 1939 to 1943 inclusive.

This abnormally high annual precipitation was due largely to more than 11 inches at both stations in June, and 10 and 7.6, respectively, in September. This excess moisture wet the subsoil to at least 6 feet in depth (Weaver \& Albertson 1943). Hence, the nearly normal precipitation the following year promoted excellent growth. Rainfall in 1943 was about the same in amount as that in 1940. Actually, in 1943 an excellent yield of grasses was produced. The soil had a good reserve of water in spring, and rainfall was normal or far above normal from April until August (Fig. 3). Thus, rainfall was nearly as high and often much higher from April to August than during the preceding year. But late summer drought occurred at all stations in August and September.
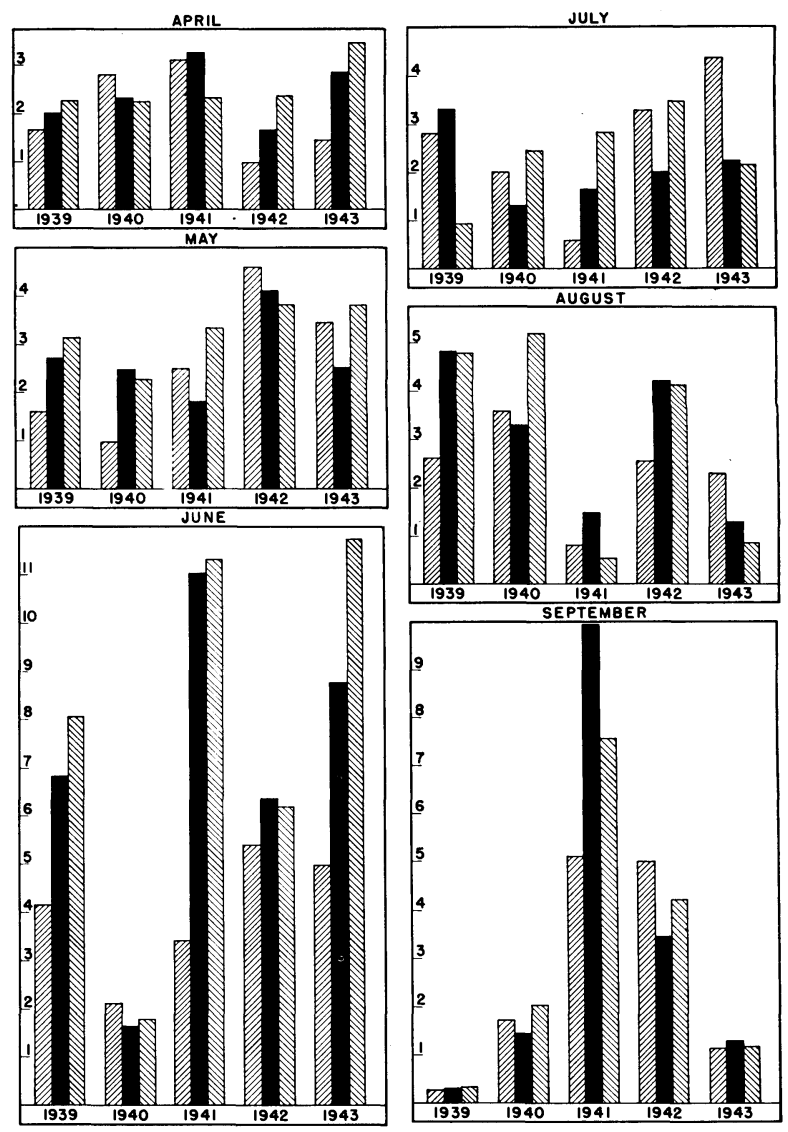

Fig. 3. Precipitation in inches by months at Lincoln (left), Hebron (black bar), and Belleville (right) 1939 to 1943 inclusive.

\section{Evaporation}

The monthly evaporation from a free water surface, as recorded by the U. S. Department of Agriculture at Lincoln, is shown in Table 1.

TABLE 1. Monthly evaporation in inches and total evaporation for the six summer months at Lincoln, Nebraska.

\begin{tabular}{c|c|c|c|c|r|c|c}
\hline \hline Year & Apr. & May & June & July & Aug. & Sept. & Total \\
\hline $1939 \ldots \ldots$ & 6.3 & 9.4 & 8.7 & 10.7 & 8.8 & 9.9 & 53.8 \\
$1940 \ldots \ldots$ & 4.4 & 6.2 & 8.4 & 11.4 & 6.2 & 5.8 & 42.4 \\
$1941 \ldots \ldots$ & $\ldots .1$ & 7.1 & 7.0 & 10.9 & 10.2 & 6.6 & $\ldots .$. \\
$1942 \ldots \ldots$ & 6.1 & 5.6 & 6.8 & 9.4 & 8.0 & 4.3 & 40.2 \\
$1943 \ldots \ldots$ & 6.8 & 6.2 & 7.9 & 8.9 & 8.1 & 5.5 & 43.4 \\
\hline
\end{tabular}

Examination of Table 1 shows at once the very high evaporation rate during each month in 1939 and 
the high total of 53.8 inches. Although the total loss decreased to 42.4 inches the next year, that of both June and July was higher than on any of the following years. Water loss in 1942 and 1943 totaled 13.6 and 10.4 inches less, respectively, than that of 1939.

\section{Water Content of SoIL}

Since much precipitation may be lost not only by runoff and interception by the plant cover, but also by direct evaporation from the soil as well, a more accurate picture of the amount of water available for plant growth may be obtained by frequent soil sampling. Water content to a depth of 6 feet was ascertained in 1939 to 1941, inclusive, at all three stations (Weaver \& Albertson 1940, 1943). This work was continued during 1942 and 1943 at Lincoln, and samples were also taken occasionally at the other stations. In general, amounts of soil moisture at Hebron and Belleville were similar to (but at times greater than) those ascertained in the upland prairie at Lincoln. Percentages of water in the charts are those of total water content of soil minus the hygroscopic coefficient, which was determined for each soil depth. This is considered as water available for growth. The samples were all from a Carrington silt loam with a mature profile. The hygroscopic coefficients at the several depths were 8.9 and 8.4 per cent in the first foot and 10.5, 11.1, 9.7, 10.8, and 11.2, respectively, for each successive foot in depth to six feet. After 1940 samples were obtained from a new but adjacent sampling area where the hygroscopic coefficients, in the same sequence of depths, were 9.0 and 9.6, 9.9, $10.6,12.8,13.5$, and 14.0 per cent, respectively.

In 1939, early spring sampling showed an available water supply of 5 to 20 per cent or more in the surface two feet (Fig. 4). Between 2 and 6 feet in depth there was 2 to 5 per cent of water available, a condition which prevailed throughout the growing season. No water was available for growth in the

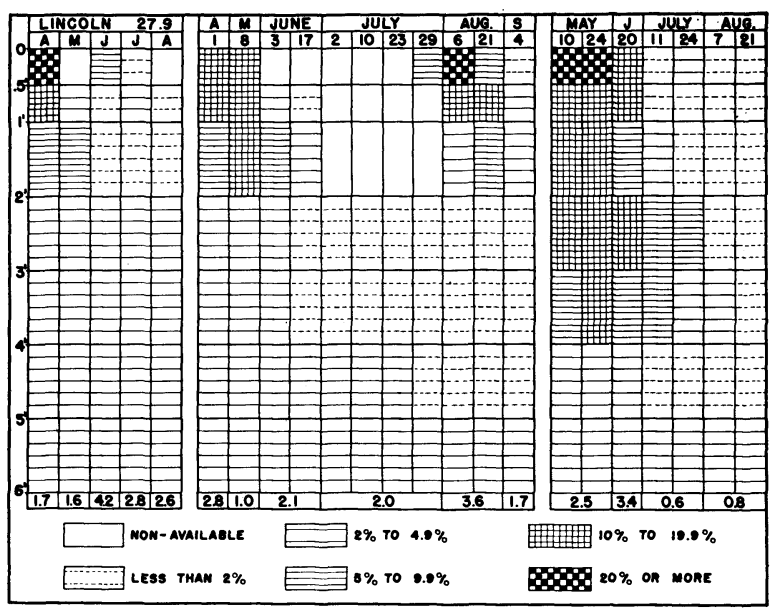

FIG. 4. Available soil moisture to a depth of 6 feet at Lincoln, Neb., during 1939 (left panel), 1940 (center), and 1941 (right panel). Mean annual precipitation is 27.9 inches. Numbers at top of the columns are dates of sampling; those at the base are total current monthly rainfall in inches.
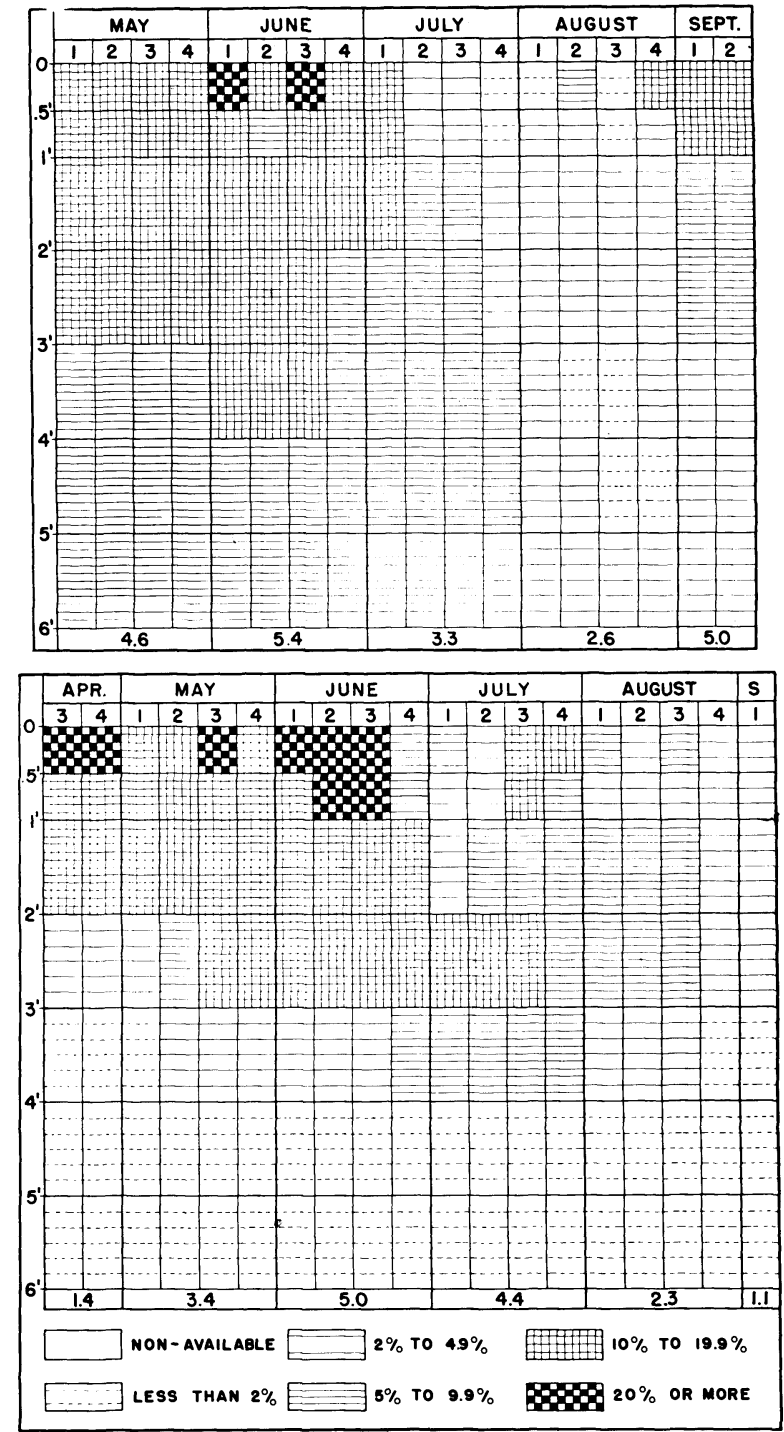

Fig. 5. Available soil moisture to a depth of 6 feet at Lincoln, Neb., during 1942 (upper) and 1943 (lower). Numbers at top of columns indicate the first, second, etc., week of the month; those at the base are total current monthly rainfall.

surface 6 inches of soil in May or August, and the 6 - to 24-inch depth had less than 2 per cent water available nearly throughout June, July, and August.

In 1940, drought began in June and was very severe throughout July. No water was available for growth in either the first or second foot of soil, and less than 2 per cent in the third and fourth foot. Dry subsoil prevailed until September, although rains in August moistened the upper 2 feet.

That soil moisture was much higher in May and June of 1941 is elear. But at this station deficient rainfall both in July and August resulted in late summer drought. Conditions were greatly improved in 1942, the weekly samples revealing only rarely a temporary reduction of available water to less than 2 per cent (Fig. 5). Ten per cent or more water 
was constantly available in the soil in April, May, and June of 1943. Even during July, August, and early September, 2 to 10 per cent moisture was constantly present. But in the subsoil below 4 feet the deeply rooted vegetation had depleted the supply until less than 2 per cent was available.

The water relation was the controlling factor in drought. Water loss from both plant and soil was accelerated, however, by high temperatures, dry air, and excessive wind movement. During the three years of recovery temperatures were not abnormally high as they were during the drought years, nor was humidity unusually low. Wind movement was less than during the drought, and dust storms did not occur.

\section{SEVERITY OF DROUGHT IN 1934}

The most severe drought ever recorded in true prairie occurred in 1934. It began in early spring and became intensified with the progress of the season. Soil moisture was gradually depleted. By July, no water to a depth of 4 feet was available for growth on the uplands. Beginning after the middle of June and continuing until late in July, a terrific heat wave swept over the prairie. The scorching sun seared the grasses as if by fire, and life in all but the most deeply rooted forbs retreated underground. No rain fell, clouds were rare, the light was intense, and hot southerly winds blew as from a desert. After bleaching the upland vegetation to patches of brown and white, drought crept down the slopes, even into mesic and hydric ravines (Fig. 6). Here the vegetation first exhibited the yellow-green color characteristic of great drought, then most of the grasses wilted and dried. Only on the best protected, northfacing hillsides did the belt of green extend a little way up the slopes. On lowlands along the Missouri River, entire meadows of big bluestem were wilted or dried, the red and bronze colors of late autumn appearing in August. Even slough grass was

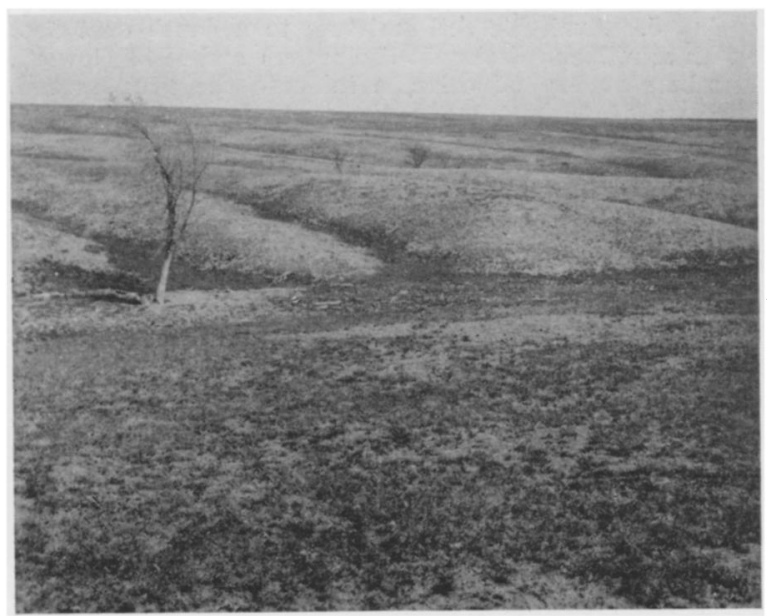

Fig. 6. Effects of drought on grassland. Bluestem pasture near Lincoln, Neb., on April 20, 1935. Nearly all of the native grasses (light colored) have been killed and Kentucky bluegrass is alive only in the ravines. dwarfed, wilted, and the foliage half dry, and cattails in the marshes became dry and brown (Weaver \& Albertson 1936).

\section{EVALUATION OF CONDITIONS IN 1935}

The degree of destruction was ascertained during the following growing season. Fortunately this was one of approximately normal precipitation and afforded conditions favorable to the recovery of vegetation. Changes were evaluated in more than 30 prairies in Iowa, Nebraska, and east-central Kansas. Each of these had been fully studied just before the drought (Weaver \& Fitzpatrick 1934).

\section{Decrease in Perennial Grasses}

Most prairies on the deep loess and glacial soils of southwestern Iowa had not been harmed. Others had suffered a loss of 20 to 50 per cent of certain grasses on the most exposed slopes. Death by drought increased southwestward, from very great losses on slopes and hilltops to $80-90$ per cent destruction even on nearly level areas farther west. All of the native grasses suffered some loss, but death was greatest among those with relatively shorter roots: little bluestem (Andropogon scoparius), June grass (Koeleria cristata), needle grass (Stipa spartea), and the invading Kentucky bluegrass (Poa pratensis). Losses often occurred widely but especially where these grasses occupied the drier soils. Prairie dropseed (Sporobolus heterolepis) also sustained losses which, like those of Indian grass (Sorghastrum nutans), often amounted to 80 or more per cent. Big bluestem (Andropogon furcatus), because of its deeper root system, was usually injured least. Losses among interstitial low grasses and forbs were often practically complete after the protecting cover of the tall grass dried (Fig 7).

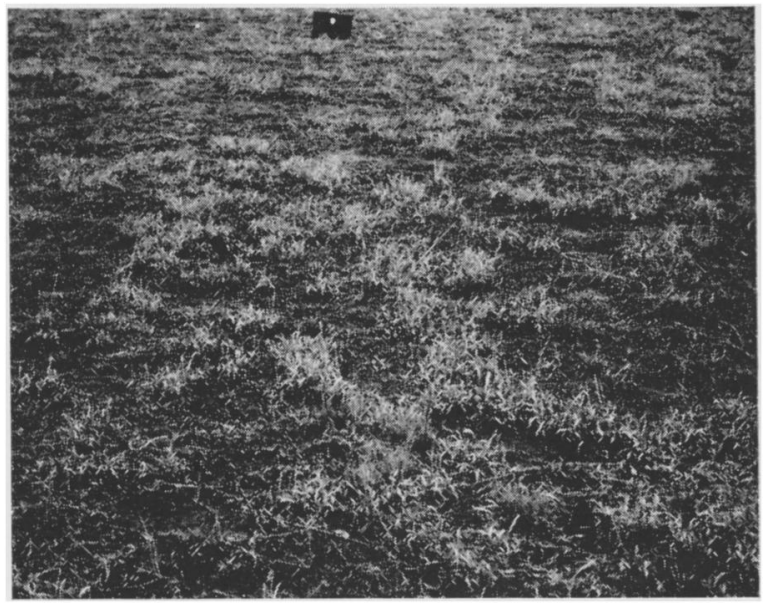

Fig. 7. Bared soil between bunches of relict grasses, mostly big bluestem and side-oats grama, on north-facing slope near Valparaiso, Neb., May, 1936.

\section{LOSS OF UNDERSTORY}

This great destruction to species of the understory gave the grassland its distinctly open appearance. Among these species, the following were most con- 
spicuous: Kentucky bluegrass, Seribner's panic grass (Panicum scribnerianum) and various other species of panic grasses of low stature, purple lovegrass (Eragrostis spectabilis), and ticklegrass (Agrostis hiemalis). Forbs which suffered great losses were prairie cat's-foot (Antennaria campestris), violets (Viola papilionacea and V. pedatifida), and species of milkwort (Polygala). The same was true of downy gentian (Gentiana puberula), prairie ragwort (Senecio plattensis), species of ground-cherry (Physalis), and rosettes of hawkweed (Hieracium longipilum). Moreover, the soil mulch of fallen leaves, etc., had almost entirely disappeared.

Where drought was only moderately severe, the small patches of bare soil, a square foot or less in area, were so plentiful that they formed an irregular but continuous network among the widely spaced plants (Fig. 8). Where destruction of vegetation had been greater, these openings of small size graded into larger ones, one to several square yards in extent

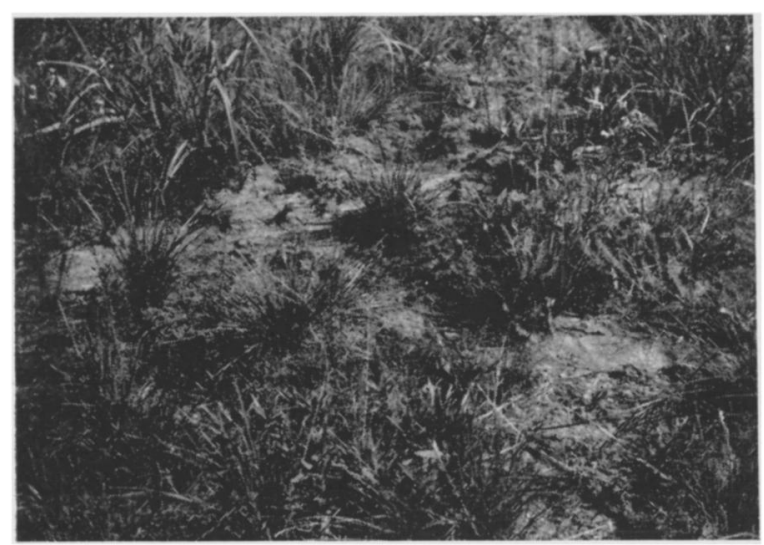

Fia. 8. Effect of drought in producing much bare soil in climax cover of bluestem grasses on a north-facing slope near Lincoln, Neb. Photo in July, 1938, after considerable recovery.

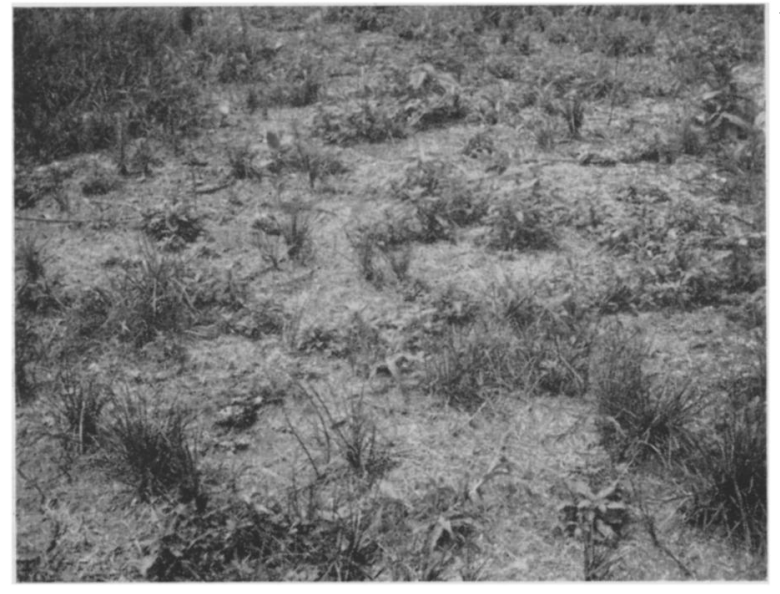

Fig. 9. Typical nearly bared space in bluestem prairie except for some surviving tufts of grass and a few rough pigweeds and other ruderals. Note presence of much bare soil. Photo in June, 1939.
(Fig. 9). Elsewhere the plant cover was so decimated that the soil appeared almost bare. It had maintained only the remnants of a former population (Weaver \& Albertson 1936).

Seedlings of most native grasses were not abundant in 1935. The dry spring was unfavorable to early germination; the soil had lost its mulch of debris, and there was often little protecting shade. Seedlings of many-flowered aster (Aster multiflorus), daisy fleabane (Erigeron ramosus), and weedy species were produced in abundance.

\section{Increase of Certain Native Forbs}

Certain widely distributed, long-lived forbs immediately profited by the thinning of the prairie cover. They spread rapidly and widely. Aster multiflorus became a bad weed in many of the prairies throughout the entire area, but not in all. It was almost absent in some that were greatly disturbed. It ranged from great local abundance to complete temporary control over one-fifth to one-half of certain large prairies (Fig. 10). So numerous were the somewhat woody, tangled stems produced from the widely branching rhizomes, that they formed an almost thicket-like growth. Beneath them were the dead crowns of the bluestems or intermixed with them were the relicts of big bluestem and other grasses. Other perennial forbs that were of unusual local abundance in some of the prairies were smooth goldenrod (Solidago glaberrima) and prairie mugwort (Artemisia gnaphalodes).

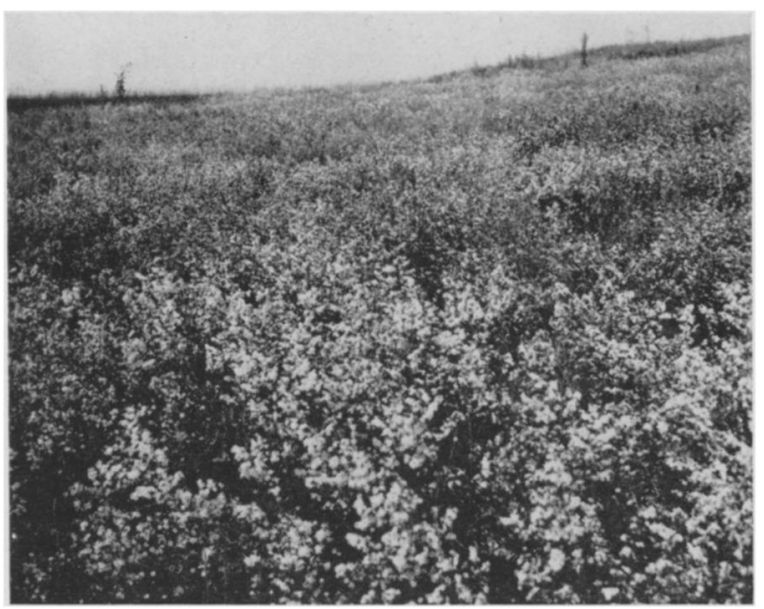

Fig. 10. A hillside in drought-bared prairie almost completely covered with Aster multiflorus. This nearly worthless native forb spread widely over hundreds of prairies following the opening of the sod. Photo in September, 1938, Lincoln, Neb.

The winter annual, Erigeron ramosus, had become a bad weed in about half of the drought-damaged prairies. It grew so thickly that frequently 20 to 30 plants per square decimeter clothed the bare soil where the grasses had died. The stems attained a height of 12 to 30 inches and dried in midsummer. Other annual prairie forbs that occurred in very great abundance but only during this first year following 
the drought were sleepy catchfly (Silene antirrhina) and Venus' looking-glass (Specularia perfoliata).

\section{INVASION OF RUDERALS}

Certain ruderals, normally not found in prairies, became widely distributed. Peppergrass (Lepidium densiflorum) was common to abundant in the bare places throughout nearly all of the prairies. This weed was often a good indicator of the amount of bared space (Fig. 11). In many places it grew so thickly

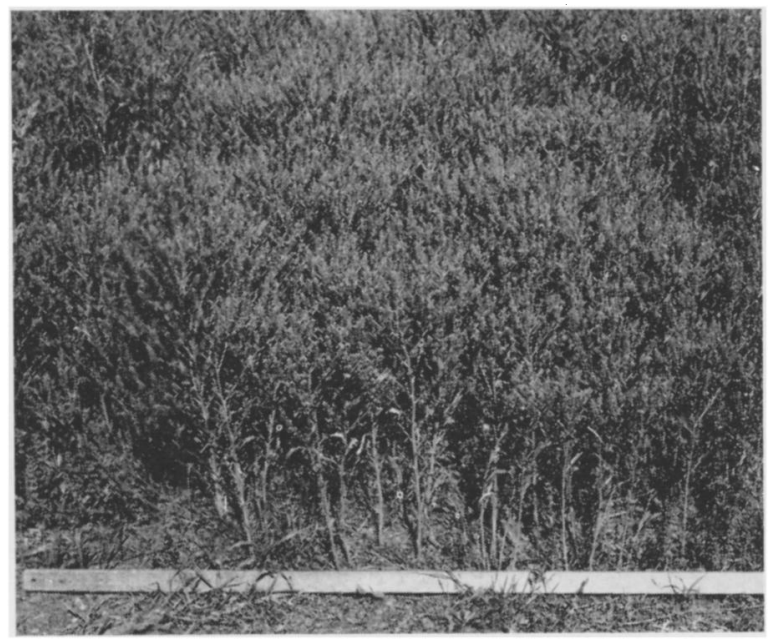

Fig. 11. Dense stand of peppergrass (Lepidium densiforum), a weed which was very abundant following the early years of drought. Average height is 14 inches. Photo June 7, 1937.

that the seed literally covered the soil beneath the densely aggregated plants. Horseweed (Leptilon canadense), with stems frequently 2.5 to 3.5 feet tall, was common to abundant in the prairies of the eastern half of the area and in some of the more westerly ones. Goatsbeard (Tragopogon pratensis) occurred most abundantly eastward. It varied from dense stands to widely scattered plants, but was always very conspicuous. Chess (Bromus secalinus) occurred in very great abundance in the western part of the area where it frequently covered whole hillsides in the drought-stricken grassland. Downy brome ( $B$. tectorum) also was found in moderate amounts but mostly eastward. Where wind-blown dust had covered considerable portions of certain prairies, numerous annual weeds grew thickly. Chief among these were Russian thistle (Salsola pestifer), lamb's quarters (Chenopodium album), and rough pigweed (Amaranthus retroflexus). They also occurred, although sparsely, elsewhere. Where the prairie was covered with thick stands of native forbs, now released from their usual competition with the grasses, or where annual weeds were present in abundance, it had the appearance of a weedy pasture. Here the percentage of remaining prairie sod was small.

\section{Increase of Certain Native Grasses}

Despite the drought and indeed as a result of it, certain native grasses had increased greatly. Sixweeks fescue (Festuca octoflora) had become abun- dant in the bare areas in eastern Nebraska and Kansas prairies. Its brown alternes covered the dead bodies of the former dominants. Westward the variety $F$. o. hirtella was so abundant that it had complete possession of various hilltops and slopes where the dominant grasses had died. The light, very abundant seed ripened in July and was broadcast widely by the high winds.

Buffalo grass (Buchloe dactyloides), in grassland bordering the mixed prairie, spread rapidly both by stolons and seed and thus increased its holdings. Seedlings of the very drought resistant blue grama (Bouteloua gracilis) thrived. They frequently grew from seed scattered down the hillsides, since this grass was locally common in the eastern prairies only on the ridges and driest upper slopes. The clumps and patches of established plants usually had remained intact even in places where all the little bluestem and most other grasses had died. The plants tillered profusely and covered much soil. Indeed, from them a new type or community of vegetation, nonexistent in predrought true prairie, had its origin. The spreading of short grass, however, was slow and restricted in comparison with the widespreading and rapid invasions of western wheat grass.

Agropyron smithii made the greatest increase of any native grass. Formerly confined to the thinner soils, saline areas, or greatly disturbed places westward and occurring only sparingly in the eastern prairies, it finally rose to first importance among the dominants and occupied fully one-half of the entire prairie area. Hence, it deserved careful consideration. It was entrenched at least in small patches in all of the disturbed prairies and had taken possession of extensive areas in others (Fig. 12). At first the stand was thin and the stems scattered, but soon it consolidated its holdings into dense vegetation with one to two thousand stems per square meter. In some prairies it covered one-third of the entire area often in great belts or alternes several rods wide.

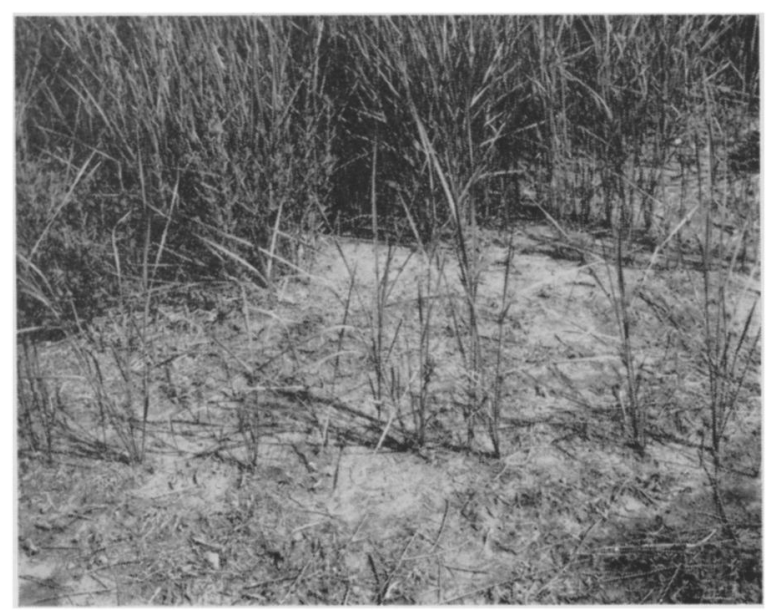

Fig. 12. Area in which big bluestem has died of drought being invaded by western wheat grass (Agropyron smithii). The lines of leafy stems indicate the position of the new rhizomes. 
In one it had complete possession of half the area and outposts were well entrenched in every square rod of the remaining half. It promptly populated portions of prairies overwhelmed by dust. Its vigorous growth in the bared or semibared places in early spring, and its migration by long, slender and branched rhizomes were distinct assets.

Thus, the year 1935 revealed not only the tremendous losses of a stabilized vegetation, the wide spreading of native forbs released from competition, the beginning of great invasions by weedy grasses and forbs, but also signs of recovery. Recovery was shown mostly by the slow spreading of drought resistant short grasses and especially by the extremely rapid invasion of wheat grass. But recovery was only intermittent through the following years, since drought again prevailed.

\section{RECURRENCE OF SEVERE DROUGHT}

The year 1936 was one of severe drought. The plant cover was open, nearly all upland vegetation was greatly dwarfed, and drought again took a very heavy toll. Western wheat grass and the short grasses, however, thrived. Wheat grass utilized the reserve of moisture in the soil following 1935, which, coupled with the moderate spring rainfall in 1936, promoted the continued spread of this drought evading grass. It greatly extended its territory in nearly all of the prairies. Blue grama is highly drought resistant and buffalo grass only slightly less so. These grasses thrived as long as any soil moisture was available, and extended their territory. It has been demonstrated experimentally that seedlings of these short grasses remain alive after all or nearly all other dominant prairie grasses have died (Mueller $\&$ Weaver 1942).

The following year was also one of drought although conditions were usually less severe than in 1936. The moist spring, however, was very favorable for the early-growing wheat grass. But the low summer rainfall and dry soil were extremely detrimental to late developing grasses. Moreover, the weedy annual grasses and forbs, which still grew thickly in the very open cover of perennials, rapidly reduced the water supply in spring and thus increased the intensity of drought. Big bluestem and other grasses already weakened by the past year of desiccation suffered further losses. Aside from the short grasses (blue grama and buffalo grass), needle grass and prairie dropseed probably suffered least among the dominants. Forbs decreased greatly; even the abundance of Aster multiflorus was considerably reduced.

Summarizing, these two dry years resulted in great advantage to wheat grass and the short grasses, since they thrived while their competitors waned. Short-lived annuals had increased both in species and abundance and had played an essential role in protecting the bared soil from erosion by wind and water. But the less xeric predrought vegetation had advanced but little beyond its stage of recovery at the end of 1935 (Robertson 1939). The next growing season, however, was one of good rainfall and there was marked improvement.

\section{RECOVERY IN 1938}

A year of approximately normal precipitation (1938) resulted in an excellent growth of vegetation, a great increase in its amount, and the production by most species of a large crop of seed. The growth of wheat grass was greatly accelerated. It extended its dominance even more widely and especially into places that had been vacated by the recent death of relict vegetation. By competition for water it suppressed many plants or fragments of communities left in the territory it had invaded. The patches and alternes of thriving short grasses, although usually still very open, became denser as an abundance of tillers and seedlings developed. In addition, buffalo grass spread by stolons.

Outside the wheat grass communities especially, there was in the aggregate much bare, unmulched soil left open for colonization. This varied greatly in the different prairies; in those most damaged onehalf to two-thirds of the soil was still unoccupied. The great quantities of decaying root material coupled with periods of humid weather in spring supported the growth of an unusually abundant and widespread population of fungi. The red stinkhorn (Simblum sphaerocephalum) was most abundant (Fig. 13). During the moist spring and early summer it was found widely and usually thickly distributed in nearly all of the prairies. Ten or more fruiting bodies per square meter were frequent on low ground, and often the air was foul with the nauseating odor produced by this saprophyte.

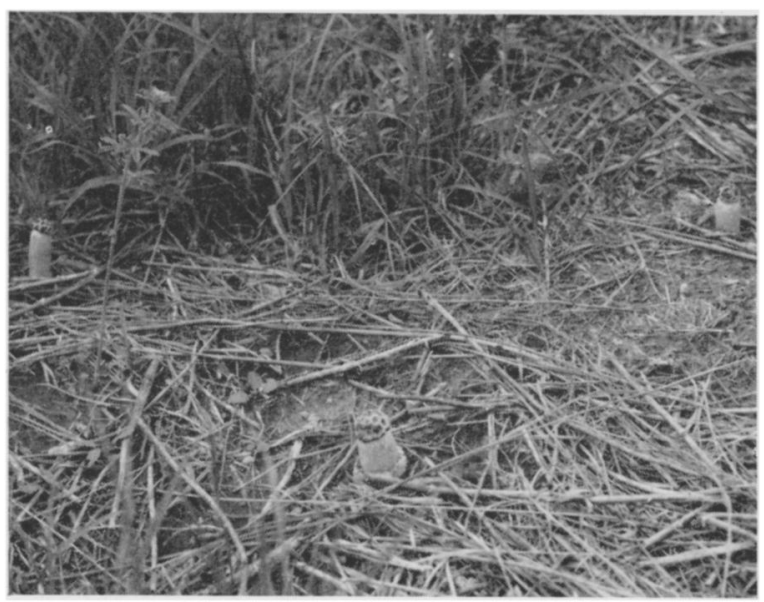

Fig. 13. Detail of bared soil at Crete, Neb., on May 22,1938 , showing abundance of fruits of the red stinkhorn (Simblum sphaerocephalum) which was thriving on decaying material in the moist soil.

The weedy stages of the subsere had nearly disappeared in many prairies and especially in those portions occupied by wheat grass. Aster and Erigeron had likewise greatly decreased. But in other prairies where the cover was less developed the foliage of 
Aster formed half the cover and Erigeron was so abundant that in June the prairies appeared at a distance as if covered with patches of snow (Fig. 14).

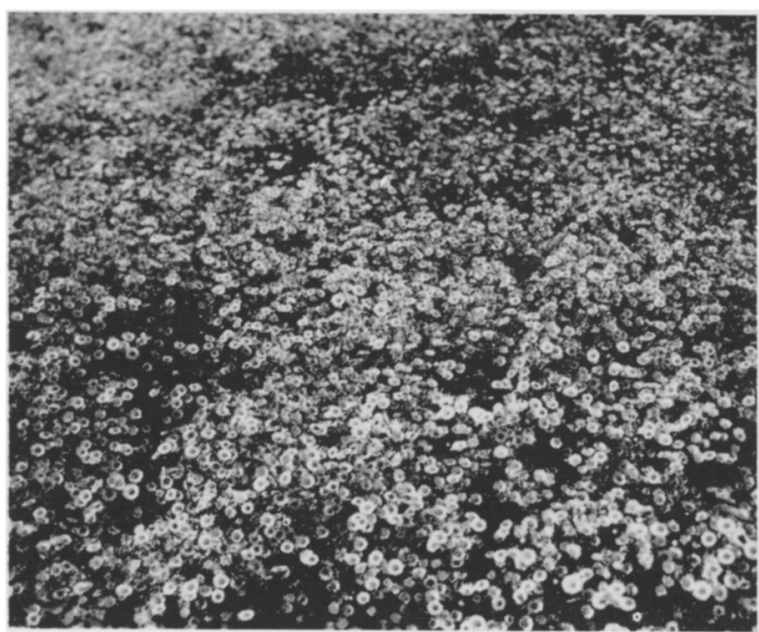

Fig. 14. Photo on June 20, 1938, in former bluestem prairie near Lincoln, Neb., of dense cover of daisy fleabane (Erigeron ramosus).

Extensive alternes of Festuca octoflora also prevailed. Had this grass been removed, many square rods of soil would have lost 95 per cent of their cover. Most native forbs were represented by only 15 to 20 per cent of their normal population.

The grasses that had withstood the two successive periods of intense drought made a good recovery. There was a considerable thickening of the vegetation resulting from the increased water content of soil. Big bluestem had leaves 2 to 3 times the normal width. Nearly all the grasses grew to an unusually large size and produced so much seed that it seemed each species was endeavoring to reclaim the entire area for its kind. Needle grass had scattered its seedlings widely and thus extended its original holdings in a remarkable manner. Prairie dropseed, also more drought resistant than the bluestems but less widely spread than needle grass, repopulated areas adjacent to the former stands of greatly thinned parent plants (Fig. 15). But many other native grasses were intermixed and these types were as yet only dimly defined. Big bluestem thickened its stand remarkably where it occurred in ravines and on lower slopes. Where it had remained on uplands, it promptly reclaimed much of the space made bare by the death of little bluestem and even on hilltops attained an unusually large size. Even little bluestem was slowly recovering. Thus, there was foreshadowed the reestablishment of former communities of vegetation.

June grass aided greatly in covering the soil with vegetation and side-oats grama (Bouteloua curtipendula) had spread widely in all but a few prairies and filled many of the interspaces between the other grasses. It is drought resistant; many bunches had persisted since 1935. Its rank growth and enormous production of seed was followed in 1939 by a marked wave of dominance which, un!ike that of wheat grass, was not long ma ntained. It was w.dely distr.buted in many wheat grass communities.

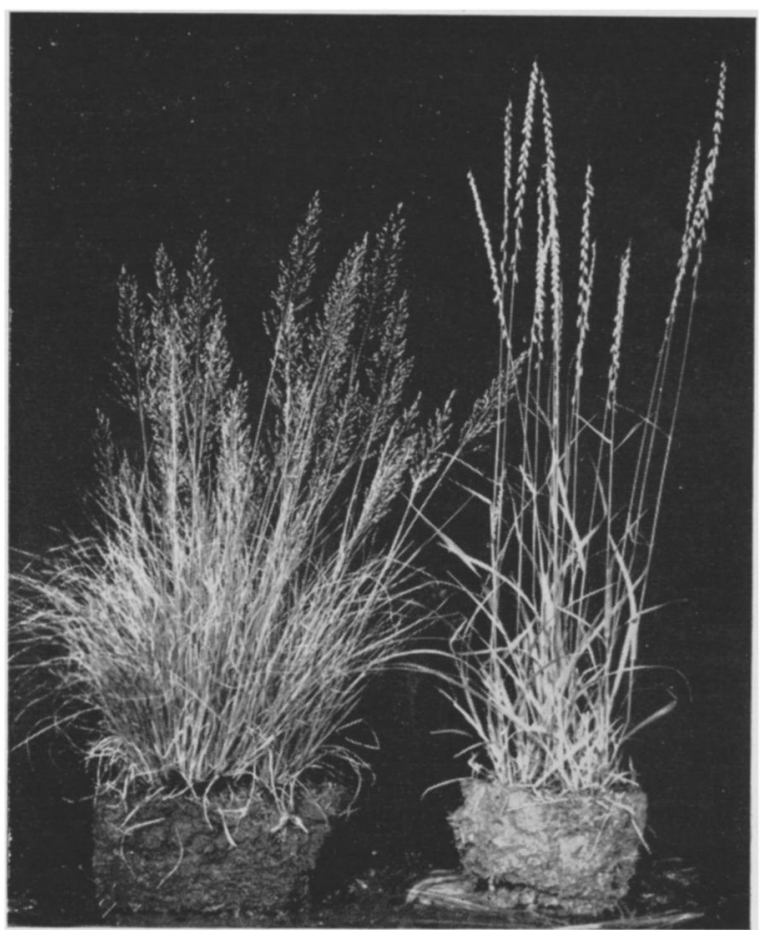

Fig. 15. Prairie dropseed (Sporobolus heterolepis) at left, and small bunch of side-oats grama (Bouteloua curtipendula). Both are drought resistant grasses. They seeded abundantly in 1938. Photo late in August.

The outstanding conditions in 1938 were a better to fairly complete occupation of the soil by grasses, although some were weedy annuals, and considerable reduction in bare ground. Most forbs that had increased were now greatly reduced or were being subdued, and ruderals were much less abundant. There was nearly everywhere a remarkable spread of big bluestem, side-oats grama and blue grama, and, in many prairies, of needle grass and prairie dropseed. This was in addition to the constant advances and consolidation of western wheat grass over much terrain. But in only a few prairies, notably at Belleville, Kansas, and Hebron, Nebraska, had the several types of vegetation become clearly and definitely defined (Weaver \& Darland 1944). This remarkable process was to be delayed by two more years of drought.

\section{DROUGHT OF 1939-40}

Early spring was dry in 1939; then followed a period of rainfall, but severe drought occurred in midsummer. Western wheat grass did not flourish. This was due in part to the unfavorable environment and perhaps partly to its remarkable growth and great seed production the preceding year. Moreover, wheat grass had to compete for water with an enormous stand of side-oats grama which was widely dis- 
tributed. There was an excellent early growth of other vegetation and the foliage cover became distinctly thicker. Although the forb population, including the weedy aster, gradually diminished, a remarkable repopulation of grasses had begun. Seedlings were plentiful, at least those of the more xeric grasses. Since the grasses were not closely grouped, competition for water was less severe than normally. Moreover, weeds were relatively few.

The enormous amount of side-oats grama, which grew to full stature and competed successfully with wheat grass, was an impressive sight. Indeed, it thrived as the wheat grass waned. It was often the most abundant species outside of wheat grass areas as well. But its dried leaves whitened the landscape in August and never again did it attain such prominence. Big bluestem likwise dried and lost its green color. It was badly damaged; much of it died in midsummer and nearly all green color disappeared from the landscape, so severe was the drought. But blue grama had increased greatly in early summer. It produced an abundant crop of seed and maintained its record of continuous gains, despite the deterioration of nearly all other vegetation.

A dry to moist spring, varying with location, and a dry summer characterized 1940, the last year of great desiccation. A lack of reserve moisture in early spring accentuated the drought. Wheat grass made good progress in invading the weakened relict vegetation or nearly bared areas resulting from its death. A vigorous growth of this sod-former occurred at all stations. It thickened its former stands and spread widely throughout the short grasses as well. In fact, in many prairies it had so nearly overwhelmed all other vegetation that only another year was needed to complete the change from true prairie to mixed prairie. This widely spread phenomenon resulted in part from the gradual building up of a short-grass understory to wheat grass or to the spreading of wheat grass into areas occupied by the constantly spreading blue grama and buffalo grass (Weaver 1943).

Losses of side-oats grama were very great. On some prairies all but 1 per cent had died by spring, except in lowlands where about 5 per cent remained intact. The dead plants formed an open, light-colored layer below the wheat grass. Nowhere did it thrive. A diseased condition, resembling mosaic, which became widespread caused the death of many plants, but most succumbed to fall and winter drought (Fowler \& Weaver 1940). Even the early blossoming needle grass failed to produce seed. Big bluestem attained a height of only 8 inches on low ground. By midsummer all the grasses were dry and discolored. They crunched underfoot like straw and would have burned readily. Annual yield was reduced to less than half normal (Weaver \& Albertson 1943).

This was the close of the long period of drought. It was followed by three years of nearly normal or above normal precipitation which kept the soil almost constantly moist. Rain also moistened the deep subsoil, most of which had been permanently dry for several years. Vegetation made a good recovery and the subsere of weedy grasses and forbs gradually gave way to the several communities of perennial grasses.

This ten-year period of great changes in grasslands may now be summarized:

Drought threatened

1933

Precipitation 7 inches below normal

Severe drought in mixed prairie westward

A year of great drought

1935

Approximately normal precipitation Extent of losses revealed

Spreading of certain native forbs

Invasion of ruderal forbs and grasses

Western wheat grass spread widely

Short grasses increased

\section{6-37}

Severe recurrent drought except early in spring Further losses of less xeric grasses and forbs

Abundance of annual weeds

Steady increase in amount of wheat grass

Short grasses increased

1938

Approximately normal precipitation

Continued spread of wheat grass and short grasses

General recovery and thickening of cover

Decrease in amount of bare soil

Fewer ruderals; decrease in native weedy forbs

1939

Moist spring and early summer; then severe drought Wave of side-oats grama; wheat grass waned

Short grasses increased

Vegetation suffered from desiccation

1940

A year of drought

Great losses of prairie relicts and side-oats grama

Wheat grass and short grasses possessed entire prairies Mixed prairie developed (1938-41)

1941-43

Normal to above normal precipitation

Great recovery

Other prairie types became well established

Cover increased; forbs slowly reappeared

\section{RECOVERY; DEVELOPMENT OF GRASSLAND TYPES}

With the recurrence of years of normal or above normal precipitation, vegetation recovered. At first the processes were slow, since deep dormancy often follows great drought, but later they became greatly accelerated. When the weedy native forbs had been subdued by the increasing population of grasses, when the annual grasses and weeds had been mostly replaced by perennial grasses, and when the dominant

1 The term type is used for brevity and in the same sense as community. It indicates no special ranking. The unit of vegetation which each type or community represents is indicated where it is described. 
species through competition had replaced the former interstitial ones, there crystallized out of the heterogeneous drought populations several very definite grassland communities or types. In fact, the western wheat grass type had grown steadily year by year almost from the beginning of drought. Likewise, the short grasses had migrated into new territory and gradually claimed it for themselves.

Other types were less clearly defined since dominants were much intermingled, and subdominant species such as side-oats grama and June grass at times played a leading role in repopulating the bared soil. Even in 1940, much soil was still open to invaders in some prairies, and many places were populated only thinly by individuals of a potential grassland type. But with better conditions for growth, all bared places were reclaimed. Competition sorted out the permanent dominants from the seral or temporary ones, and the boundaries of the communities in the mosaic of prairie patterns became quite definite.

In a few prairies this stage had been attained as early as 1938; in most it was reached only during 1941 ; and in some the process is not yet complete and portions of these prairies consist of mixed, unstabilized remnants of drought relicts.

In true prairies not entirely overwhelmed by western wheat grass, these types in 1940 were needle grass, prairie dropseed, and blue grama. Other common communities were the mixed prairie type, big bluestem type, relict big bluestem-little bluestem, and mixtures of several species without expression of dominance. These communities varied in size from a few square rods to many acres. One 15-acre prairie for example, which was mapped in detail, revealed 5 types each of which was dominated by a single species and 8 mixed types where two species in each were in definite control (Weaver \& Darland 1944).

\section{The Subsere}

A complete view of the methods and extent of recovery of vegetation cannot be had without consideration of the early and intermediate stages of the subsere. This includes a study of the early annuals, of native forbs which survived and increased, and of ruderal forbs and grasses.

\section{EARLY AN NUALS}

The Iowa prairies that suffered some damage were repaired rather promptly by a spreading of stiff tickseed (Coreopsis palmata), many-flowered aster, and prairie dropseed. Scarcely any annuals appeared. But west of the Missouri River immediately following the 1934 drought, there occurred a great scourge of annual grasses. The most abundant of these were six-weeks fescue, chess, and little barley (Hordeum pusillum). These were nature's shock troops which temporarily held the bared soil against the forces of erosion. During the earlier years they frequently constituted the major portion of the vegetation, but as the prairie was reclaimed by long-lived species these annuals filled the remaining network of bared soil. Finally they became merely interstitial species or failed to reproduce.
When great bare areas occurred everywhere, when plants of the understory had disappeared, and when erosion by water and wind seemed imminent, great alternes of six-weeks fescue clothed the naked soil. The density and extent of these stands were astounding. Bunches consisting of 20 to 30 stems growing out of the dead crowns of little bluestem were found regularly. Two hundred such aggregations of stems in a single square meter were common. Frequently dense stands with plants 20 inches high alternated sharply with bare soil. Festuca furnished only a temporary living cover. But even after it dried and lodged it protected the bared soil from sun, wind, and flood (Fig. 16). Also when the prairie had been mowed, the stem bases were so numerous-often 100 per square inch-that they greatly protected the soil. Enough seed to cover the whole area had not been produced and portions of the prairie remained unplanted. Festuca associated intimately with the greatly thinned stands and dwarfed individuals of all the grasses.

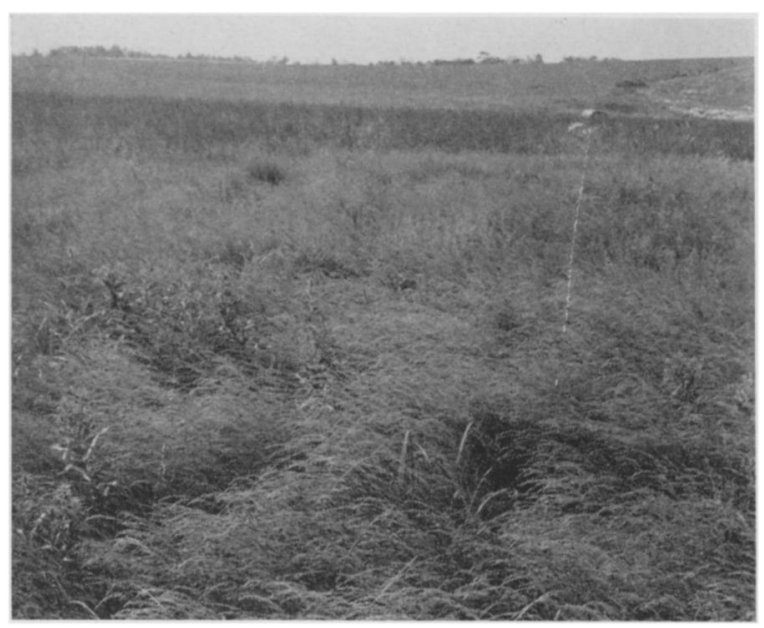

Fig. 16. Dense stand of the annual six-weeks fescue (Festuca octoflora) on June 24, 1935 . The dark background is western wheat grass.

Even after the severe drought in 1939, six-weeks fescue occurred in large amounts throughout the prairie. It is still abundant wherever small open places occur. So thick was the usual stand that the plants were ordinarily dwarfed to. a few inches in height, but they nearly always produced some seed. Whether living or dead, great numbers of this diminutive and slender grass formed a mulch which greatly accelerated water infiltration into the otherwise bare soil. The mulch also prevented rapid drying of the soil. Festuca is one of the few grasses that also occurred more or less regularly in the short-grass sod. Thus, six-weeks fescue was not only a seral dominant in the early years of drought but continued, although in decreasing abundance, throughout; finally, with the restoration of the grass cover, it was found only in the minor bare spaces. Of inestimable value in the recovery of prairie from disastrous losses, it 
is rapidly being relegated to its former place as a very minor grass.

Bromus secalinus (or closely related species) became abundant in grassland soon after 1934. This chess occurred in great amounts in the western part of the area where it frequently covered many acres in the drought-denuded grassland. Eastward, only local patches were common.

Little barley increased enormously and made green the landscape in places which would otherwise have been almost bare. Its role was similar to that of six-weeks fescue. Formerly of a great abundance and always increasing in amount on dry years, it finally filled only the smaller interspaces, instead of occurring as before in large patches or continuously over extensive areas. It still remains as a "filler" in open ground and regularly ocurs in association with the short grasses and in the understory of western wheat grass.

Certain native forbs became extremely abundant when the competing grasses were handicapped or overcome by the drought. Two of these, both of very minor significance in stabilized prairie, reached incredible numbers in 1935 and 1936. Both were annuals, Silene antirrhina and Specularia perfoliata. Seed was undoubtedly scattered everywhere by the wind, but the source of so much seed especially from these rather infrequently occurring species has never been determined. Since the seeds of both species are as small as specks of dust, they may have been blown long distances. The catchfly occurred widely and was found in all but a few of the most westerly prairies. In the bared areas the plants occurred in large numbers and often reached more than twice their usual stature. Neither again appeared in unusual numbers after the second dry year, 1936 .

More local but serious infestations of Tragopogon pratensis occurred during the early years of drought. Like the preceding species, this ruderal was found rather regularly over the eastern portions of the drought-opened prairie. In the thousands of small

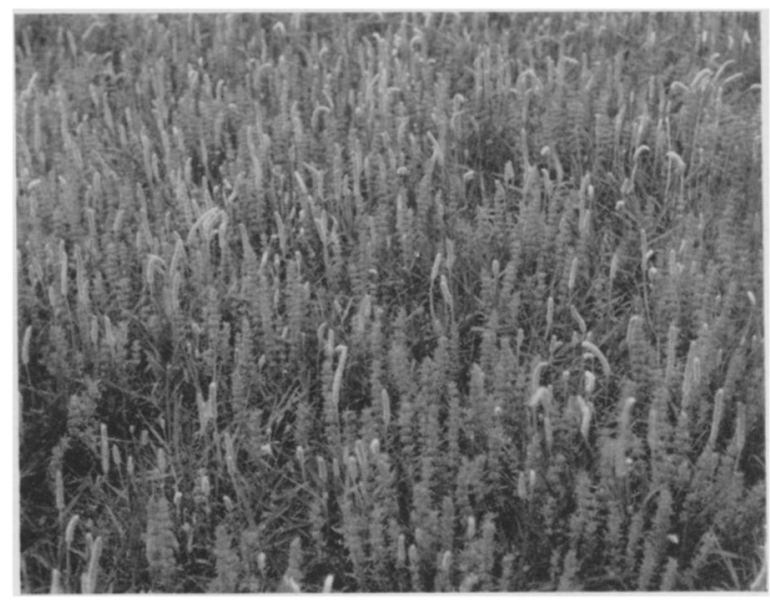

FIG. 17. Characteristic dense patch of Hedeoma his pida with Plantago purshii in prairie where other plants have died. Photo in June, 1937. bared places, which appeared to have been burned into the prairie cover, this coarse biennial was both abundant and conspicuous. In more continuously open places it grew in great masses.

A species of small stature and formerly found only associated with predrought short grass is Hedeoma hispida. When much dry, bare soil prevailed, this mixed-prairie mint became established very widely in all situations and was especially common in wheat grass. It has persisted, although in decreased abundance, and is still a widespread component of the several communities found in true prairie. Its seeds are light and easily distributed by the wind (Fig. 17).

\section{LONG-LIVED NATIVE FORBS}

The three chief longer-lived forbs that profited greatly by the death of their competitors and spread most widely were Aster multiflorus, Solidago glaberrima, and the winter annual, Erigeron ramosus. All three species ranked among the ten most widely distributed and abundant predrought forbs. They are composites with light, wind-blown seeds. Erigeron develops from rosettes; the others possess very abundant and efficient rhizomes by means of which they endured the drought.

Aster multiflorus (including A. batesii) spread widely until it constituted a dense, tangled, weedy growth over many acres. It did not occur in all of the prairies, but over considerable areas where drought had struck hard and wheat grass had not invaded it was practically the only species. The plants no longer formed bunches but a more or less uniform stand. It became so abundant that within a short time it ruined many of the prairies or large portions of them for the production of hay, because of its brush-like growth. So numerous were the plants and so low was the light intensity in their deep shade that any relict grasses were much attenuated and seedlings, even in good years, grew with difficulty. At first it seemed that it might dominate many prairies, and it did maintain its rise to importance for several years. The plants normally attained a height of 1.5 to over 2 feet. As a result, considerable native sod was broken because of the seriousness of this pest. Of course, it did protect the soil.

Many-flowered aster gave way rather readily to invading wheat grass. At Carleton, for example, where large bared areas were occupied by uniform stands of this forb in 1935-36, it decreased greatly in 1937-38 as wheat grass spread. By 1940 it had vanished. In many other prairies it diminished in amount in 1937 and rapidly after 1938. But even during the dry year of 1939, approximately onethird of the land in some of the worst infested prairies had more aster than grasses. Plants with 50 or more woody stems from a basal diameter of 6 inches reached a height of 18 inches and had a spread of tops of 2.5 feet. These were often closely spaced. But more frequently the more open type prevailed with 1 to 4 stems in a place and rather widely spaced on the rhizomes. In all prairies it became greatly suppressed by 1942 . In a few, however, it was repre- 
sented by large patches until 1943. With increased competition from the thickening stand of grasses, especially after 1942, the stands were further th:nned.

Solidago glaberrima became a grassland weed sometimes as widely spread as the aster. Blossoming at a height of 30 inches (in 1935) it appeared throughout some prairies either as a continuous, compact society or a series of isolated smaller ones. The dense patches resulting from extension of the rhizomes could best be evaluated in July in years with enough rainfall to promote flower production. The densest stands grew where the soil had been most bared. Its behavior was very similar to that of Aster but it was not so widespread either locally or over the region as a whole.

Erigeron remosus made such an enormous increase in so many of the true prairie areas (mostly eastward) that it was an outstanding feature during the entire drought period. The plants were not only abundant but of greatly increased stature. Over many acres of bared soil plants 2.5 to 3 feet in height were grouped so closely that their inflorescences formed a continuous pattern (Fig. 18). Over even wider areas, in patches of perhaps 30 to 60 acres, they filled the numerous interspaces between the remaining bunches and mats of relict grasses. Although the amount of daisy fleabane gradually decreased as the perennial grasses came back, it still maintained great abundance in 1938-40. Its numbers varied greatly, however. Since it had to start anew each year, with decrease of open spaces in the sod it has returned nearly to predrought abundance. Its rosettes were frequent in wheat grass, the stature and seed production depending upon water content in spring and early summer.

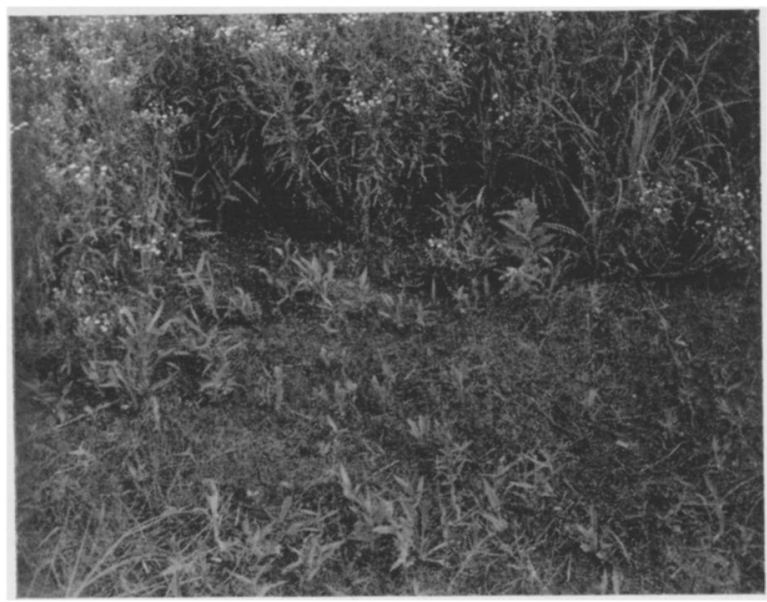

Fig. 18. Typical open space in prairie with dense growth of Erigeron ramosus in background. Note relict big bluestem and lead plant on the right and rosettes of daisy fleabane in the foreground. June, 1938.

The wide distribution and dense aggregation of certain forbs with large storage organs first became marked during the moist spring of 1938. They were formerly of relatively small abundance and little importance in stabilized prairie. Chief among them were violet wood-sorrel (Ionoxulis violacea), spiderwort (Tradescantia bracteata), windflower (Anemone caroliniana), and wild onion (Allium mutabile). They formed dense patches a few square feet to many square yards in area; in fact, with the continuing drought their numbers constantly increased and they were also found in many new locations (Fig. 19).

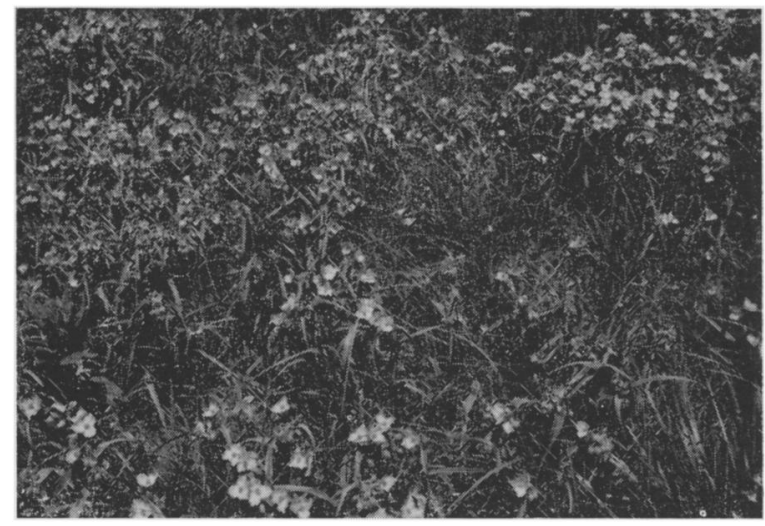

Fig. 19. Characteristic dense stand of spiderwort (Tradescantia bracteata) in June near Jamaica, Neb. This species profited greatly by the opening of the prairie sod.

Societies of closely spaced wild onion occupied many acres of low, normally wet land. Where as many as 200 scapes with flowers occurred per square meter, little grass remained. Ionoxalis and Anemone, especially, were associated with the invading wheat grass and often formed a layer beneath it. All are still abundant but they are being reduced in amount with the establishment of a denser prairie cover.

Other native forbs that increased greatly in certain prairies but usually only early in the dry cycle were Senecio plattensis, Artemisia gnaphalodes, Achillea occidentalis, all perennials, and the biennial Gaura parviflora.

\section{RUDERAL FORBS AND GRASSES}

Among the ruderals, Lepidium densiflorum spread like a scourge in 1936-37 from the Missouri River to the Rocky Mountains. Dense patches of small size to great extent occurred in the bared soil. This weed was often 14 inches tall with widely spreading crowns so closely spaced that the soil was nearly obscured. But with the wet spring of 1938, it almost vanished. It recurred later, but in greatly reduced amounts, especially in the more westerly prairies. But elsewhere it was mostly confined to local areas greatly disturbed by dust deposits.

Pursh's plantain (Plantago purshii) also profited by the open soil and for a time greatly increased. But like the annual horseweed (Leptilon canadense) it varied greatly from spring to spring, depending upon the conditions for growth. The small plants were usually greatly aggregated. They ripened seed early, and were thus well fitted to escape drought. In general, the plantain decreased rather early. Leptilon was prominent until 1938, when it practically 
disappeared from the prairies but only to become abundant again in the more open ones with a continuation of drought. Indeed, it occup:ed a few bared places as late as 1942 .

Various brome grasses, in addition to Bromus secalinus, played an important part in establishing a temporary cover. B. tectorum entered certain prairies in small amounts in 1935 and had spread lightly over many by 1936 (Fig. 20). In others it was only locally abundant as a colonist along with Pursh's plantain. Its abundance was somewhat proportional to the amount of bared ground. Where brome grass of any species grew thickly and seedlings of other grasses occurred, they were always attenuated. Even the bunches of June grass had very slender stems with a minimum of foliage. The flower stalks were much fewer, more elongated, and the spikes small as a result of the shade. In some great patches downy brome formed an extremely dense cover and was finally ousted by wheat grass or recovering bluestems only in 1943.

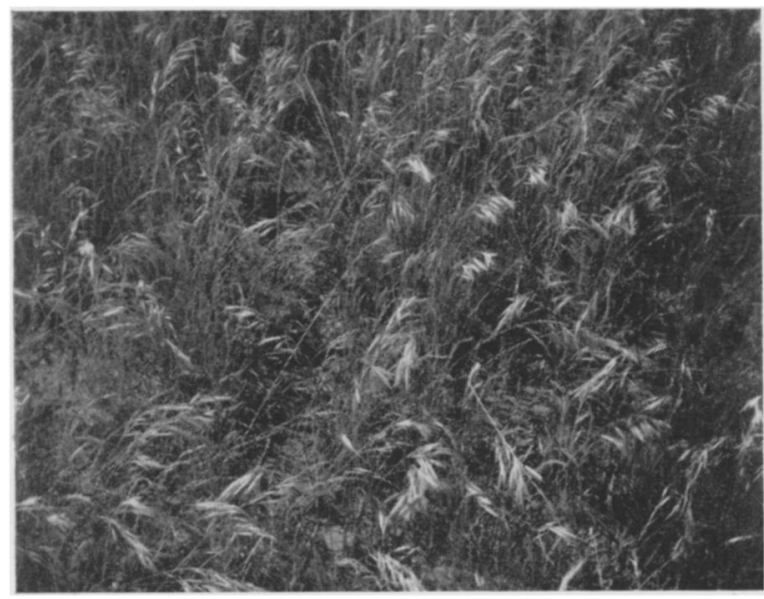

Fig. 20. Downy brome (Bromus tectorum) in a prairie near Nelson, Neb., where it covered several acres of drought-bared soil. Photo in June, 1937.

The enormous amounts of water absorbed and transpired by Bromus tectorum are indicated by the following experiment. On March 27, 1943, three square tubs with a total surface area of 7.15 square feet were partially filled with moist potting soil. Sods were cut 4 inches deep from dense stands of Bromus tectorum where it grew thickly in a pasture. The plants were green but only 1 to 2 inches tall. The sod was placed firmly on the soil in the tubs and packed very tightly in such a manner that the soil surface was an inch below the rim of the tub. The tubs were then weighed and placed with others on planks laid on the bluegrass sod in a lawn. A frame was built around the tubs to protect the sides from sunshine. The plants grew during the rather cool but dry, sunny spring until May 8. They were weighed every 10 days and watered as necessary, about once each week, to maintain the original weight. The amount of water received directly from rainfall was measured by means of a rain guage placed near the tubs. Thus, a record was secured of total water lost by transpiration plus evaporation from the surface soil.

The stand was very dense. The plants were 11 inches tall and beginning to bloom at the end of the experiment. They were then used to determine the amount of rainfall interception. This was accomplished by weighing a wire basket of the same area as a tub. The basket was made of fine-meshed woven wire so that when the thickly growing plants were cut off at the ground line they could be placed in an erect position in the basket. The weight of the wet basket (i.e., thoroughly sprinkled with water) plus that of the freshly cut plants was quickly ascertained. Water was then sprayed on the plants and basket for about 5 minutes. They thus became thoroughly wet, as after a rain. As soon as dripping from the basket ceased (in about 5 minutes) the weight of the wet basket plus the wet plants was determined.

It was found that 42.1 pounds of water had been lost per square foot from the plants and soil during their 42 days of growth. The amount of water held after a single wetting was .81 pound per square foot. The great density of the stand has been mentioned. Probably downy bromegrass never grows so thickly continuously over an entire acre. But under the conditions of this experiment the water loss per acre was 917 tons. Interception of rainfall totaled more than 17.6 tons per acre from the single thorough wetting. These data are indicative of the enormous amounts of water lost from the soil through transpiration by this weed, since under such a thick cover evaporation from the soil surface must have been small. It also indicates that large amounts of water are lost to the soil by interception, that is the rain water is held by the plants until it is evaporated and does not reach the soil. For example, Clark (1937, 1940) has shown that "when an inch of water falls during an hour, buffalo grass intercepts over 28 tons per acre, while prairie composed chiefly of big bluestem may intercept as much as 53 tons per acre."

Bromus japonicus occurred more locally, sometimes intermixed with other bromes, but frequently in dense stands. In one large, dust-covered, lowland area at Clay Center, for example, its dense shade and early use of available water so completely weakened the widely spaced bunches of bluestems, side-oats grama, and other natives species that they did not recover. Even after drying and lodging its smothering effect was pronounced. Finally wheat grass invaded and the brome grass decreased.

After 1938, hairy chess (Bromus commutatus) was found in most of the prairies. In bare soil it grew thickly, but was thinly scattered elsewhere. It did not fill the smaller bare places in the same degree as six-weeks fescue. It occurred sparingly if at all in well consolidated stands of wheat grass, in fact large patches of this weed were completely replaced by the sod-forming perennial in 1942 and 1943. Nor was it plentiful in stands of big bluestem except where they were open. Indeed, by 1943 it had almost disappeared 
or at least was found sparingly in most prairies.

During the later years of drought and the early ones of recovery, hairy chess was usually scattered thickly in alternes of the short grasses, although with the closing of the cover it had disappeared elsewhere. After early ripening and drying its presence clearly demarked, even from a considerable distance, the extent of the blue grama and buffalo grass which it overtopped.

In 1943 a dense growth of hairy chess occurred in nearly all types of vegetation, including needle grass and wheat grass, but not relict prairie areas where the cover was closed and normal prairie conditions prevailed. In early May when wheat grass was 8 inches tall, the dead autumnal growth of the brome was 1.5 inches deep and the dense stand of living plants grew 1.5 inches above it. The brome had grown not only around the bunches of needle grass, prairie dropseed, and others, but in them as well. It also grew thickly in wheat grass sod (Fig. 21). This was the condition in a 125 -acre prairie near Crete and it also prevailed generally, except in vegetation that had become very dense. The dead bases and gray-green tops of the living plants gave a drab tone to the whole landscape. It formed a soft cushionlike mulch which thoroughly covered the soil. The amount of air-dried dead and living brome grass was about 22 grams per square foot or more than a ton per acre. Later observations showed that the weed did not attain a height greater than 9 to 12 inches, and only 4 to 5 inches under wheat grass. The plants nearly all dried without producing flower stalks.

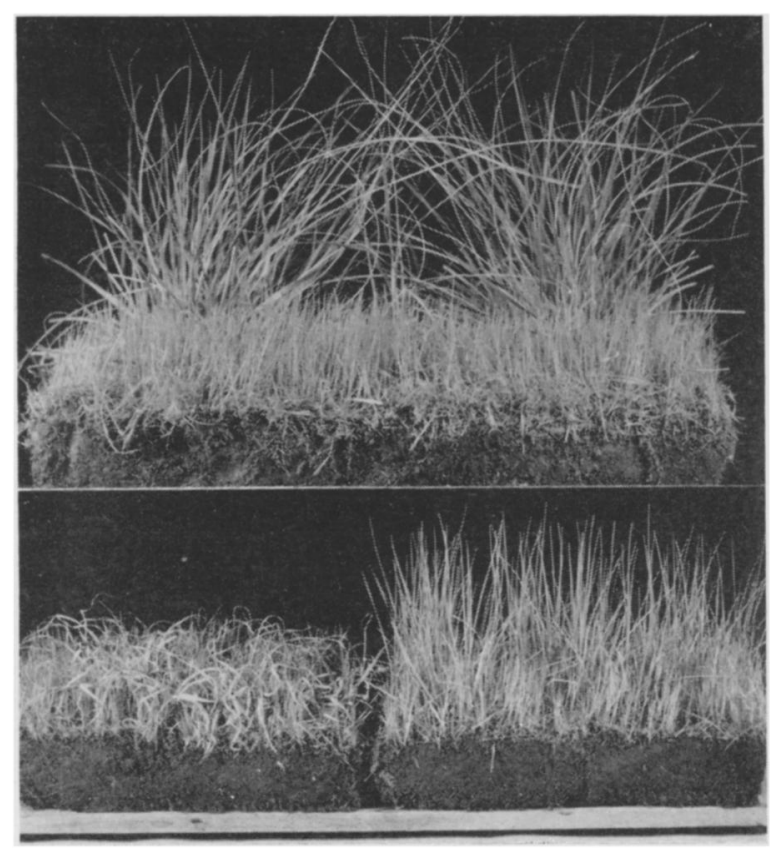

Fig. 21. Dense stand of hairy chess (Bromus commutatus) 3 inches high near Crete, Neb., on May 1, 1943. It formed a layer under needle grass (above), under the new growth of wheat grass (lower right), and equaled in height the old leaves of side-oats grama (lower left).
Their presence had little harmful effect upon perennial grasses which flourished and developed exceedingly well during this good year.

Certain prairies, in fact some parts of nearly all of them, were covered early with a thin to thick layer of dust blown from adjacent fields. Where the grasses were smothered or greatly harmed a large number of ruderals invaded. One of the most widespread was the Russian thistle, Salsola pestifer. In the early years of drought it was confined mostly to the western prairies. Later this weed thrived everywhere during the driest years, even on wind-eroded soil. But it decreased during those with cold wet springs, and also as a new cover of grass developed.

Lamb's quarters (Chenopodium album) and rough pigweed (Amaranthus retroflexus) demarked rich, loose soil by their dense stands and rank growth. Isolated plants or small groups of plants were also scattered widely. Annual sunflower (Helianthus annuus) was not uncommon in the weed stage of succession in greatly denuded grassland.

Witchgrass (Panicum capillare), green foxtail (Setaria viridis), and lovegrass (Eragrostis cilianensis) were all more or less abundant in the dust-drifted and otherwise bared places.

Often lack of much competition in the rich soil resulted in very good development of these weeds. In some local areas dust was deposited after a stand of wheat grass had developed. Such places were havens for many weedy species and from these centers seed was carried into other openings in the prairie cover. Here they grew rankly, except on the driest years, and gave the grasslands a very ragged appearance. Indeed, they could have been mistaken by the casual observer for weedy pastures or even weedy fields (Fig. 22).

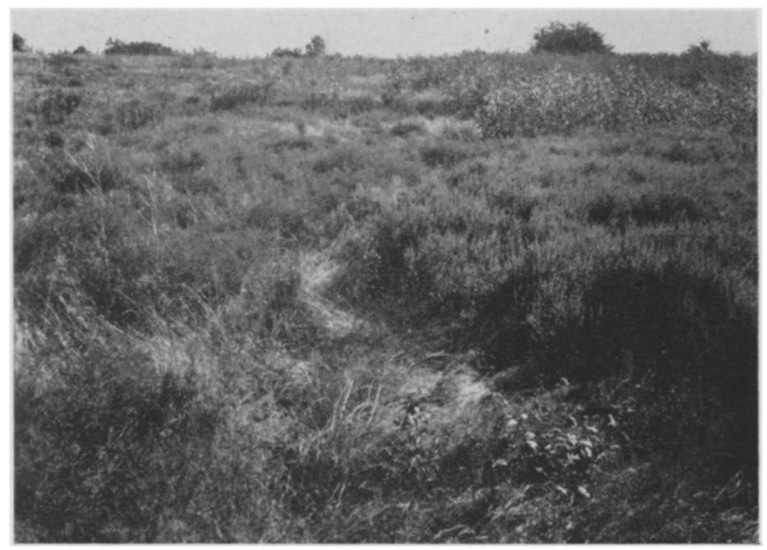

FIG. 22. Dust-covered bluestem prairie near Jamaica, Neb., that is thickly populated with weeds. Among these are perennial ragweed (Ambrosia psilostachya), annual sunflower, and lamb's quarters. It had received wind-blown dust during two or more years. In places the dust layer was 4 inches thick. Photo Sept. 15, 1943.

In summarizing the role of native species, they may be considered in groups (Table 2). The first includes only 6 forbs and a grass, which at once in- 
creased mightily as if selected by nature to ameliorate the condition of loss of cover. The role of Festuca octoflora, of Aster, Erigeron, and Solidago, so briefly and incompletely described, is worthy of deep and careful consideration by all students of grassland. They, with the annual and ephemeral silene antirrhina, Specularia perfoliata, and Hedeoma hispida, spread over the land, protected the soil, and contributed their dead remains to the formation of a new mulch. The importance of the following group which had the great advantage of abundant underground food accumulation has not been evaluated.

TABLE 2. Relict grasses and forbs that greatly increased during drought, and chief ruderals occurring in the subsere.

\begin{tabular}{|c|c|c|}
\hline \multirow[b]{2}{*}{$\begin{array}{c}\text { Forbs and grasses } \\
\text { native to true prairie }\end{array}$} & \multicolumn{2}{|c|}{ Ruderals in True Prairie } \\
\hline & $\begin{array}{c}\text { Of wide } \\
\text { distribution }\end{array}$ & $\begin{array}{l}\text { Locally common but } \\
\text { irregularly distributed }\end{array}$ \\
\hline $\begin{array}{l}\text { Festuca octoflora } \\
\text { Aster multiflorus } \\
\text { Erigeron ramosus } \\
\text { Solidago glaberrima } \\
\text { Silene antirrhina } \\
\text { Specularia perfoliata } \\
\text { Hedeoma hispida } \\
\\
\text { Ionoxalis violacea } \\
\text { Anemone caroliniana } \\
\text { Tradescantia bracteata } \\
\text { Allium mutabile } \\
\\
\text { Achillea occidentalis } \\
\text { Artemisia gnaphalodes } \\
\text { Gaura parviflora } \\
\text { Senecio plattensis }\end{array}$ & $\begin{array}{l}\text { Bromus secalinus } \\
\text { Hordeum pusillum } \\
\text { Tragopogon pratensis } \\
\text { Lepidium densiflorum } \\
\text { Leptilon canadense } \\
\text { Plantago purshii } \\
\text { Bromus tectorum } \\
\text { Bromus japonicus } \\
\text { Bromus commutatus } \\
\text { Amaranthus retroflexus } \\
\text { Chenopodium album } \\
\text { Eragrostis cilianensis } \\
\text { Erigeron annuus } \\
\text { Helianthus annuus } \\
\text { Panicum capillare } \\
\text { Salsola pestifer } \\
\text { Setaria viridis } \\
\text { Sporobolus cryptandrus }\end{array}$ & $\begin{array}{l}\text { Acnida tamariscina } \\
\text { Ambrosia trifida } \\
\text { Bursa bursa pastoris } \\
\text { Chamaesyce maculata } \\
\text { Echinochloa crusgalli } \\
\text { Lactuca scariola } \\
\text { Polygonum aviculare } \\
\text { Polygonum } \\
\text { pennsylvanicum } \\
\text { Solanum rostratum }\end{array}$ \\
\hline
\end{tabular}

From the early entrance and tremendous development of stands of Bromus secalinus and other weeds in the list to Plantago purshii, inclusive, much protection has been afforded the relict prairie species. They have been protected from direct insolation, from the removal of the soil about them by high winds and torrential showers, and they have benefited from additional water infiltration resulting from the presence, alive or dead, of the cover of weeds (cf. Weaver \& Albertson 1943). Likewise, Bromus tectorum and later arriving brome grasses and other species of this life-form served through the long years of the terrible drought in place of the protecting cover of native grasses, or with the returning cover, to preserve the soil. Even the presence of weedy forbs had its effect upon reestablishment of the prairie grasses. Sometimes this was harmful, as in exhausting the water supply and the utilization of too large a portion of the light; often it was beneficial in shading the grass seedlings, stilling the wind, warding off beating rains, and furnishing a protecting cover of debris. Destruction of the accumulated cover by fire as a means of weed control greatly retarded recovery. It removed the shade, decreased water infiltration, promoted runoff, and was thus especially detrimental to the drought-weakened plants.
Thousands of exposed and dormant crowns died, and seedlings succumbed to the heat of the fire or consequent conditions. Mowing the half-grown weeds and leaving them as a mulch on the soil would have promoted recovery.

The only places where a complete subsere from bare soil to perennial grass occurred were in portions of prairies so deeply covered with dust as to smother all vegetation. Here annual weeds were soon replaced by western wheat grass. Other areas nearly all had some relict climax grasses or at least some that recovered from dormancy. No prairie was entirely destroyed. Since the openings in the cover were of variable size, and source of seed of species in the subsere varied greatly, stages of development were consequently different. Neither were the stages nor the seral dominants of a stage identical in different portions of the region. Moreover, stages in recovery did not occur in a similar time sequence in the several prairies but varied greatly with local rainfall. Good years hastened recovery, very dry ones retarded it or actually returned vegetation to an earlier stage.

The manner in which even the most aggressive species yielded to the dominant grasses, once they were reestablished and good rains came, was of outstanding interest. During the long years of drought several prairie grasses of secondary importance increased greatly. For a time some held very high rank. But once most of the soil was reclaimed they decreased to more nearly normal proportions as the several climax or temporary climax dominants established control in their respective types.

\section{Needle Grass Type}

\section{(Stipa spartea Consociation)}

The stands of needle grass were greatly thinned at the inception of drought. But by 1938 this species, in addition to holding all of its original territory, had spread widely. At Nebraska City in southeastern Nebraska, for example, a great ridge extended across a 160-acre prairie. Formerly only the northern crest of the ridge was dominated by needle grass. But in 1938 a community of Stipa of great extent, with the single dominant furnishing 90 to 98 per cent of the grass cover, occupied not only the hill crest but extended far down the slopes where it had replaced the bluestems. But in other prairies where its original holdings were smaller, invasions were less rapid.

Near Lincoln, Nebraska, in 1938, on hillsides where one-half to three-fourths of the soil had been left bare, needle grass was common in open patches and as widely spaced individuals among the dead crowns of little bluestem. The old, relict bunches of needle grass were easily distinguishable from the smaller ones of recent origin. Many were protected by a thin stand of many-flowered aster. Otherwise the chief protection to seedlings was patches of six-weeks fescue. In the Pleasant Dale prairie this condition prevailed over most of the long, southwest slope of a hill for a distance of half a mile. Here 20 to 25 bunches of Stipa per square meter with a basal 
diameter of 1 to 6 inches were common. At Crete, Nebraska, somewhat similar conditions occurred over an area of 20 acres on the south- and west-facing slopes and top of a great hill. Formerly only a small portion was claimed by needle grass.

A continuous spreading of this species has taken place into semibared areas regardless of slope, and even onto low ground formerly covered by big bluestem (Fig. 23). Here it found during the drought years a dry warm soil, similar to its usual predrought home on uplands. Its early growth in spring and rapid absorption of the meager available water supply together with its early seeding habit aided greatly its development during the years with a moist spring and a dry summer. It greatly handicapped the growth of later awakening species which grew in the invaded territory. During almost every year of the drought, needle grass produced some seed. The large size and deep burial of the fruit, due to the twisting awn, insured germination even when the surface soil was dry. Except on the driest years, seedlings were common and establishment fairly certain. A good growth of widely spaced individuals occurred in 1939 and on other moderately dry years, since there was little competition for water.

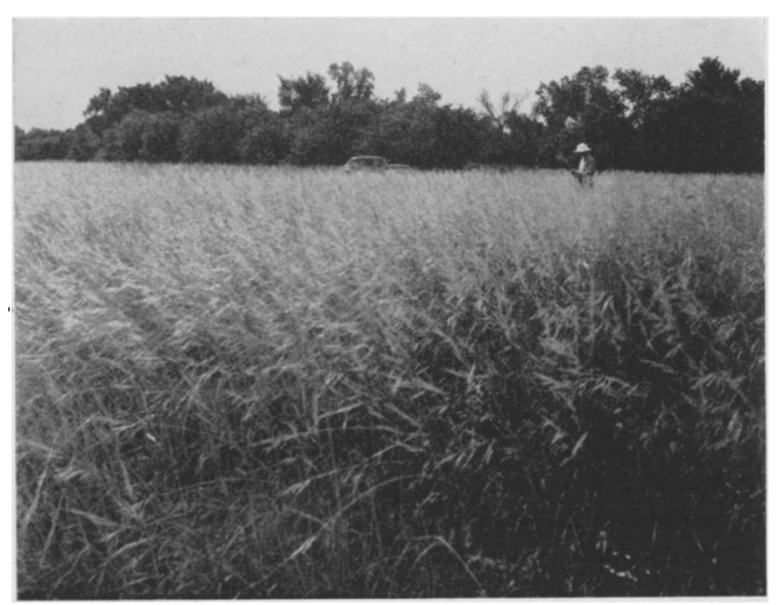

Fig. 23. Spread of needle grass (Stipa spartea) onto low ground along Salt Creek near Jamaica, Neb. It had replaced big bluestem and other lowland grasses. Photo in June, 1943.

By 1941 the great production of foliage even of widely spaced plants resulted in partially shading the soil. Enormous seed crops were produced and myriads of seedlings, sometimes as many as 20 per square foot (Fig. 24). Thus, communities of Stipa possessed plants of all ages from seedlings of the current year to old bunches 5 or more inches in basal diameter. As many as 50 to 60 small bunches, one or two large ones, and numerous seedlings per square meter were common in certain prairies even as early as the good year 1938. This condition now maintains widely. In fact, the stand of needle grass, which is often 80 to 90 per cent pure, has thickened and the plants matured until it now appears as a climax. The soil mulch has been restored and characteristic spe- cies of the understory are gradually reappearing. June grass, Scribner's panic grass, and other plants common to the community are present and, in fact, the entire plant cover is approaching stabilization. Stabilization is not complete, but at least the dominants are so firmly entrenched that the community may remain as such for many generations.

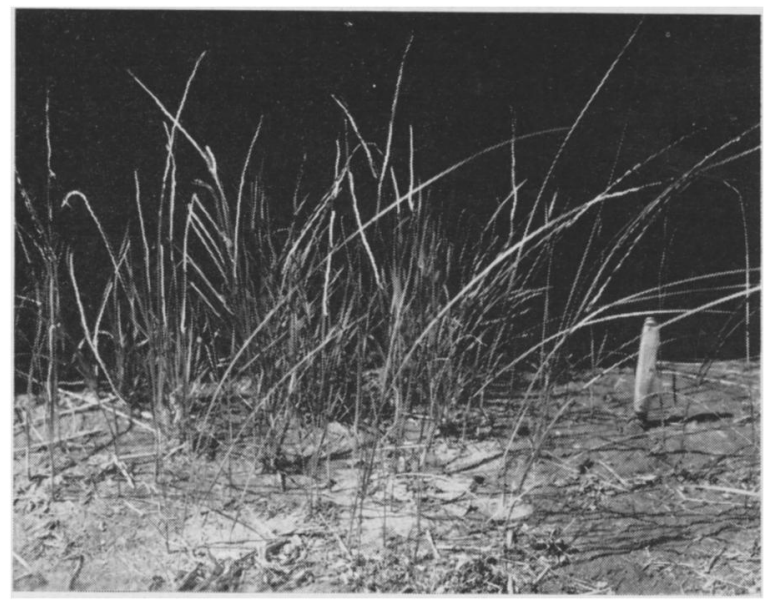

Fig. 24. Seedlings of needle grass in nearly bare interspaces between established bunches near Woodlawn, Neb., in June, 1943. They averaged about 12 per square foot. Some grasses have been clipped.

A field of fruiting Stipa is a magnificent sight (Fig. 25). The tall, wand-like stems are often so thick, as they bend gracefully under the weight of the seed, and the foliage cover so dense that the general appearance, until one separates the crowns, is that of a sod-former rather than a bunch grass. Actually the basal cover is very small, only about 13 per cent, but in newly populated places it is greater. After the fall of the seed the four-foot stems, now bleached white, become erect. They and the broad, shiny glumes remain for several weeks and clearly demark the boundaries of the needle grass community.

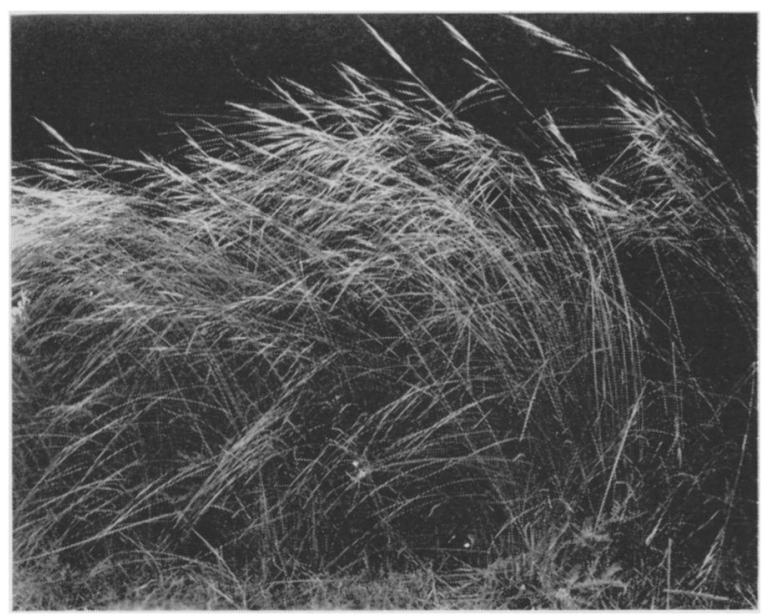

Fig. 25. Needle grass near Pleasant Dale, Neb., heavily laden with seed on June 20, 1943. This is a typical climax stand. The stems are 3.5 to 4 feet tall. 
The spread of needle grass during the dry cycle has been so great, from hilltop to lower slope (where it sometimes contacts the shrubs) and onto flood plains, that this type is surpassed in area only by western wheat grass and big bluestem (Fig. 26). This maintains despite the fact that Stipa does not occur in several of the southwestern prairies and only sparingly in that area.

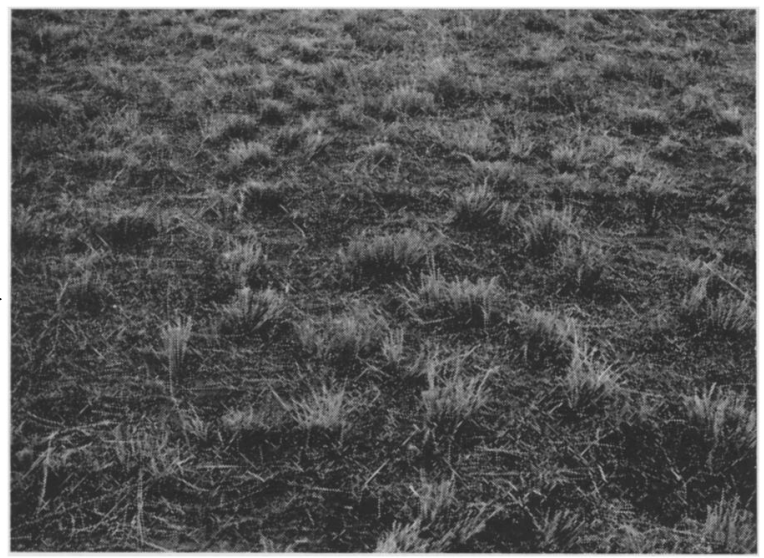

Fig. 26. New stand of mowed Stipa spartea in fall, 1940 , on portion of a prairie near Lincoln which formerly had none, but was clothed with little bluestem in 1934.

\section{Prairie Dropseed Type}

(Sporobolus heterolepis Consociation)

Prairie dropseed was formerly of such small importance that its communities held sixth place in predrought true prairie. After the first impact of drought it was thinned even more greatly than needle grass. But it recovered without loss of territory and benefited greatly by the death of its competitors and consequent opening of new territory for invasion. Cessation of mowing, because of very little forage production during the driest years, permitted this late-blooming bunch grass to ripen abundant seed (Fig. 27). Seedlings became established over many

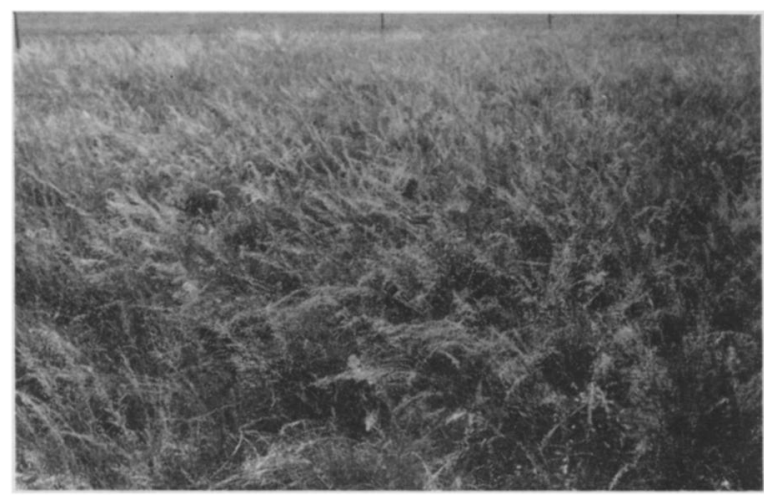

Fig. 27. Prairie dropseed (Sporobolus heterolepis) protected from mowing at Lincoln. It had replaced little bluestem and was producing a large crop of seed. Photo Sept. 29, 1940. acres adjacent to old stands and developed into new bunches. This enormously increased the territory occupied by this type. In more easterly grasslands especially, the prairie dropseed community occurs regularly.

Older, widely spaced bunches attained a diameter of 12 to more than 18 inches and a foliage height of 1.5 to 2 feet. The narrow greenish-yellow leaves curved gracefully outward and downward in summer and in winter lodged thickly in such a manner as to provide a mulch to a distance of 10 to 14 inches around the base of the plant. Formerly prairie dropseed shared the drier uplands with needle grass. Like needle grass it spread down the slopes, often to the edge of ravines. The myriads of seedlings established during the better years of the drought rapidly grew into tufts and these into bunches. Once a good stand was attained, other grasses and forbs had difficulty in becoming established. It often stabilized its communities after 1941, almost to the exclusion of other species. But elsewhere more scattered individuals constitute an important component of a mixed type of vegetation.

\section{Western Wheat Grass Type \\ (Agropyron smithii Consociation)}

The early appearance of Agropyron smithii immediately following 1934, its wide distribution and tremendous abundance as well as its remarkably successful competition with other species during the dry period have been very impressive (Weaver \& Hansen 1941; Weaver 1942) (Fig. 28). In 1939, Weaver and Albertson stated that "extensive earlier surveys showed clearly that western wheat grass, al. though a dominant of other portions of the true prairie, notably the hardlands of the Dakotas, constituted scarcely any part of this association in the central prairie region. It occurred along roadways, occupied the compacted soil by the sides of trails through the

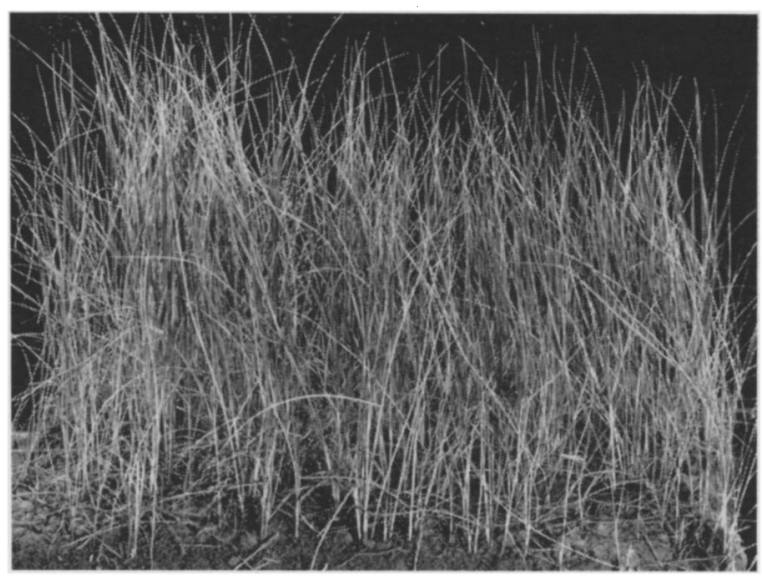

Fig. 28. Typical thick stand of well established wheat grass, 18 inches tall, on June 25, 1937. Note the lack of blossoming on this dry year and the characteristic absence of litter on the bare soil. Under such stands true prairie species were robbed of their rightful water supply and died. 
prairie, and was found in abundance locally where a shallow claypan made conditions unfavorable for the growth of the usual dominants. Occasionally a few stems were found about disturbances such as gopher mounds. In native pastures, centers of infestation often occurred on knolls or about gateways where cattle or horses congregated and trampled the soil while stamping to free themselves of flies."

It had increased in these places during the relatively dry years of 1932-33 and produced an abundance of seed. Moreover, about its centers of infection in bluestem prairie there may have been rhizomes that produced few and relatively inconspicuous culms. When drought laid bare much prairie soil and great storms filled the air with dust, these high winds undoubtedly carried the wheat grass seed as well along the bared surfaces. Almost always where layers and drifts of dust were formed, wheat grass was the early occupant. Unlike most other grasses, seed of wheat grass will germinate and the seedlings become established even when it is covered with two inches of soil. Sod may produce new stems when buried 12 inches deep (Mueller 1941). Rodents and certain other animals also played a part in seed distribution. From countless local centers of infestation, wheat grass migrated outward by long rhizomes and formed circular areas a few feet to a few rods in diameter. Where these were surrounded by stands of prairie grass they did not increase in size (Fig. 29). Likewise, long narrow belts of wheat grass around the brows of hills indicated where early drought was most severe. Often whole hillsides were covered with pure stands of this grass, and many lowlands became a continuous area of undulating wheat grass stems.

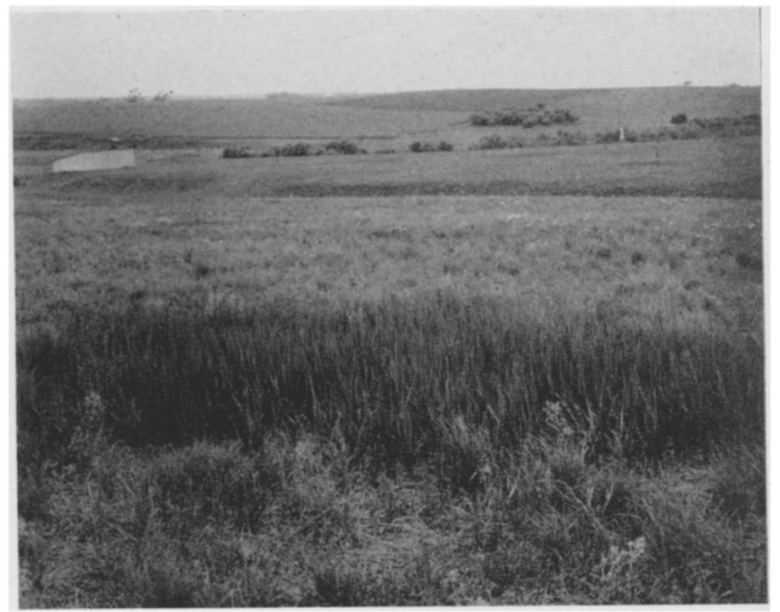

Fig. 29. Small outpost of western wheat grass in prairie near Crete, Neb., on May 22, 1938. Plants were 2 years old and the stand was moderately dense. Grasses near it were fairly well intact and the wheat grass had not spread farther by 1943 .

Invasion was well advanced during the early years of drought. When good rains came in 1938, wheat grass extended outward rapidly along the periphery of its established communities as well as into neigh- boring ones not yet stabilized. Successful invasion of undisturbed true prairie has never been observed, but the method of invading relict prairie vegetation has been studied in detail. The rhizomes are extended between the remaining plants but rarely through their crowns. The first year stems within the newly invaded area occurred singly or in twos or threes and were widely spaced. Forward progress was rapid but such gains were not consolidated until a second season of growth. Then the stems became aggregated and the territory well occupied. These marginal belts of advancing wheat grass were usually several yards wide. Indeed, the advance into new territory with a greater water supply was demarked by the greater stature, increased production of foliage, and more numerous flower stalks than in soil already occupied.

A good development of wheat grass, as pointed out elsewhere (Weaver 1943), is dependent upon available soil moisture in spring and early summer. Since there was usually little reserve water in the soil during the years of drought, wheat grass in its early and rapid growth often exhausted all or nearly all of the available supply of water before later awakening prairie grasses and forbs had made much growth. This resulted in the successful competition of wheat grass and in the dwarfing and finally the death of most other species (Fig. 30). This dwarfing effect was often pronounced even among the most deeply rooted forbs, plants regularly being reduced to one-half or less of their normal size (Weaver 1942). There was very little competition for light, since even under a good stand of wheat grass about 80 per cent of full sunshine reached the soil surface. Few seedlings of any kind were ever found in established wheat grass. Any ruderals in an invaded area

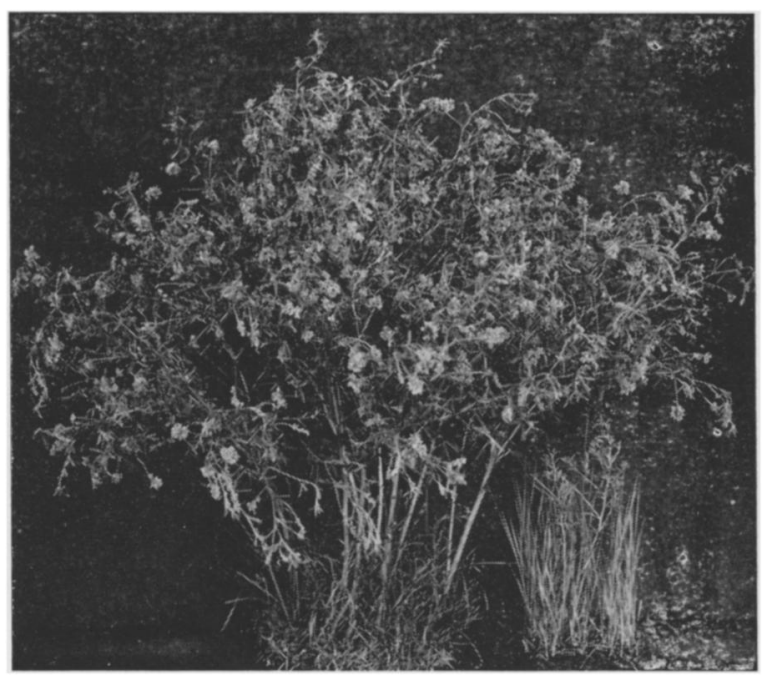

Fig. 30. Two plants of Psoralea foribunda from a prairie near Lincoln on June 28, 1943. The competitors of the plant on the left, which is 30 inches tall, were bluestems. Plant on the right, taken only a few feet distant but from an equally large rootcrown, was 12 inches tall. It had been surrounded for several years by western wheat grass. 
were soon suppressed and died. Exceptions were Hordeum pusillum and weedy species of Bromus. Festuca octoflora and Erigeron ramosus are likewise annuals with periods of growth similar to those of wheat grass. Any others were incidental and of very minor significance, such as Hedeoma hispida and Specularia perfoliata. They shared the late fall and early spring moisture with the wheat grass.

Relict forbs were almost entirely those with deeply penetrating root systems-characteristically leadplant (Amorpha canescens), blazing star (Liatris punctata), prairie rose (Rosa arkansana), and false prairie boneset (Kuhnia glutinosa). These were dwarfed immediately after the wheat grass invasion. With a gradual depletion of subsoil moisture, which was not replaced by current rainfall, they became fewer and fewer and mostly disappeared. This occurred even on low ground.

Relict little bluestem was easily overcome by wheat grass and during all of the years with severe summer drought any relict big bluestem was dwarfed and usually dried by midsummer. Despite the occasional less severe years, as 1935 and 1938, big bluestem and practically all other grasses were finally overcome, except in areas where wheat grass had not invaded. Hence, in spring the pure stands of wheat grass presented a clean, dark-green, monotonous landscape. Only after 1941 was there much debris on the soil.

\section{YIELD OF WHEAT GRASS IN COMPARISON WITH BIG BLUESTEM}

One of the outstanding changes in bluestem prairie which had been replaced by western wheat grass was a decrease in plant production. An extensive study of relative yields of grasses in these two types was made in 1943. It included not only the annual yield but also yields when the erop was removed two or more times during the growing season. The plots were selected in pairs and in such a manner that one of wheat grass and one of bluestem were in close proximity. Usually they were separated by only a few feet and never by more than a few yards. The sample plots were circular and each was 20 square feet in area. The grasses were clipped 2 inches above the soil in order to simulate mowing. They were air-dried and weighed to the nearest gram. All yields except in the last Table (6) are expressed as average yields per plot.

TABle 3. Partial yields and total yields of western wheat grass harvested in seven plots in the Pleasant Dale prairie in 1943.

\begin{tabular}{c|c|c|c}
\hline \hline May 19 & June 28 & August 16 & Total \\
\cline { 1 - 2 } 142 & 93 & 67 & 302 \\
173 & 130 & 30 & 333 \\
155 & 118 & 144 & 417 \\
209 & 273 & 102 & 584 \\
133 & 257 & 51 & 441 \\
119 & 374 & 84 & 577 \\
214 & 159 & 66 & 439 \\
Av. 164 & 201 & 78 & 442 \\
\hline
\end{tabular}

A series of samples were taken on upland in the Pleasant Dale prairie on May 19, June 28, and August 16, with results as shown in Tables 3 and 4 .

On May 19 wheat grass was about 9 inches tall and in the fifth-leaf stage of development. Moisture had been plentiful. The grass soon recovered after being clipped and gave a larger yield on June 28, when it was about 13 inches tall and again in the fifth-leaf stage. Very little growth occurred thereafter since only a few stems made any recovery. The yield in August was due mostly to a slight intermixture of side-oats grama, a very little prairie dropseed, and a considerable sprinkling of big bluestem which had grown to a height of about 10 inches.

That early mowing had only slightly decreased the yield was shown by the fact that the single clipping on June 28 (Table 4) averaged 374 grams while the sum of the averages of two early clippings was 365 .

Table 4. Partial yields and total yields of western wheat grass (left) and big bluestem (right) when each was harvested twice from ten plots in 1943.

\begin{tabular}{c|c|c||c|c|c}
\hline \hline June 28 & Aug. 16 & Total & June 28 & Aug. 16 & Total \\
\hline 433 & 9 & 442 & 645 & 271 & 916 \\
360 & 24 & 384 & 745 & 467 & 1,212 \\
311 & 74 & 385 & 601 & 300 & 901 \\
343 & 52 & 395 & 620 & 205 & 825 \\
422 & 37 & 459 & 545 & 211 & 756 \\
365 & 99 & 464 & 592 & 270 & 562 \\
263 & 85 & 348 & 511 & 207 & 718 \\
408 & 47 & 455 & 539 & 172 & 711 \\
402 & 71 & 473 & 517 & 355 & 872 \\
430 & 93 & 523 & 563 & 312 & 875 \\
& & & & & \\
Av. 374 & 59 & 433 & 588 & 277 & 835 \\
& & & & & \\
\hline
\end{tabular}

Wheat grass clipped first on June 28 was 15 inches tall and in the sixth-leaf stage. Flower stalks had not developed. Yields in August were not from recovered wheat grass, only a little of which occurred in but one sample plot, but from the same kinds of grasses mentioned as occurring in the other plots. The yield of the nearly pure big bluestem, 18 inches tall at the first clipping, exceeded that of wheat grass. In fact, the yield of wheat grass was only 64 per cent of that of the bluestem. In August, big bluestem had a foliage height of 15 inches and numerous flower stalks 22 to 35 inches tall. The yield was about half that of June 28 (Table 4). The total yield of wheat grass was only 52 per cent as great as that of big bluestem.

When wheat grass in this prairie was harvested for the first time on August 16, its yield was somewhat less than the total of either two or three harvests of a similar stand (Table 5). This decrease seemed to be due to the suppression of any relict vegetation where the wheat grass grew uninterruptedly until August. Its total yield was 47 per cent of that of big bluestem. The bluestem at the time of harvest was 22 inches tall and possessed scattered flower stalks 30 to 40 inches higb 
TABLE 5. Yields in grams of western wheat grass and big bluestem harvested near Lincoln on August 16 and August 5, 1943, respectively.

\begin{tabular}{|c|c|c|c|}
\hline \multicolumn{2}{|c|}{ Pleasant Dale (upland) } & \multicolumn{2}{|c|}{ HAVELOCK (lowland) } \\
\hline Wheat grass & Big bluestem & Wheat grass & Big bluestem \\
\hline $\begin{array}{l}332 \\
368 \\
267 \\
347 \\
473 \\
476 \\
429 \\
391 \\
397 \\
368\end{array}$ & $\begin{array}{l}753 \\
758 \\
784 \\
771 \\
846 \\
903 \\
731 \\
979 \\
904 \\
794\end{array}$ & $\begin{array}{l}854 \\
658 \\
948 \\
601 \\
793 \\
768 \\
471 \\
707 \\
746 \\
693\end{array}$ & $\begin{array}{l}2,468 \\
2,239 \\
1,945 \\
2,955 \\
1,602 \\
1,963 \\
2,379 \\
2,196 \\
2,375 \\
2,410\end{array}$ \\
\hline Av. 385 & 822 & 724 & 2,253 \\
\hline
\end{tabular}

Relative production of wheat grass and big bluestem was also ascertained on lowland on the flood plain of Salt Creek near Havelock, a suburb of Lincoln. A magnificent prairie of big bluestem had become infested with Erigeron ramosus in patches and belts. This resulted from death of the bluestems by drought (Fig. 31). Small amounts of wheat grass spread through these and in a relatively few years replaced all but a few patches of relict big bluestem.

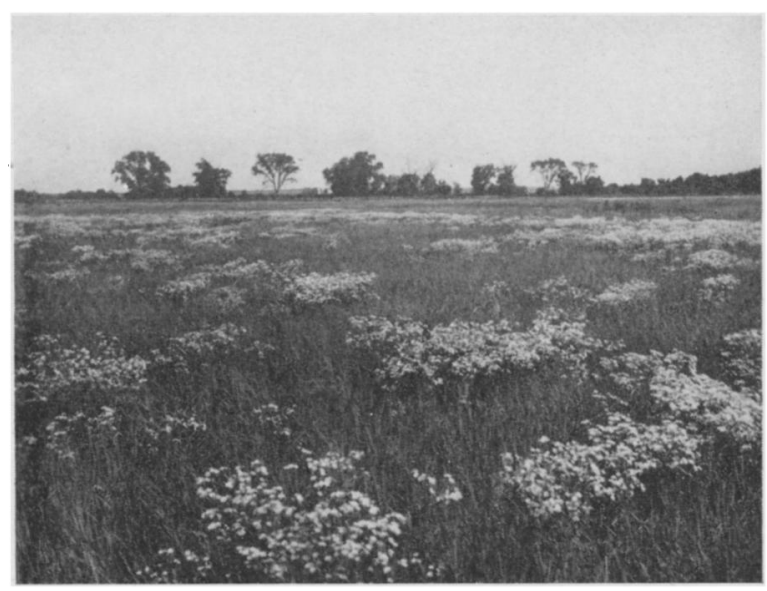

Fig. 31. Increase of daisy fleabane (Erigeron ramosus) in lowland big bluestem prairie following drought of 1934. Later wheat grass invaded and replaced nearly all of the big bluestem. Photo June 27, 1938.

On August 5, 1943, the wheat grass grew thickly in pure stands and to a height of 18 to 22 inches. There were a few flower stalks, 22 to 27 inches tall. It gave way abruptly to relict areas of big bluestem (Fig. 32). This grass was also almost pure but had a sparse understory of Kentucky bluegrass. The foliage was 30 to 32 inches tall. Flower stalks varied from few to abundant and ranged in height from 35 to 54 inches. In both types the stand was more open in a few of the pairs of samples. Yield of wheat grass was 88 per cent greater than that on upland but yield of big bluestem was about 2.7 times as great as that at Pleasant Dale. Thus, on this lowland yield of wheat grass was only 32 per cent as great as that of big bluestem.

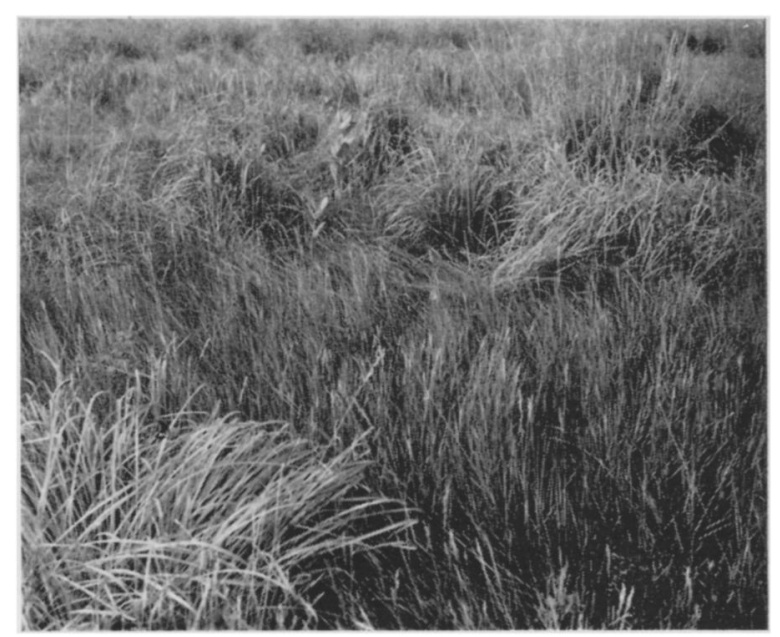

FIG. 32. Portion of the bluestem prairie in Figure 31 where relict patches of big bluestem remained in 1943. Wheat grass, about 20 inches tall (foreground), covered most of this level prairie. Big bluestem in the background and left foreground is about 30 inches high. Photo August 5.

At Carleton five sample plots were harvested on May 26 and again on August 17. Big bluestem had a foliage level of 28 inches. Flower stalks were numerous and about 40 inches high; inflorescences were appearing. The stand was dense and nearly pure. Foliage level of western wheat grass was 18 inches just outside the bluestem alternes, an average height that was regularly maintained throughout. Only a few scattered spikes occurred. The stand was uniformly good, but not dense. The early yield of wheat grass averaged 304 grams, the later one 106, and the total yield was 410 grams. Where two clippings were made, one on June 29 and another on August 17, the total yields were higher, 655 grams. Even this yield, however, was only 66 per cent as great as that of big bluestem (987 grams) clipped at the same time.

A single clipping of undisturbed wheat grass on August 17 yielded 686 grams, which was much higher than either of the preceding. But it was only 60 per cent as great as the yield of big bluestem (1,143 grams) also cut for the first time in August.

At Hebron, on August 17, big bluestem had an average height of 16 inches. There were no flower stalks. The stand was not so pure as that at Carleton since there was an intermixture of little bluestem and side-oats grama. As elsewhere, all samples were from the upland. Wheat grass was in the same condition as that at Carleton. Clippings from five plots yielded 339 grams of wheat grass on May 26, and 94 on August 17. Total yield was 433 grams. Where the first clipping was made on June 29 and the second on August 17, total yield increased to 594 grams. But it was less at each clipping than from equal 
areas of big bluestem, which yielded 847 and 99 grams, respectively, in May and June. Total yield was only 63 per cent as great as that of big bluestem.

In summarizing the data from the several stations for comparison, early yields where only 100 or 140 square feet were clipped are increased to yields from 200 square feet for purposes of direct comparison (Table 6).

TABLE 6. Total vields in grams of air dry wheat grass and big bluestem from 200 square feet at the several stations under different numbers of cuttings, and per cent yield of wheat grass compared with that of big bluestem.

\begin{tabular}{|c|c|c|c|c|c|c|}
\hline \multirow{2}{*}{$\begin{array}{l}\text { Station } \\
\begin{array}{l}\text { Pleasant } \\
\text { Dale }\end{array}\end{array}$} & \multicolumn{3}{|c|}{$\begin{array}{c}\text { Months } \\
\text { when clipped }\end{array}$} & \multirow{2}{*}{$\begin{array}{l}\begin{array}{l}\text { Wheat } \\
\text { grass }\end{array} \\
4,420 \\
4,328 \\
3,848\end{array}$} & \multirow{2}{*}{$\begin{array}{c}\begin{array}{c}\text { Big } \\
\text { bluestem }\end{array} \\
\\
8,348 \\
8,223\end{array}$} & \multirow{2}{*}{$\begin{array}{c}\text { Per cent } \\
\\
52 \\
47\end{array}$} \\
\hline & M & $\begin{array}{l}\mathrm{J} \\
\mathrm{J}\end{array}$ & $\begin{array}{l}\mathrm{A} \\
\mathrm{A} \\
\mathrm{A}\end{array}$ & & & \\
\hline $\begin{array}{l}\text { Havelock } \\
\text { (lowland) }\end{array}$ & & & A & 7,239 & 22,532 & 32 \\
\hline Carleton & M & $\mathrm{J}$ & $\begin{array}{l}\mathrm{A} \\
\mathrm{A} \\
\mathrm{A}\end{array}$ & $\begin{array}{l}4,100 \\
6,545 \\
6,855\end{array}$ & $\begin{array}{r}9,869 \\
11,425\end{array}$ & $\begin{array}{l}66 \\
60\end{array}$ \\
\hline Hebron & M & $\mathrm{J}$ & $\begin{array}{l}\mathrm{A} \\
\mathrm{A}\end{array}$ & $\begin{array}{l}4,334 \\
5,944\end{array}$ & 9,467 & 63 \\
\hline
\end{tabular}

From Table 6 it may be seen that in every comparison wheat grass yielded far less than big bluestem. It has been shown elsewhere (Weaver 1942) that water infiltration into soil covered with wheat grass was only 42 per cent as rapid as its entry into the same kind of soil covered with big bluestem. Hence, there is more water lost by runoff and evaporation. Soil under wheat grass has invariably been found drier than that under bluestem. This may account in part for the decrease in yield. Table 6 shows that yield from a single harvest was only 54 per cent as great as that of big bluestem on upland and only 32 per cent as much on low ground. Where one cutting was made in June and one in August, the average yield was only 60 per cent that of big bluestem.

Wheat grass is less palatable than most other grasses in true prairie, even including sand dropseed. Its early growth in spring and late development in fall does extend the length of the grazing period. But under normal conditions the same end is attained by growing Kentucky bluegrass. Soil under wheat grass tends to lose the good tilth it had when it was covered with big bluestem. For these reasons encouragement of the planting or growing of western wheat grass in true prairie is not in accord with the best grazing practice.

\section{Blue Grama Type}

(Bouteloua gracilis Consocies)

Blue grama is the most drought resistant of all the native grasses not only of true prairie but of the mixed prairie as well (Mueller \& Weaver 1942).
When it is known that it was present in small amounts in most prairies throughout the western portion of the area, one may well have predicted a great increase during a prolonged cycle of drought. Indeed, striking phenomena of the drought were the continuous spreading of blue grama from year to year almost without interruption from 1935 until 1942, and the large area occupied by this type when the drought finally terminated. It migrated into new territory immediately after 1934, since it was harmed the least of all grasses. It has been the most widely and most consistently represented by seedlings, especially seedlings that survived.

Blue grama has often survived where all other species died, and it has always been prompt in thickening its stands and thus consolidating its gains. It has not only enlarged most of its original small patches until they now cover many acres of uplands but also thousands of new outposts have been established. It is now found everywhere from hilltops to the lowest slopes. This grass has even carpeted the bottoms of ravines, and its location has little or no connection with topography. It became established wherever wind, water, or animals distributed seed in bare soil. Here its seedlings persisted when all others died. Bunches remained in some areas where wind and water had eroded the surface inch or two of soil and left them elevated above the general soil level. Blue grama sodded over the driest banks and elsewhere formed an understory, even under tall panic grass. The sod-mats resulted from the aggregating of numerous individuals. From these outposts any adjacent bare soil was populated, and seedlings became established everywhere in open spaces among any of the thinned relict grasses. Indeed, the seedlings are very tolerant of shade. Once blue grama is well established, it is only with difficulty that mid grasses are able to replace it.

Drought tolerance was marked. In 1940, when drought in June bleached white the wheat grass which did not revive with the July rains, the greenness of the understory of blue grama made a strikng contrast. Big bluestem was often entirely dried above ground while beside it blue grama was still green. It usually blossomed and set seed at some time during the summer when intermittent drought had prevented such activities of the mid grasses. Not uneommonly the abundant, dried flower stalks lightened the landscape in dry years in the blue grama type. There seemed to be a more or less constant supply of seed (Fig. $33)$.

When good rains finally came, blue grama seedlings occurred so thickly in many bare interspaces or on other unpopulated soil that the new growth had the appearance of a newly made lawn. In places the soil was thus entirely obscured. In many portions of prairies outside this short-grass type, it was possible to walk long distances and tread on!y on bunches or mats of blue grama, so widely and in such great numbers had the plants been distributed. An intimate intermixture of 10 to 40 per cent of blue grama with big bluestem or big bluestem and little bluestem, in 


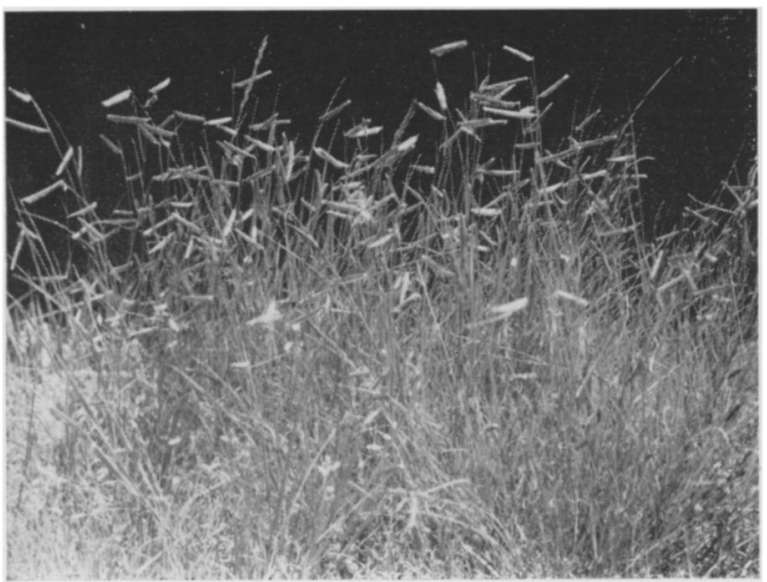

Fig. 33. Blue grama (Bouteloua gracilis) flowering on a dry year (1940) when most other grasses suffered severely from drought.

addition to distinctive alternes, was not uncommon. Thus, the history of blue grama has been one of constant gains. Only after two or more years of good rainfall has its possession been disputed by the bluestems.

As a result of the great drought the numerous irregularly shaped areas of blue grama occurred abundantly. Frequintiy these alternes were in direct contact with $b^{\prime} g$ b.uestem or small ones were often surrounded by this tall grass. Interspaces in the mats of short grass during the long period of drought were the home of numerous winter annuals. Chief among these were six-weeks fescue, little barley, downy brome, and chess. In fact, these weeds, with the oncoming of good rains, were scattered throughout the mats as well. Thus, short-grass communities could be distinguished at some distance from adjacent types by the light color of the early ripening and dried annual grasses.

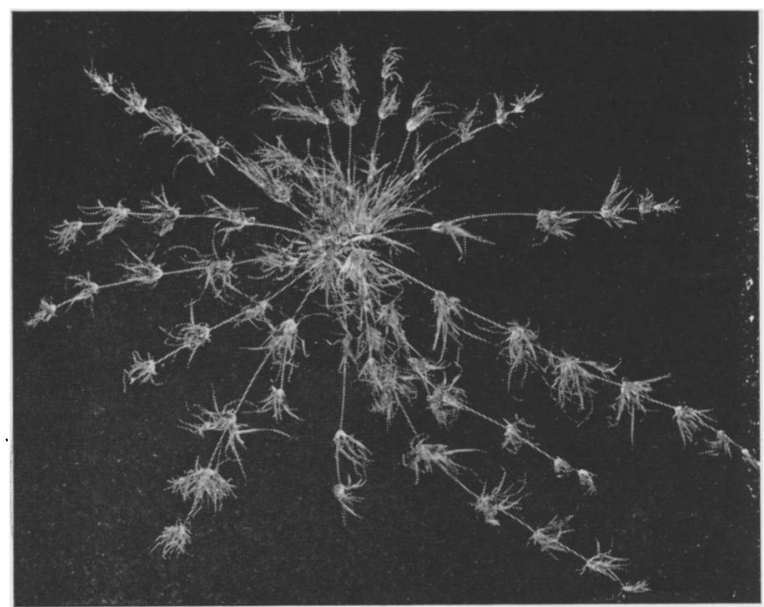

Fig. 34. Radial spread of buffalo grass (Buchloc dactyloides) in a pasture near Lincoln. From a crown only 1.5 inches in diameter in early spring of 1938 , stolons spread laterally a maximum distance of 15 inches by June 28 of the same year.
Buffalo grass was not only far less abundant than blue grama before 1934 but it also survived the drought much more poorly. Hence its part in recovery of prairie was far less important and will be included with the blue grama type. Upon the death of its mid grass competitors, it spread widely along the western fringe of true prairie. In overgrazed and trampled pasture it has increased tremendously, often clothing the soil with nearly pure stands (Fig. 34). In distribution, it ranged from the bottoms of ravines to the thinner upland soils. The great increase in number and total area of disclimax, shortgrass pastures nearly to the Missouri River in eastern Nebraska has been described (Weaver \& Hansen 1941).

In the few prairies where buffalo grass was well established before the drought, it gradually replaced its losses and increased slowly. After 1940, it made a good recovery under the increased rainfall and its stolons advanced several feet in a single season. It thus replaced an open basal cover with a closed one of 90 per cent or more, in addition to extending its territory. Nearly always associated with blue grama, the stolons threaded their way among the bunches of this grass and thus formed a dense, mixed sod. The pure and mixed stands of short grasses and the intermixtures of one or both of these species with bluestems were far surpassed in extent in their role as an understory to western wheat grass.

\section{Mixed Prairie Type}

(Eastward Encroachment of Mixed Prairie Association)

The replacement of bluestem true prairie by western wheat grass and short grasses, especially blue grama, and the later intermingling of the mid grass and short grasses to form mixed prairie has been described (Weaver 1943). The formation of the mixed type became clearly apparent in some grasslands in 1938 when an intermixing of wheat grass and short grasses along their numerous ecotones became pronounced. But even previous to this and synchronously with the early spreading of wheat grass, the short grasses had migrated into the bared areas also and established new holdings. At Belleville, Kansas, for example, mutual invasions by mid grass and short grasses had resulted by 1938 in very large areas of the Agropyron-Bouteloua mixed prairie type (Fig. 35).

Blue grama also established seedlings widely in places that had been invaded by wheat grass, especially during and after 1938. In fact, its seedlings (and those of buffalo grass over the limited region where it occurred) were practically the only ones, except side-oats grama, that became widely and generally established. They produced vigorous bunches which later often aggregated into an open sod. Competition for water, which they withstood, suppressed or killed nearly all other plants, both weeds and native species. Hence, mixed prairie consisted almost entirely of the pure layer of mid grass above and the short grass or grasses below. Conversely, wheat 


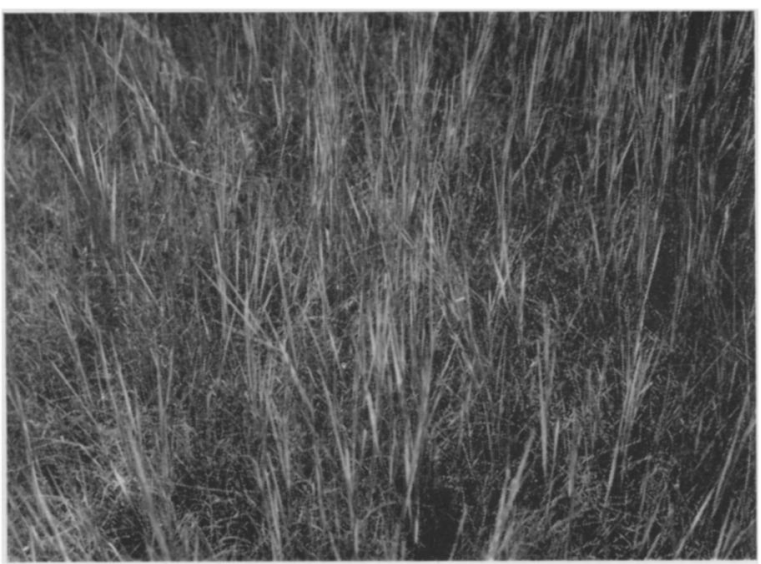

Fig. 35. Invasion of western wheat grass into buf falo grass and formation of mixed prairie. The short grass is about 6 inches high, the wheat grass about 28 inches. Photo Belleville, Kan., August 12, 1942.

grass was the only species that regularly invaded short grass, although side-oats grama was found in some prairies, often abundantly in the openings between the sod-mats before wheat grass invaded.

The rhizomes at first extended into the bare soil between the bunches or sodded mats but later spread thinly through them. This invasion into dense stands of buffalo grass was slower and seemed more difficult. Here the wheat grass stems were scattered widely in a thin stand. Aside from the short grasses, wheat grass usually spread only in open ground or where big bluestem or other grasses had been greatly thinned by drought or dust. Only once has wheat grass been observed invading stabilized bluestem prairie, and this proved unsuccessful. Neither was the needle grass community nor the prairie dropseed type successfully invaded. But the mutual invasion of short grasses and wheat grass has occurred in the western edge of true prairie throughout a belt 100 to 150 miles in width. In short-grass pastures, especially those in which stock was excluded for a time, wheat grass became very abundant and a mixed short grass-wheat grass type became established.

The period of invasion of both wheat grass and short grasses seems to be past, since practically all of the remaining prairie area is now occupied by other types of vegetation. Thus, there is much soil covered with pure wheat grass, where short grasses are not present, just as pure types of blue grama or mixed short grasses occur in prairies or portions of them where wheat grass is not found. But mixed prairie is most prevalent and this type is more extensive than any other single prairie type today, not excluding big bluestem. The intermixing of short grasses and wheat grass, however, has not terminated. Moreover, certain local areas once dominated by pure stands of wheat grass have not only been invaded by short grass but the wheat grass has been almost or entirely replaced by it. This was a process of gradually thinning the stand as the sod of short grass slowly became denser. As explained elsewhere
(Weaver \& Albertson 1943), blue grama has much finer roots than those of western wheat grass and they more thoroughly occupy the soil, especially the surface soil. Unlike wheat grass, blue grama grows vigorously at any time during the warm season, regardless of previous activity. Its flower stalks may develop, blossoms appear, and seeds ripen in only a few weeks.

Wheat grass in pure stands does not produce flower stalks and ripen seed every year despite good rainfall. In fact, little or no seed was produced anywhere in true prairie in 1943. The stand is often so thick that the plants appear sodbound. Sometimes the understory of blue grama presents a similar appearance. Wheat grass and the combination of the two grasses seem to overdraw on the water supply in their newly established communities. Their behavior and fate in true prairie during a series of years of normal precipitation are unknown. Despite the complete occupation of the land and the establishment of a good soil mulch, this type is not climax. Indeed, it should be emphasized that the present mosaic cover of the prairie after three years of nearly normal precipitation even where complete is not climax. Only the period of occupation of all of the territory by a number of different types of vegetation has been reached. A condition of stabilization has not been established and return to the predrought dynamic equilibrium of climax types will necessitate many changes.

\section{Big Bluestem Type \\ (Andropogon furcatus Consocies)}

Big bluestem developed as a distinet type in certain prairies in 1938. The community on upland resulted from the survival of this species wherever the bluestem type had lost its chief dominant, little bluestem, either by extreme drought or by dust coverage and drought. Because of its deeper roots and production of rhizomes, big bluestem often did survive, and when rains came it spread rapidly. This resulted in 1938 and 1941-42 in the apparent anomaly of a luxuriant growth of this tall grass in habitats so dry that the mid grass had succumbed. It survived the drought in the bunch habit, the rhizomes mostly being dormant, and only in 1938 (but in some upland prairies much later) did it become a sod former. With the coming of a series of good years (1941-43), big bluestem sometimes increased from a 10 per cent stand to form a cover that became 80 to 95 per cent as dense as that on low ground before the drought. Thus after 1942, many prairies when viewed at a distance in late summer or autumn showed great belts and patches, reddish brown in color, on hilltops and slopes where the flower stalks of big bluestem with their forked inflorescences grew thickly on the uplands (Fig. 36).

Other extensive areas of big bluestem survived the drought in part in ravines, on lower slopes, and on flat land supplied with run-in water. Here, unless at once invaded, it was later able to replace its losses and reestablish the original tall-grass type. 


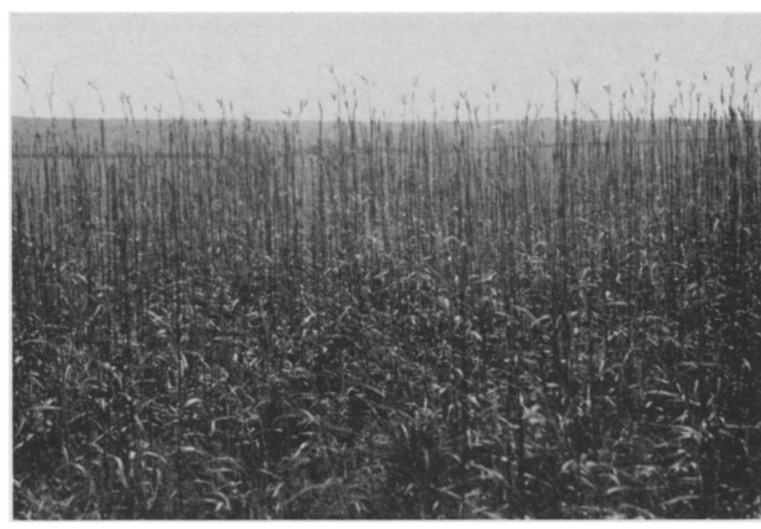

FIG. 36. Big bluestem (Andropogon furcatus) on a hilltop near Woodlawn, Neb., on August 10, 1943. In this nearly pure stand the foliage is about 30 inches high. Weeds along a fence a quarter of a mile distant form the line.

Quite in contrast to this outcome were the hundreds of places where the open stands of big bluestem wcre early invaded by wheat grass. Then the bluestem was nearly always dwarfed, later suppressed, and ultimately exterminated in its former home, mostly on uplands, but sometimes on lowlands as well. Many dry years were characterized by moist early spring. This promoted the growth of wheat grass which used so much of the available water that even the early growth of big bluestem was sparse. If the moist period continued a little longer, wheat grass produced seed and became dormant, bluestem wilted and dried after having used much of its accumulated food to develop half of a normal growth of foliage before being overtaken by droughtdrought so severe that it sometimes (1936-39) killed half of the weakened plants. Great alternes became fragmented; the following year only patches occurred, and finally wheat grass, aided by drought, overcame

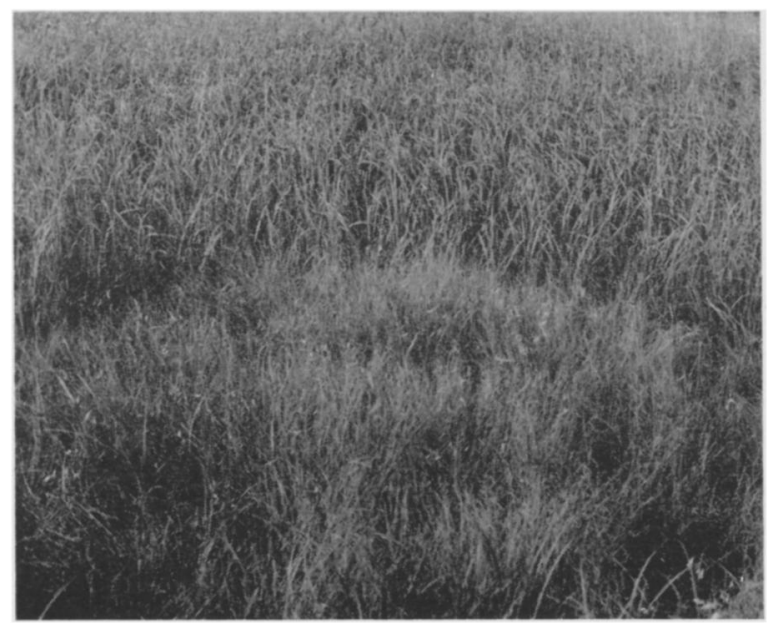

Fig. 37. Hilltop near Belleville, Kan., where little and big bluestem prairie has been replaced by blue grama in the foreground and a dense stand of big blue stem elsewhere. Photo July 15, 1938. even the hardiest and oldest survivors. That competition was the weapon of the invader was clearly shown by the better development and sometimes successful fruition of nearby stands of isolated plants where the wheat grass had not migrated (Fig. 37).

On both uplands and lowlands the new stands were sometimes intermixed in various degrees with other species-tall panic grass (Panicum virgatum), tall dropseed (Sporobolus asper), side-oats grama, western wheat grass and other grasses on low ground; and blue grama, side-oats grama, prairie dropseed and others on uplands. Where big bluestem is more abundant than all the others combined stability of the type with the continuation of good years seems assured. But in many places it occurs only as one of a considerable number of other grasses and often in about equal mixtures with them.

\section{Relict Big Bluestem-Little Bluestem Type (Modified Andropogon scoparius Consociation)}

The original upland cover of mixed little and big bluestem remained after the terrible drought in 1934 and 1936 only in small areas. The total amount of this type did not exceed 10 per cent in any of the 12 prairies selected for detailed study or in other prairies that were examined. In a few none of this original type remained. It is designated as the big bluestem-little bluestem type, since in most of these areas big bluestem was the more abundant at the end of the drought. Only in a few places does little bluestem even now (1943) comprise more than half of the vegetation, although formerly it often composed 80 per cent of the basal area. These relict areas were sometimes scarcely disturbed, as along old roads and trails where precipitation was supplemented by run-in water. In such places nearly pure stands of little bluestem may still survive. Elsewhere the bluestem grasses were only thinned and not destroyed. They maintained themselves as a community throughout the drought.

These communities varied greatly in size and distribution. They are the parts of the grassland least disturbed by invasion, and places where other species never became dominant, although sometimes as much as 80 per cent of the little bluestem succumbed. Since this species began to recover very tardily, and mostly not until 1941, although there was a good recovery in a few prairies in 1939 , the space it vacated was taken over mainly by the rapid spreading of big bluestem. But in part it was occupied by a remarkable increase of side-oats grama, and by June grass, and other native species formerly associated with the bluestems. These remnants of undisturbed or little modified grassland are found in all situations. They occur on north-facing slopes, often near their bases, and on low ground, especially where protection from desiccating winds was furnished by trees in ravines or along streams. But quite as often they were found on level hilltops, on east- or west-facing slopes and sometimes on the exposed south-facing ones as wellapparently wherever the water from rain or drifting 
snow had afforded enough moisture to keep the vegetation alive during the times of great heat, wind, and desiccation. These alternes and patches remained clearly demarked from other types of prairie (Fig. 38). They retained a good soil mulch, an understory of low growing grasses and forbs, and many other species that died elsewhere. Among these were Antennaria campestris, Astragalus crassicarpus,

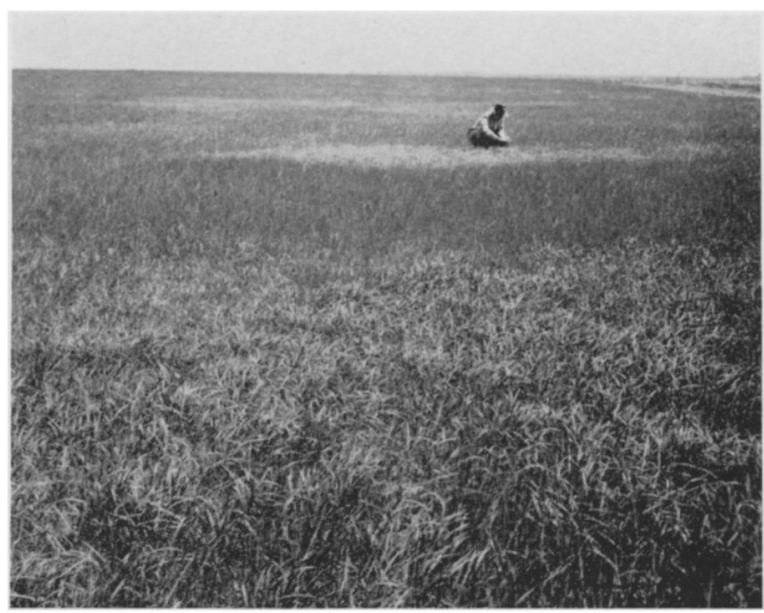

Fig. 38. Relict patches of big bluestem, light in color, in a prairie of western wheat grass near Carleton, Neb., on May 26, 1943. Bluestem is 8 inches tall and wheat grass about 13 .

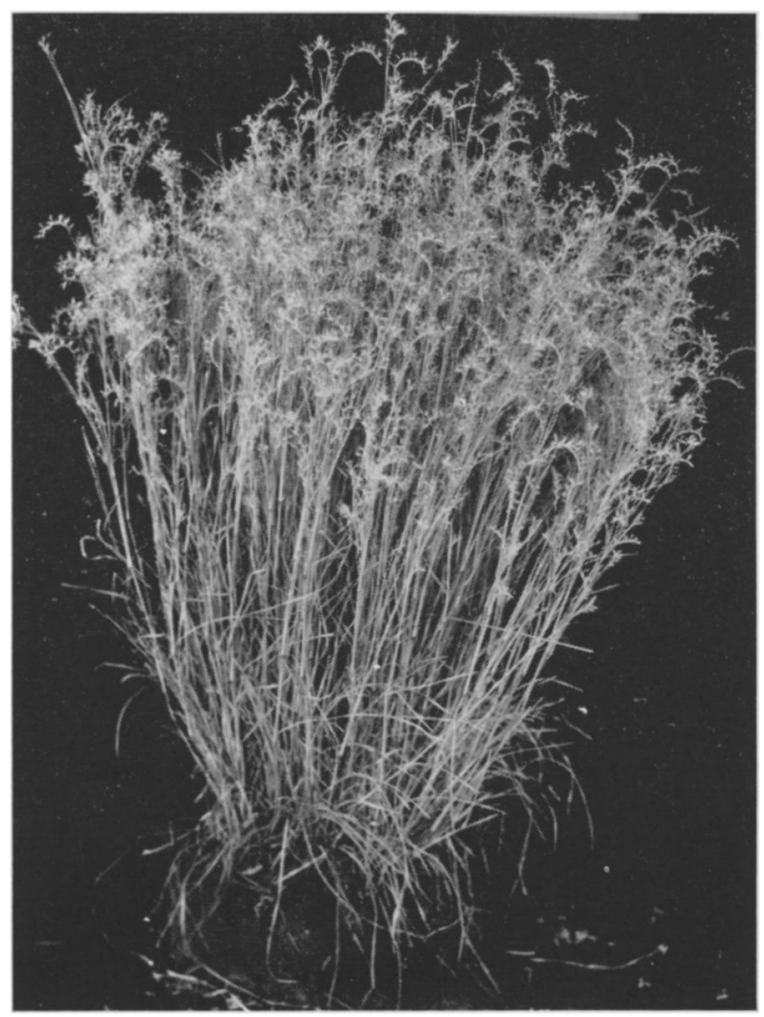

Fig. 39. Well developed relict bunch of little bluestem in seed at 30 inches height in late fall of 1938.
Psoralea argophylla, Echinacea pallida, Hieracium longipilum, Meibomia illinoensis, and Helianthus rigidus, but there were many others. But even here certain species of forbs failed to withstand the long drought. Frequently such areas were only a few square rods or a few acres in extent.

In such areas weeds were infrequent. The mesic bluegrass sometimes remained in the understory. These were the only places on upland where Indian grass could be found. Conversely, there was even some invasion of blue grama into the more open stands of the bluestems westward. But when good rains fell, crowns of little bluestem which had previously supported only a few stems became two-thirds filled with them. Flower stalks formed, seeds were ripened, and seedlings and small new tufts of little bluestem were comomn in 1943. Meantime, big bluestem had flourished, numerous long-dormant forbs appeared, and the former prairie type was almost fully restored. Even the more open stands had 80 per cent of a normal basal cover.

In a few little bluestem prairies which had not been mowed for a year or more before the inception of drought, destruction was slight and loss of species almost nil (Fig. 39). Thus, it seems certain that man by annually removing the cover aided the destructive forces of drought.

\section{Mixed Grasses}

Over considerable areas, widely scattered plants of various species recovered, reseeded, or invaded at about the same time. This gave rise to a mixed community of variable composition. It is here that the battle for dominance is being waged fiercely and may continue for a long time. Soil originally clothed with the little bluestem type is now supporting as dense a population of perennial (and mostly climax) grasses as current water content will permit. Here prairie dropseed, tall dropseed, side-oats grama, blue grama, big bluestem, and needle grass may occur in mixtures of greatly varying proportions. In later years revived little bluestem and various other grasses were also admixed. The preceding statement is typical in general for areas of varying sizes in many prairies and descriptive in particular of a large prairie near Lincoln where 25 per cent of the vegetation, exclusive of the wheat grass type, was composed of this mixture in 1943.

In certain other prairies, where an open stand of prairie dropseed had developed over a large acreage, b:g bluestem spread widely in 1942-43 and filled much of the interspace. This was accomplished by extended migration by rhizomes from relict bunches of predrought plants, and by growth from long-dormant rhizomes (Fig. 40). The vigorous culms of the invading big bluestem were 4 to 7 millimeters in diameter. Nearly all of the rhizomes and stem-bases were clearly only 2 or 3 years old and consequently of postdrought origin. Their progress from old established clumps was traced repeatedly. But the bunches of prairie dropseed were several inches in diameter; many were of predrought origin. Thus, over great 
areas a nearly equal mixture of these two dominants formed 85 per cent of the entire vegetation. Both kinds of grasses grew to unusual stature in 1943 and the crop of seed was large.

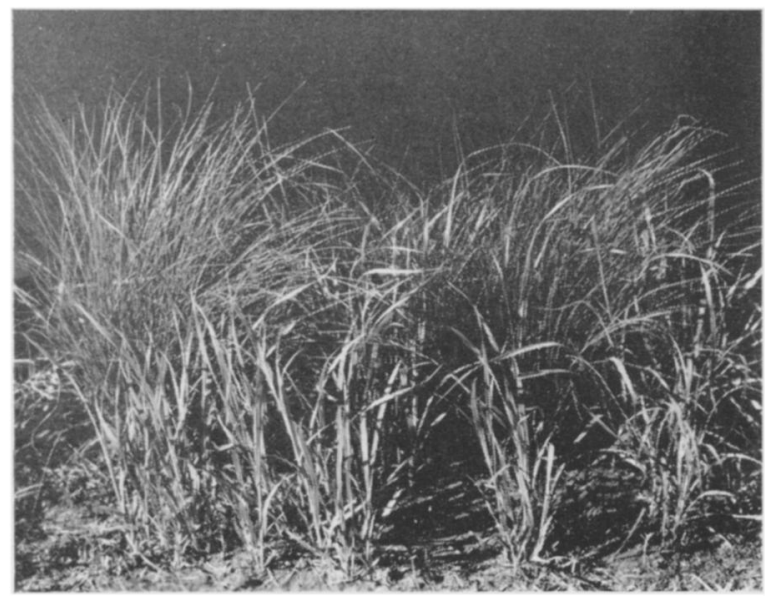

Fig. 40. Invasion of big bluestem (foreground) into an open stand of prairie dropseed (background) about 16 inches tall. Prairie dropseed in immediate foreground has been removed. Photo near Woodlawn, Neb. June 18, 1943.

During the drought, side-oats grama was sometimes dominant in mixtures with various other species, especially in 1938 and 1939, but since 1941 only a few small areas of this combination were found. In some prairies intermixtures of big bluestem and blue grama prevailed. At Hebron, Nebraska, for example, this occurred as a result of blue grama becoming widely established over a north slope where little bluestem died and (after 1939) big bluestem became dormant. It was a distinct, though open, short-grass type in 1940. But after the good rains of 1941-42 big bluestem recovered in a remarkable manner, at first in the interspaces between the mats but later by extending its new shoots directly upward through the short-grass sod.

On lowland especially, considerable mixtures of big bluestem and western wheat grass still occurred. They alternated with stands of big bluestem and side-oats grama or the three species occurred in more or less equal amounts. Even needle grass had successfully invaded drought-thinned stands of big bluestem on the lowlands (Fig. 41). Indeed, the distribution of big bluestem and needle grass occurred in a wide range of mixtures in a single prairie from scattered Stipa to relict Andropogon. Thus, in this type one found mixtures of species that were not seen in prairies before the drought.

Origin of such mixtures is still to be seen in open places where in the same square foot western wheat grass and big bluestem simultaneously extended their rhizomes to compete with recently established bunches of side-oats grama and invading Kentucky bluegrass. In fact, some local, nearly pure stands of bluegrass have also resulted from the reclothing of small por-

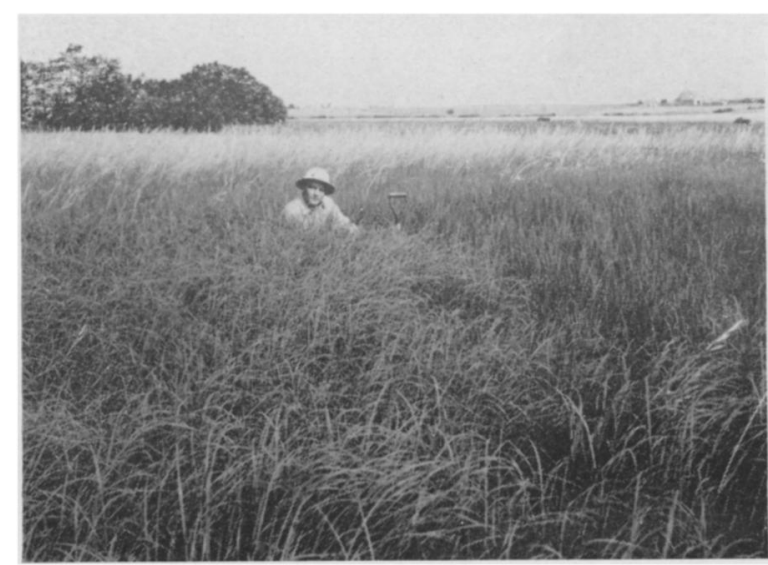

Fig. 41. Well drained level lowland near Lincoln, Neb., formerly completely covered with big bluestem. Relatively small amounts of this type remain (foreground); western wheat grass invaded the drought-bared soil and formed a distinct, pure community (right center); and the needle-grass type (light) developed in the background. Photo June, 1943.

tions of the best drought-bared region by this mesophyte.

Such mixed communities of grasses have no place in stabilized true prairie. These species have merely completed the occupation of bared soil where none of the other types have gained control. They are not climax. Nor should the student of grassland be confused by the abundance of types of communities, since once they are recognized they stand out clearly. They were commonly clearly revealed, often at a distance, because of their different colors. In early spring while most other grasses were still dormant, communities of wheat grass were so dark in color that they appeared like the shadows of clouds (Fig. 42). Later, magnificent color schemes were often seen, such as the deep green or greenish yellow of the bluestems alternating with patches and belts of the bluish green of wheat grass, and both differing markedly from the gray-green of the short grasses.

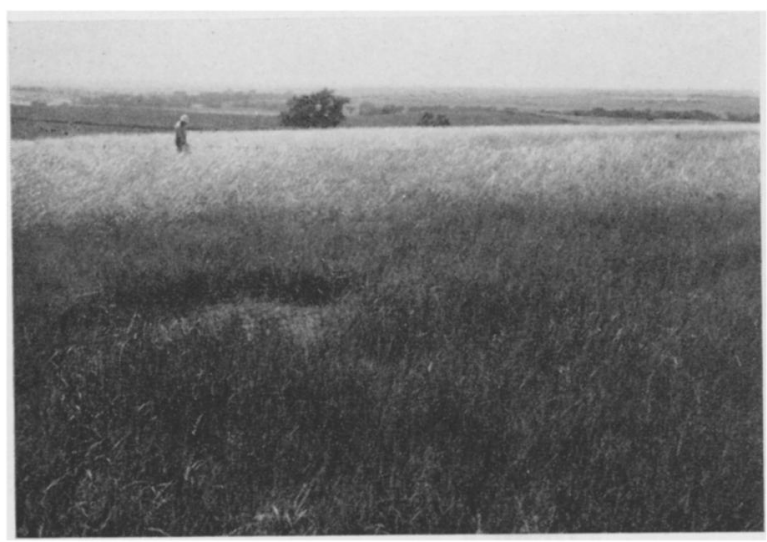

Fig. 42. Hilltop near Pleasant Dale, Neb., where the bluestem type has been replaced by a pure stand of wheat grass in foreground and needle grass beyond. Photo July 19, 1943. 
Later, during drought, the reddish cast of the bluestems, sometimes even in August a flaming reddish bronze, contrasted sharply with the wheat grass type where the foliage varied from tan to light gray. And if there had been recent showers, the short grasses regained their green color so that the boundaries of their holdings were distinct. Often differences in height were striking, as when 3 -foot wheat grass gave way abruptly to an alterne of short grass, or the foot-high short grass to a wall-like border composed of the tall foliage or even higher flower stalks of big bluestem. In drought the grasses actually shriveled in drying, and sometimes lost several inches in height. Thus, the prairie patterns changed with distance and with succeeding years. The coloration varied with the season and with the amount of precipitation. The boundaries of types were so distinet that mapping was possible along ecotones only a few feet in width (Weaver \& Darland 1944) (Fig. 43). The present
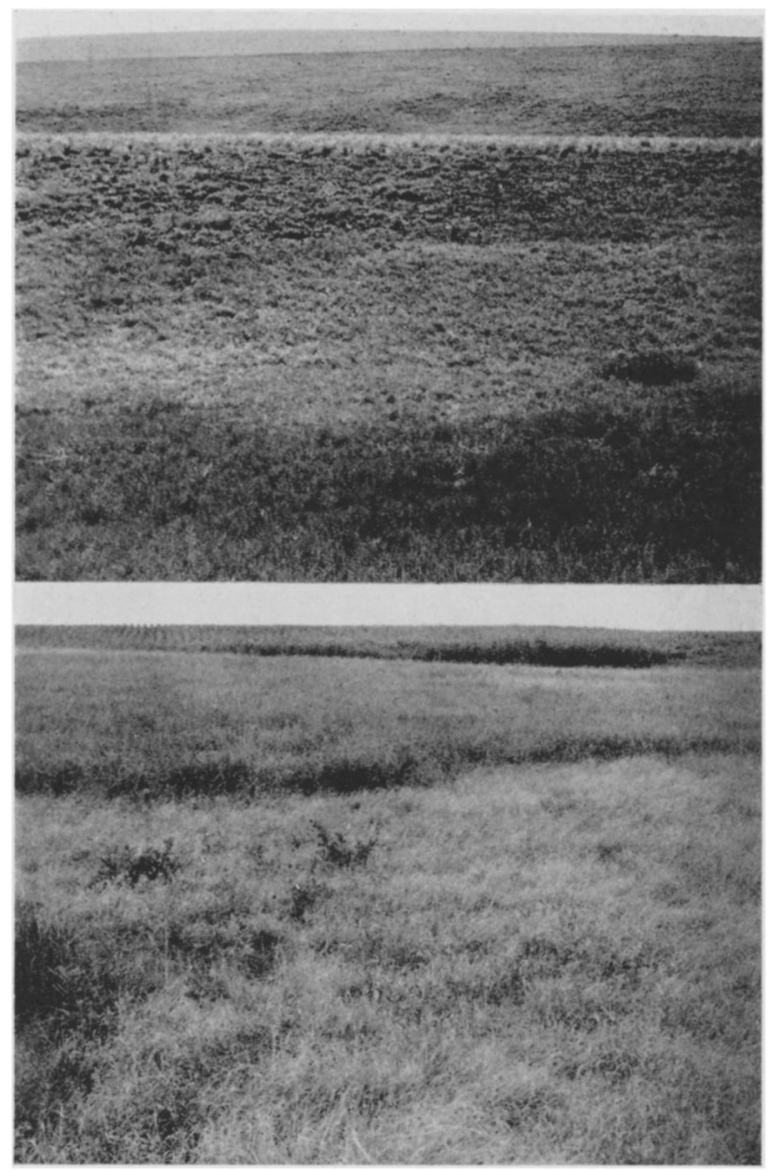

Fig. 43. (Upper) Types of grassland in close proximity at Lincoln on April 26, 1941. The zonation is a result of drought. Kentucky bluegrass occupies the ravine in foreground; relict little and big bluestems the light-colored area just beyond; the eroded bank is without cover except for dead bunches of grass on upper slope; and the white streak is the edge of an alterne of needle grass on the slope facing away from the camera. (Lower) Short grasses in foreground and big bluestem beyond. Photo Belleville, Kan., June, 1939. mosaic of grassland patterns that crystallized out of a mass of recovering vegetation in its present stage of recovery (1943) is merely one phase of a long developmental process.

The several types are listed in the order of the total area each occupied in 1943 in the 10 prairies selected a decade earlier as typically representative of drought-disturbed true prairie.
Mixed prairie type

Western wheat grass type

Big bluestem type

Needle grass type
Blue grama type

Prairie dropseed type

Relict big bluestem-

little bluestem type

Mixed grasses

\section{RECOVERY OF NATIVE GRASSES THAT DID NOT FORM TYPES}

An important part in recovery was played by various grasses which, while not retaining their dominance to such a degree as to identify a type or community, have been of enormous importance in the processes of stabilizing the habitat and promoting the development of a new cover.

\section{Bouteloua Curtipendula}

Side-oats grama has no community which it dominates, although it ranges widely from hilltop to moist ravine. In fact, in predrought true prairie it never occurred in much abundance but was only lightly intermixed with other species. But with the oncoming of drought this grass often persisted where all others succumbed. During drought it was found intermixed with ruderals of the subsere or growing in large numbers with big bluestem or western wheat grass. In fact, its history is one of repeated increase and decrease with the interchange of moist and dry years. Because of its 2.5-foot flower stalks it is considered a mid grass. Actually the foliage height, except for the two small leaves on the flower stalk, is only about 12 inches (Fig. 44). It is a bunch-

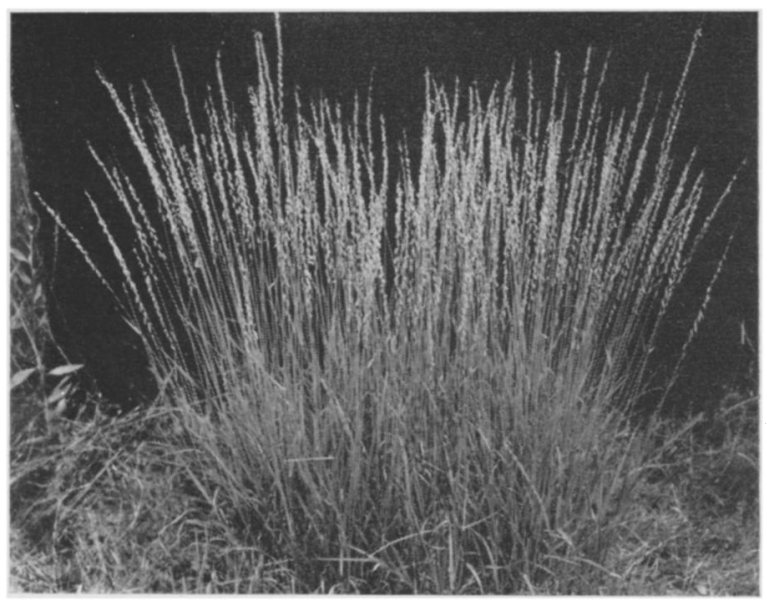

FIG. 44. Charactristic bunch of side-oats grama about 19 inches in diameter which survived the drought. The foliage is 12 inches high, the flower stalks 30 . Photo August 7, 1943. 
former, but also enlarges its bunches rapidly both by tillers and by rhizomes 2 to 4 inches long. The disadvantage in the light relation with taller grasses, due to its shorter foliage, is compensated by early and prolific seeding. It does not exhibit summer dormancy except as a response to extreme drought. This grass occurred under two rather distinct forms. During the earlier years of drought when seedlings were fewer and more distantly spaced, they developed into bunches. Many of these reached 5-7 inches in diameter and a few 10 to 14 inches. After 1940, when seed was more plentiful and seedlings more aggregated they coalesced to form a sod-mat type which densely covered the soil.

Side-oats grama is a vigorous invader, thriving in thin stands of western wheat grass as well as in open ones of blue grama or in drought-thinned big bluestem. In many prairies its great increase occurred at the same time that wheat grass spread so widely over drought-stricken prairie and often into relict stands of big bluestem. The following years usually witnessed the death of the bluestem but usually only the suppression of this grama grass, except when summer drought was extreme. Development of the earlier-growing wheat grasses surpassed side-oats grama when early spring was moist. But when spring was dry and late and early summer moist, side-oats grama flourished even in a thick stand of the waning wheat grass. Thus, following the good year 1938, this grama increased greatly and competed successfully with wheat grass. It was at this time that it reached its greatest abundance. But the next summer (1940) was one of drought. The grama seemed to have overdrawn on the water supply and it suffered enormous losses. A similar cycle but on a smaller scale occurred in certain other prairies, outside of the wheat grass type, that were much injured by the drought of 1939 . Side-oats grama lost heavily in 1940 only to recur in great abundance in 1941. Indeed, then the seed, which ripened in such great abundance in July at heights greater than that of the general mixed-grass level, could have been profitably harvested. Moreover, in areas of considerable size where bluestems had been buried by dust, it occurred during the most favorable drought years in nearly pure stands. But here too it decreased the following seasons.

The part played by Bouteloua curtipendula in recovery from drought, even if sporadic, was one of extreme importance. Disease was the cause for part of its diminution (Fowler \& Weaver 1940), a disease which at first was localized but finally spread to all the prairies. It was one of the few grasses that invaded widely and in great abundance. When seedlings were found in the wheat grass type, they were almost always those of side-oats grama or blue grama. Not only during the drought but with the coming of good years did this species aid greatly in recovery. Its seedlings alone have reclothed thousands of the smaller bare interspaces and in mixtures with others have repaired in the aggregate many square miles of grassland.

\section{Konleria Cristata}

June grass with its relatively shallow root system and decided predrought occurrence on uplands was greatly harmed by the drought. But seedlings appeared in such abundance in early spring of 1935 that portions of the more easterly prairies especially were repopulated by extensive stands of June grass. Such gains, however, were only temporary. This grass exhibits both great instability and a short life span. Later drought removed most of the new populations. Hence large, persistent bunches were rarely found during the first five years. In certain prairies where fire was used as a measure of weed control, notably at Hebron, this grass was temporarily widespread. It rarely if ever occurred in wheat grass. At the end of the drought, there was even less than at the beginning. Its role in recovery was important, however, although temporary even before good rains fell in 1941. After this seedlings were abundant over wide areas and so thick in local bare ones as to form a sod not unlike that of bluegrass in superficial appearance (Fig. 45). Thus, bare ridges, steep banks and indeed bare places everywhere presented a stage of distinct recovery. That such seed in 1941 or a little earlier resulted in permanent stands was shown by an intermixture of seedlings and bunches of different ages. In the newly populated areas the seedlings were thicker and better developed where there was some measure of protection. The plant tillers rapidly and in the second or third year tufts 2 to 3 inches in diameter produced flower stalks and a new crop of seed. It excelled most grasses in its ability to reclothe rapidly local bare spots when conditions of growth were favorable. It is not a good competitor and will gradually be relegated by needle grass, bluestems, and more stable grasses to its place as an interstitial.

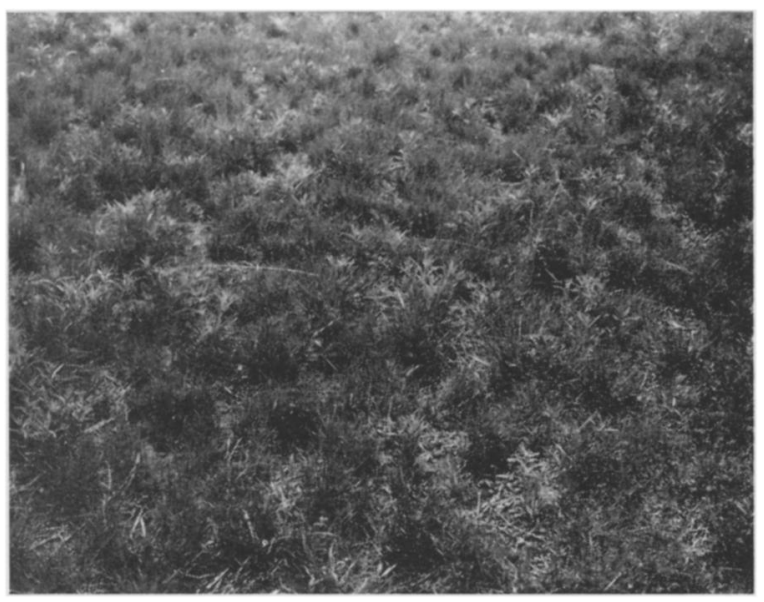

Fig. 45. Pure stand of June grass in a bared area on May 15, 1942. The plants (bunches) are mostly two years old and about 1.5 inches in diameter.

\section{Poa Pratensis}

Kentucky bluegrass was still absent at the end of the drought from all but the more easterly prairies 
and occurred in these only in ravines and other sheltered places. It did maintain its status of an adapted interstitial species in many relict areas of big bluestem. Even certain prairies near Lincoln were entirely without this species. But in 1941 it recovered in patches in ravines and spread across the upper flat portions of these on the hillsides where run-in water or melting snow furnished an additional supply of moisture. A good seed crop was produced. The following year it had revived in less mesic sites or became established there by seedlings. A thin stand developed on north-facing slopes and sometimes on portions of others as well. It spread across ravines and up adjacent slopes, sodded over all open soil, and formed an understory to the vegetation already in possession. Thus, patches of bluegrass developed, and the normal predrought understory of this mesic species became far advanced in many places. During the wet spring of 1943 this early blooming species seeded abundantly even on dry knolls and had spread outward. Over certain bared areas it had taken rather complete possession locally. It always stopped abruptly at the edges of alternes of wheat grass, nor has it invaded territory claimed by blue grama.

\section{Sporobolus Asper}

Tall dropseed usually occurred only as scattered small bunches, if at all, in predrought vegetation. During drought it increased greatly on both upland and lowland, but was never found abundantly with wheat grass. It increased its holdings after the death of the bluestems, usually big bluestem on low ground, where it now covers many square rods in pure or nearly pure stands. Young bunches with a basal diameter of about 4 inches were so numerous and the foliage cover so thick that the stand appeared very dense. A few similar patches have been found at the heads of ravines on uplands. Here it rarely dominated an area to any considerable degree but made an excellent growth in individual bunches (Fig. 46). These were usually rather widely spaced but

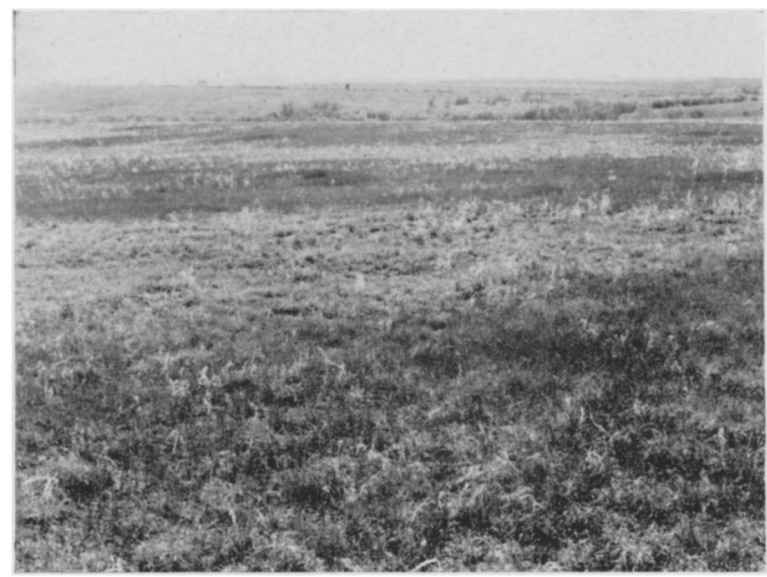

Fig. 46. Dried bunches of tall dropseed (Sporobolus asper) scattered widely over relict bluestem prairie (light) and alternes of wheat grass (dark) at Crete, Neb., on April 5, 1940. many occurred as thickly as 10 bunches of variable size per square meter. In a few instances, dense patches were found. Nearly all of these plants became established between 1935 and 1941 while the cover was still very open, since tall dropseed is not only xeric but a prolific seeder as well. Seedlings of this grass were found during dry years when most grasses had none. During the years 1939-40 only a single seedling of little bluestem was found, but many seedlings of both needle grass and tall dropseed were observed. In one circle with a diameter of 8 feet, 28 small bunches and 80 seedlings of tall dropseed were counted.

\section{Other Grasses}

Indian grass (Sorghastrum nutans), which almost disappeared from upland during drought, returned slowly from dormant rhizomes and rooterowns, but only after 1941. It survived in some prairies even on hilltops. After a year or two of good rainfall it occurred plentifully in certain places, grew to more than normal stature, and seeded abundantly.

Hairy grama (Bouteloua hirsuta) occurred rarely before the drought but increased in some prairies, as at Hebron, during the dry cycle. Purple lovegrass (Eragrostis spectabilis), always an interstitial, greatly increased its numbers during the period of good rainfall and is now of more than normal abundance in many places which were most slowly repopulated. Wiregrass (Aristida purpurea) almost disappeared during drought, but became noticeable again in 1939 .

Plains muhly (Muhlenbergia cuspidata) gradually increased throughout the drought and appeared in all of the prairies. Small pure stands of this grass became common. Its seedlings were established as early as 1938, and by 1942 bunches 5 to 8 inches in diameter were not uncommon. Its seedlings grew well under full insolation and on soil without debris. Hence, it now has a very wide distribution and has flourished during the later years.

Scribner's panic grass (Panicum scribnerianum) entirely disappeared from about two-thirds of the prairies as a result of drought. But in some it has completely revegetated bared places of a few square yards, often only to be replaced by western wheat grass. After 1940 it became common, and is rapidly taking its former place of wide distribution but moderate abundance in the understory.

Pennsylvania sedge (Carex pennsylvanica), also of grass-like form, is drought resistant and sometimes covered large patches of otherwise bare soils during the dry years. It was so widely seattered and so abundant in certain prairies as to give a light green tinge to the landscape of dried grasses in early spring. It filled many bare interspaces during drought and remains a far more abundant interstitial than formerly.

Sand dropseed (Sporobolus cryptandrus), a species of mixed prairie, invaded drought-bared pastures in true prairie in a remarkable manner in 1935-37 (Weaver \& Hansen 1941a). It also became common 
but not generally distributed in several of the prairies. It invaded only where the soil was bare. This species slowly succumbed to the shade produced by good stands of most mid grasses.

\section{FINAL RECOVERY}

Recovery of vegetation was delayed again and again throughout the seven years by losses on driest years offsetting gains made during the less dry ones. Recovery from dormancy sometimes did not oceur until one or more years after good rains came. Vegetation was usually slow and conservative in its changes. The degree of recovery varied with the amount of depletion, the type of vegetation, and the amount and seasonal distribution of soil moisture. But in 1941-43 gains were cumulative and the prairie cover again became almost complete, even though it differed greatly from the former one.

\section{Methods of Recovery}

The methods of recovery of grasses were increase in size of relicts by tillering, production of rhizomes and stolons, awakening of old rooterowns and underground parts from deep dormancy, and production of an abundance of seedlings.

\section{VEGETATIVE OFFSHOOTS}

The ability to adjust itself to the environment by various degrees of tillering accounts in a large measure for the successful occupation of more of the earth's surface by grasses than by any other lifeform. The very large size attained by relict bunches of various grasses after the early drought illustrated their adjustment to an increased water supply resulting from decreased competition. Thus, plants of side-oats grama, plains muhly, prairie dropseed, and other bunch grasses developed to great size despite the usual scarcity of soil moisture.

The extremely rapid spread of big bluestem in 1938 not only into open ground but among bunches of prairie dropseed, little bluestem, and elsewhere has been described. The great abundance of this species today, placing it second only to western wheat grass, is due first to drought survival because of its very deep root system, but thereafter to its rapid spreading everywhere by rhizomes. Wheat grass alone, among all the grasses concerned, is more efficient in this method of invasion than is bluestem. This is due in part to its resumption of growth at lower temperatures in spring and consequent evasion of drought. Occurrence of stems singly or in groups of twos or threes was common in big bluestem, frequently along a line indicating the position of the advancing rhizomes. Even side-oats grama has rhizomes 2 to 5 inches in length and these accounted in part for its great increase and mass invasions in such force as temporarily to threaten the dominance of both western wheat grass and big bluestem. The great increase and wide spreading of Pennsylvania sedge may be partly attributed to its rhizomes. Although rootstocks are absent or poorly developed in blue grama, its codominant, buffalo grass, which in- termingles with it freely and forms a denser cover than blue grama alone, is equipped with the very excellent organ of propagation, the stolon.

\section{BREAKING OF DORMANCY}

The breaking of a long period of dormancy in crowns and rhizomes of grasses was observed in some prairies after a single year of good rainfall and in nearly all, including areas of western wheat grass, in $1942-43$.

Little bluestem made some recovery, notably at Belleville and Hebron, in the spring of 1939. In general it began to break its long dormancy and rejuvenate from old crowns in 1942, only after a year of good rainfall. In some prairies as at Lincoln, such rejuvenation was not pronounced until a year later. Survival of little bluestem in a dormant state was usually only in restricted places-on rocky hillsides, steep banks, etc. But occasionally, dormant bunches were scattered thinly over an entire slope. In 1943 it revived in certain places on dry south slopes where it had not been seen since 1934 . At first only a few stems appeared even where large bunches had grown before. Often the remainder of the crown was dead. Such tufts easily could have been mistaken for new bunches developed from 1941 seedlings; actually there were but few of these. In 1943 some revived plants had only 4 to 10 stems and 1 or 2 flower stalks (Fig. 47). On the margins of the relict bluestem type, revived bunches were common. These drought relicts had produced some foliage each year but no seed. But in 1942-43 they had such an abundance of inflorescences that they formed a whitish layer at 30 inches height and well above the 18-inch foliage. A few seedlings were found in 1942 and more in 1943. Flower stalks were common to abundant in 1943 and in some places the plants were numerous.

Big bluestem likewise survived long periods of dormancy. On a north-facing slope at Hebron blue

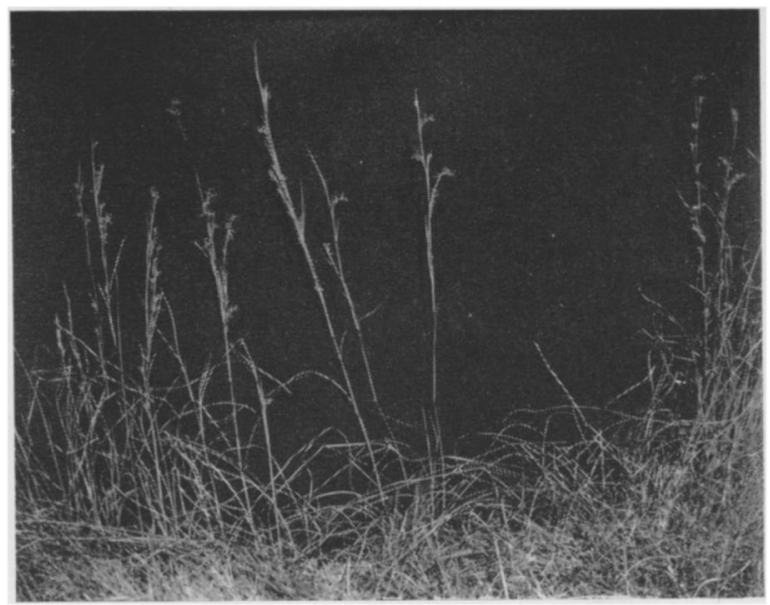

FIg. 47. Revival of relict tufts of little bluestem with 1 to 3 stems each from oll, decayed rooterowns. Other species were removed before taking the picture on September 24, 1943. 
grama formed an open stand over an area 100 yards long and about 50 yards in greatest width. In most places it was composed of much enlarged, predrought bunches spaced 5 to 10 inches apart. Since weeds were few this left irregular patches of the black soil 5 to 12 square feet in extent almost unoccupied, although bluestem prairie occurred here formerly. Little bluestem had died in 1934 and big bluestem had disappeared by 1936-37. Usually abundant, smaller and younger bunches of blue grama filled much of the interspace and portended a dense cover. But in 1942, a fine open stand of big bluestem appeared from old rootcrowns and rhizomes which had been dormant for several years. It occurred mostly in the interspaces between the bunches and sods of blue grama but its vertical stems sometimes penetrated through them as well.

At Montrose where big bluestem sod had been covered with a 2-inch layer of soil and then clothed with a practically pure stand of wheat grass, similar recovery occurred in 1942 . It was much more pronounced and widespread the next year. Similar recovery after long dormancy of rhizomes and rootcrowns was noted in various other prairies where the plants had been covered with dust or where wheat grass had absorbed the available water rather regularly in early spring (Fig. 48).

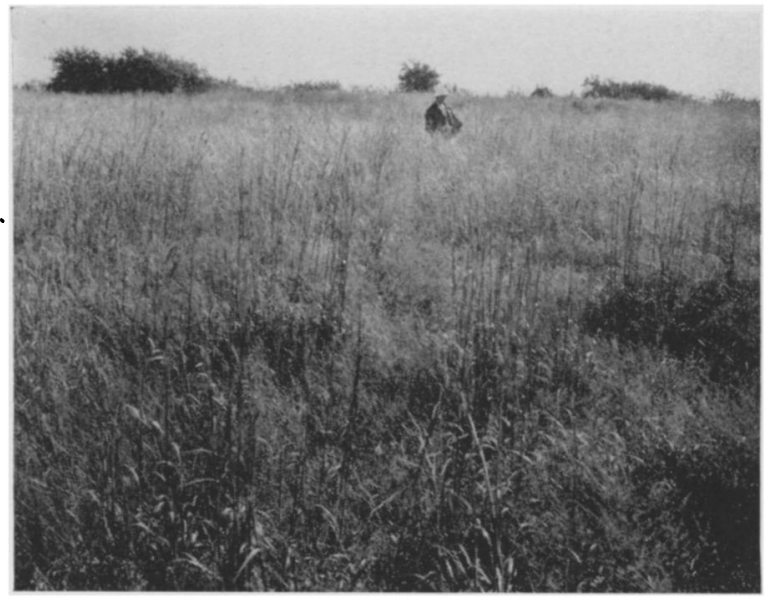

Fig. 48. Revival of reliet bluestem on an upland prairie near Lincoln after 6 or 7 years of burial under dust. There are many isolated flower stalks. Little bluestem perished; other vegetation is mostly ruderal.

In the Pleasant Dale prairie 20 sampling plots were selected in the wheat grass community, which had been well established since 1935. Care was taken to select them where the wheat grass was pure, since they were to be used to determine production of this grass compared with that of big bluestem. No big bluestem was found in any of them at this time or when the grass was clipped on May 19 and again on June 28. Neither was it observed in closely adjacent prairie where other plots were selected for later clipping when the grasses had matured. But on August 16 to 20 when a third cutting was made, considerable big bluestem had appeared in several of these plots. It was 5 to 15 inches tall, and was also scattered lightly to rather thickly and occurred widely in places where in May and June no bluestem grew (Fig. 49).

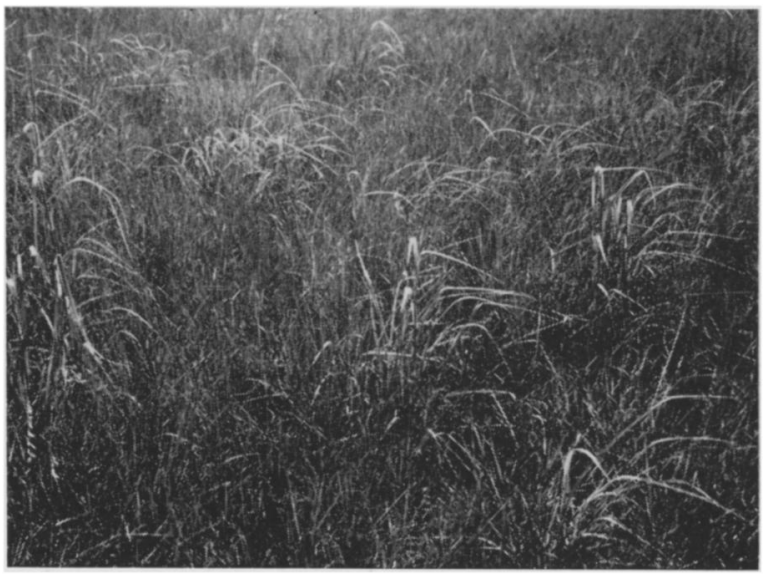

Fig. 49. Relict Andropogon furcatus that recovered after several years of dormancy in prairie near Pleasant Dale, Neb., which had been invaded by Agropyron smithii soon after 1934. Big bluestem appeared after June 28, 1943.

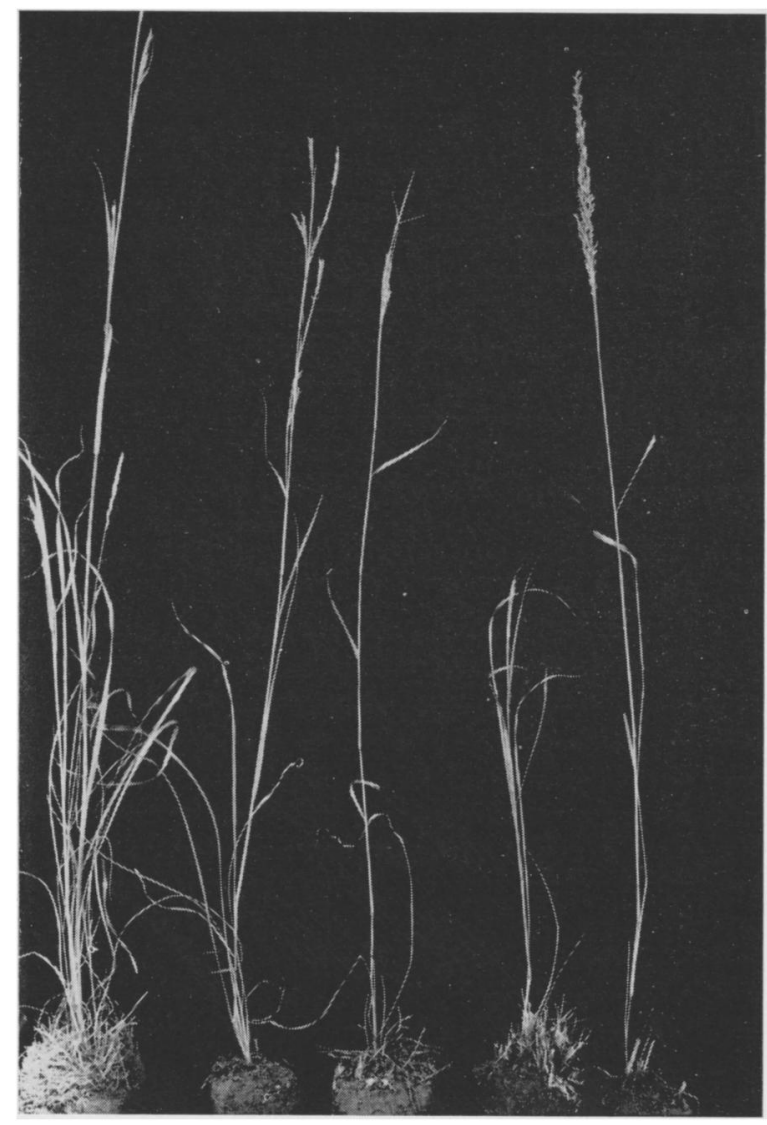

Fig. 50. Single- or few-stemmed revivals from relict upland sod at Lincoln in 1943. (Right) Indian grass, and remainder big bluestem. Height is about 30 inches. Photo September 10. 
This is excict evidence of the reappearance of a grass which had lain dormant either since 1934 (9 years) or certainly since 1938 (5 years) without appearing above ground. In most plots only a single stem or a few stems were found in a place, but in some it appeared as if the remnants of widely spread sod were growing. Consequently, several large blocks of sod were removed to a depth of 4 inches and brought to the greenhouse for study. When the tops were cut an inch above the soil and the soaked soil was slowly and carefully washed away, the skeleton of extensive rooterowns and rhizomes was found. The roots had practically all decayed, but the rhizomes were distinct, not as continuous stems but as dead, cork-like pieces .25 to 1 inch long but still in place throughout the 4 to 12 -inch interspaces between living stems. The new shoots were not from seeds but from the largest and best preserved rhizomes. The roots and tops were new but the basal portions were distinctly old rhizomes decayed away from the growing point. $\mathrm{Nu}$ merous rhizomes were found which were undecayed but apparently had no vitality; a few were seen which had a single viable bud just swelling to begin growth. Many of the survivors were clearly from previous bunches, only a few inches in diameter (Fig. $50)$. It was also found that Sorghastrum nutans, Sporobolus heterolepis, and certain other species remained dormant for a period of years.

\section{SEEDLINGS}

Although repeated reference has been made to seedlings during the drought, the bountiful crops produced following the years of desiccation warrant special consideration. They are in striking contrast with predrought conditions where relatively few of the viable seeds which fell on the prairie soil germinated under natural conditions (Blake 1935). The experience of the senior author and his students, who have yearly made minute and extended observations in listing and charting quadrats in prairie, is that seed germination under a climax cover resulted in very small numbers of seedlings and that most of these failed to survive.

During drought occasional showers moistened the soil sufficiently at irregular intervals to promote germination of seeds, including any that may have lain dormant for a long time, but establishment and continued growth of seedlings were rare. Production of viable seed by the native grasses had usually been prevented by dry weather following too rapidly a period of flowering. Exceptions occurred, as in 1935 and 1938.

Species whose seeds germinated and produced seedlings that became established during the years of less severe drought are listed in the first column below.

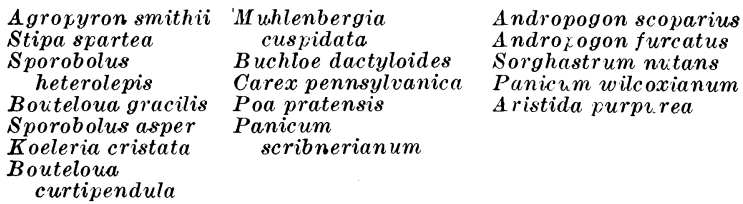

Andropogon scoparius Androxogon furcatus Sorghastrum nutans Panicum wilcoxianum A ristida purpırea

The first four of these formed prairie communities. Sporobolus asper never aggregated densely except very locally, Koeleria cristata depended upon good seeding qualities rather than stability, and Bouteloua curtipendula was quite erratic in its behavior. The second column lists less important species belonging to this group. In the last column are species which either produced no seed or seedlings or seeded only rarely before 1941 .

During the winter of 1940-41 there was considerable wind erosion and a great amount of soil heaving resulting from frequent freezing and thawing. Not only were seedlings thrown out of the soil but dead tufts and small bunches of grass in open places were heaved upward 1.5 to 2 inches. The roots were broken and the plants lay on the soil surface. Sometimes they were still attached to the soil. This phenomenon was of widespread occurrence and was most severe in places not protected by a cover of plants or a soil mulch. Even large dead bunches of sideoats grama, needle grass, and prairie dropseed 2 to 5 inches in diameter and numerous others of little bluestem had been heaved sufficiently to loosen the crowns. There was also much loosening, checking, and cracking of the soil. These cracks were 1 to 2 inches deep and .25 to .75 inch wide. The general effect was to destroy young vegetation and to mellow the soil surface. Where there was debris of any kind or a cover of vegetation the cracking did not occur. Some checking also took place in wheat grass sod but no soil heaving was observed.

Conditions for growth of seedlings in both 1942 and 1943 were excellent. In 1942, for example, the surface soil under the rapidly developing grasses was damp practically all spring and mostly throughout June, not only because of rain and heavy dew but also because of much cloudy weather. Moreover, after 1941 vegetation had thickened and furnished considerable protection to the seedlings from direct insolation, a condition which is favorable to their early development.

In the spring and early summer of 1941 there was an almost continuous supply of moisture available to promote germination and establishment of seedlings. The number and kind of seedlings in each of 25 square-foot sampling areas was ascertained in June in each of 8 prairies. A total of 24 species of grass seedlings was found (Weaver \& Mueller 1942). Of the 200 square feet minutely examined, 29 had no seedlings. Average distribution of perennial grass seedlings was less than 10 per square foot. Even if all of these had survived and made a maximum growth, they would have increased the cover in 1941 only about 2 per cent. Many of these seedlings did survive, and a new crop of seed was also produced that year. Thereafter seedlings were very abundant.

Although all of the 1941 seedlings died in the more open prairies, in others where they were better protected by a thicker foliage cover and where frostheaving was at a minimum, they tillered rapidly and established new bunches. Seedlings of the current 
year appeared in the bare spaces which in the main were well shaded by bordering vegetation, a common phenomenon over some entire prairies. Even where bare areas of a square yard or more still remained, they too usually had good stands of seedlings, especially of June grass, scattered throughout (Fig. 51).

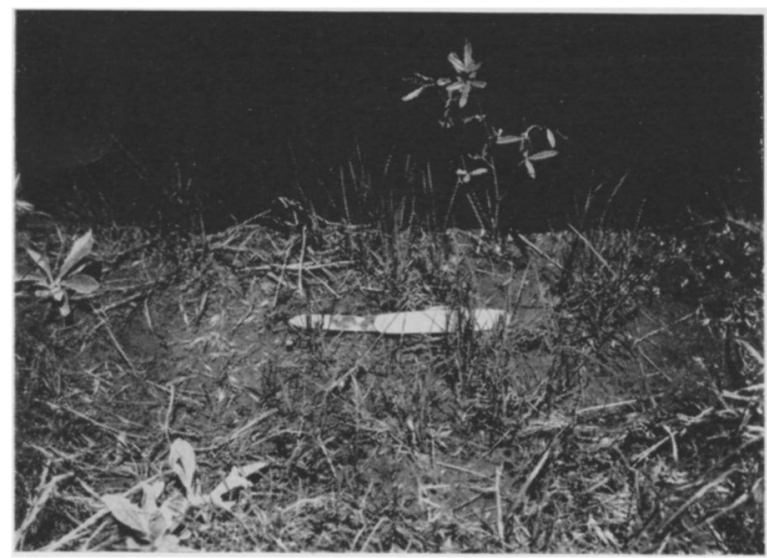

Fig. 51. Seedlings of June grass, side-oats grama, prairie cat's-foot (left), and many-flowered psoralea (Psoralea floribunda) near backdrop. Photo June 20, 1942, near Lincoln.

Heretofore, the soil in such places dried too quickly under direct insolation for seedlings to become estab. lished. All of the dominant species within the area were usually represented among the millions present, except those of the bluestems, especially little bluestem, seed of which was still rare. Blue grama, sideoats grama, and June grass were nearly always best represented where there was an intermixture of these with other species (Fig. 52). But in stands of needle grass, the tall, erect seedlings of this species alone were often found in great abundance.

By midsummer the young plants of blue grama and hairy grama were 4 to 5 inches tall and those of side-oats grama and June grass 7 to 9 inches. They were producing new tillers and new roots in great numbers. Often no bare soil was seen but a sod so dense that it seemed that the seed had been sown by hand. Success of seedlings in most places was assured by the presence of a recently developed soil mulch, a condition usually lacking during drought but a powerful deterrent to the rapid loss of surface soil moisture.

In 1943 one was impressed by a new phenomenon, that of different stages of development of the several species from seedlings to small bunches. By midsummer, seedlings of the previous year were rooted 1.5 to over 2 feet deep, and still older bunches even more deeply. The oldest were beginning to produce flower stalks and thus indicated both successful ecesis and a permanency of the cover (Fig. 53). Soon the interspaces thus sodded would lose their identity as

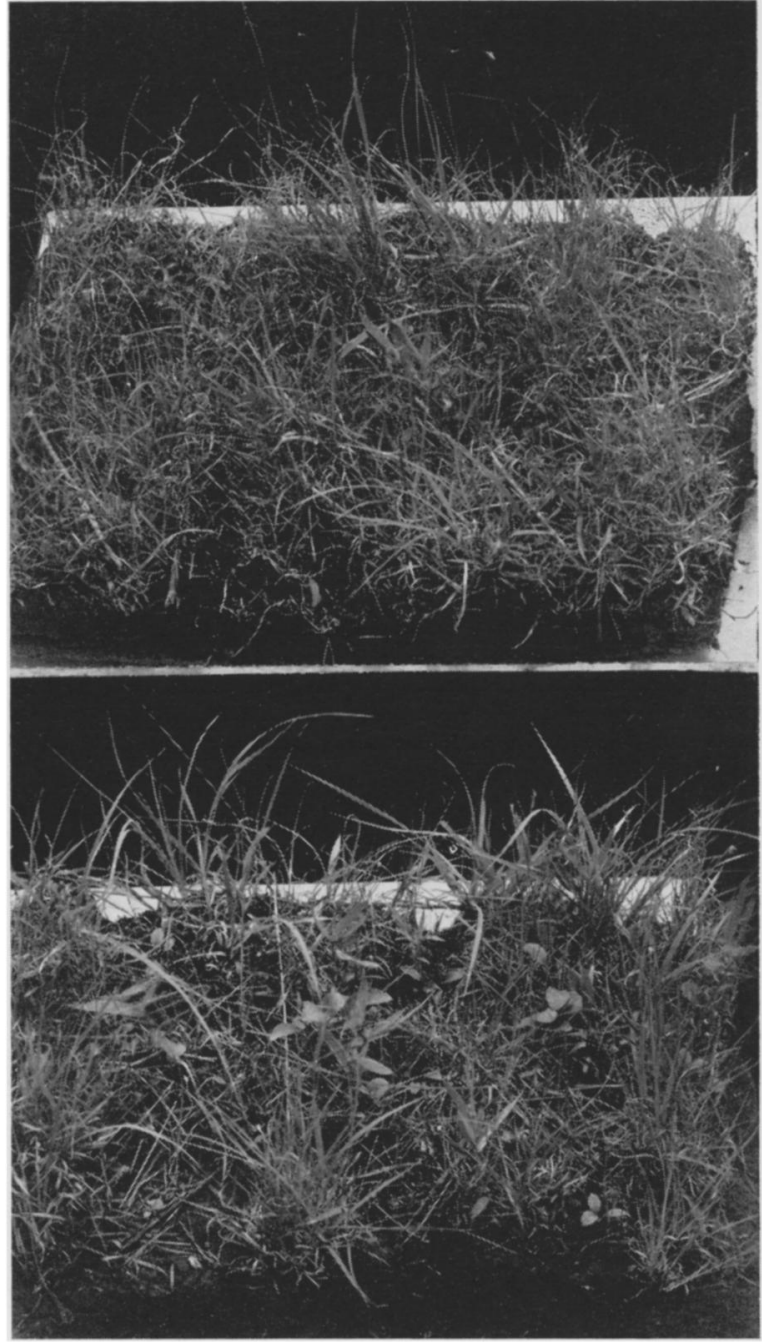

Fig. 52. (Upper) Seedlings of blue grama one and two years old, with a few of Scribner's panic grass, forming a dense sod. (Lower) Mixed year-old seedlings of side-oats grama, June grass, blue grama, and daisy fleabane. Height varies from 3 to 10 inches. Sods selected as typical of prairie at Hebron, Neb., on June 26, 1942.

the new growth merged into the general prairie cover (Fig. 54). But where some grass as bluegrass or June grass had covered a bared area in an almost pure stand, the striking difference in color demarked the spot even after the grass had been mowed. The green or bluish green of the younger plants contrasted with the gray stubble of more mature surrounding grasses. In wheat grass alone recovery by seedlings had been almost entirely replaced by a dense sod formation from rhizomes. Here, seedlings of blue grama and side-oats grama only were sometimes plentiful. Thus, except in wheat grass, reseeding had been a foremost method in recovery and in most prairies nearly all bared spaces had been repopulated. 


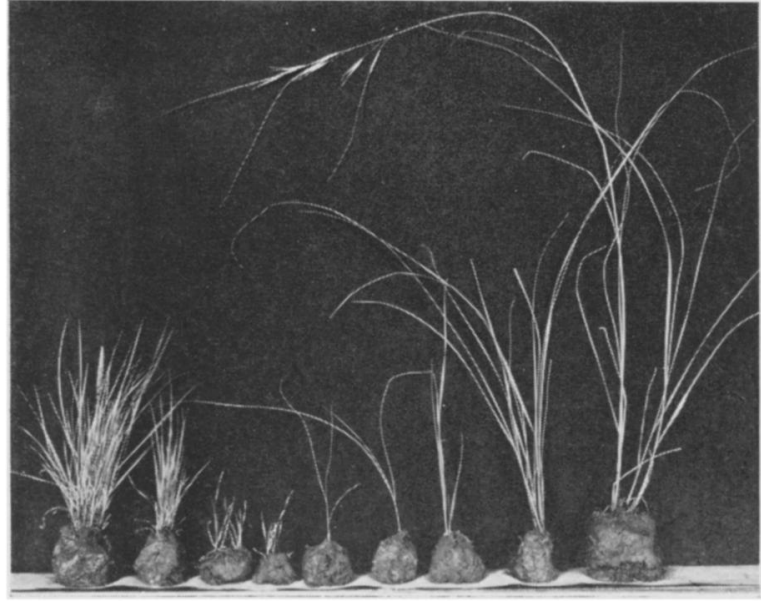

Fig. 53. Various stages in growth of needle grass (right) and June grass (left). The smallest plants are of the current year's growth (samples were taken from a prairie in June, 1943); the largest with flower stalks were completing their third summer of development.

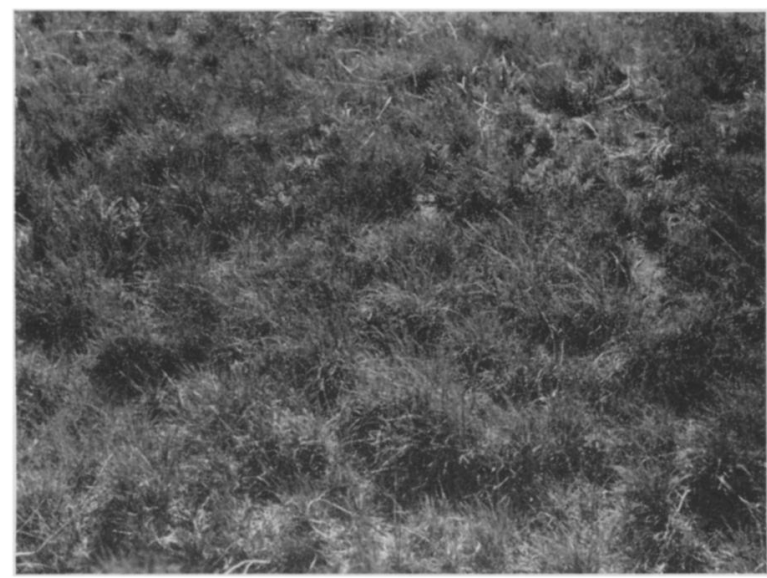

Fig. 54. Three-year-old stand of June grass in formerly bare soil in prairie near Crete, Neb., May 8, 1943.

\section{EXPRESSIONS OF RECOVERY}

Expressions of recovery were increase in numbers of plants, increase in vigor and stature, the resultant thickening of the stand and the exclusion of ruderals. Recovery was also expressed by accumulation of debris, reappearance of societies of forbs, reconstruction of a layered vegetation, and finally by an increased yield.

\section{INCREASE IN NUMBERS AND STATURE}

The number of plants increased very rapidly once adequate soil moisture was continuously available. This occurred not only as a result of the germination of seed but by vegetative means as well. Amorpha canescens, for example, put forth two to four times as many stems from its widely spreading underground parts as it did during years of water deficiency. Nearly all species with rhizomes increased the number of plants far beyond that of drought.
The breaking of dormancy added new individuals from rooterowns, rhizomes, and roots, where few or none had appeared in previous years.

Increase in vigor of growth and stature was first apparent in 1938, and was repeated regularly after a period of inactivity was followed by especially good conditions for development. But favorable conditions were long maintained only after 1941. The plants responded accordingly. The large stature and thick stand of a short grass is shown in Figure 55.

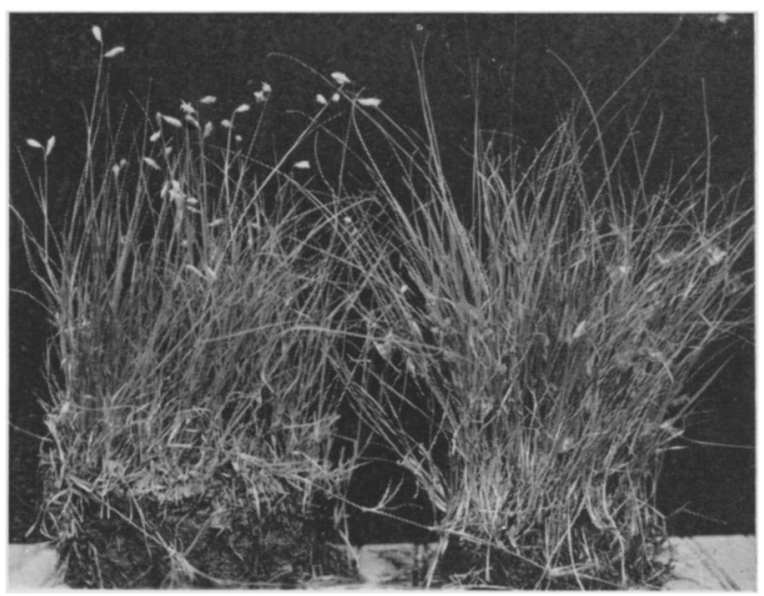

Fig. 55. Excellent growth of buffalo grass on June 10 under good rainfall in 1942. The staminate culms on the left are about 15 inches tall. Note stolons at left, and pistillate flowers in the foliage of bunch on the right.

Helianthus rigidus, normally about 2.5 feet tall and with only one or two flower heads, attained a height on the hilltop of 42 inches and the plants produced an average of 5 heads. Foliage of prairie dropseed was much taller, the leaves longer, and flower stalks higher than was ever observed in any prairie before the drought. Height growth of needle grass, Indian grass, and indeed most prairie species was unusually great. Big bluestem reached a height on upland previously found only in ravines. The increased vigor was clearly due in part to an excellent water content of soil and aerial conditions favorable to growth, and probably to the release of unusual amounts of nitrates (always low in prairie) and other nutrients from the rapid decomposition of dead underground parts long stored in a dry soil. Possibly the rest period itself may have had a stimulating effect on some plants.

The greater vigor and increased stature of plants in drought-disturbed places were very evident when the plants were compared with those in adjacent undisturbed prairie. This was done on a 400 -acre tract near Lincoln on August 7, 1943. In the disturbed portion the general foliage level of a mixture of big and little bluestem and side-oats grama was 24 inches, and the abundant flower stalks were 3 to 5.5 feet tall. The foliage cover was 95 to 100 per eent. In adjacent relict prairie, also on level low ground, the height of foliage was 14 inches, there were no flower stalks, but the foliage cover was equally dense. It consisted in part of Kentucky bluegrass with abun- 
dant flower stalks, in this old sod-bound portion. In the disturbed prairie, the foliage was very irregular in height, the basal cover was below normal, and there was a much larger percentage of side-oats grama. Forbs were few, and the understory was poorly developed. Indian grass was found in the relict prairie only, as also were Baptisia leucophaea, Hieracium longipilum, Echinacea pallida, Salvia pitcheri, and numerous other forbs.

Thickening of the stand was pronounced everywhere. Bunches that before were only sparsely filled with stems now produced them in great abundance. One of the most impressive features of prairie in 1943 was the density of the foliage. Where much bare ground was formerly exposed there was now sufficient cover to conceal the soil, unless one looked almost vertically downward. In relict stands of bluestems, foliage cover was sometimes 100 per cent. There was a scarcity of most forbs, and an unusual prevalence of grasses. The increased cover had a very marked effect upon reducing the light and excluding weeds. This change added greatly to returning the prairie to a more normal appearance.

With increase in plant population and amount of foliage, there was also an increase of debris. In most places enough plant parts had accumulated to cover the soil with a thin mulch, which was quite in contrast to the bare, black soil even in 1940-41.

\section{REAPPEARANCE OF FORBS}

Little replacement of the native forb population occurred over a period of 6 or 7 years, since failure to complete vegetative growth or to blossom or ripen seed was usual. Seasonal aspects, if any, were poorly marked. There was both a dearth of seed and an unfavorable environment for germination and establishment. Seedlings of forbs were rare until 1941-42. Many forbs which had vanished from all but relict patches of little and big bluestem prairie returned

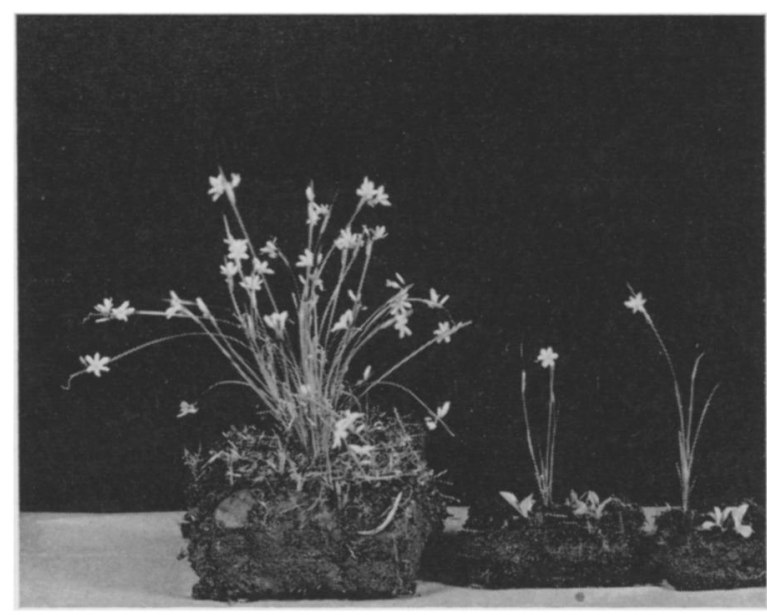

FIG. 56. Single relict plant of blue-eyed grass (Sisyrinchium campestre) with 36 scapes and over 200 flowers and flower buds. Year-old plants (right) with one or two flower stalks about 6 inches tall. Note also seedling plants of prairie eat's-foot. Grasses have been removed. Photo May 19, 1943. after a year or two of good precipitation. Sisyrinchium campestre which had not been seen anywhere after 1934 occurred in great numbers in 1943. This vernal species must have sprung from seed widely scattered, even in the driest places, since practically all plants had only one or two stems. After long search a predrought specimen of large stature was found in an old trail where it had endured the drought (Fig. 56). Of course, the seedlings might have started growth a year before they blossomed and their grass-like leaves had escaped observation. But in 1943, plants were comomn to extremely abundant over all the prairies including the wheat grass type. At Valparaiso, for example, they grew more thickly than if the stands of 7 normal years had been combined. Thus, they more than compensated in seed production the loss in the long years of drought (Fig. 57). Quadrats placed at random revealed an average of 224 plants and 368 flower stalks per square meter. There were no big bunches. The plants appeared to be only 1 to 3 years old. Such dense and continuous stands as these had never before been seen.

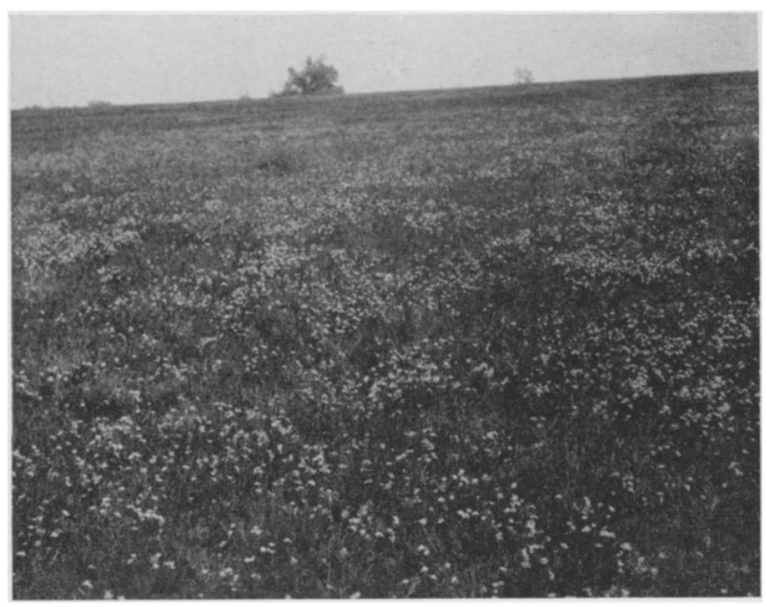

Fig. 57. Vernal society of blue-eyed grass on hillside in prairie at Valparaiso, Neb., May 19, 1943. All are young plants.

Viola pedatifida, another species of the understory, was found only rarely and always as single individuals on low, relict prairie during drought. It now became common, and occurred on uplands in several prairies, but not abundantly.

Antennaria campestris, formerly occurring widely and in great patches in the understory, became rare in the prairies after 1936 . It had returned mostly as individual plants, although a few small patches survived. At first the plants had only one or two stems and no flower stalks. Where a few mats of this stoloniferous composite were found, the largest seldom exceeded 1 to 1.5 square feet in extent and it could easily be seen that all but the central part was relatively new growth (Fig. 58).

Nothocalais cuspidata, formerly widely but lightly scattered among the grasses, like Hieracium lona:- 
pilum, disappeared for a period of years but reappeared slowly in 1943, undoubtedly from seed. Quite in contrast to these was downy gentian (Gentiana puberula), formerly found but rarely. It had increased with the cessation of drought and now occurred in such abundance that 15 or more plants were counted in a space of a few square rods.

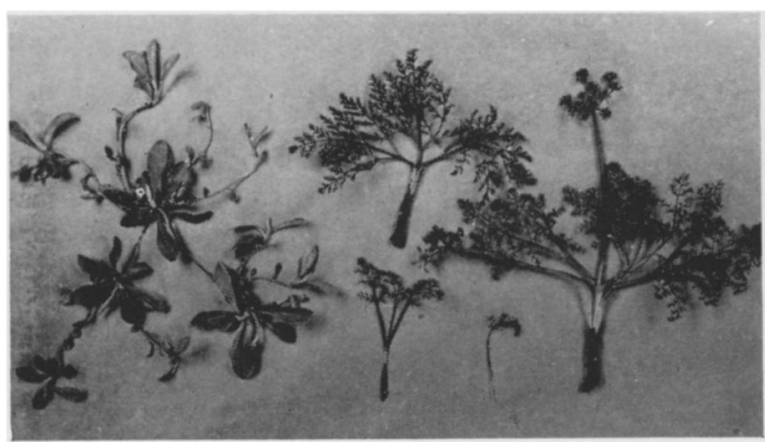

Fig. 58. Mat of Antennaria campestris about 8 inches in diameter on left. The central stem is two years old. The two lower, large tufts are a year old, and the new growth is of the current year. Photo May 19, 1943. On the right is a seedling Cogswellia daucifolium and plants 1,2 , and 3 years old respectively.

Species of Cogswellia had again become very abundant in patches in thin soil on slopes and hilltops. This increase was by seedlings; not all but most of the old plants had died from desiccation (Fig. 58). Seedlings and young plants of Kuhnia glutinosa have been found in considerable numbers since 1942 about the relatively few old plants that survived the drought, probably because of their extremely long taproots.

Vicia americana which decreased almost to the point of vanishing appeared again in considerable abundance. Salvia pitcheri, a tall and conspicuous blue sage, was represented widely by seedlings and young plants over many lower slopes. Only rarely did a mature plant survive the drought. Silene antirrhina, very abundant in early drought, appeared again in considerable abundance in 1942, after a period of 6 years. This was true also of the annual yellow flax (Linum sulcatum) and milkwort (Polygala verticillata). In the few prairies where it occurred in 1933, Morongia uncinata, which had become rare, greatly increased. Quite to the contrary, plants of Opuntia humifusa nearly all died.

Certain species with strong taproots and well developed rootcrowns became dormant and stems did not appear above ground during a period of 5 to 7 years. Astragalus crassicarpus was rarely seen during the drought and then always in places of unusual moisture supply. Many young plants were observed and excavated in 1943, but they were only 1 to 2 years old and did not blossom (Fig. 59). Not infrequently a group of 3 to 5 growing together from seed of the same fruit appeared as one large plant. Conversely, the single small shoot, or sometimes two or three from an old crown, could be mistaken easily for a two-year-old seedling. Many large rootcrowns (probably 10 to 15 years old) which formerly sup- ported numerous widely spreading shoots were so weakened that they gave rise to only one or two shoots. During the years 1942-43 only a single old plant was observed that flowered and produced fruits in normal abundance.

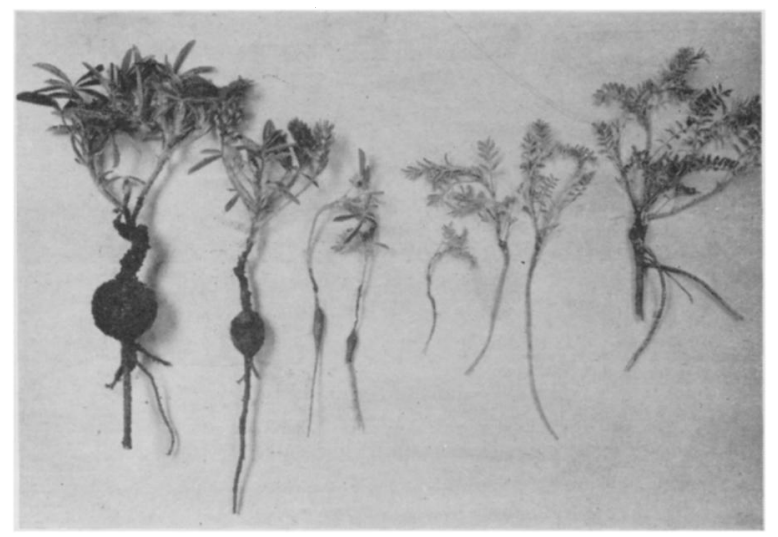

Fig. 59. Astragalus crassicarpus 1,2 , and 3 years old (right). Psoralea esculenta with the enlarged tap root, 2.25 inches in diameter, is a survivor of drought. The two younger plants on the right were in their second year of growth. Photo May 19, 1943.

Psoralea floribunda was represented by many seedlings during the 3 years of recovery. The new singlestemmed plants ranged from 5 to 10 inches in height. But exactly similar plants were found arising from large roots or rootcrowns, often much decayed, which had been dormant during the long drought. The silvery psoralea ( $P$. argophylla) recovered from drought in a very similar manner; seedlings frequently occurred in great abundance. Some seedlings of $P$. esculenta, 1 to 3 years old, among the many observed, were excavated. The excellent storage organ, a much swollen root, enabled some plants to endure the drought; the buds on the rootcrowns survived long periods of dormancy (Fig. 59).

Hundreds of small, single-stemmed plants of Baptisia leucophaea were observed, especially in 1943. All that were excavated had arisen from the old rooterowns. Many of these were of great size and had previously supported large many-stemmed plants. Often much of the old crown or taproot had decayed. While many new plants of Lithospermum linearifolium and fewer of L. gmelini grew from seed in 1942-43, others arose from predrought rooterowns. During the drought most of these did not produce new growth above ground. The prairie clovers, Petalostemon purpurea and P. candida, reappeared from rootcrowns as did also an occasional purple cone-flower (Echinacea pallida).

Helianthus rigidus again appeared in something of normal abundance in parts of certain prairies for the first time since 1934. All plants examined were from rhizomes or rooterowns and not from seed. Many new offshoots sometimes resulted from a single relict plant. Most plants of Liatris scariosa were killed, a few endured as corms. Erythronium mesochoreum survived the drought because of its deeply placed 
bulbs and spread widely even onto uplands when drought removed the intensive competition of a closed plant cover. Conversely, Lepachys columnifera survived the drought in the seed stage.

Throughout the drought years the seasonal aspects were almost absent, so scarce were the forbs (Weaver \& Albertson 1943). Although the flora of forbs had distinctly increased in both species and abundance in some prairies, in others scarcely more than a dozen perennial species occurred. They were always fewest in a cover of western wheat grass. For example, 20 species of perennial forbs were counted in a large upland prairie at Crete in 1943 , but only 6 in the portions covered with wheat grass. To appreciate their scarcity, compared with predrought abundance, one had only to find a broad ravine in which little bluestem still persisted. Accompanying it were many species (23 in a ravine at Crete) such as Meibomia illinoensis, Fragaria virginiana, and Artemisia gnaphalodes, which had entirely vanished elsewhere.

RESPONSE TO DROUGHT OF POSTCIIMAX PRAIRIE

Following the years of good precipitation, the lowland vegetation made a remarkable growth in 1943 . On bottomland prairie along the Weeping Water River near Union, Nebraska, tall panic grass on June 24 had attained a height of 40 inches and slough grass 64 inches (Fig. 60). Big bluestem had a foliage level of 32 inches but nodding wild rye was 4 to 6 inches taller. The stature of the forbs was likewise impressive. Leaves of Fragaria virginiana were often held a foot high in dense shade. Anemone canadensis was 17 inches high and Rudbeckia hirta reached the general level of the bluestem foliage.

In September the height of foliage and flower stalks of the grasses was again recorded in inches as follows-height of flower stalks being in parentheses: Spartina pectinata, 75 (117); Andropogon furcatus, 72 (113); Sorghastrum nutans, 82 (108); Panicum virgatum, 50 (90); and Elymus canadensis, $60(73)$. The grass was thick and formed a wall beyond the swath of the mower. The leaves of slough grass, for example, were 8 in number; only the two lowest were dead, despite the dense shade. Average length was about 48 inches and the width was three-fourths inch. Water had been plentiful at all times and the yield was more than 4 tons per acre.

Almost equally good growth, and quite beyond the normal, was observed at Lincoln, where slough grass was rather constantly supplied with an abundance of water for the first time since the drought. This grass reappeared in certain ravines where during drought a dense stand of wheat grass prevailed. Its large coarse rhizomes had remained dormant. Other species that behaved similarly in less moist portions of ravines were tall panic grass, wild rye, and big bluestem. After the mass invasion of wheat grass and its absorption of the soil moisture in early spring, they remained dormant, or grew feebly during 1938. All of these species are well provided with at least short rhizomes.

A remarkable change in the population of grasses occurred in the lower portion of a postclimax prairie near Greenwood in eastern Nebraska. This tract has been under close observation since 1936, since it has been used in experimental work (Marsh 1940, Weaver \& Hansen 1941) and also for study by classes in ecology. This tall-grass prairie was on nearly level land on the outer edge of the flood plain and onehalf mile from Salt Creek. Precipitation was supplemented by runoff water from surrounding low hills and from the upper portion of the prairie which extended half a mile along a broad depression to higher land. When fenced in 1937, big bluestem composed fully 95 per cent of the grasses, although formerly there were considerable amounts of slough grass scattered throughout. The prairie was mowed for hay late each year.

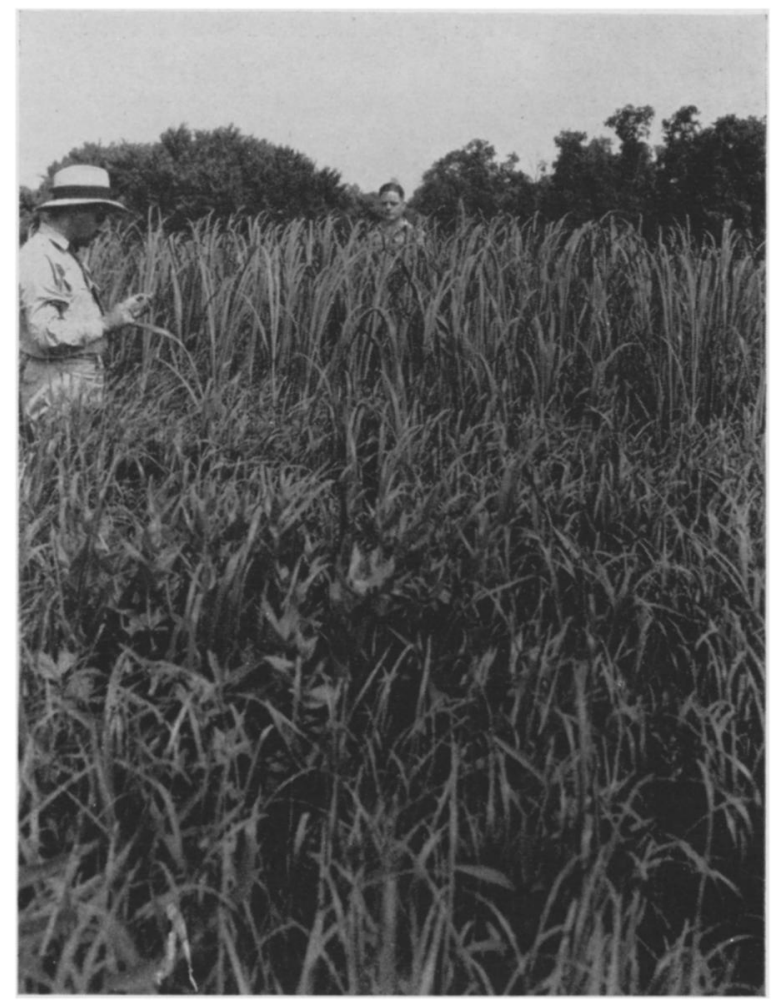

Fig. 60. Postelimax prairie near Union, Neb., on June 24,1943 . Tall panic grass in foreground is 36 inches tall, and slough grass in background is 64 inches high. The largest stems were $13 \mathrm{~mm}$. in diameter.

The soil was so wet during 1937 that even in June the surface was constantly saturated. This was by far the best year for growth until 1943, and the yield of hay was approximately 4 tons per acre. The following year was drier, since there was on'y one heavy spring rain with high runoff, but the blusstems made a good growth (F.g. 61). Severe drought occurred in both 1939 and 1940 (Fig. 62). There was an excellent growth of $b^{\prime} g$ buestem during the years of better prec pitation (1941-42) but little change in the composition of the vegetation.

The prairie was burned in winter of 1942-43 and 


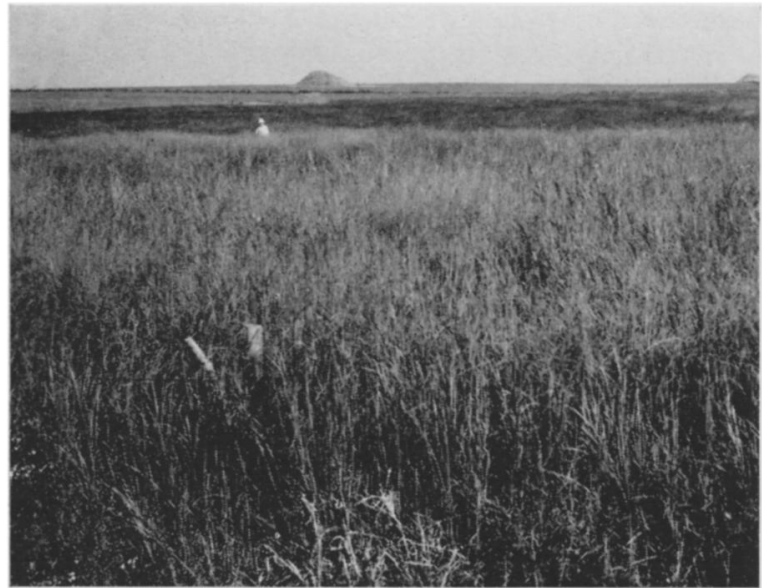

Fig. 61. Postclimax prairie at Greenwood, Neb., in September, 1938. The average height of the nearly pure growth of big bluestem is 5.5 feet. Only a small amount of slough grass, the inflorescences of which photographed dark, was present.

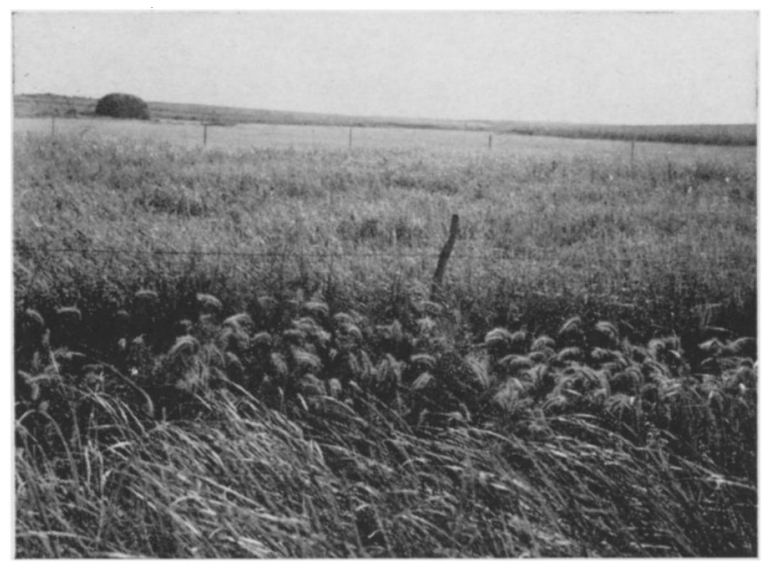

Fig. 62. View of same area as Figure 61 on September 29, 1940, after two dry years. Big bluestem is about 2.5 feet tall. Nodding wild rye and slough grass (which did not produce flower stalks) occur in the roadside diteh in the foreground.

heavy rains in the spring deposited a thin layer of silt, about .25 inch deep, over the whole area. Big bluestem did poorly during the late, wet spring, but slough grass appeared nearly everywhere and flourished. An examination on August 4 revealed that slough grass was scattered lightly to thickly all through this level land and that big bluestem formed an understory. It was 36 inches tall where slough grass composed half or more of the mixture and only 12 to 18 inches where this hydrophyte was thickest. The bluestem leaves were narrower and more attenuated than where this grass grew alone. Many leaves were dead. Rhizomes of slough grass apparently were widely distributed all through this grassland but most of them had been dormant during the years of drought. Slough grass had grown luxuriantly, reached a height of nearly 7 feet and blos- somed early in August (Fig. 63). It was estimated that the increase of slough grass over previous drought years was 10- to 12-fold. Panicum virgatum and Elymus canadensis had both increased, but to a much smaller degree. The understory of shadeenduring mesophytes remained undisturbed but an increase in stature of certain tall, late-blooming forbs was very noticeable. Thus, it seems that this postclimax prairie had high potentialities, the more hydric slough grass dominating in a series of wet years and big bluestem during the drier ones.

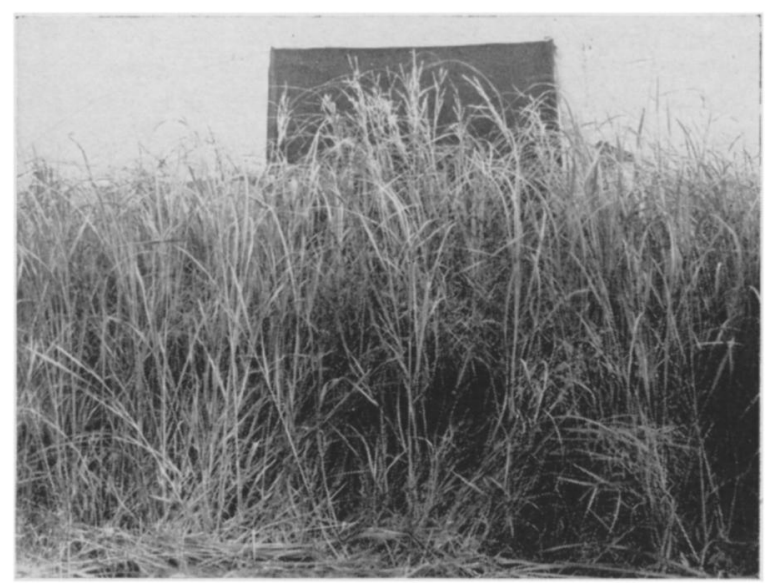

FIg. 63. Detailed view in the same prairie on August 4,1943 , when an excellent growth of slough grass 6 to 7 feet tall from formerly dormant rhizomes suppressed much of the big bluestem. The vegetation was too tall to secure a general view as in preceding years.

\section{INCREASE IN YIELD}

Dry weight has long been considered the best measure of growth. In determining plant production in relation to water content of soil, yield from five sample plots, each 4 square meters in area, had been taken at many prairies during the last dry year (1940) and the first moist one (1941). These prairies included Lincoln and Hebron, Nebraska, and Belleville, Kansas (Weaver \& Albertson 1943). Yields were not obtained in 1942 but they were ascertained again, from 10 plots of 2 square meters each, in each prairie in 1943. Each year all samples were taken in the relict bluestem type, except at Lincoln. They were from areas selected as typical of the type. During each of the three years the plots at Lincoln were on rolling topography and the vegetation varied from nearly pure prairie dropseed through mixtures of bluestem to nearly pure needle grass. At Belleville the sampling areas were on an east slope, at Hebron they were spaced over rolling terrain.

The annual precipitation was not so high in 1943 at any of these stations as it was in 1941 and 1942. Yields, however, were high, since the preceding years had built up a reserve of soil and subsoil moisture, such reserve not being present in 1941. Moreover, rainfall in spring and early summer was ample (Figs. 2 and 3). Late summer drought, however, did reduce an otherwise excellent yield (Table 7). 
Yields from the 10 plots at Lincoln were very consistent, except for a single low yield (998 grams) from needle grass. Otherwise they ranged between 1,083 and 1,301 grams per plot. This revealed a fairly uniform distribution of a good cover. At Belleville the vegetation was less uniform. About half of the samples were of big bluestem and the remainder of nearly pure little bluestem or with this species at least dominating and big bluestem ranking second. Little bluestem yielded much less and variations in the plots were from 541 to 1,055 grams. At Hebron the chief species in every sample was big bluestem. Side-oats grama and little bluestem were the other important grasses. Here the yields ranged between 643 and 1,059 grams. Flower stalks, except of blue grama, constituted no part of the yield, since the grasses were harvested in August before they had developed. There were very few forbs. Yields at the three stations for the last year of drought, 1940, and the good years, 1941 and 1943, are shown in Table 7.

Table 7. Total yield in grams per 20 square meters and in tons per acre at three prairie stations during three years.

\begin{tabular}{c|c|c|c|c|c|c}
\hline \hline \multirow{2}{*}{ Station } & \multicolumn{2}{|c|}{1940} & \multicolumn{2}{|c|}{1941} & \multicolumn{2}{|c}{1943} \\
\cline { 2 - 7 } & Grams & Tons & Grams & Tons & Grams & Tons \\
Lincoln..... & 4,587 & 1.02 & 7,341 & 1.64 & 10,596 & 2.36 \\
Hebron.... & 2,832 & 0.63 & 8,728 & 1.95 & 9,025 & 2.01 \\
Belleville... & 3,326 & 0.74 & 8,781 & 1.96 & 9,320 & 2.08 \\
Average. . & 3,582 & 0.79 & 8,283 & 1.85 & 9,647 & 2.15 \\
\hline
\end{tabular}

These yields correspond in general with the precipitation and especially the available soil moisture as has been shown for the last dry year (1940) and the first moist one (1941) by Weaver and Albertson (1943). Severe midsummer drought occurred at all the stations in 1940 (Fig. 4). The green color of the grasses practically disappeared in July when the bluestems turned reddish brown as they normally do in October. The grasses dried and yields were low. In 1941 precipitation was far above normal except at Lincoln, a condition which is reflected in the lower yield at this station. Rainfall was especially heavy during April, May, and June, but with few exceptions a good water content of soil was maintained at most soil depths throughout the season.

Although the total precipitation in 1943 was somewhat less than that of either of the two preceding years, this deficiency occurred mainly late in the year after the grasses had made a good growth. In 1942 the subsoil had received much moisture and this reserve supply was available for growth in 1943 (Fig. 5). Soil sampling at Belleville and Hebron was done only intermittently in 1943 . At both stations the soil was wet to at least 6 feet late in May. In July and August both rainfall and water content of soil were less at these stations than at Lineoln, a fact which probably accounts for the differences in yield.

Since this is a study of recovery as expressed in yield, only the average differences by years need be considered. Total plant production in 1941 was 2.3 times that in 1940. Yield in 1943 was 2.7 times as great. Moreover, yield in 1943 was 1.2 times as great as that in 1941. This last difference is not because of more precipitation in 1943, but is due to the cumulative effect of the thickening of the plant cover.

\section{DISCUSSION}

Extended studies in true prairie before, during, and following the great drought have revealed that this grassland represents a very complex and an exceedingly dynamic community. It possesses dominant species of various extraction. Little bluestem, big bluestem, Indian grass, prairie dropseed, and tall panic grass have come from a warmer, southern climate. Needle grass, June grass, nodding wild rye, and western wheat grass are northern in origin. From the high plateaus of the arid southwest have come side-oats grama and blue grama. Buffalo grass is from the semiarid west. A mixture of these species denotes great potentialities as regards adaptation to wetter and drier sites, seasons for growth, and adjustments to periods of moist years or to eycles of drought. These species also exhibit varying degrees of tolerance to shade, to annual mowing, and to grazing.

Adaptation to lowland, upland, and intermediate sites was clearly expressed in the several grassland types or communities, as was shown by extensive predrought studies (Weaver \& Fitzpatrick 1932, 1934). Cool season species make their chief growth in spring and produce seed in early or midsummer. They resume growth in fall and thus greatly extend the length of seasonal activity and the period of green forage for eattle. Warm season species begin development much later in spring but grow continuously until early fall and thus produce much foliage in midsummer.

During years of normal precipitation, the more mesic grasses, especially the bluestems and the introduced Kentucky bluegrass, with their dense stands and luxuriant foliage almost overwhelmed most other upland prairie grasses. Exceptions were needle grass and prairie dropseed, each of which dominated communities on many drier hillsides. Species of high drought resistance, as side-oats grama, blue grama, and buffalo grass, or those well adapted to evade drought, as western wheat grass and Pennsylvania sedge, occurred only in small amounts. None composed as much as one per cent of the basal cover, as was shown by very extensive quadratting and observations over a period of years (Weaver \& Fitzpatrick 1934). But these grasses were the reserves adapted to a more xeric climate where mesic competitors were fewer and less aggressive. When drought came and most vegetation was swept away, it was then that they increased rapidly and spread widely. With needle grass and prairie dropseed, which also migrated outward from their former restricted areas, they repopulated the soil and completed a new prairie cover. Thus, on upland as well 
as on lowland, in the mixture of grasses there are species adapted to different extremes of prairie climate. Nature has at hand but in reserve a group of grasses and forbs well fitted to endure great drought. Nor has drought swept away all of the grasses and forbs best adapted to furnish the prairie cover in times of good supplies of moisture in soil and air. In seeds, rootcrowns, rhizomes, roots, or other parts, undoubtedly life in some of all prairie species remains. They will probably reappear and resume their former place in grass'and.

Complete recovery, even under the most favorable weather, will require much time. Return to the predrought dynamic equilibrium of climax types will necessitate many changes. Western wheat grass is now so firmly established that its suppression as well as that of the short grasses may occur slowly. The area dominated by needle grass may also again become greatly restricted. Not only is time required for the suppression of the more xeric species but also for the more mesic ones to regain the:r former great abundance and wide distribution. Many years with good precipitation will be required to replace in grassland its various societies of composites, legumes, and other forbs. Much time will be needed to rebuild into the prairie its layered structure, and for it to regain the same high degree of dynamic stability that it possessed before the great catastrophe of drought.

\section{ENVIRONMENT IN MIXED PRAIRIE}

A marked change in the environment of mixed prairie followed the extremely dry winter of 1939-40.

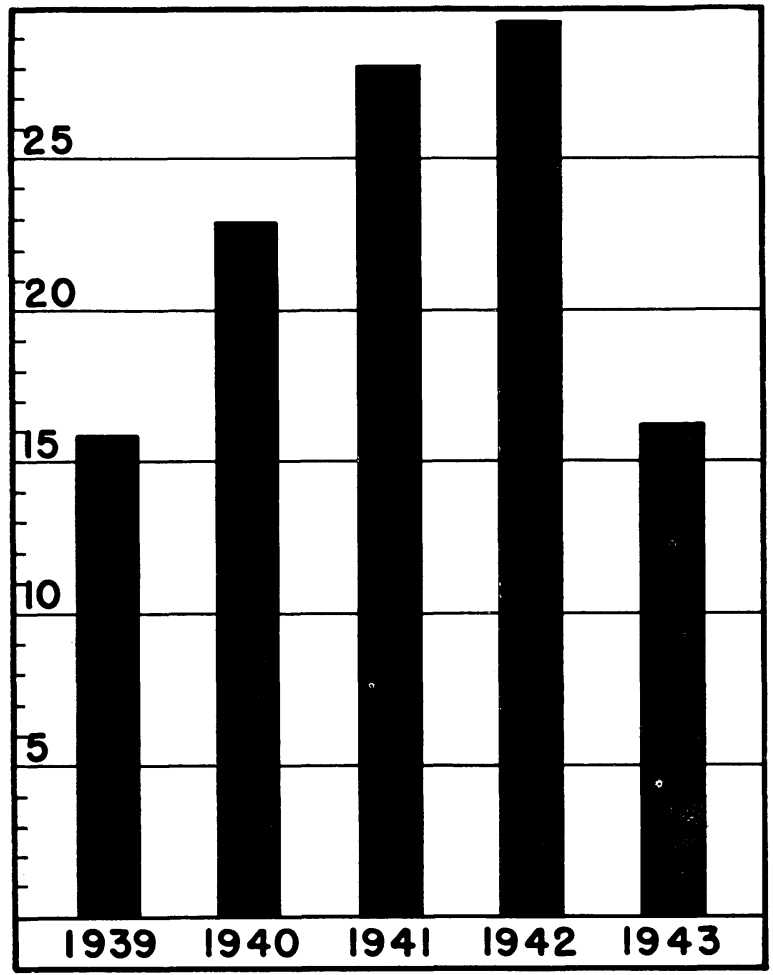

Fig. 64. Annual precipitation at Hays, Kan., 1939 to 1943 , inclusive. The mean annual precipitation is 22.9 inches.
Precipitation increased, at first gradually and then to a remarkable degree. Water content of soil became correspondingly greater, and in other ways conditions for recovery of the greatly depleted vegetation became very favorable.

\section{Precipitation}

The average annual precipitation at the base station, Hays, Kansas, is 22.9 inches. During the 6 years preceding drought it was approximately 5 inches above normal. Throughout the drought years (1933-39) it was below normal every year. The 4 driest years, 1933, 1934, 1936, and 1939, each had approximately 16 inches. Thus, the last year of drought was also one of the most severe (Fig. 64). Precipitation in 1940 was approximately normal, that during the two following years was far above average. It was during these good years that soil moisture was replenished. Upon this reserve the vegetation continued to grow, although not luxuriantly, despite the decreased precipitation in 1943 (16.2 inches).

Precipitation of the growing season (April to September) has a greater effect in promoting growth and recovery of the vegetation than has total precipitation for the year (Fig. 65). June and August were the only months in 1939 with considerable rainfall. In 1940 both May and June had moderate amounts with

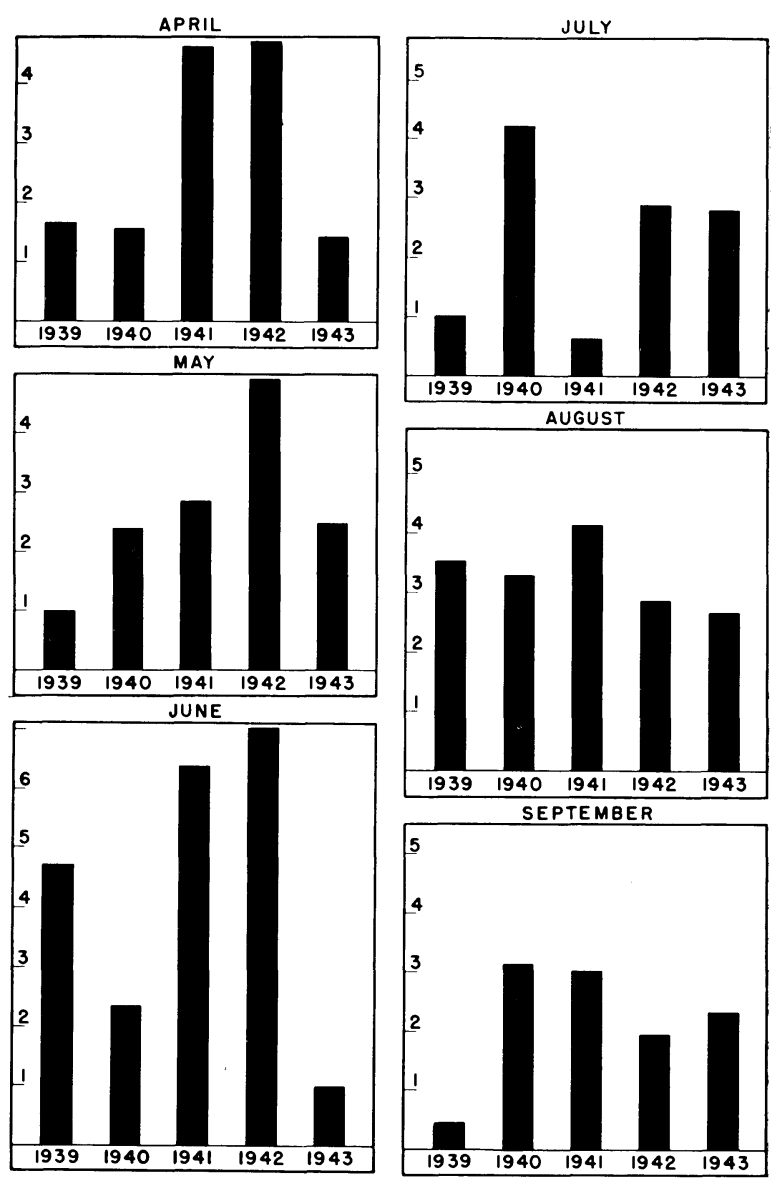

FIG. 65. Rainfall during each month of the growing season at Hays, Kan., from 1939 to 1943 , inclusive. 
good rainfall the three following months. Very heavy rains fell in April, May, June, and August in 194142 , and enough the other months to produce an excellent recovery of vegetation. But in 1943 rainfall was deficient every month of the growing season except September, and especially deficient in June when only an inch of rain fell. Precipitation at more westerly stations is included with tables on recovery. For these conditions were clearly reflected not only in the water content of the soil but also in development of vegetation.

\section{Water Content of SoIL}

The amount of moisture in the soil is especially important in mixed prairie since it is nearly always the limiting factor in plant production. Samples of chernozem soil were taken at Hays, Kansas, from a typical upland silt-loam with a mature profile. The hygroscopic coefficients were approximately 12 to 13 per cent (ef. Albertson 1937). Available water content during the last summer of severe drought (1939) and the four following growing seasons is shown in Figure 66.

There was never any available soil moisture below 6 inches during the extremely dry season of 1939 . Hence the chart showing water content is not extended to a greater depth than two feet, although samples were taken to 5 feet in depth. Available water content in the upper 6 inches was never greater than 10 per cent except during the fourth week of June and the third week of August. Less than 5 per cent was present during 2 weeks of June and less than 10 per cent during the second and fourth weeks of August. It is significant that even with showers as great as 1.5 inches, such as the one received on June 14, comparatively little water was stored in the soil. The explanation of this doubtless lies in the fact that much of a dashing rain of this amount, because of the relatively impervious soil and scarcity of vegetation, is lost by runoff to the soil upon which it falls.

Available water content in 1940 was also almost entirely confined to the first two feet of soil and nearly always to the first 12 inches. This occurred despite the normal annual precipitation since there was no reserve water from 1939. Rainfall by months is shown in Figure 65. No rain fell late in June but more than 4 inches in July. Dry soil occurred in August despite more than 3 inches of rain. Soil moisture was much higher in 1941 (Fig. 66). The soil was constantly moist to 3 feet in May and June, but dry at greater depths. This condition also maintained the first half of July, after which a moderate midsummer drought occurred.

In 1942 a good water content of soil to a depth of 5 feet was usual, but there were exceptions, as in the deeper soil in late summer. But the mixed prairie vegetation grew without interruption and produced a very large yield. Low water content below a depth of 2 feet in fall was not replenished by rains, and in 1943 the available supply was soon completely exhausted. Only an inch of rain fell in June and water was often nonavailable for growth even in the first and second foot (Fig. 66). Recovery was retarded and yields greatly reduced.

Soil moisture by months at Phillipsburg and Dighton during 1939 to 1943 inclusive, is shown in Figure 67. Conditions of soil moisture in 1939 and 1940 were those of drought, and somewhat less favorable than those at Hays. They improved greatly in 1941, and at both stations (unlike Hays) water was usually available to a depth of 5 feet. A good water content of soil, with few exceptions, prevailed at Phillipsburg in 1942. The amount available for growth was somewhat less at Dighton than at either Phillipsburg or Hays. Rainfall was low in May except at Hays. In 1943 there was enough soil moisture to promote good growth at Phillipsburg until August, when drought occurred. Little water was available for growth at Dighton after May and recovery of vegetation was retarded accordingly.

\section{WIND}

Total wind movement in miles per month for the growing season during the years of drought and for each month during the years of recovery is given in Table 8 .

TABLE 8. Average total miles of wind movement per month at Hays, Kansas, during the growing seasons 1933 to 1939 , inclusive. Also wind movement during each month of the growing seasons of 1940 to $1943 .^{1}$

\begin{tabular}{c|c|c|c|c|c|c|c}
\hline \hline Year & April & May & June & July & Aug. & Sept. & Total \\
\hline 1933 to 1939 & 7,693 & 6,692 & 5,989 & 5,853 & 6,048 & 5,961 & 38,236 \\
$1940 \ldots \ldots$ & 7,992 & 6,250 & 6,408 & 6,398 & 4,389 & 5,184 & 36,621 \\
$1941 \ldots \ldots \ldots$ & 7,272 & 5,654 & 5,472 & 4,390 & 4,613 & 6,912 & 34,313 \\
$1942 \ldots \ldots \ldots$ & 7,344 & 7,291 & 5,472 & 5,431 & 5,506 & 5,112 & 36,156 \\
$1943 \ldots \ldots \ldots$ & 6,192 & 6,473 & 7,200 & 5,729 & 5,729 & 5,256 & 36,579 \\
Av. 1940-1943.. & 7,200 & 6,417 & 6,138 & 5,487 & 5,059 & 5,616 & 35,917 \\
\hline
\end{tabular}

1 Data on wind movement and evaporation were obtained from measurements made at Hays, Kansas, by the Division of Dry Land Agriculture, Bureau of Plant Industry, U. S. Department of Agriculture.

Casual examination shows that wind movement each month during drought was very great. It remained high each month in 1940 except August. During the following years it was nearly always less each month and sometimes 1,000 to 1,500 miles less than the average during drought. Exceptions when wind movement was greater occurred in September, 1941, May, 1942, and June, 1943. Total wind movement in 1941, 1942, and 1943 was $3,923,2,080$, and 1,657 miles less, respectively, than the average during drought.

The great dust storms of the drought period and their harmful effects upon grassland have been described (Albertson \& Weaver 1942). In 1940 dust storms were comparatively infrequent. Those that did occur were mostly confined to the western part of Kansas and adjacent territory. In 1941 they were much less frequent than in any of the 7 years preceding, although in March local storms did occur in many counties in the western third of Kansas and in eastern Colorado. In 1943 there was considerable 


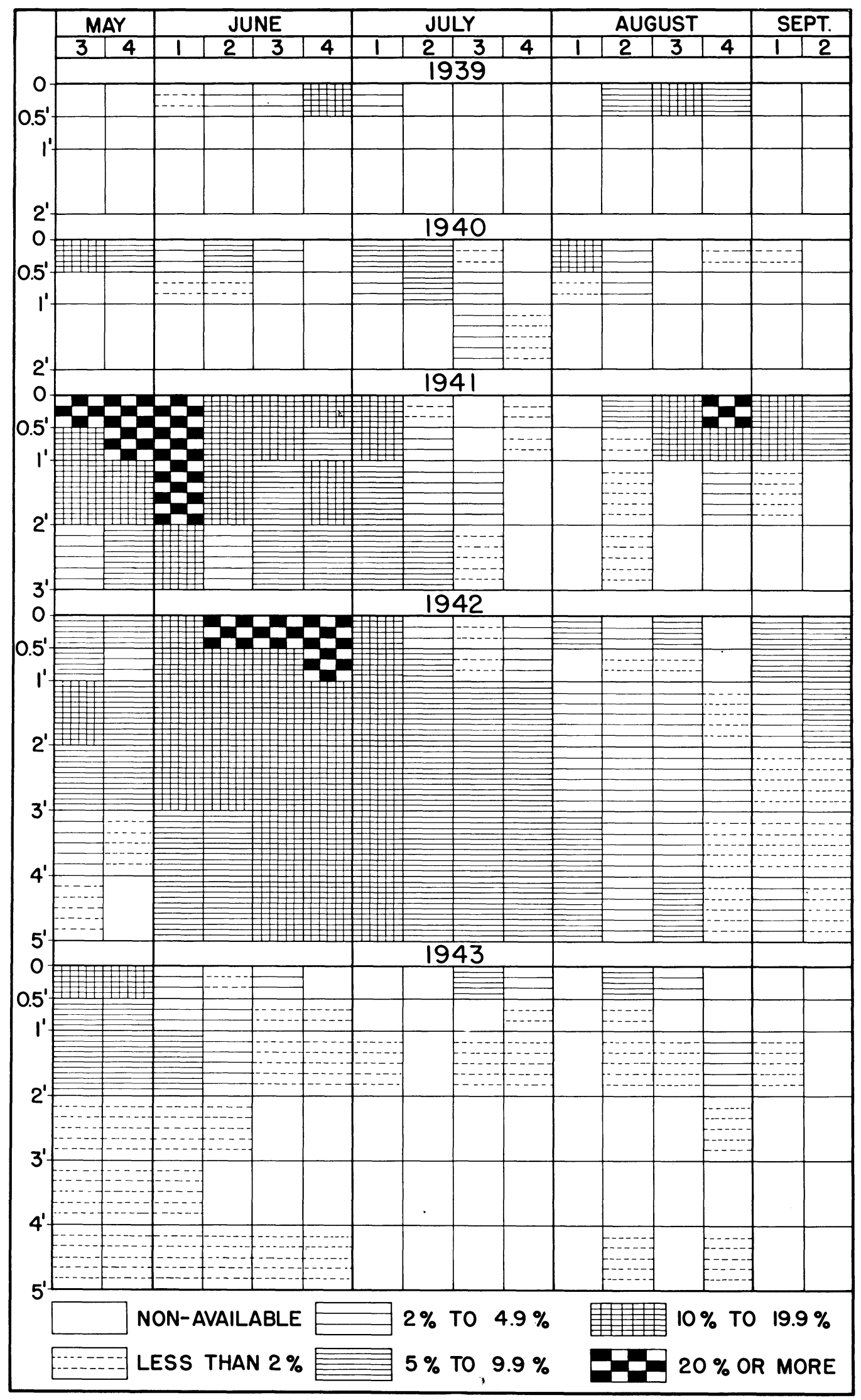

FIG. 66. Available soil moisture to a depth of 5 feet in short-grass (Buchloe-Bouteloua) habitat at Hays, Kan. No water was available for growth below 2 feet during 1939 and 1940, or below 3 feet in 1941 ; hence the deeper soil levels are not shown for these years. 


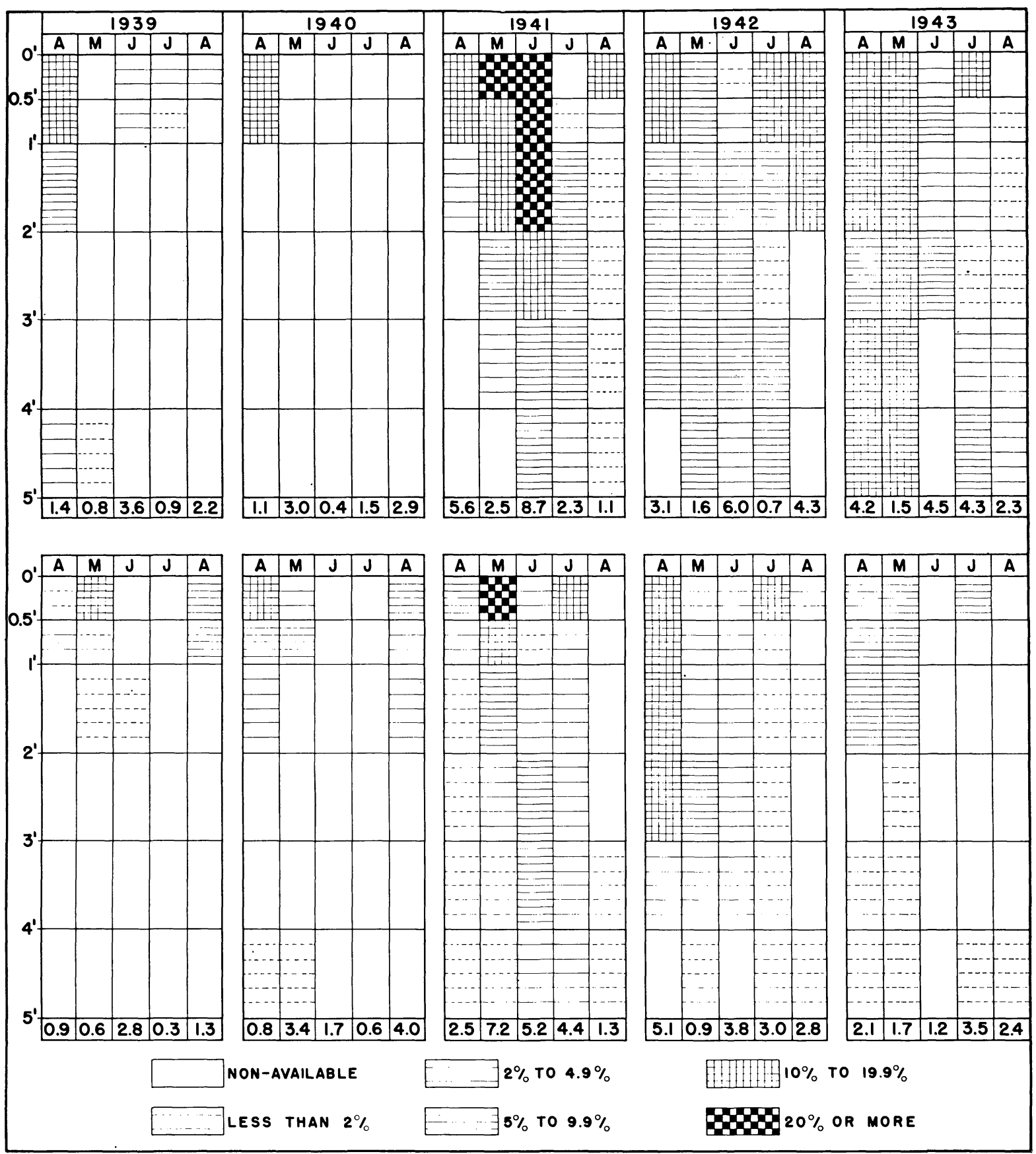

FIg. 67. Available soil moisture each month of the growing season (April to August, inclusive) at Phillipsburg, Kan. (upper panels), and Dighton, Kan. (lower panels). Current monthly rainfall in inches is given at the foot of each column.

wind erosion in the western third of Kansas but dust storms of a local nature occurred only in a few places, some as late as May. But none of these took on the intensity of the black blizzards of 1935 nor were they of such long duration, and the amounts of dust earried by them were eomparatively small.

\section{EVAPORATION}

The average monthly evaporation from a free water surface during the growing season for a period of 7 years (1933 to 1939) gradually increased from 6.6 inches in April to 13.2 in July, after which it decreased to 8.1 inches in September (Table 9). 
TABLE 9. Average monthly evaporation in inches from a free water surface during the growing seasons, 1933 to 1939 , inclusive, at Hays, Kansas. Also, deviation from this average during each of the four following years, and average evaporation during the four years.

\begin{tabular}{c|r|r|r|r|r|r|r}
\hline \hline Year & April & May & June & July & Aug. & Sept. & Total \\
\hline Av. 1933 to 1939 & $\mathbf{6 . 6}$ & 7.5 & 10.2 & 13.2 & 11.3 & 8.1 & 56.9 \\
$1940 \ldots \ldots \ldots$ & -0.8 & +0.2 & +0.2 & -1.7 & -3.9 & -1.7 & -7.7 \\
$1941 \ldots \ldots \ldots$ & -2.8 & -1.2 & -2.8 & -3.5 & -2.4 & -0.5 & -13.2 \\
$1942 \ldots \ldots \ldots$ & -2.0 & -0.6 & -4.1 & -2.9 & -3.1 & -2.3 & -15.0 \\
$1943 \ldots \ldots \ldots$ & +0.3 & -1.6 & -0.3 & -2.9 & -0.2 & -1.7 & -6.4 \\
Av. 1940 to 1943. & 5.3 & 6.7 & 8.5 & 10.5 & 8.9 & 6.6 & 46.5 \\
\hline
\end{tabular}

During 1940 evaporation was slightly higher $(0.2$ inch) in May and June than the average of the drought years. Otherwise it was enough lower each month to reduce the average for the growing season 7.7 inches. In every month of the growing season of 1941 and 1942 water losses by evaporation were reduced 0.5 to 4.1 inches. Total evaporation losses were 13.2 and 15.0 inches less, respectively, than during the drought. In 1943, a year of decreased precipitation, losses were 0.3 inch higher than the drought average for April, but otherwise 0.2 to 2.9 inches lower. Average loss was 6.4 inches below the average for the 7 years of drought.

\section{TEMPERATURE}

The average maximum summer temperatures by months during 1940 to 1943 inclusive, were with few exceptions several degrees lower than the average monthly temperatures during drought. When the mean maximum temperatures by months of the period 1940 to 1943 are compared with those of the drought period, the following decreases are determined for the period of recovery of vegetation: May, $1.3^{\circ}$; June, $2.6^{\circ}$; July, $4.0^{\circ}$; August, $3.9^{\circ}$; and September, $2.6 \mathrm{~F}^{\circ}$. Decreases in mean monthly temperatures in the same order were $1.8^{\circ}, 2.0^{\circ}, 3.0^{\circ}, 2.7^{\circ}$, and $2.3^{\circ}$.

Summarizing, the period of recovery, compared with the preceding one of drought, was one of greatly increased precipitation and soil moisture coupled with lower temperatures, less wind movement, and decreased rates of evaporation. The vegetation reacted to the changed environment by increase in number of species, greater density of cover, and large gains in quantity of forage production.

\section{RECOVERY OF VEGETATION}

Recovery of drought-depleted vegetation in mixed prairie - the central portion of the western range lying west of the ninety-ninth meridian of west longitude and east of the Rocky Mountains-has been fully studied. For despite the dry-land farmer, and much unwarranted exploitation of the prairie sod, the fact remains that the larger portion of this vast grassland has still been untouched by the plow (Great Plains Committee 1936) (Figs. 68 and 69). The importance of livestock production in the United States has but recently assumed the deepest significance of historic time. The highest efficiency in

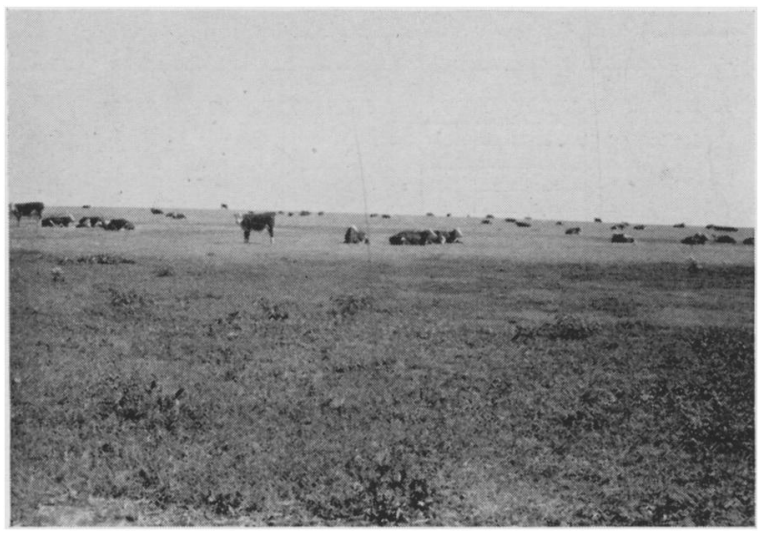

FIG. 68. Range land near Ness City, Kan., illustrative of nearly level lands of the midwest still used only for grazing. Considerable disturbance by dust coverage has occurred in the foreground.

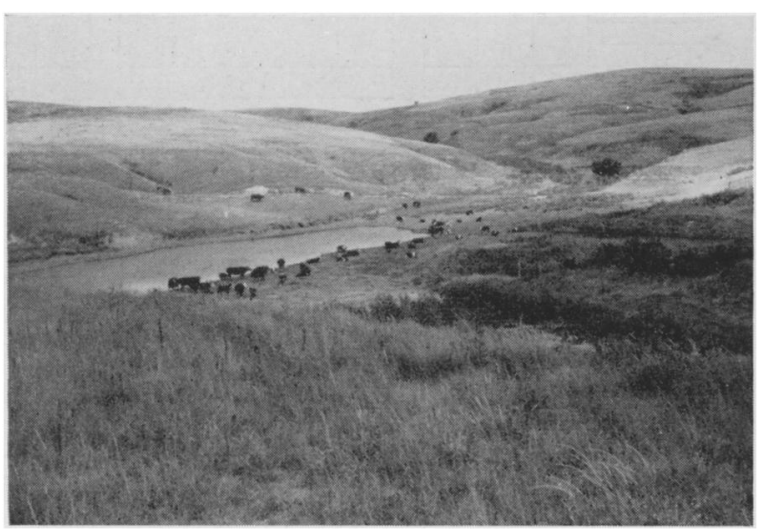

Fig. 69. Range land on steep loess hills near Broken Bow, Neb. It is representative of many square miles of such land east of the sandhills in central Nebraska.

animal production and range management goes hand in hand with the greatest understanding of the range resources (McArdle \& Costello 1936). This must be based on the life history of the vegetation and its response to the environment. During eight years drought had prevailed; on some years the crop of native grasses failed completely and early in drought thousands of cattle either starved or were shipped eastward to new pastures. Any gains made by the vegetation in the period 1933 to 1938 were lost in the terrible drought of 1939-40.

But better times had come. For three summers good rains had fallen, except in 1943 in southwestern Kansas, the Oklahoma and Texas panhandles, southern Colorado and northeastern New Mexico; in short, in the area of the old dust bowl. Even here vegetation had usually made considerable recovery, and the degree of recovery was remarkable where rainfall was ample (Figs. 70 and 71). It had often been moderately good even in the area in or near the dust bowl, except where deep layers of loose soil buried all of the former vegetation. There it is still covered with a stand of annual weeds (Figs. 72 and 73). 


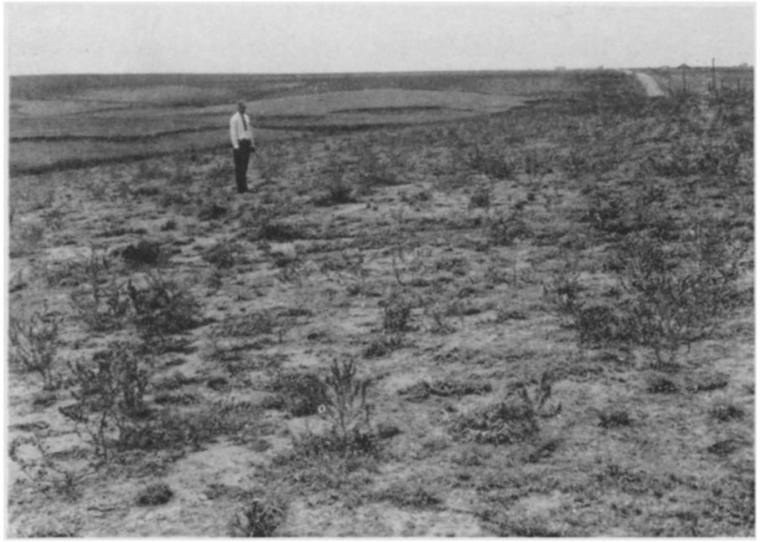

Fig. 70. A much denuded range near Alma, Neb., in 1939 , near the end of the drought.

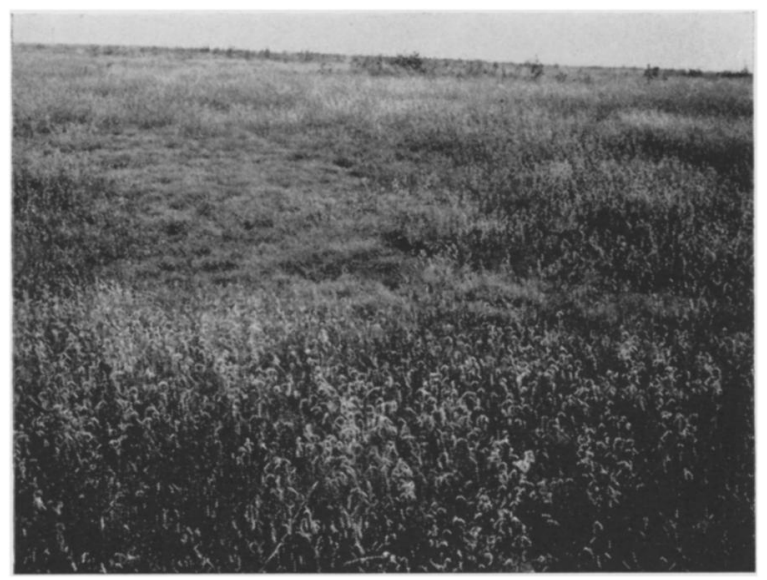

Fig. 71. Appearance of a range at Beardsley, Kan., after two years of good recovery. Buffalo grass forms the mats in the center of the picture and blue grama has an abundance of flowering spikes. August, 1942.

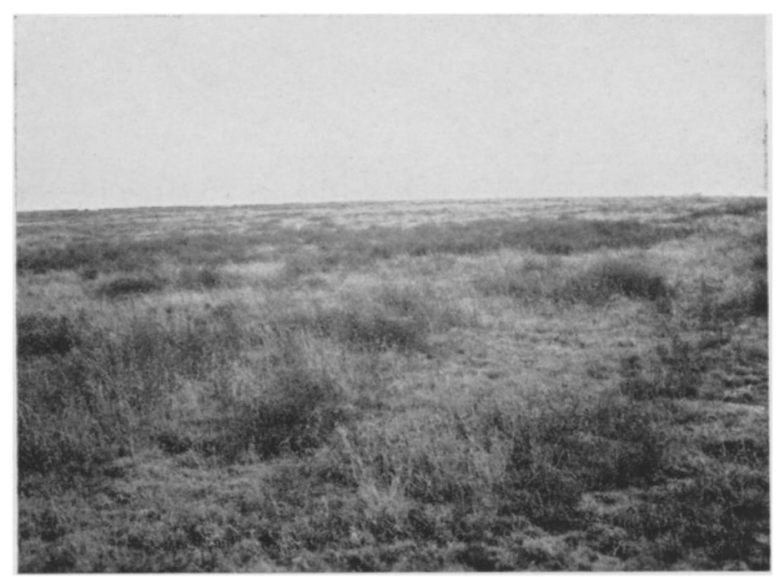

Fig. 72. A range near Quinter, Kan., where partial recovery had occurred in September, 1941. The weeds (dark color) are mostly Russian thistle; they alternate with open patches of blue grama and buffalo grass.

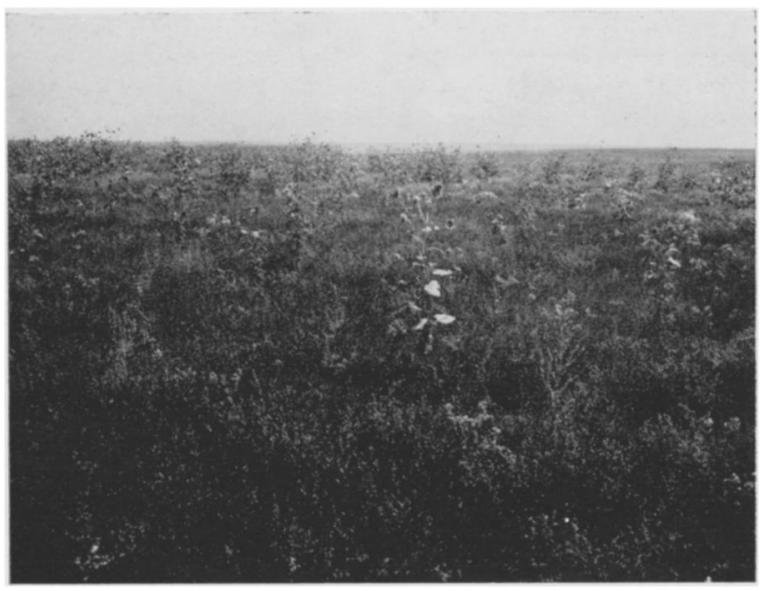

Fig. 73. Range near Kendall, Kan., which was thickly covered with dust in which grew a dense stand of Russian thistle, annual sunflower, and other weeds. There is practically no grass. August, 1941.

The ranges of western Kansas were not fully stocked in 1941 to 1943 , inclusive, a condition which maintained in many places elsewhere. Although emphasis was placed on the production of more cattle, the herds had been so greatly depleted that, in general, the renewed cover increased more rapidly than the stock. In most of the ranges probably not more than half of the forage was utilized, and frequently only 10 to 20 per cent. Some, of course, were overgrazed; in others none of the vegetation was removed. The ranges would probably have increased their perennial cover even more rapidly if moderate grazing had been generally employed and much of the foliage which later formed excess debris had been consumed or trampled to the ground.

The major features of recovery were closely connected with the behavior of three grasses, although there were several minor ones. These were buffalo grass (Buchloe dactyloides), blue grama (Bouteloua gracilis), and sand dropseed (Sporobolus cryptandrus). Before the drought the first two of these, the short grasses, were fairly evenly intermixed over most of western Kansas, eastern Colorado, and western Nebraska.

Buffalo grass entirely disappeared from some ranges; in others it remained alive only in the most favorable places as regards water supply. This occurred over thousands of square miles of land in the dust bowl. In addition this grass disappeared from the level areas of hundreds of other pastures eastward and northward. Conversely, many ranges retained occasional tufts or small sodded patches, and it was from these that regeneration proceeded so rapidly when the soil again became moist.

Blue grama is much more drought resistant than buffalo grass and it was never killed so uniformly nor so completely over a wide area. In nearly every range, unless deeply buried by dust, some bunches of blue grama persisted. These drought relicts often increased greatly in diameter (sometimes to 10 or 12 
inches), and were found scattered thinly in pastures where no other perennial vegetation survived.

Sand dropseed occurred widely but usually not abundantly before the drought, except in sandy soil. But when the silt loams and other types of hardland soils became bare and warm the tiny windblown seeds of this drought resisting bunch grass were spread everywhere and plants often occurred abundantly. They persisted tenaciously, even where much dwarfed by drought.

Rate of recovery of vegetation varied greatly from place to place, since several conditions were involved. Chief among these were the kind of original vegetation, the intensity of drought and consequent degree of depletion, and the kind of grass relicts at the end of the drought. Other factors were the amount of damage resulting from burial by dust and the intensity of grazing and trampling during the period of recovery, as well as the distribution of precipitation over various portions of the area during recovery. Thus, the process far from being simple was actually considerably involved.

\section{Examples OF Recovery}

A principle that held true throughout was that recovery was always slower where blue grama alone remained than where buffalo grass was the sole perennial grass or where it occurred with blue grama. This is well illustrated by the slow recovery of a range near Tribune, Kansas. The cover following the drought of 1939 was only 6 per cent. Nearly all was blue grama with a trace of sand dropseed. It increased continuously but slowly year after year. The percentages of blue grama (1940 to 1943) were 5.4, 13,18 , and 21 respectively. Sand dropseed, which entered the quadrats in 1939, added a small increment, which increased to 6 per cent, making a total basal cover of 27 per cent after the three years of recovery (Fig. 74). In another range a few miles distant, blue grama increased from 2.2 to 15 per cent in the same period.

That buffalo grass spreads much more rapidly than blue grama is well illustrated by quadrats in a dustcovered pasture near Kendall, Kansas. In 1941, buffalo grass composed 1.7 per cent of the very sparse cover. But it increased to 34 per cent the next year and to 47.4 in 1943 . During this period blue grama increased from 1 to only 3 per cent, as did also sand dropseed (Fig. 75). On a range near Marienthal, Kansas, which was only lightly pastured after being heavily dusted, buffalo grass increased its basal cover (1940 to 1943) as follows: 1.7, 23.7, 84.5, and 93.4 per cent. Increase of blue grama was slow, in the same period of years; from 0.9 to 4.8 per cent. Thus, this wonderful recovery was due almost entirely to buffalo grass.

Revegetation from a poor cover of mixed short grasses is well illustrated by quadrats in a pasture near Quinter. This range had been grazed by sheep rather continuously since 1937 and was closely grazed in 1942-43. The basal cover was composed entirely of the two short grasses. They were equally abun- dant both in 1940 (total basal cover 7.8 per cent) and 1941 (24.6). Blue grama increased to 28 per cent in 1942, but decreased to 16 the next year. But buffalo grass increased first to 47 per cent and then to 79. Thus, in three years, despite the grazing, recovery resulted in a 95 per cent cover of short grass (Fig. 76).
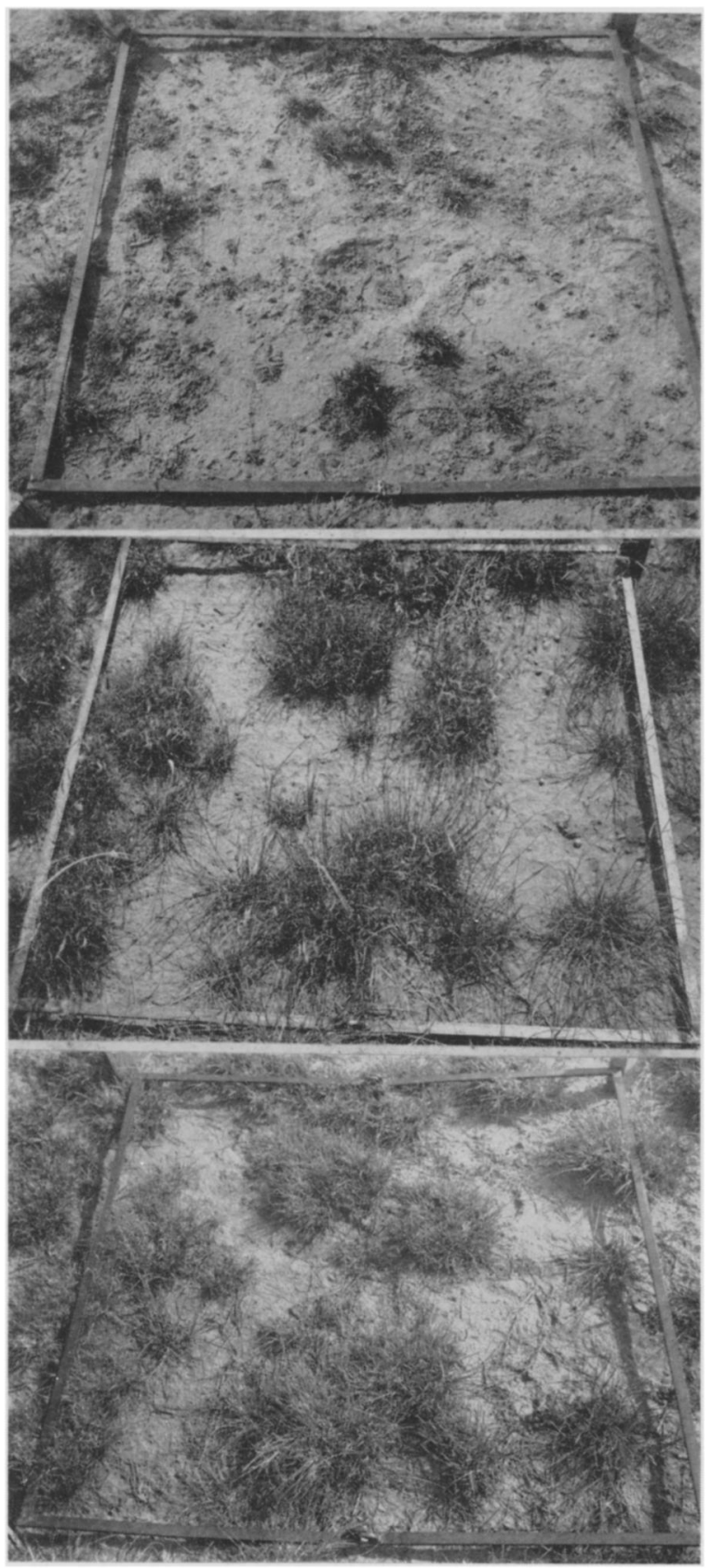

Fia. 74. A typical quadrat in a large range near Tribune, Kan. In the fall of 1940 the grass was all blue grama with a basal cover of 5.4 per cent (upper). The same quadrat in 1942 (middle) with 18 per cent blue grama and 11 per cent sand dropseed. After 3 years of recovery (lower) there was only 21 per cent basal cover of blue grama. 
An example of a more rapid recovery where dusting had been less extensive but drought equally severe is taken from another pasture near Quinter. Here grazing was moderate. Increase of blue grama was slow from 1940 to 1943 . The percentages of cover were $6,12,13$, and 16 , respectively. Buffalo grass developed very rapidly from 2 per cent in 1940 to
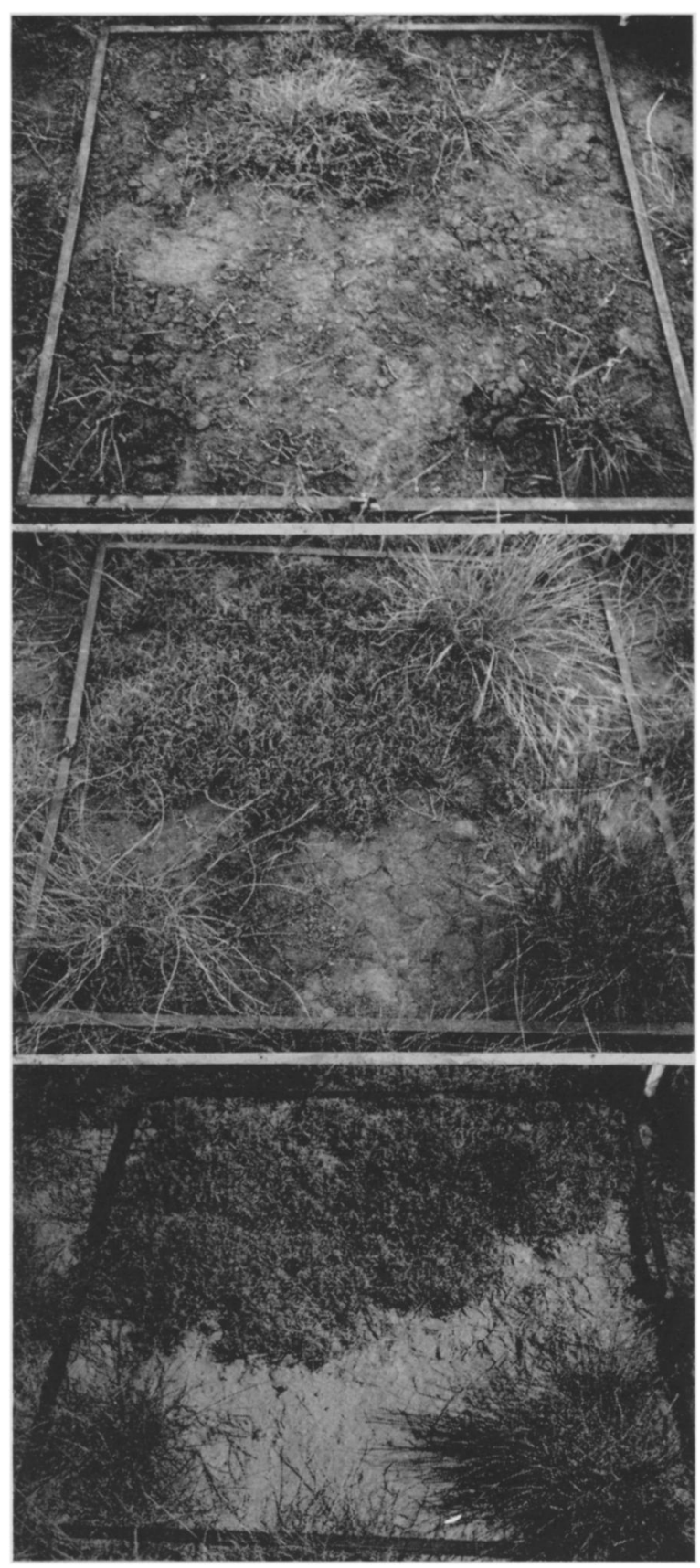

Fig. 75. Typical quadrat on dusted range near Kendall, Kan. The original cover was almost entirely destroyed. Only fragments (about 2 per cent) of the short grasses remained in 1941 (upper). By 1942 (middle) buffalo grass had increased to 34 per cent basal cover, and in the fall of 1943 (lower) it composed 47 per cent.
34 a year later. It then increased its basal cover to 52 and finally to 80 per cent. Thus, the total cover year by year (including a little sand dropseed which entered in 1941) was 8, 46, 66, and 98 per cent, a remarkably early recovery (Fig. 77 ).

Where sand dropseed entered the range early (1937) it frequently played an important part in recovery. In this example near Quinter, the topography was quite rolling and the soil a sandy loam,
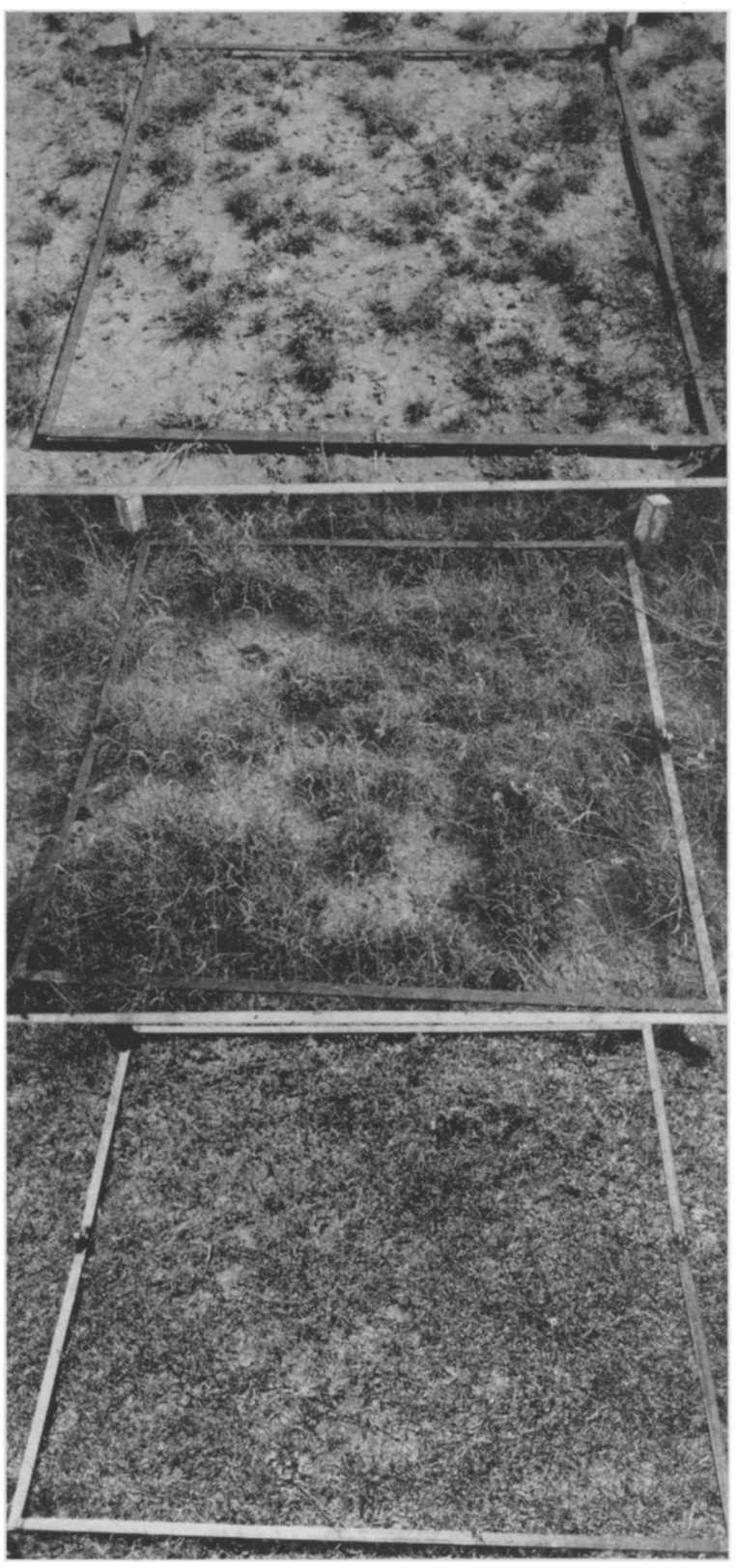

Fig. 76. A mixed cover of blue grama and buffalo grass in a sheep range near Quinter, Kan. In 1939 the basal area was 22 per cent, but it decreased to 8 (upper) in 1940. By 1941 (middle) when the two grasses were equally abundant, the cover was 25 per cent. It increased to 95 per cent in 1943 (lower), but it was more than four-fifths buffalo grass. 

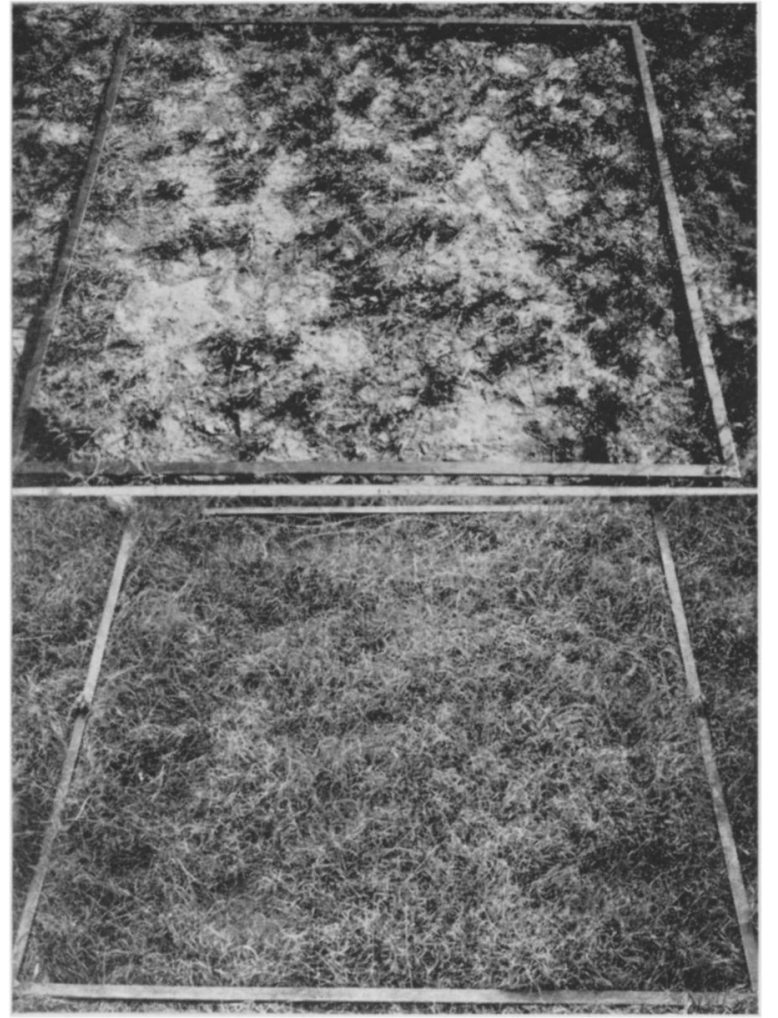

Fig. 77. Increase in two years, in a range near Quinter, from a basal cover of 8 per cent to one of 66 per cent. Buffalo grass composed one-fourth of the vegetation in 1940 (upper) but 80 per cent in 1942 (lower).

conditions most favorable for this species. There was a fairly good cover of short grasses in 1939 but this bunch grass became only moderately abundant (Fig. 78). It decreased to 0.5 per cent in 1940 but was 12 in 1943. Blue grama increased from 1.6 to 18 , but buffalo grass from 1 to 32 per cent. Thus the basal cover was 62 per cent, an increase of about eightfold.

Recovery on ranges with drifted soil was determined largely by the amount, if any, of relict vegetation. Occasionally it was rapid, usually there was a wilderness of annual weeds for a long time (Fig. 79).

\section{Recovery in Ungrazed Buchloe-Bouteloua TYPE}

The increase in cover and changes in its composition have been ascertained each year since 1932 in a range near Hays, Kansas. Quadrats were marked out in 1932 after cattle were excluded. The grass had been subjected only to moderate grazing and had been protected from stock by a large exclosure (Albertson \& Weaver 1942). Hence, changes since that time may be attributed solely to environment.

In 1932 buffalo grass and blue grama occurred in a mixed stand of about equal amounts and together formed a cover with a basal area of 88.6 per cent. Losses of buffalo grass were greater than those of blue grama after 1934, but it recovered in 1938 .

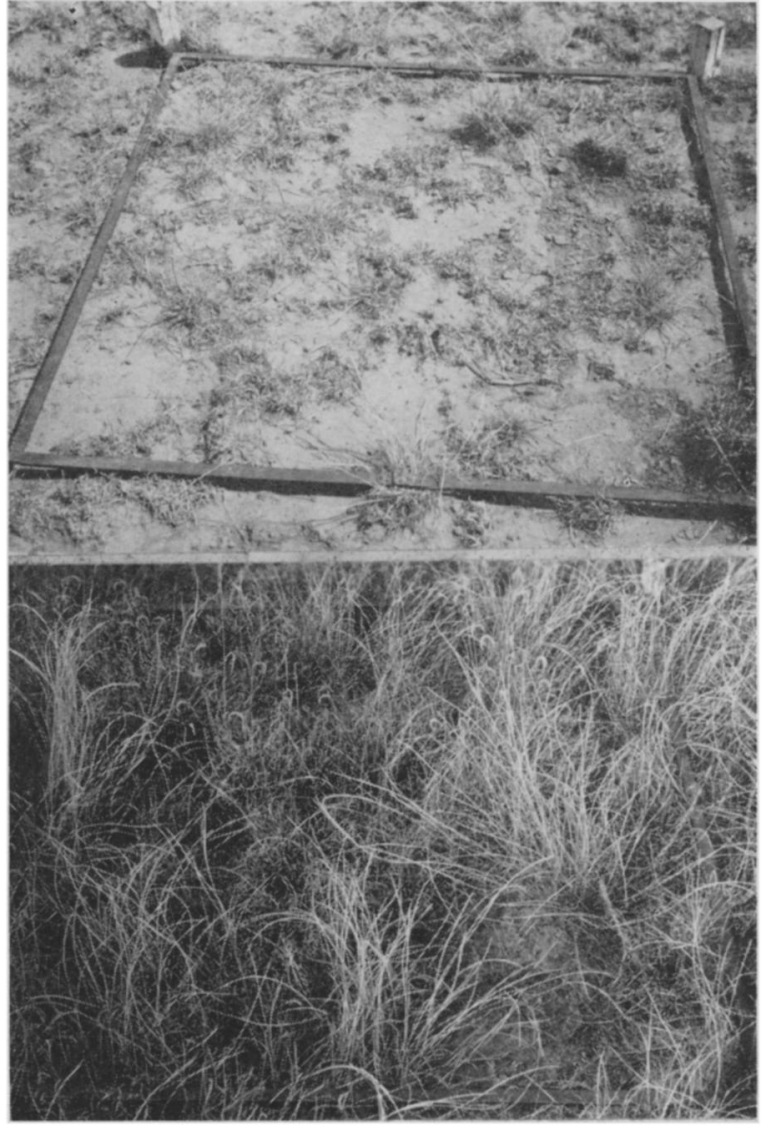

Fig. 78. Quadrat in a range near Quinter where sand dropseed became an important component of the recovering vegetation. It composed 6 of the 19 per cent basal cover in 1939 (upper), decreased to 0.5 per cent the next year, but covered an area of 7 per cent in the greatly improved cover in 1941 (lower).

Hence in 1938 the two dominants again occurred in approximately equal amounts, but each had a basal cover of only 15 per cent. After the severe fall and winter drought of 1939-40 blue grama was once more somewhat the more abundant. But during the following period of recovery blue grama merely doubled in amount, while buffalo grass increased sevenfold (Table 10).

TABLE 10. Change in percentage of basal cover in 10 meter quadrats in typical areas of the ungrazed BuchloeBouteloua type at Hays, Kansas.

\begin{tabular}{|c|c|c|c|c|c|}
\hline Species & 1939 & 1940 & 1941 & 1942 & 1943 \\
\hline $\begin{array}{l}\text { Bouteloua gracilis. . . . . . } \\
\text { Buchloe dactyloides . . . }\end{array}$ & $\begin{array}{r}13.0 \\
9.3\end{array}$ & $\begin{array}{r}10.3 \\
9.2\end{array}$ & $\begin{array}{l}13.9 \\
41.3\end{array}$ & $\begin{array}{l}14.9 \\
79.8\end{array}$ & $\begin{array}{l}21.8 \\
65.9\end{array}$ \\
\hline Total. & 22.3 & 19.5 & 55.2 & 94.7 & 87.7 \\
\hline
\end{tabular}

That recovery was very rapid in 1941-42 is apparent. During the following summer of decreased rainfall there was a slight loss in the total cover. Since blue grama increased by about one-third, the loss was entirely that of buffalo grass. 


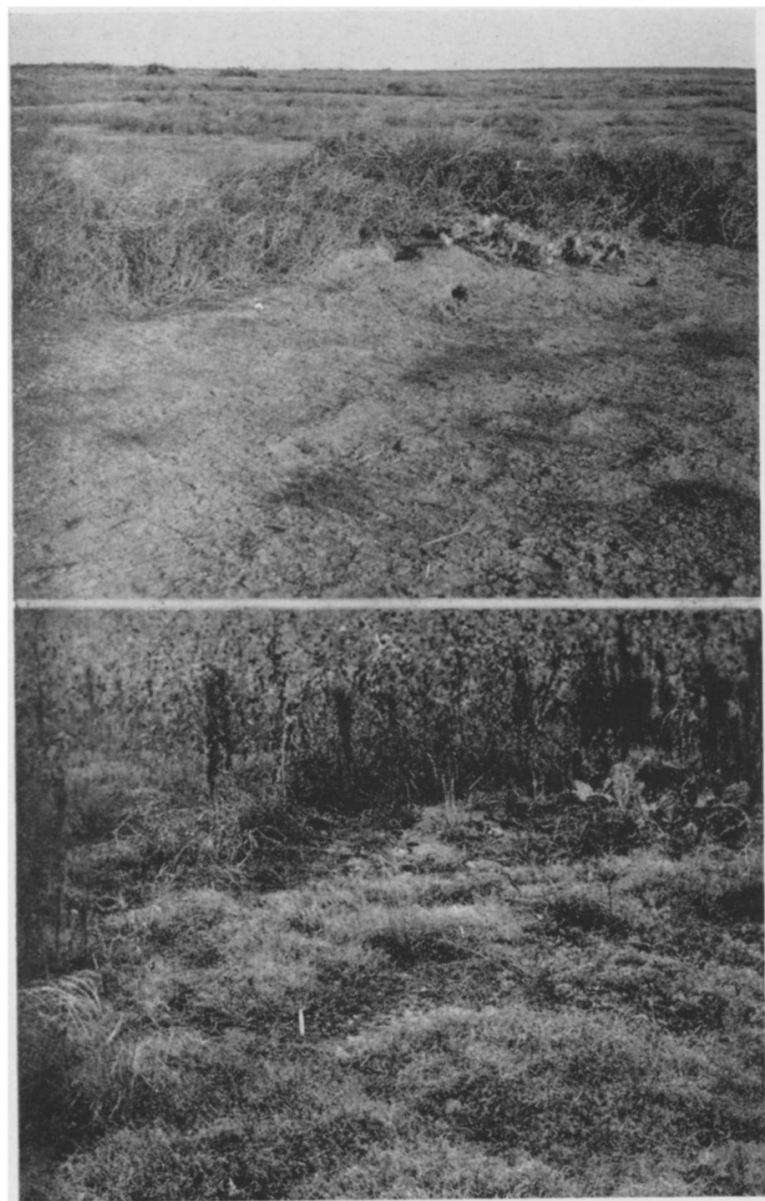

Fig. 79. A range with drifts of soil populated with Russian thistles; note the eactus with pack rat burrows beneath it (upper). April 11, 1941. The dead Russian thistles have been blown into windrows. There were only a few remnants of buffalo grass. From these the grass spread so rapidly that in spots a cover of 20 per cent had been established in 1942. The lower view is of the foreground of the upper one in 1942. Note cover of buffalo grass. On other ranges where there were no relicts, annual weeds prevailed throughout.

\section{Recovery in Moderately Grazed Buchloe- Boutelova TYPE}

In the spring of 1935 meter quadrats were also staked and charted in representative portions of a moderately grazed range. This was during the drought, but the total basal cover was still 49.2 per cent, all but 0.1 per cent being composed of the two short grasses. Thereafter there was a decrease and only 27.8 per cent cover remained in 1939. As shown in Table 11, this was rather equally distributerl between the two dominants.

Increase in total cover was much less in 1943 than the very rapid recovery during the two preceding years. Buffalo grass was so aggressive that it continued to spread somewhat at the expense of blue grama, a phenomenon that occurred elsewhere under rapid recovery but which is undoubtedly only tem-
TABLE 11. Change in basal cover in 10 meter quadrats in moderately grazed Buchloe-Bouteloua type at Hays, Kansas.

\begin{tabular}{c|r|r|r|r|r}
\hline \hline Species & 1939 & 1940 & 1941 & 1942 & 1943 \\
\hline Bouteloua gracilis...... & 14.4 & 18.2 & 22.8 & 29.0 & 22.3 \\
Buchloe dactyloides .... & 12.3 & 8.3 & 19.9 & 42.2 & 53.4 \\
Sporobolus cryptandrus. & 1.1 & 1.1 & .5 & .1 & .1 \\
Aristida longiseta...... & $\ldots .$. & $\ldots$. & $\ldots$. & $\ldots$. & .1 \\
\cline { 2 - 4 } Total........... & 27.8 & 27.6 & 43.2 & 71.3 & 75.9 \\
\hline
\end{tabular}

porary. Broken cover permitted the entrance of sand dropseed in 1935; it decreased to a trace as the short grasses covered more and more of the soil. These results illustrate the widely recognized fact that moderate grazing is no great handicap to normal development of the short grasses. Indeed, under normal precipitation moderate grazing results in a more uniform cover than that developed under total protection (Savage 1939).

\section{Recovery in Overgrazed Buchloe-Bouteloua TYPE}

Studies of an overgrazed short-grass type were pursued concurrently with those of one moderately grazed. The average basal cover in the early years of drought (1935) was 22.1 per cent. Blue grama constituted 9 per cent and buffalo grass 12 (Albertson \& Weaver 1942). Cover decreased after quadratting in 1939 from 19.4 to 13.6 per cent. Increase thereafter was rapid, to 59 per cent in 1941 , and to 93 the next year. This basal area was maintained in 1943 (Table 12).

TABLE 12. Change in percentage of basal cover in 7 meter quadrats in an overgrazed Buchloe-Bouteloua type at Hays, Kansas.

\begin{tabular}{|c|c|c|c|c|c|}
\hline Species & 1939 & 1940 & 1941 & 1942 & 1943 \\
\hline $\begin{array}{l}\text { Bouteloua gracilis. . . . . . } \\
\text { Buchloe dactyloides. . . } \\
\text { Bouteloua curtipendula. } \\
\text { Triodia pilosa. . . . . . . } \\
\text { Sporobolus cryptandrus. }\end{array}$ & $\begin{array}{r}10.0 \\
8.3 \\
.4 \\
.4 \\
.3\end{array}$ & $\begin{array}{r}7.3 \\
6.1 \\
\ldots \ldots \\
\cdots . \\
.2\end{array}$ & $\begin{array}{r}17.7 \\
40.9 \\
\ldots \\
\cdots \\
.1\end{array}$ & $\begin{array}{r}7.2 \\
85.9 \\
\cdots \\
\cdots \\
.2\end{array}$ & $\begin{array}{r}15.1 \\
78.2 \\
\ldots \ldots \\
\cdots \\
.5\end{array}$ \\
\hline Total. . & 19.4 & 13.6 & 58.7 & 93.3 & 93.8 \\
\hline
\end{tabular}

The astounding increase of buffalo grass from 6.1 per cent cover in 1940 to 85.9 two years later was not unusual. This occurred somewhat at the expense of blue grama which merely doubled its basal area during the three years. Although sand dropseed was present it was inconsequential. This species if previously firmly established occurred in a newly developed cover, but it has never been found to invade one that was well established.

A continuous record of the degeneration of the Buchloe-Bouteloua type where it was ungrazed, moderately grazed, and overgrazed has been obtained since 1932. This, with the data on recovery, is shown by means of graphs in Figure 80 . During drought 


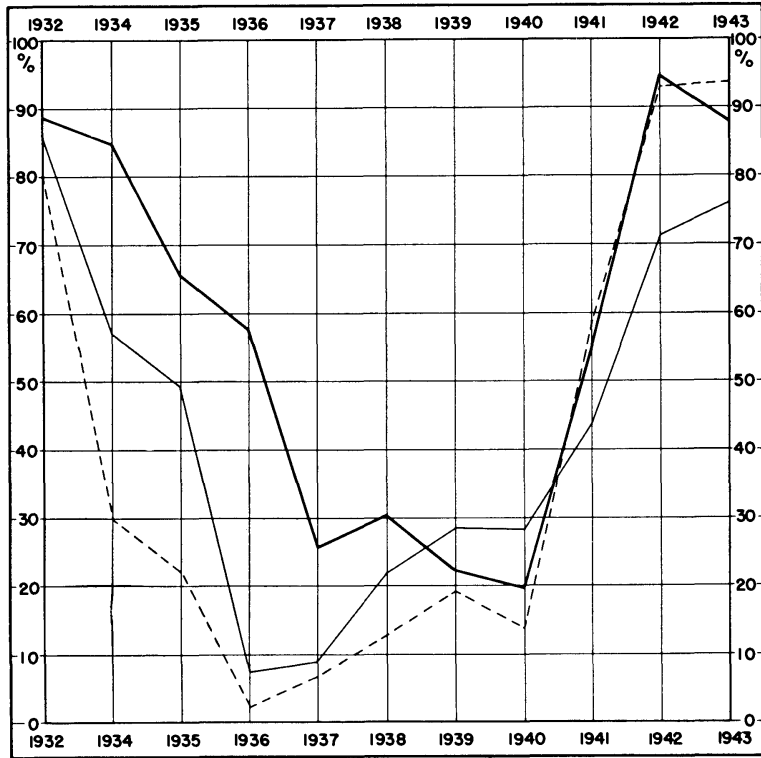

Fig. 80. Decrease in percentage of basal cover in the short-grass type during drought and increase during recovery after drought: ungrazed (heavy line), moderately grazed (light line), and overgrazed (broken line).

the average basal cover on the area ungrazed since 1932 was better than that of the moderately grazed one, except in 1939. The cover in the overgrazed area was correspondingly lower than that of the moderately grazed one. Thus, the degeneration of the range showed a direct relation to the degree of grazing. Studies made in the spring of 1940 showed that losses in autumn and winter on the ungrazed area far exceeded those of ranges that were moderately grazed or overgrazed. This was due to the fact that in the ungrazed pasture the cover was considerably taller and thicker than elsewhere. It used the available water more rapidly than vegetation moderately or closely grazed and this resulted in greater loss by death during this very dry time. The same phenomenon occurred again in 1943. The lag in recovery of the moderately grazed pasture after 1940 was caused by a dense stand of little barley which greatly retarded the development of the short grasses. In examining these graphs it should be kept in mind that the area above the individual graph indicates bare soil or bare soil more or less covered with annual weeds. It is of interest that the high losses in cover sustained during the 8 years of drought were restored in a period of 3 good years, largely because of the wonderful recuperative powers of buffalo grass.

Reconery in the Andropogon Scoparius Type

Quadrats in the little bluestem type were established in 1932 when stock was excluded from several representative areas. The vegetation had been moderately grazed for many years. The quadrats were charted in the fall of 1932 and each subsequent year. Two types, one of a closed and one of an open cover of vegetation, were studied. In the closed type, which elothed the moderately deep soil overlying the limestone, the basal cover was about 60 per cent and entirely of little and big bluestem. The most common vegetation on the brows of the hills, where the underlying rock is at or near the surface, was of the openbunch type with a basal cover of about 25 per cent. In the closed type the dense foliage so completely shaded the interspaces that few other species occurred until the cover was opened by drought. Some increase in the cover beyond 60 per cent was found where grazing had been heavy enough to prevent accumulation of excessive debris but not so intense as to damage the bluestems. Less than 60 per cent cover was frequently found due to excessive debris which had accumulated during previous years. Conversely, in the open type there were usually scattered tufts of little bluestem, hairy grama (Bouteloua hirsuta), and hairy dropseed (Sporobolus pilosus), with a considerable sprinkling of dwarfed forbs in the well-lighted open spaces between the bunches. Recovery in the elosed type is shown in Table 13.

TABLE 13. Change in percentage of basal cover in 15 meter quadrats in an ungrazed, elosed type of Andropogon scoparius at Hays, Kansas.

\begin{tabular}{|c|c|c|c|c|c|}
\hline Species & 1939 & 1940 & 1941 & 1942 & 1943 \\
\hline $\begin{array}{c}\text { Andropogon scoparius.. } \\
\text { A ndropogon furcatus... } \\
\text { Bouteloua curtipendula } \\
\text { Bouteloua gracilis..... } \\
\text { Bouteloua hirsuta...... } \\
\text { Sporobolus pilosus.... } \\
\text { Buchloe dactyloides.... } \\
\text { Schedonnardus } \\
\text { paniculatus......... } \\
\text { Agropyron smithii..... }\end{array}$ & $\begin{array}{r}.6 \\
2.2 \\
17.6 \\
8.8 \\
.3 \\
.4 \\
.3\end{array}$ & $\begin{array}{r}.5 \\
6.6 \\
6.9 \\
\ldots .1 \\
.1 \\
.7\end{array}$ & $\begin{array}{r}.2 \\
10.4 \\
6.4 \\
\ldots . \\
.1 \\
1.4\end{array}$ & $\begin{array}{r}.9 \\
25.9 \\
12.7 \\
.1 \\
.1 \\
4.4\end{array}$ & $\begin{array}{r}3.1 \\
26.8 \\
8.6 \\
.2 \\
.1 \\
8.0\end{array}$ \\
\hline Total... & 30.2 & 14.8 & 18.5 & 44.1 & 47.4 \\
\hline
\end{tabular}

In 1939 the basal cover was only half as great as before the drought. It contained the last remnants of little bluestem. It was again reduced one-half by 1940. Great recovery occurred in 1942 and slightly more the following year. The recovery was not due to spreading of the original codominant, big bluestem, but in the main to an increase of side-oats grama from 6.6 to 26.8 per cent. This species thrived even in rather dry soil when competition was decreased. Bouteloua gracilis had invaded the quadrats in 1934 and increased to 8.8 per cent in 1939 , an abundance exceeded only in 1942. But Buchloe dactyloides, which apeared in 1938 (.1 per cent), increased steadily in 1942-43. The appearance of Schedonnardus and Agropyron in 1943 is of interest. But the complete change from postclimax bluestem vegetation to mixed prairie with the two grama grasses and buffalo grass as dominants is of profound significance.

Recovery in the ungrazed open type of little bluestem is shown in Table 14.

Andropogon scoparius decreased more slowly here during drought than in the closed type. It retained 5.6 per cent cover in 1939 and even the remnants left in 1940 increased sixfold, largely a recovery of dormant crowns. Due to the sparseness of vegetation 
TABLE 14. Changes in percentage of basal cover in 4 meter quadrats in ungrazed open type of Andropogon scoparius at Hays, Kansas.

\begin{tabular}{|c|c|c|c|c|c|}
\hline Species & 1939 & 1940 & 1941 & 1942 & 1943 \\
\hline $\begin{array}{l}\text { Andropogon scoparius... } \\
\text { Bouteloua curtipendula. } \\
\text { Bouteloua hirsuta. . . . . } \\
\text { Andropogon furcatus... } \\
\text { Sporobolus pilosus. . . . }\end{array}$ & $\begin{array}{r}5.6 \\
11.1 \\
1.2 \\
.2\end{array}$ & $\begin{array}{r}.4 \\
8.8 \\
.8 \\
.1 \\
.6\end{array}$ & $\begin{array}{r}.8 \\
19.3 \\
1.1\end{array}$ & $\begin{array}{r}2.2 \\
25.3 \\
5.5\end{array}$ & $\begin{array}{r}2.4 \\
22.3 \\
3.6 \\
\cdots .4\end{array}$ \\
\hline Total. & 18.1 & 10.7 & 21.5 & 34.0 & 28.7 \\
\hline
\end{tabular}

and the mulch of partially disintegrated fragments of limestone, it seems probable that depletion of soil moisture through transpiration and evaporation from the soil surface occurred more slowly than from the more densely populated deeper soil of the closed little bluestem type. Side-oats grama entered the area in 1934 and, although somewhat depleted in 1940, formed most of the cover in 1943. Neither big bluestem (except a trace), blue grama, nor buffalo grass occurred. Bouteloua hirsuta, present throughout the 11 years, exceeded little bluestem in amount. Thus, while the cover was more extensive after than before the drought, the change was from the postclimax to a xeric mixed prairie type.

A continuous record of the degeneration of the ungrazed and overgrazed Andropogon scoparius type together with its recovery is shown by graphs in Figure 81. Data are from a different lot of quadrats than those given in Table 14. The complete ungrazed cover in 1932 was 60 per cent. The first low points were reached in 1936 when only about 16 and 9 per cent cover remained in the two types respectively. The year 1939 was the driest of all, and the basal cover produced the previous year was sustained largely by

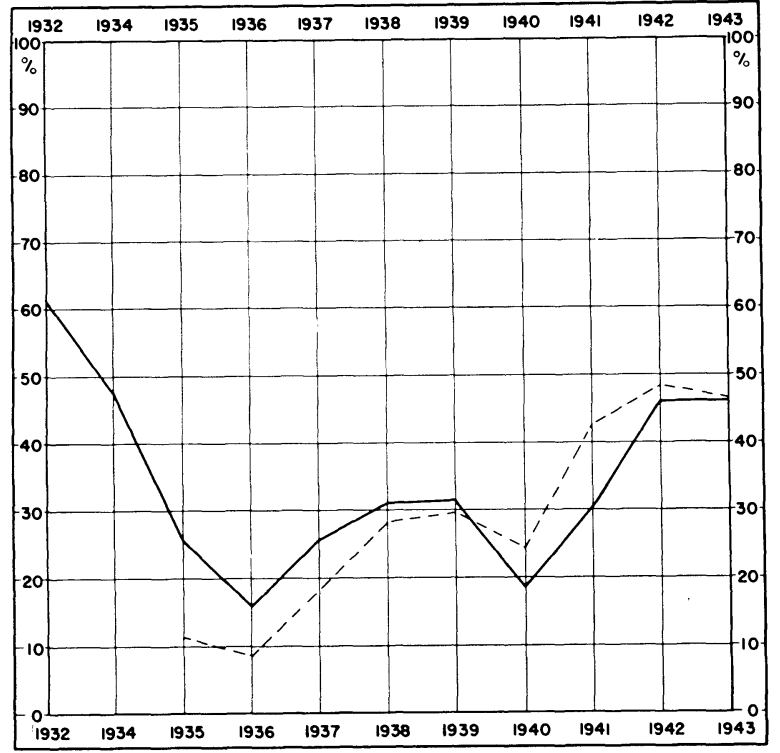

Fig. 81. Graphs showing the percentage of basal cover during the several years of drought and recovery in the Andropogon scoparius type. Ungrazed shown by heavy line and overgrazed by broken line. the reserve of soil water received in 1938. Little bluestem, which furnished the major portion of vegetation at the beginning of the drought, rapidly decreased to practically nil in 1939 . Hence, the story of recovery is almost entirely that of change in amount of side-oats grama and blue grama, which in 1939 furnished the bulk of the basal cover in ungrazed pasture. These grasses with buffalo grass furnished 24 of the 29 per cent cover in the overgrazed pasture, where little bluestem was almost extinct. The more rapid recovery of the overgrazed than the ungrazed pasture was due to a larger percentage of short grasses, especially buffalo grass, in the overgrazed range.

In examining the graphs, it should be understood that the area above each graph indicates bare soil or at least soil without a cover of perennial grasses. The normal basal area in this type was only about 60 per cent, hence by 1943 a cover only about 15 per cent below normal was reestablished, but one in which little bluestem composed a relatively small part.

\section{Recovery in Litthe Bluestem-Short Grass Mixture}

The predrought transition from short grasses on the level hilltops with deep soil to little bluestem in the shallower soils overlying the limestone was very abrupt in many places. In fact a part of each type could be included in a single square meter. But more usually the little bluestem was scattered widely in bunches among the short grasses. In the autumn of 1932, the average basal cover in quadrats located where there was a relatively large amount of little bluestem was 65 per cent. The percentage of little bluestem was 40, but this grass disappeared by 1938 . Short grasses originally composed 21 per cent of the cover and big bluestem the remainder (4.5 per cent). The low ebb of the grass population in 1939-40 and recovery thereafter is shown in Table 15.

TABLE 15. Change in percentage of basal cover in 10 meter quadrats in an ungrazed area in the ecotone between short grass and little bluestem at Hays, Kansas.

\begin{tabular}{r|r|r|r|r|r}
\hline \hline Species & 1939 & 1940 & 1941 & 1942 & 1943 \\
\hline Bouteloua gracilis...... & 35.7 & 18.8 & 31.1 & 59.4 & 55.6 \\
Buchloe dactyloides.... & 12.2 & 8.1 & 13.6 & 12.4 & 19.5 \\
Andropogon furcatus... & .2 & $\ldots$. & $\ldots . .5$ & $\ldots . .7$ & $\ldots . .6$ \\
Bouteloua curtipendula . & 3.2 & .2 & .5 & 1.7 & 1.6 \\
Total........... & 51.3 & 27.1 & 45.2 & 73.5 & 76.7 \\
\hline
\end{tabular}

The great increase of blue grama from about 19 to nearly 56 per cent after 1940 is the outstanding change. The relict stand produced much seed and in this partly open cover seedlings grew in abundance. Buchloe dactyloides increased steadily but more slowly. Bouteloua curtipendula was poorly represented. The original cover of 1940 had increased nearly threefold, and in late drought consisted almost entirely of short grasses. The loss of bluestems was general in this ecotone; they are now slowly returning. 


\section{Percentage Change in Composition of} Basal Cover

In the preceding tables the actual amounts of basal cover before and during recovery in the several communities have been considered. The part played by each species (its loss or gain) from year to year is now presented as a percentage increment of the total cover (100 per cent) whether the actual basal area was large or small. In this way the part of the perennial cover that each species composed may be compared more directly. Thus, if a quadrat had only two species, blue grama with a basal cover of 10 per cent and buffalo grass with 10, then each species composed 50 per cent of the cover. Data from the several groups of quadrats are shown in Table 16.

In the short-grass type, buffalo grass and blue grama were about equally important in 1932, and together constituted 96 per cent of the vegetation. This nearly equal mixture probably occurred over much of the mixed prairie. The amount of short grass, however, varied in rather direct proportion to the degree of overgrazing, which was the fundamental cause of the great depletion of mid grasses (Clements 1936, Clements \& Chaney 1937). The more or less equal amounts of short grasses had been very general. This condition maintained at Hays, Kansas, in range land that had been fenced and only moderately grazed since 1900 (Albertson 1937). After 8 years of drought the more stable blue grama (in 1940) composed 59 per cent of the cover and the less xeric buffalo grass 35 . But the stoloniferous species recovered so rapidly that at the end of 1943 it composed two-thirds of the vegetation. Other species are of interest but of minor importance. Aristida disappeared during drought but returned in 1943. Sporobolus cryptandrus appeared during drought, occurred sparingly in 1940, and disappeared from the sod of buffalo grass. Both of these phenomena will be shown to be general throughout the region.

Behavior of the short grasses in the ecotone, where conditions of life were severe, shows that from an equal mixture of the species, blue grama increased its percentage while buffalo grass greatly decreased. Thus, in 1940 there was more than twice as much blue grama. Although there was a scattered stand of buffalo grass in 1941 ( 8 per cent basal cover), it decreased in this relatively shallow soil with high runoff until finally blue grama alone furnished 72 per cent of the vegetation. An original 5 per cent increment of side-oats grama never was restored; instead this grass decreased. None of the other 5 species found before the drought reappeared after its close.

Little bluestem alone composed 45 per cent of the basal cover in its type before the drought. This was reduced to 1 per cent in 1940 and never thereafter exceeded 4.1 per cent. Big bluestem was likewise reduced from a predrought stand of 17 per cent to a low of 0.4. Its cover in 1943 was very small, 3.5 per cent. In this habitat with taller grasses, blue grama increased from a predrought stand of 8 per cent to 31 in 1940, a poor period for the growth of any but the most xeric species. But with increase of taller grasses, especially side-oats grama, its stand was reduced to about one-third. Buffalo grass also suffered reverses after 1940 but tripled its 1941 area which was 3.2 per cent. Side-oats grama with a predrought stand of 17 per cent composed 42 per cent of the entire cover in 1940. This xeric mid grass spread rapidly and, although decreasing a little from its maximum amount (78.6 per cent in 1941), formed two-thirds of the cover in 1943. Other species were of relatively little importance, but it is of interest that with an increasing cover after 1940, sand dropseed lost all of its 7 per cent of the basal area.

TABle 16. Percentage composition of the various peremial grasses composing the basal cover in communities of mixed prairie before the drought (1932), at its close (1940), and during the years of recovery.

\begin{tabular}{|c|c|c|c|c|c|c|c|c|c|c|c|c|c|c|c|c|c|c|}
\hline \multirow[t]{2}{*}{ Species } & \multicolumn{5}{|c|}{ Short-Grass Type } & \multicolumn{5}{|c|}{ Ecotone } & \multicolumn{5}{|c|}{ Little Bluestem Type } & \multicolumn{3}{|c|}{$\begin{array}{c}\text { Big Bluestem } \\
\text { Type }\end{array}$} \\
\hline & 1932 & 1940 & 1941 & 1942 & 1943 & 1932 & 1940 & 1941 & 1942 & 1943 & 1932 & 1940 & 1941 & 1942 & 21943 & 1932 & 1940 & 1943 \\
\hline Bouteloua gracilis. . & 48.5 & 59.0 & 56.0 & 36.0 & 33.0 & 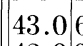 & 66.0 & 68.0 & 87.0 & 72.0 & 8.0 & 31.0 & 14.3 & 316.2 & 211.0 & 3.0 & 12.0 & 5.0 \\
\hline $\begin{array}{l}\text { Buchioe dactyloides... } \\
\text { Aristida purpurea and }\end{array}$ & $|47.5|:$ & 35.0 & 43.0 & 64.0 & 66.0 & 42.0 & 30.0 & 30.0 & 10.0 & 25.0 & 0.5 & 6.0 & 3.2 & \begin{tabular}{|l|l|}
2 & 5.6
\end{tabular} & 510.0 & 2.0 & 20.0 & 3.0 \\
\hline $\begin{array}{l}\text { Aristida purpurea and } \\
\text { A. longiseta. . ....... }\end{array}$ & 1.5 & & & & 1.0 & $\mid 1.0$ & & & & & 2.0 & 1.0 & & & & & & \\
\hline $\begin{array}{l}\text { Sporobolus cryptandrus.... } \\
\text { Sitanion hystrix.......... }\end{array}$ & & 3.5 & & & & & & & & & 7.0 & 7.0 & & & & & & \\
\hline Schedonnardus paniculatus & & 1.0 & & & & 1.0 & 0.5 & & & & & & & & 0.5 & & & \\
\hline Andropogon scoparius..... & 1.0 & & & & & 5.0 . & & & & & 45.0 & 1.0 & 1.0 & 4.1 & 3.0 & 1.0 & & \\
\hline Bouteloua curtipendula.... & $\ldots$ & & & & & 5.0 & 1.0 & 1.5 & 2.4 & 2.4 & 17.0 & 42.0 & 78.6 & 64.2 & 266.0 & $\mid 5.0$ & 15.0 & 3.0 \\
\hline Andropogon furcatus . . & & & & & & 1.5 & & & & & $\mid 17.0$ & 4.0 & 0.4 & $\begin{array}{l}4.1 \\
\mid 1.1\end{array}$ & $1 \mid 3.5$ & 76.0 & 15.0 & 70.0 \\
\hline Sporobolus pilosus... & . & & & . & & 0.1 & 1.0 & & & & 1.0 & 2.0 & 0.8 & 1.1 & $\mid 0.5$ & & & \\
\hline Bouteloua hirsuta... & & & & & & & & & & & 2.0 & 5.0 & 1.7 & 7.6 & $3 \mid 4$ & & & \\
\hline Panicun virgatum. & & & & & & $\ldots$ & & & $\ldots$ & & & $\ldots$ & $\ldots$ & $\ldots$ & $\ldots$ & 2.0 & 2.0 & 2.0 \\
\hline Agropyron smithii. . & & & & & & & & & & & & & & & & 4.0 & 20.0 & 5.0 \\
\hline Sorghastrum nutans & & & & & & & & & . & & & & $\ldots$. & & . . & 2.0 & & 1.0 \\
\hline Elymus virginicus...... & & & & & & & & & & & & & & & & 2.0 & 1.0 & 1.0 \\
\hline Sporobolus asper hookeri... & & & & & & & $\cdots$ & & $\cdots$ & & & & $\ldots$ & $\ldots$ & & 2.0 & 13.0 & 10.0 \\
\hline Total. & 99.0 & 98.5 & 99.0 & 100 & 100 & $\left.98.6\right|^{9}$ & 98.5 & 99.5 & 99.4 & 99.4 & 99.5 & 99.0 & 100 & 99.9 & 99.0 & 99.0 & 98.0 & 100 \\
\hline
\end{tabular}


The dense sod of big bluestem, although mostly dormant during the drought, easily regained its place as dominant with the return of more or less normal rainfall and run-in water. Thus, although the percentage composition ( 76 per cent) was reduced to 15 in 1940, it was again 70 per cent after three years of recovery. Western wheat grass, which had increased fivefold during the dry years, was again reduced to about its normal predrought proportion (5 per cent) of the cover. Sporobolus asper hookeri seemed to be losing its gains made during drought; Sorghastrum nutans had reappeared, and Elymus virginicus and Panicum virgatum maintained their small percentages of cover. Both species of grama increased to three or four times their predrought abundance. But like buffalo grass, which really attained a good hold (20 per cent) in 1940, their percentages of cover decreased rapidly in this tall-grass type when conditions for growth of the dominants again became favorable.

Summarizing Table 16, it may be seen that the new postdrought cover in both the short-grass type and ecotone was nearly all buffalo grass and blue grama. There was a 2 to 1 dominance of buffalo grass in the general short-grass type and a ratio of blue grama to buffalo grass of about 3 to 1 in the shallower soils of the ecotone. Little bluestem in its type not only yielded its dominance to side-oats grama and the short grasses but also suffered almost total extinction. Big bluestem in its type soon regained dominance which had been assumed by wheat grass, side-oats grama, sporobolus, and short grasses during drought. Nor were its rhizome-producing tall-grass associates destroyed.

\section{Studies in West Central Kansas}

Studies of the effects of the drought on the vegetation were expanded in 1937 by placing meter quadrats in representative areas at 15 different stations in west central Kansas (Fig. 1). Fach quadrat was recharted annually thereafter, and studies were made of the general conditions of the surrounding vegetation. The results are grouped according to the conditions to which the area had been subjected previous to 1937 (cf. Albertson \& Weaver 1942). The amount of subsequent dusting varied somewhat, but the classification is reasonably accurate. Condition 1 indicates light dusting and moderate grazing; 2, light dusting and overgrazing; 3 , heavy dusting and moderate grazing; and 4, heavy dusting and overgrazing (Table $17)$.

TABLE 17. Deviation from mean annual precipitation, condition, per cent of basal cover of blue grama and buffalo grass, and total basal cover in representative pastures near each station.

\begin{tabular}{|c|c|c|c|c|c|c|c|c|c|c|c|c|c|c|c|}
\hline Year & 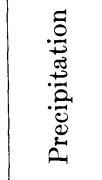 & 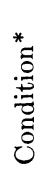 & 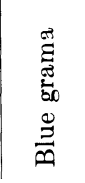 & 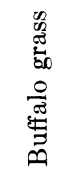 & 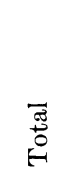 & 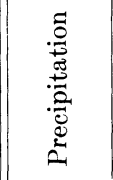 & 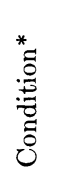 & 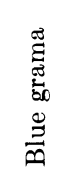 & 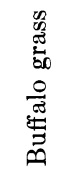 & 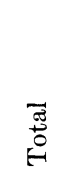 & 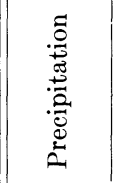 & 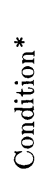 & 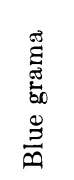 & 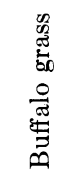 & 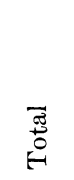 \\
\hline & \multicolumn{5}{|c|}{ Quinter } & \multicolumn{5}{|c|}{ Oakley } & \multicolumn{5}{|c|}{ Deerfield } \\
\hline 1940. & -0.7 & 1 & 1.7 & 3.5 & 5.2 & -2.2 & 2 & 3.9 & 1.0 & 4.9 & -0.6 & 3 & 0.7 & 0.1 & 0.8 \\
\hline 1941. & +8.9 & 1 & 22.0 & 42.7 & 64.7 & +15.8 & 2 & 17.4 & 3.1 & 20.5 & +7.3 & 3 & 0.8 & 1.7 & 2.5 \\
\hline 1942 . & +2.6 & 1 & 16.9 & 80.5 & 97.4 & +2.6 & 2 & 25.6 & 9.4 & 35. & +4.2 & 3 & 2.2 & 33.7 & 35.9 \\
\hline 1943. & +1.4 & 1 & 11.5 & 87.2 & 98.7 & -3.8 & 2 & 29.0 & 14.3 & 43.3 & -6.0 & 3 & 3.0 & 47.4 & 51.4 \\
\hline & \multicolumn{5}{|c|}{ Oakley } & \multirow{2}{*}{\multicolumn{5}{|c|}{ ats) }} & \multicolumn{5}{|c|}{ yracus } \\
\hline 1940 & -2.2 & 1 & 1.2 & 1.3 & 2.5 & & & & & & -4.1 & 3 & 0.0 & 0.0 & 0.0 \\
\hline 1941 . & +15.8 & 1 & 6.1 & 13.4 & 19.5 & +8.9 & 3 & 12.9 & 10.0 & 22.9 & +8.6 & 3 & 0.0 & 0.1 & 0.1 \\
\hline 1942. & +2.6 & 1 & 13.0 & 76.4 & 89.4 & +2.6 & 3 & 15.3 & 36.4 & 51.7 & +2.0 & 3 & 0.0 & & 0.5 \\
\hline 1943. & -3.8 & 1 & 14.8 & 82.3 & 97.1 & +1.4 & 3 & 24.7 & 38.0 & 62.7 & -8.5 & 3 & 0.0 & 1.2 & 1.2 \\
\hline & \multicolumn{5}{|c|}{ Scott City ${ }^{1}$} & \multicolumn{5}{|c|}{ Oakley ${ }^{1}$} & \multicolumn{5}{|c|}{ Tribune } \\
\hline 1940. & -3.0 & 1 & 0.0 & 0.4 & 0.4 & -2.2 & 3 & 0.0 & 1.5 & 1.5 & -0.7 & 4 & 5.4 & 0.0 & 5.4 \\
\hline 04 & +4.8 & 1 & 0. & 2. & 2.4 & +15.8 & 3 & 0.0 & 16.7 & & +7.9 & 4 & 12 & & 12.7 \\
\hline 1942. & +2.4 & 1 & 0.0 & 6.8 & 6.8 & +2.6 & 3 & 0.0 & 51.7 & 51. & +5.0 & 4 & 17.9 & 0 & 17.9 \\
\hline 1943. & -9.5 & 1 & 0.0 & 9.0 & 9.0 & -3.8 & 3 & 0.0 & 67.3 & 67.3 & -2.0 & 4 & 20.8 & 0.0 & 20.8 \\
\hline & \multicolumn{5}{|c|}{ Marienthal } & \multicolumn{5}{|c|}{$\begin{array}{c}\text { Ness City } \\
\text { (Av. } 4 \text { quadrats) }\end{array}$} & \multicolumn{5}{|c|}{ Holcomb } \\
\hline 1940 & -3.0 & 1 & 1.0 & 1.7 & 2.7 & +4.0 & 3 & 6.1 & 6.9 & 13.0 & +1.3 & 4 & 0.0 & 0.0 & 0.0 \\
\hline 194 & +6.4 & 1 & 2 . & 23.7 & 26.5 & +4.7 & 3 & 11.8 & 43.3 & & +6. & 4 & 3 & & 8.2 \\
\hline 1942 & +2.3 & 1 & 4.8 & 84.5 & 89.3 & +7.0 & 3 & 16.4 & 56.8 & 73.2 & +0.5 & 4 & 16.5 & 29.5 & 46.0 \\
\hline 1943. & -0.1 & 1 & 4.8 & 92.4 & 97.2 & & 3 & 20.8 & 75.6 & 96.4 & -5.8 & 4 & 15.7 & 41.8 & 57.5 \\
\hline & \multicolumn{5}{|c|}{ Quinter } & \multicolumn{5}{|c|}{$\begin{array}{c}\text { Dighton } \\
\text { (Av. } 2 \text { quadrats) }\end{array}$} & \multicolumn{5}{|c|}{ Syracuse } \\
\hline 1940. & -0.7 & 2 & 11.5 & 3.4 & 14.9 & -2.1 & 3 & 1.5 & 5.5 & 7.0 & -4.1 & 4 & 0.0 & 0.0 & 0.0 \\
\hline & +8.9 & 2 & 14. & 24.8 & & +8.0 & 3 & 6.9 & 36.5 & 43. & +8.6 & 4 & 0 . & & 0.3 \\
\hline 1942. & +2.6 & 2 & 17.4 & 41.0 & 58.4 & +5.3 & 3 & 11.8 & 64.2 & 76.0 & +2.0 & 4 & 0.3 & 0.0 & 0.3 \\
\hline 1943. & +1.4 & 2 & 18.9 & 75.0 & 93.9 & -6.6 & 3 & 10.4 & 83.3 & 93.7 & -8.5 & 4 & 0.0 & 0.0 & 0.0 \\
\hline
\end{tabular}

${ }^{1}$ These quadrats had a fairly large cover of Sporobolus cryptandrus not shown in this table.

*Condition at time quadrats were laid out in 1937: 1, lightly dusted, moderately grazed; 2, lightly dusted, overgrazed; 3 , heavily dusted, moderately grazed; 4 , heavily dusted, overgrazed. 
The basal cover in 1940 varied from 0.4 to 5.2 per cent under condition 1 , and averaged only 2.7 per cent. With one exception, the cover varied from 19.5 to 64.7 per cent the next year and averaged 36.9 per cent. At Scott City a sixfold gain of buffalo grass resulted in only 2.4 per cent cover. This increased so slowly, despite precipitation above normal, that in 1943 it was only 9 per cent. But great gains occurred at all the other stations. Thus, in 1942, with precipitation above normal, the cover ranged between 89 and 97 per cent. A further increase at all three stations to 97-99 per cent occurred in 1943. This rapid recovery of the ranges was due largely to buffalo grass. The ratio of blue grama to buffalo grass after drought was about 2 to 3 . But in 1943 it was 1 to 8.4.

Under light dusting and overgrazing (condition 2), an average of 9.9 per cent cover occurred in 1940 . It increased to 30.1 under precipitation far above normal. At Oakley, where blue grama was most abundant, the cover in 1943 was 43.3 per cent, but at Quinter buffalo grass occurred in greater amounts during the second year, and the final cover was 93.9 per cent.

Where the area was heavily dusted and moderately grazed (condition 3), the average percentage of basal cover was 5.5 in 1940. One station (Syracuse) is omitted since there was no cover in 1940 , only a trace in 1941-42, and but 1.2 per cent in 1943, despite good rainfall. Cover at the other stations varied greatly in 1941 (2.5 to 65.1 ) but was nearly always fair. It averaged 30.1 per cent. With this fine start, recovery was rapid with continued precipitation of 2.6 to 7 inches above normal. Thus, the average in 1942 was 57.7 per cent. This increased the next year to 74.3 . The lowest cover in 1943 (51.4) occurred at Deerfield, the highest (96.4) at Ness City where blue grama furnished only 20.8 per cent. There was no blue grama at Oakley, and buffalo grass greatly exceeded blue grama at all the remaining stations.

Vegetation under condition 4, where the grass was heavily dusted and overgrazed, not only suffered greatest from the drought but also recovered least rapidly. There was no cover at two stations in 1940 and only 5.4 per cent at Tribune. Despite unusually high precipitation at Syracuse in 1941-42, the soil was still free of short grasses in 1943. At Tribune where blue grama only was present it increased gradually from 5.4 to 20.8 per cent cover. But at Holcomb both short grasses entered the area in 1941 and increased year by year, buffalo grass much faster than blue grama, until a cover of 57.5 per cent was attained in 1943.

Summarizing, the average initial cover (1940) under the four conditions was $2.7,9.9,5.5$, and 1.8 per cent, respectively, and the final cover $75.5,68.6$, 62.1 , and 26.1 per cent. Thus, recovery was most rapid in lightly dusted and moderately grazed ranges and slowest of all where overgrazing had been practiced and dusting was heavy.

\section{THE SUBSERE}

Recovery from drought over the vast area of range land was not a simple or single phenomenon. It was quite different on the level or moderately undulating uplands, where the short-grass type prevailed, from that on more restricted rolling and rougher areas where postclimax bluestems and other grasses dominated. Although these were given considerable attention, the most extensive study of the subsere was made in the short-grass type, and this section is concerned with it alone.

\section{Conditions for Succession}

There were great differences in the degree of denudation by drought in the different areas. In some places not only was the vegetation entirely destroyed but the rich topsoil in which it was rooted was swept away. Here succession on the hard soil was indeed slow. Where the vegetation was well intact but destroyed by a deep covering of dust, the early weed stages also prevailed for a long time. These were the usual conditions in much of the dust bowl but they also occurred in widely scattered places elsewhere. Sometimes drifts of dust were still covered with weeds in 1943, where the dust had been deposited in a single year. Small drifts which were originally only an inch or two in height often became clothed with grass. But with the gradual accumulation of more soil they were built into heaps and ridges 8 to 12 inches high. They have gradually become wider and longer and are now often 3 to 8 feet in width. Sometimes portions of a single pasture exhibited both of these extremes, while the remainder, which was only partially depleted of its vegetation, had regained a good cover.

The general trends of destruction may be summarized for the whole area. In those where drought was severe, species with the poorest root systems or highest water requirements vanished first. Some of the more drought resistant usually remained in patches or as scattered bunches or individuals, but all decreased rapidly in density, size, and seed production. Recovery was slow where only widely scattered remnants remained. It was usually much more rapid where one-third or more of the cover was left intact (Figs. 82 and 83). Moreover, not only previous treatment of the range as regards grazing but also the conditions during the 8 years of drought greatly influenced the rate of final recovery after 1941 (Fig. 84). Chief among these were amount and distribution of precipitation, time and intensity of grazing, and further dusting (Fig. 85). Even when good years came, a period of time seemed necessary on some dusted ranges for the grasses to recover from deep dormancy (Albertson \& Weaver 1944). Before succession had proceeded far in the southwestern area, midsummer drought occurred again in 1943. In some ranges all green plants dried in August and grasshoppers fed on the tender sweet portions of the almost dormant stolons of buffalo grass. Thus, this area still exhibits the earlier and medial stages leading back to a complete cover of perennial grasses. Later stages, and usually a short-grass disclimax stage, have been reached over the northern and eastern portion of this mixed prairie area. 


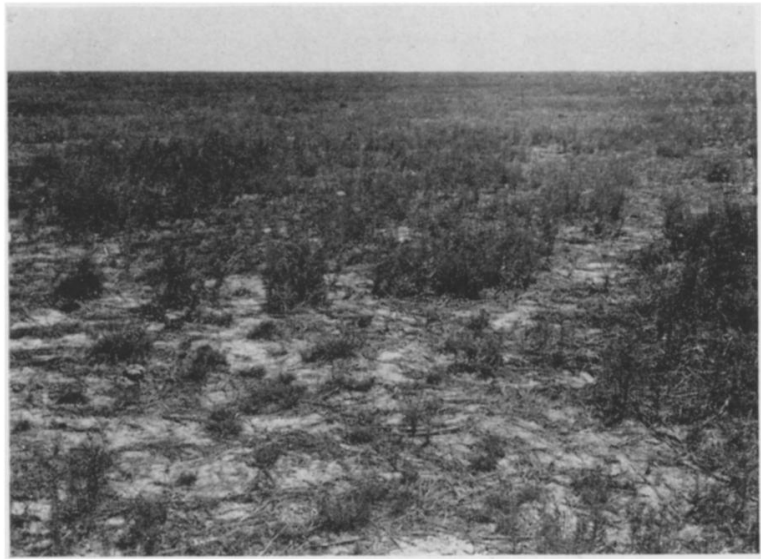

Fig. 82. Range south of Sheridan Lake, Colo., in August, 1943. There are a few old plants of blue grama (center) and some seedlings in the foreground. The dense weeds in the background are Leptilon canadense.

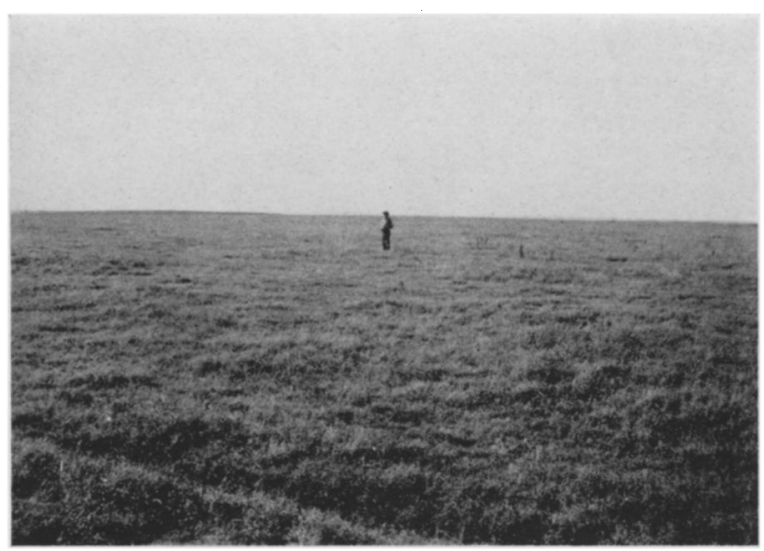

Fig. 83. General view of large range near Ogallah, Kan., showing an excellent cover of short grasses where practically all weeds have disappeared. August, 1943.

Where a moderate amount of precipitation was well distributed (1940-43) growth was more or less continuous throughout the season and the subsere was shortened. For example, at Hays, Kansas, where destruction of the ranges was only partial, precipitation was high for mixed prairie from 1940 to 1942 , inclusive. Because of the severe drought of 1939, vegetation was at its lowest ebb in the spring of 1940. The cover was greatly reduced everywhere and large areas had only scattered perennial grasses, and many others were practically bare. But by fall the cover had increased to 2-20 per cent. By the autumn of 1941 the basal area varied usually between 40 and 60 per cent, and by the end of 1942 there was 70 to 90 per cent cover. Thus, in a period of three years the earlier stages in the subsere had been replaced by the short grasses. It should be recalled, however, that the earlier weed stages had persisted since the death of most of the perennial vegetation in 1933-34, that is for a period of 8 years.

Under less favorable normal climatic conditions

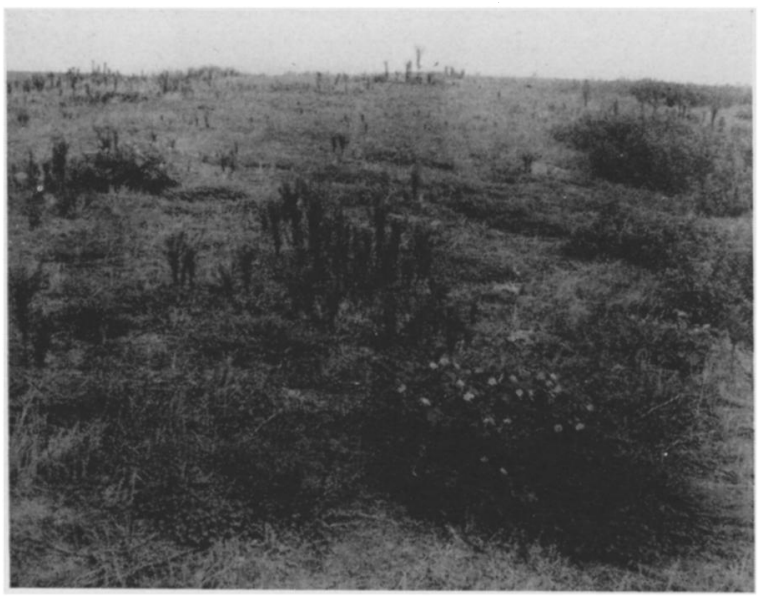

FIG. 84. Range kept in early weed stage by overgrazing, 1943. This is the flat top of a large loess hill 14 miles southeast of Broken Bow, Neb. Grazed horseweed occurs in the center, buffalo bur in blossom, with prostrate spurges near it and also in the background, and western ragweed on the right. No perennial grasses grew in the area shown in the picture.

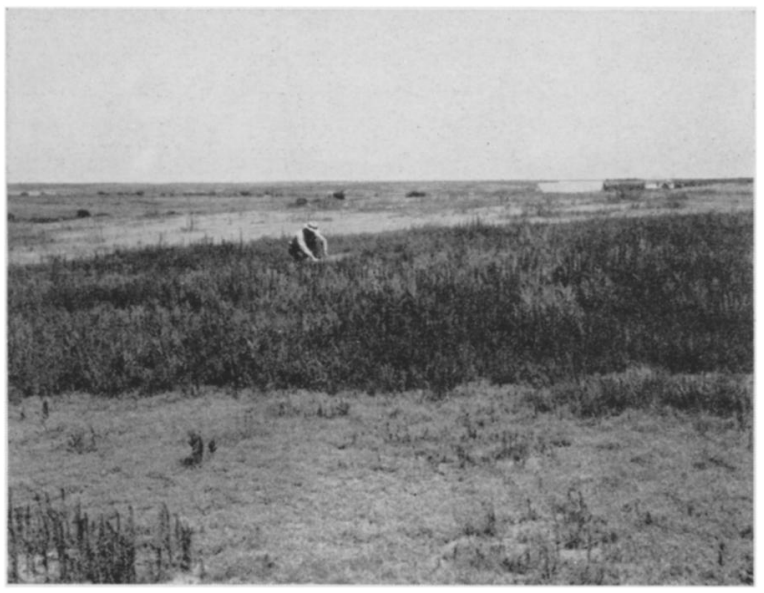

Fig. 85. Alterne of horseweed and lamb's quarters (16 inches tall) about 25 paces wide, in dust-covered short-grass pasture near Ravenna, Neb. The short grasses were all killed by the dust and drought, but a new sod has been developed from relicts outside the alterne which were less deeply covered with dust.

southward and westward the drought had been much more severe and vast areas were so denuded by desiccation and erosion or deposit of soil that they were either almost or entirely bare. When rains came in 1940 to the eastern margin of the dust bowl, as they did at Hays, the long dry period continued westward, although with less severity. Hence these terribly denuded ranges remained in some early stage of succession (depending upon local conditions) even to the end of 1943. For here not only had an environment mostly unfavorable for growth been maintained but also perennial grasses were absent or so sparse that they produced almost no seed and spread but little by vegetative propagation. Throughout this territory 
buffalo grass had been rather widely exterminated and its return was nearly always by seed and not by extension of stolons, an extremely rapid method of propagation.

A rather general cause of the delay in reestablishment of perennial grasses not only during the most favorable years of drought but even during the first year of good rainfall was a dearth of seed. In 1941 samples of soil were collected at random from 40 different ranges in mixed prairie, nearly all in western Kansas and eastern Colorado (Weaver \& Mueller 1942). Three to five samples 0.5 inch deep and one square foot in area were taken at random from each range in very early spring. All viable seed in these soils was germinated under very favorable conditions in a greenhouse. More than 11,000 seedlings emerged from the 151 samples of soil. Of these about 6,000 were grasses, including many weedy annuals. Approximately 75 per cent of the grass seedlings were blue grama, buffalo grass, and sand dropseed. Blue grama was represented in 52 per cent of the samples and occurred at an average rate of 3.7 seedlings per square foot. Buffalo grass was found in only 12 per cent and at the low rate of 0.5 per square foot. There was no side-oats grama or little bluestem, and few other grasses except sand dropseed. It was found in 63 per cent of the samples and at the average rate of 26 seedlings per square foot.

In field studies in 14 of the more northerly of these mixed prairie stations, 25 square-foot samples were examined minutely in June of this very favorable year for germination and seedling growth. Average distribution of perennial grass seedlings in these ranges was only 2.4 per square foot. Repeated search for seedling grasses in the more northerly of the western Kansas stations in June and early July revealed only a few at certain stations. Elsewhere they were rare to none, since many of the ranges had been almost depopulated, and continued drought had prevented even the relicts from producing viable seed.

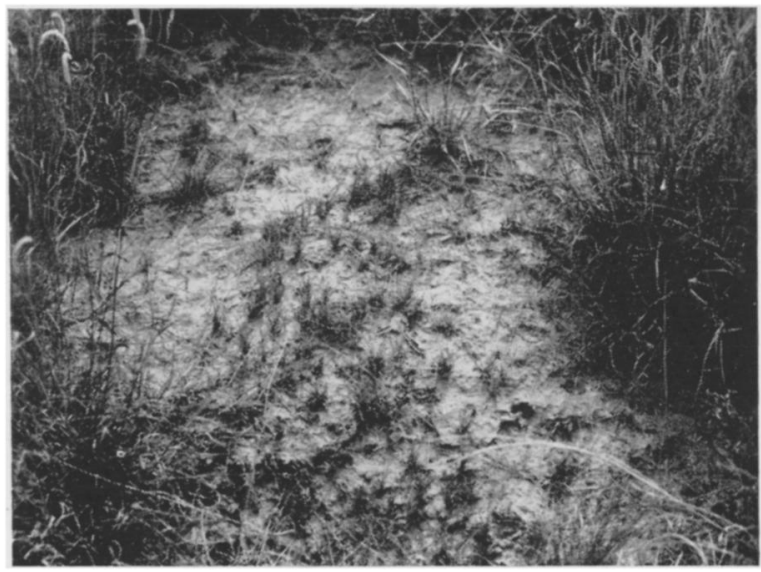

Fig. 86. Reproduction in bare open spaces between bunches of blue grama. The seedlings are one- and twoyear-old tumblegrass (Schedonnardus), wire grass (Aristida), and blue grama (Bouteloua).
Over most of the mixed prairie there had been enough rainfall to moisten the soil continuously for several days, a condition necessary for seed germination. But, with rare exceptions, the seedlings died from lack of a sufficient water supply. Hence recovery by seedlings awaited a second year of good rainfall (1942) for the newly produced seed crop to germinate. Then both germination of seed and successful establishment of seedlings occurred in very great numbers (Fig. 86). But meanwhile buffalo grass had been making great gains by stolons.

\section{Stages of Succession}

The stages of succession and the chief species composing each are as follows:

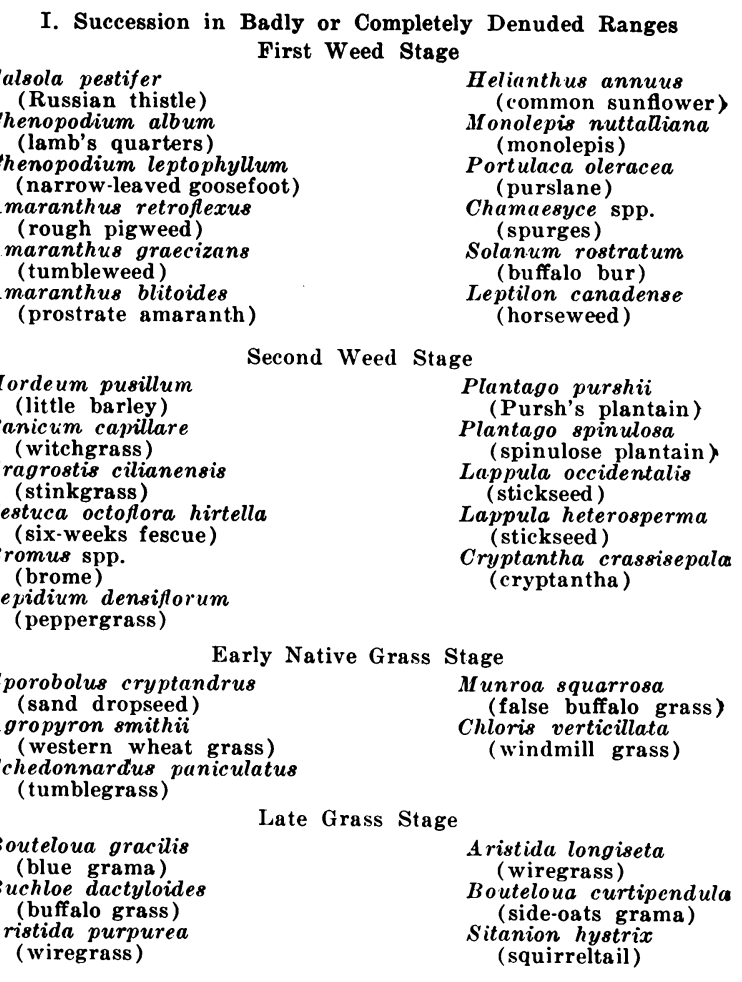

II. Succession in Ranges Reduced to One-Fourth or More of Normal Cover but with Sufficient Perennial Grasses to Regenerate Quickly

\begin{tabular}{|c|c|}
\hline \multicolumn{2}{|l|}{ Weed stage } \\
\hline $\begin{array}{l}\text { Hordeum pusillum } \\
\text { (little barley) } \\
\text { Festuca octoflora hirtella } \\
\text { (six-weeks fescue) } \\
\text { Bromus spp. } \\
\text { (brome) } \\
\text { Lepidium densiflorum } \\
\text { (peppergrass) } \\
\text { Plantago purshii } \\
\text { (Pursh's plantain) } \\
\text { Plantago 8pinulosa } \\
\text { (spinulose plantain) }\end{array}$ & $\begin{array}{l}\text { Lappula occidentalis } \\
\text { (stickseed) } \\
\text { Lappula heterosperma } \\
\text { (stickseed) } \\
\text { Cryptantha crassisepala } \\
\quad \text { (cryptantha) } \\
\text { Diaperia prolifera } \\
\text { (diaperia) } \\
\text { Leptilon canadense } \\
\text { (horseweed) } \\
\text { Salsola pestifer } \\
\quad \text { (Russian thistle) }\end{array}$ \\
\hline $\begin{array}{l}\text { Early Native Grass } \\
\text { Sxorobolus cryptandrus } \\
\text { (sand dropseed) } \\
\text { Agropyron smithii } \\
\text { (western wheat grass) } \\
\text { Schedonnardus paniculatus } \\
\quad \text { (tumblegrass) } \\
\text { Aristida purpurea } \\
\text { (wiregrass) }\end{array}$ & $\begin{array}{l}\text { Stage } \\
\text { Aristida longiseta } \\
\text { (wiregrass) } \\
\text { Sitanion hystrix } \\
\text { (squirreltail) } \\
\text { Munroa squarrosa } \\
\text { (false buffalo grass) }\end{array}$ \\
\hline $\begin{array}{l}\text { Late Grass Sta } \\
\text { (Same as in preceding }\end{array}$ & absere) \\
\hline
\end{tabular}


EXAMPLES OF SERAL STAGES

The stages in succession were not represented uniformly over any considerable territory nor were all parts of any one large range usually in the same stage of development during a particular year, unless denudation had been general and complete. Usually there was a patchwork of patterns representing different stages in recovery toward the climax. The concept of the presence of the various stages and of their overlapping in time and space may best be gained from a presentation of various actual examples (cf. Shantz 1917, Savage \& Runyon 1937, Judd \& Jackson 1939, and Tolstead 1941).

\section{Early Weed Stage}

A large range near Lakin, Kansas, had been heavily dusted in 1935 and at various periods thereafter. The native vegetation had been completely destroyed during the drought years. In the fall of 1942 only occasional bunches of buffalo grass and blue grama were found, but in no instance had they made much growth in recent years. Weeds were plentiful, especially annual sunflower, which was so abundant that one walked through the pasture with great difficulty in searching for the permanent quadrats located there.

In a large pasture one mile north of Syracuse, Kansas, the soil was practically bare in the spring of 1940. In the fall of 1940 there was no short grass but myriads of seedlings of sand dropseed. Two years later bunches of sand dropseed 2 to 4 inches in diameter but 4 to 24 inches apart formed a cover over much of the pasture and scattered plants of buffalo grass 3 to 8 feet apart occurred as an understory. The total perennial cover did not exceed 5 per cent. Russian thistle, horseweed, sunflower, and rough pigweed were very abundant. Common weeds of smaller stature were cryptantha, purslane, plantain, witchgrass, and spurge.

On a 360 -acre range 14 miles southeast of Broken Bow, Nebraska, long and severe grazing by both cattle and horses had prevented recovery of the vegetation from drought. In August, 1943, the vegetation was thinned to widely spaced relict mats of buffalo grass and blue grama which covered about 5 per cent of the soil but were grazed to within one-fourth inch of the ground. Even under a thick stand of western ragweed, which is uneaten and usually furnished adequate protection for short grasses, they were grazed closely. Mere traces of other pasture grasses and forbs remained. The weedy grasses, mostly annuals, occurred widely-little barley, witchgrass, false buffalo grass, and tumblegrass. Other weeds were abundant; most of them were closely grazed. Chief among these were spinulose plantain, annual sunflower, western ragweed, buffalo bur, seedling cactus, horseweed, and various prostrate spurges (Fig. 84). This was largely a man-made subsere. It resulted from overgrazing during and after the drought. Left unhindered, damage to the cover would have been repaired as it had been in nearly all of the adjacent ranges.

The processes of recovery on bared slopes and ridges were proceeding actively in many places in a range on rolling upland near Ravenna, Nebraska. Postdrought seedlings of blue grama, one to three years old, were abundant and had usually developed into bunches, mostly 1 to 3 inches in diameter. Small mats of buffalo grass, somewhat recently grown from seed, were plentiful and larger ones from drought survivors were 10 to 14 inches in diameter. Stolons had been extended widely. They threaded between the large surviving and often elevated bunches of blue grama, as well as its younger offspring. This presaged a dense sod. Alternating with these shortgrass strongholds the early stage of the subsere was well represented by Russian thistle, stinkgrass, lamb's quarters, buffalo bur, horseweed, and other annuals. But these were absent where a good sod had been formed.

Near Greeley, Nebraska, an entire valley oneeighth mile long was occupied by prairie dogs. The general area of occupation was marked, in August, 1943, by a good growth of tumblegrass (Fig. 87).

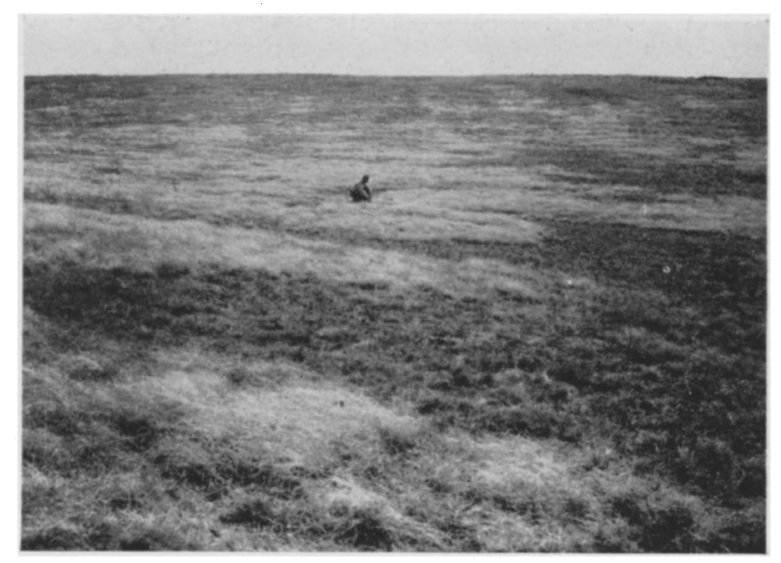

Fig. 87. Tumblegrass (Schedonnardus paniculatus) in a pasture infested with prairie dogs. Beyond the range of their grazing the vegetation is mostly blue grama or side-oats grama. Greeley, Neb., August, 1943.

The dried panicles occurred in great quantities, but when removed they revealed a thin stand of this grass on otherwise nearly bare ground (Fig. 88). All of the original perennial grasses-big and little bluestem, side-oats grama, blue grama, and buffalo grass-had been grazed so closely and so frequently that they had died. Around the mounds was an early subsere of mat-forming Chamaesyce, Amaranthus blitoides, Verbena bracteosa, Salsola pestifer, Boebera papposa, Aristida oligantha, and Leptilon divaricatum. The prairie dogs grazed Schedonnardus, Aristida, and most of the weeds as well as the original cover of blue grama and other perennial grasses. These perennials at first occurred sparingly and in isolated bunches on the adjoining slopes, but soon the vegetation beyond the area grazed by prairie dogs thickened until an excellent stand with basal cover of 40 to 80 per cent occurred. Here livestock were grazing the vegetation moderately. 


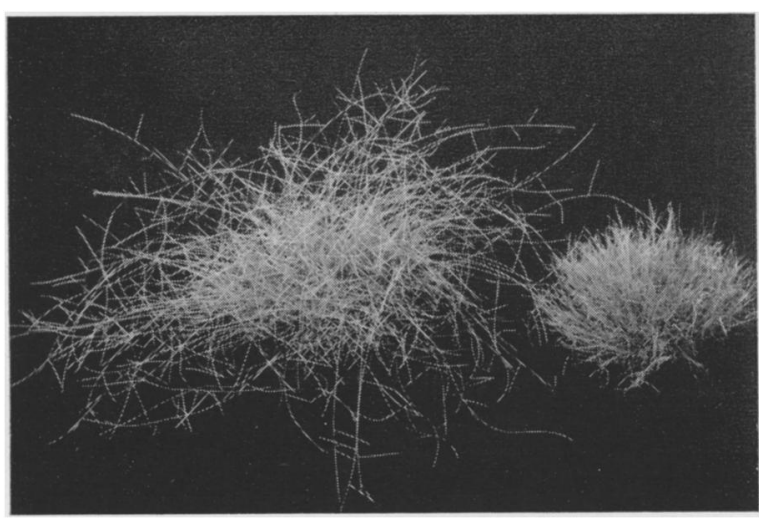

FIG. 88. Detail of a bunch of tumblegrass with panicles of moderate size (left), and another bunch, 5 inches tall, with panicles removed.

A 360-acre range 20 miles north of Limon, Colorado, was first examined in August, 1939. It had been heavily dusted, and all but 1 per cent of the original cover had been destroyed. Most of the dust had been removed by the wind after the vegetation died and thus failed to continue to hold it in place. Only widely spaced remnants of blue grama and buffalo grass remained in 1939 (Fig. 89). Most of the buffalo grass mats were small, only a foot or two in diameter. There was a very light sprinkling of sand dropseed and wheat grass, especially about the relict bunches of cactus. Traces of mountain sage (Artemisia frigida) also occurred. The population of annual weeds-plantain, peppergrass, and stickseed-had died and with the fragments of small Russian thistles had been drifted together. Many square yards were entirely without a living plant.

By August, 1942, the 1 per cent basal cover had

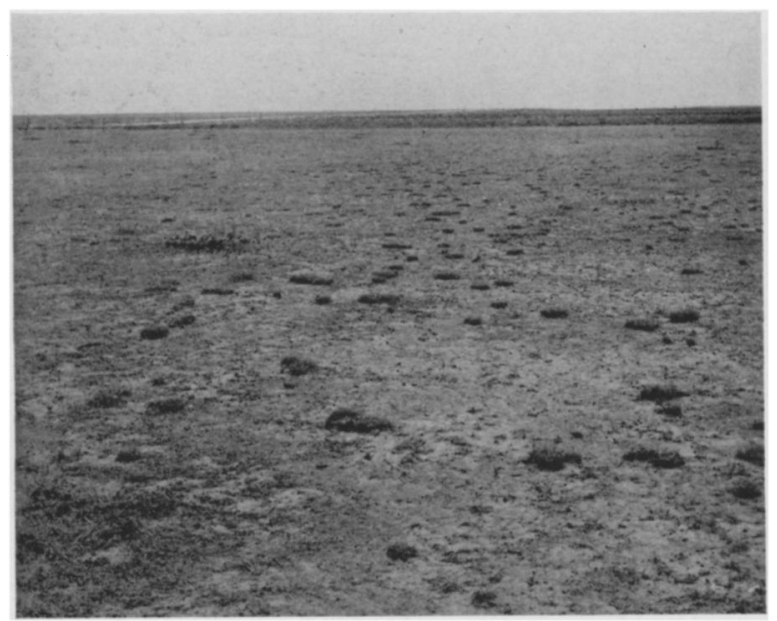

Fig. 89. Portion of a large, level, dust-covered pasture near Limon, Colo. The cover (bunches) of blue grama and buffalo grass has been decreased to less than 1 per cent. Only a few of the most drought resisting perennial forbs survived. Many annuals had made a precarious growth, succumbed to drought, and given the landscape its gray, barren aspect. August, 1939. increased to 11 . The bunches of blue grama had enlarged and many new ones had been established. Buffalo grass occurred in scattered streaks and patches, sometimes 5 feet in width, more or less throughout. These two grasses composed 6 per cent of the cover. The remainder was nearly all western wheat grass, but there were seattered plants of Sitanion hystrix, Schedonnardus paniculatus, and Sporobolus cryptandrus. Chief weeds were Artemisia frigida with its many seedlings, and Grindelia squarrosa. There were no Russian thistles, but dense stands of Festuca octoflora hirtella and Plantago purshii covered the otherwise bare, cracked, dustcovered soil. This was an excellent example of many ranges in early recovery from drought. This range was being grazed.

In July, 1943, the older bunches of blue grama had increased greatly in size; some were 9 by 16 inches in basal diameter. Many new areas had been successfully reseeded by this species and by buffalo grass. Patches of buffalo grass ranged from 1 to 12 feet in width and some elongated ones extended continuously for 15 feet. Remnants in an old road had resodded much of it. Wind erosion had often left bunches and small sodded areas of buffalo grass elevated an inch or more. Wheat grass occupied relatively large patches. It was often the dominant in low, flat ground, but in places it and the short grasses had developed a few square yards of typical mixed prairie (Fig. 90). Sitanion hystrix was fourth in abundance; there was also some Sporobolus cryptandrus, Muhlenbergia torreyi, and Schedonnardus paniculatus. In addition there were abundant seedlings of nearly all species. Total basal cover was about 15 per cent. Much of the soil not occupied by perennials was elothed with dense stands of Festuca octoflora hirtella, Plantago spinulosa, and numerous other weeds. The sage had increased greatly in

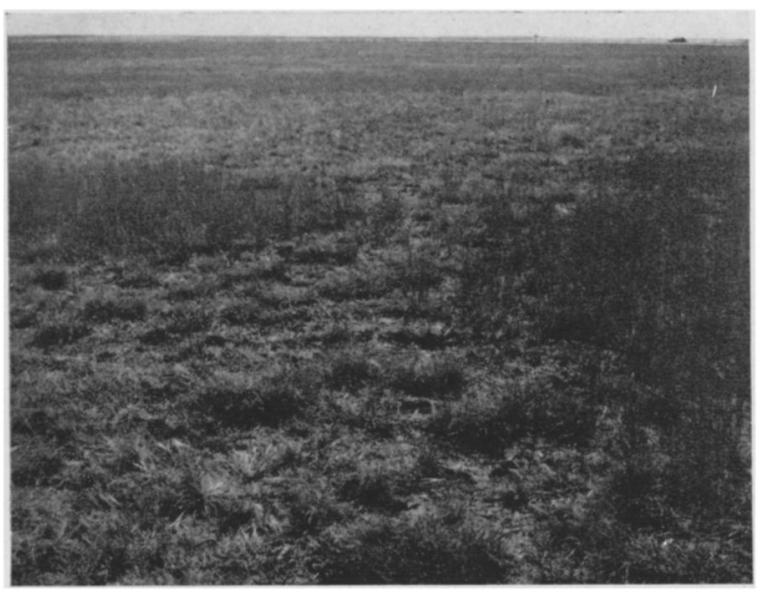

Fig. 90. General view (July, 1943) in the same range and nearly the same place as shown in Figure 89. The cover of perennial grasses had increased to about 15 per cent. Most of this was western wheat grass, dark patches in the forgeround and extensive area in the background. Foreground shows plants of blue grama beaten down by hail. 
abundance. This was one of the poorest ranges; although no recent dusting had occurred, its recovery had been delayed by close grazing.

\section{Medial Stage}

In August, 1942, a range at Ruleton, Kansas, on which the vegetation had been nearly destroyed by drought and light dusting possessed a basal cover of perennial grasses of 20 to 30 per cent. About 50 per cent was sand dropseed, 35 buffalo grass, and 15 blue grama (Fig. 91). No other perennial grasses were present. Many bared spaces were occupied by sand dropseed only. Abundance of Russian thistle and annual sunflower was an indicator of much open ground. False buffalo grass occurred sparingly. Seedlings of this and sand dropseed were abundant.

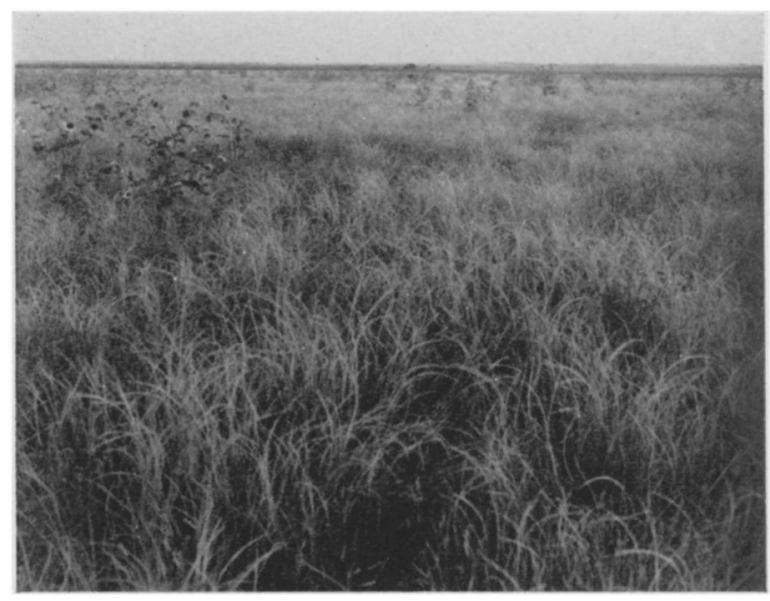

FIG. 91. A range at Ruleton, Kan., which had been badly denuded by drought and dust. An open stand of sand dropseed had developed with small patches of buffalo grass and blue grama (hidden in this view by the mid grass). Sunflowers and other weeds indicate bare soil. August, 1942.

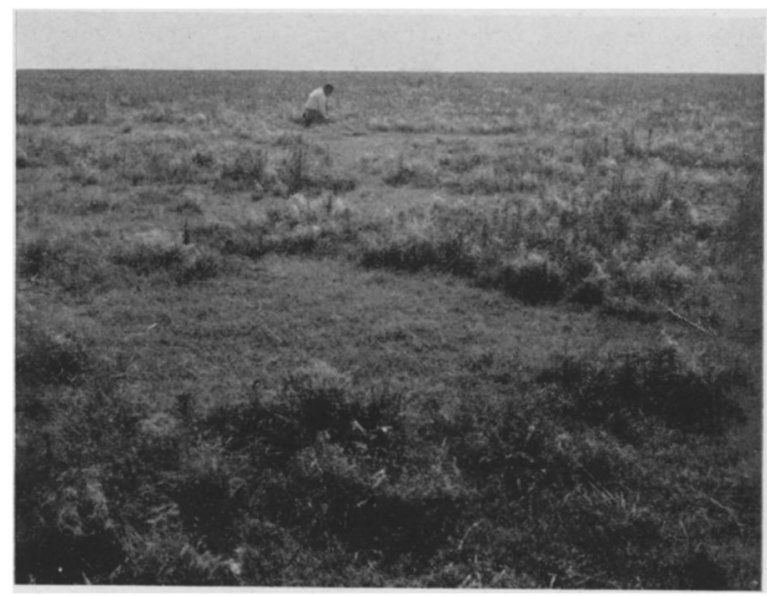

Fic. 92. The same range as in Figure 91 on July 19 , 1943, showing a great increase in the patches of buffalo grass, the less vigorous growth of sand dropseed, and scarcity of weeds. Basal area of the vegetation is twice that of the preceding year.
By July, 1943, the basal cover had doubled in amount and was now 50 per cent, of which half was buffalo grass (Fig. 92). Blue grama had increased but slowly from tillers and seedlings and composed 25 per cent, but sand dropseed now represented only 25 per cent of the perennial grasses, a loss of onehalf. There were no Russian thistles; horseweed was the chief ruderal, but a few sunflowers and lamb's quarters were also present. The open spaces were more or less filled with seedlings of sand dropseed, blue grama, and tumblegrass of various ages and also false buffalo grass. Little barley and six-weeks fescue were scattered thinly among the short grasses.

A later stage in succession occurred on the rolling hillsides near Beardsley, Kansas, in 1942, where level land gave way to characteristic "breaks" in country dissected by streams. Many thousands of acres of such land are under grazing and will remain thus since this is not arable land. On the steep slopes runoff and erosion had become great during drought, but were less on the moderately sloping hillsides. Much of the soil was covered with an open stand of blue grama, but there was also much bare soil. Erosion had removed the top soil in places and left bunches of blue grama elevated 2 inches above the present soil level (Fig. 93). The many tufts of blue

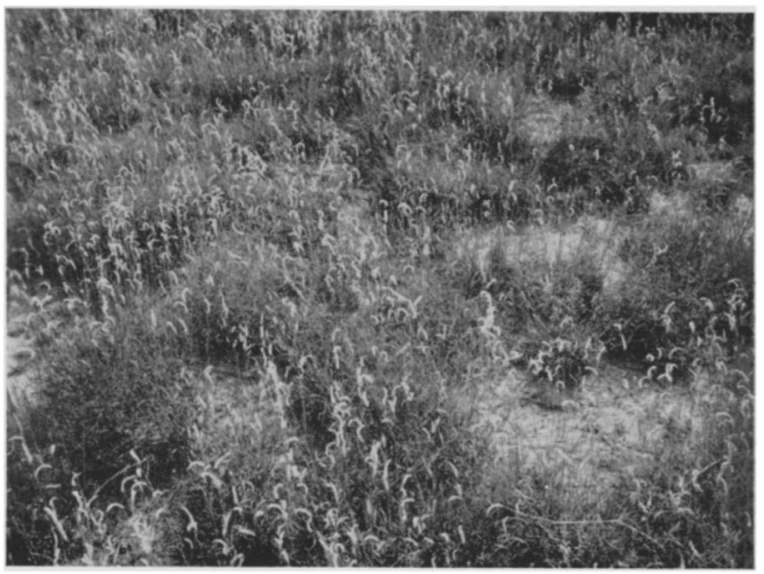

Fig. 93. Bunches of blue grama in flower on a steep hillside near Beardsley, Kan., in July, 1942. Many are elevated 1 to 3 inches as a result of soil erosion.

grama testified to a rapid recovery. Relict bunches and small patches of buffalo grass grew in the most favored places. They were not yet densely consolidated but were extending runners everywhere. Seedlings and young bunches of both wiregrass and tumblegrass were common. On the steepest and most abrupt slopes, locally designated as catsteps, widely spaced bunches of side-oats grama occurred plentifully. Sand dropseed was elsewhere. The hills had not been dust covered, but had lost much soil by wind erosion. The soil between the bunches of grasses was hard and mostly bare, since the usual soil mulch was not present. The weed stage was poorly represented by scattered plants of Russian thistle and witchgrass. Opuntia humifusa was common. The 


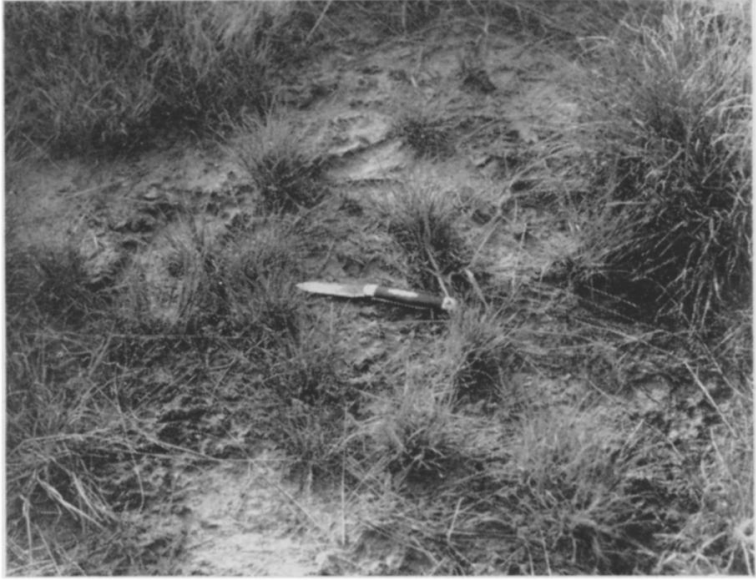

Fig. 94. Seedlings of blue grama in bare, eroded soil in an open cover of short grass such as occurs on steep slopes as shown in Figure 93. The young plants are mostly 2 to 3 years old.

abundance of seedling grass of nearly all the established species was impressive (Fig. 94). The range as a whole was well on the way toward recovery. The basal cover increased to 25 per cent where the slopes were less steep. Succession had proceeded more slowly than on adjacent level ranges, partly because of the smaller amount of buffalo grass. But this grass soon increased to 40 per cent of the entire cover; blue grama composed most of the remainder.

\section{Early, Medial, and Climax Stages}

A large pasture 8 miles northwest of Norton, Kansas, had been severely damaged by heavy dusting. In 1942 the dust was distributed thinly on the ridges and upper slopes but thickly on the brows of the hills and wind-protected lower ones. Often ridges and mounds of dust, still 2 to 2.5 feet high, remained. In this dynamic area there were many types of vegetation represented, and almost all degrees of mixtures. The density of annual sunflower indicated the degree of disturbance; the thicker the sunflowers the less relict vegetation occurred and the degree of recovery was least (Fig. 95).

Patches of sunflowers had little beneath them except ruderals, chief of which were witchgrass and horseweed. There were also relict bunches of blue grama or, less often, buffalo grass, as well as scattered patches of western ragweed. Elsewhere, species of Lactuca prevailed, often with remnants of short grasses beneath or intermixed with sand dropseed. Where dusting was just sufficient to kill the short grasses, sand dropseed occurred in open stands. In other places under similar conditions wheat grass formed extensive alternes. Areas occupied by these grasses varied in size from small patches to those several square rods in extent.

On the least dusted portions, the cover of short grasses remained. But it was greatly depleted by drought and had lost most of the buffalo grass. The stand was very open; usually only 15 to 20 per cent

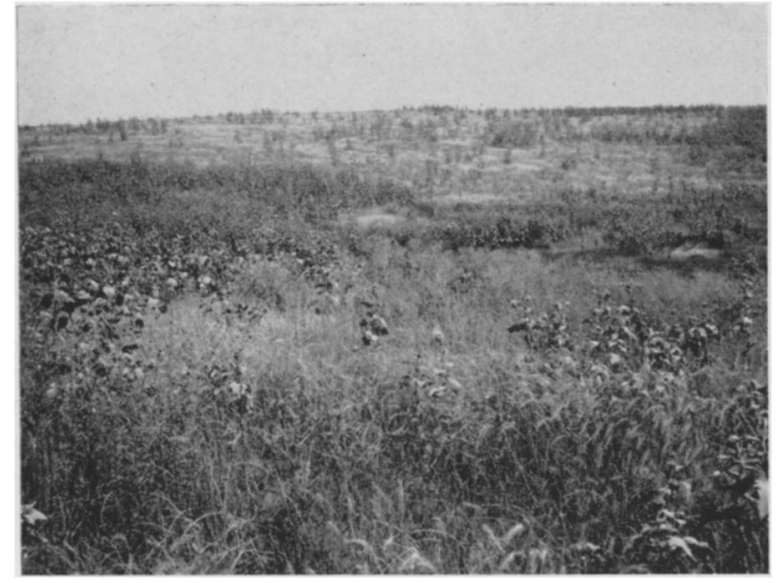

Fig. 95. General view of badly dusted range northwest of Norton, Kan., in July, 1942. The whole area was a mixture of weeds with patches of relict native grass.

of the soil was covered. Seedlings of blue grama were plentiful and the stolons of buffalo grass were spreading rapidly. The moist period had been too brief for much recovery, especially with so great a decrease in buffalo grass. The scattered but consolidated patches of this grass and wheat grass were the only ones free from an overstory of ruderals, except the slightly dusted areas on the most wind-swept slopes. The type of dusting indicated a good cover of vegetation at the time of dust deposit.

Blue grama had not had time to migrate far into the wheat grass patches or alternes of sand dropseed. The mixing that did occur was due to widely spaced relict bunches left in the invaded areas. Bunches or patches of blue grama were scattered almost throughout except where the soil was covered deeply with dust. Large bunches of dead, bleached cactus occurred.

Intermixing and overlapping of the communities was pronounced, and a wilderness of weeds almost obscured most of the scattered native grasses. Only the most stable vegetation was nearly free of annuals. In this patchwork one could find on the lower slopes a few islands of big bluestem, with flower stalks 5 to 6 feet tall. Little bluestem was also encountered; wild rye was scattered thinly in places, and enormous bunches of widely spaced side-oats grama grew on the upper slopes, and smaller ones were often intermixed with wheat grass. In fact, in this patchwork of fragmented communities almost all combinations of the above species were found. The wide, shallow ravines were thickly covered with a pure, dense stand of wheat grass. Although the soil was free of debris, it was mellow; seedlings of many species were abundant, and a large crop of seed was being produced. The vegetation had been plentifully supplied with water and was rank everywhere. Replacement of the ruderals by later stages of the subsere had begun.

This pasture was studied again in July, 1943. It had not been disturbed; the dried stems of the 
previous year were still intact. A good stand of sand dropseed had temporary control of the entire lower portion; the remnants of bluestems and nodding wild rye had been reduced so much that only a few bunches remained. Excellent bunches of blue grama and many patches of buffalo grass occurred all through the area of the old and new growth. The debris of dead weeds indicated that the next stage in the subsere had begun, and the presence of the short grasses portended the climax. Green weeds were few and dwarfed, especially where buffalo grass had formed a sod. This grass had spread 1.5 to 2 feet this year on the periphery of its numerous patches. Seedlings of both the mid grass and short grasses were common and two-year-old plants were present as well. This contrasted sharply with the very open cover of grasses in 1942 (Fig. 96). Wheat grass had succeeded in its early growth and thus kept its territory nearly free of weeds. Some less stable areas were partly occupied by very large bunches of sideoats grama or by wiregrass. Others were still in the early weed (mostly sunflower) stage.

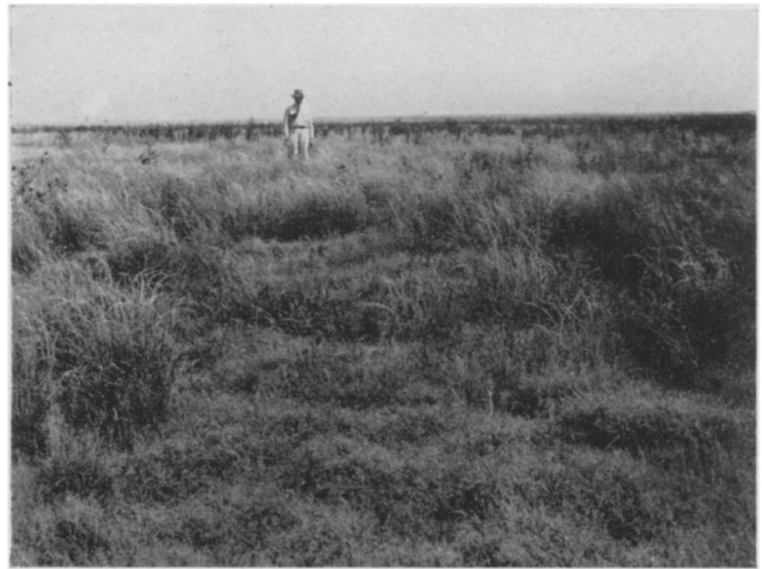

Fig. 96. View showing island of buffalo grass spreading in a general area of sand dropseed and dwarfing this mid grass. Note the presence of sunflowers and horseweeds (dark). July, 1943.

The upper portion of the hill had a much greater proportion of buffalo grass, since here it survived better because dusting was light. Weeds were almost absent from a large central area and from the upper western brow of the hill. The central portion, which continued along the entire length of the hill and varied in width from 150 to 600 feet, had a basal cover of 50 to 60 per cent (Fig. 97). Blue grama was more abundant than buffalo grass in the proportion of 3 to 2 , and the small amount of sand dropseed seattered thinly throughout was dwarfed and not flourishing. Where buffalo grass had sodded the soil between the bunches and patches of blue grama, the cover was more uniform and 10 to 15 per cent greater. Weeds in this central portion were represented only by last year's stems.

The west side of the hill was covered deeply with drifts of dust carried in by northwest winds from a field above. Practically all of the original vegetation died. It was covered with a dense stand of horseweed, lamb's quarters, western ragweed, and sunflower 1.5 to 2 feet tall. Buffalo grass had scarcely entered this area but large bunches of side-oats grama, sand dropseed, and blue grama did occur but were spaced several feet apart. Some of the relict bunches of side-oats grama were 20 by 30 inches in basal diameter and spread of the tops was 3 to 4 feet. Conditions on the deeply dusted east slope were very similar, although here sunflowers were much more abundant. Thus, on a single hillside were represented the early, medial, and climax stages of the subsere.

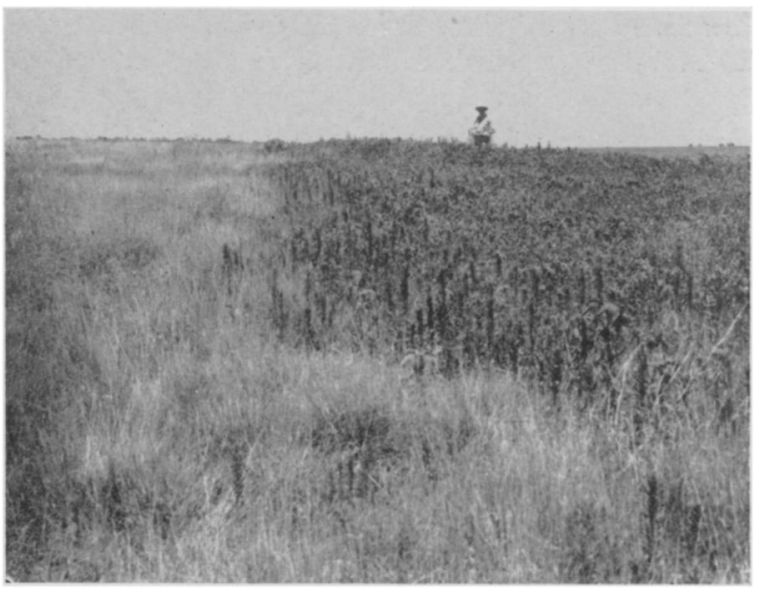

Fig. 97. Thinly dusted portion of the south slope of a pasture northwest of Norton, Kan., showing the recovery of short grasses ( 55 per cent cover) in July, 1943 The portion on the right, now clothed with Leptilon and other weeds, has deep drifts of wind-blown soil among which are large relict bunches of side-oats grama, blue grama, and sand dropseed.

\section{FIRST WEED STAGE}

Wherever the soil had been laid bare by drought or wind erosion or deposit, it soon became populated with annual weeds. Complete destruction was widespread. It occurred over thousands of acres in and about the dust bowl. Complete exhaustion of available soil moisture was the cause of death by drought; the high temperatures, low humidity, and excessive movement of desiccating winds combined to enormously increase water loss by promoting transpiration and direct evaporation from the soil surface. ${ }^{2}$ Plants that were watered did not die. Persistence of vegetation about snow guards (which were removed in summer) showed that its survival was due to the extra supply of moisture from the drifted snow. Here species of plants which died elsewhere often remained and sometimes maintained a nearly normal stature.

The intensity of the drought was amazing. In southwestern Kansas on extremely dry years vegetation made practically no growth in spring and early

2 For a full presentation of the environmental conditions during drought see Albertson and Weaver 1942. 
summer. Sometimes the landscape was green only a few weeks during the entire growing season. Over many square miles dust from tilled land completely buried the vegetation. Coverage to an inch in depth usually killed the short grasses. Ungrazed land was not exempt, for here the presence of a good cover caused the dust to lodge in mounds and drifts. In low grade pastures weeds played a similar role. Thus, on the level land mounds and ridges of earth 1 to 5 feet deep and many feet long were a haven for weeds, the seeds having been scattered widely by the terrible dust storms. These deposits of early drought furnished the source of material for dust storms in later years after the vegetation beneath them had died. Thus, not only was the dust removed but often the original, dry soil beneath as well (Fig. 98). Where vegetation had died of drought in overgrazed ranges and the rootcrowns and roots had disintegrated, the soil was so loose that wheat was drilled without any preparation of a seedbed. These were conditions for the early subsere. There remains also the fact that in the drier southwestern area such an environment, as regards lack or scarcity of perennial vegetation, still persisted in 1943 . It is illustrated by the following statements.

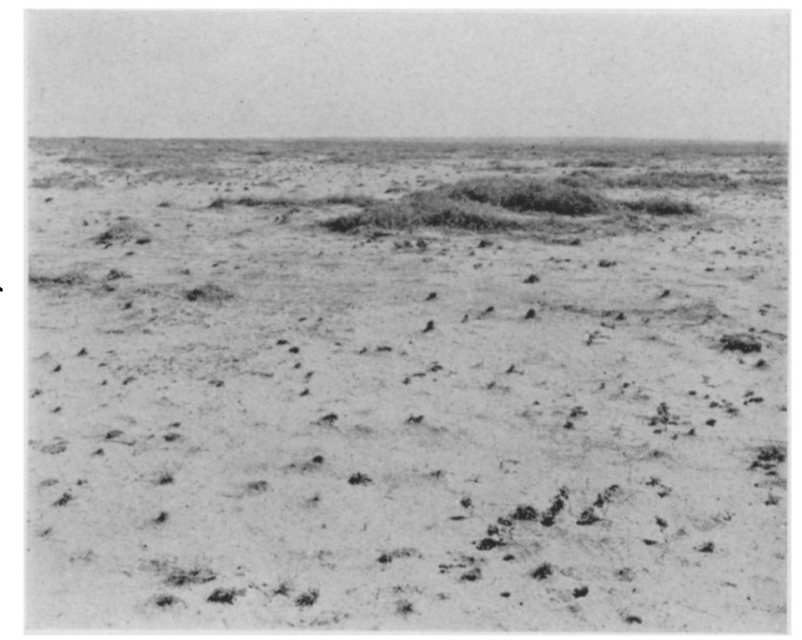

FIG. 98. Former short-grass range which had been buried under dust. The vegetation died. Later high winds carried the dust away and much of the top of the silt loam soil as well. The dead crowns of buffalo grass and blue grama are now several inches above the general soil level. This view is from Lamar, Colo., in August, 1939, but is typical of large areas throughout the midwest.

Near Lakin, Kansas, in late August of 1943, a wilderness of dead weeds from the preceding year was intermixed with a thick stand of sunflowers, lamb's quarters, Russian thistles, and other ruderals. Drifts of soil formed in 1935 still remained and were filled with the burrows of pack rats. Only a few small plants of blue grama, sand dropseed, and buffalo grass were found.

Near Sheridan Lake, Colorado, certain pastures were badly depleted by previous years of dusting.
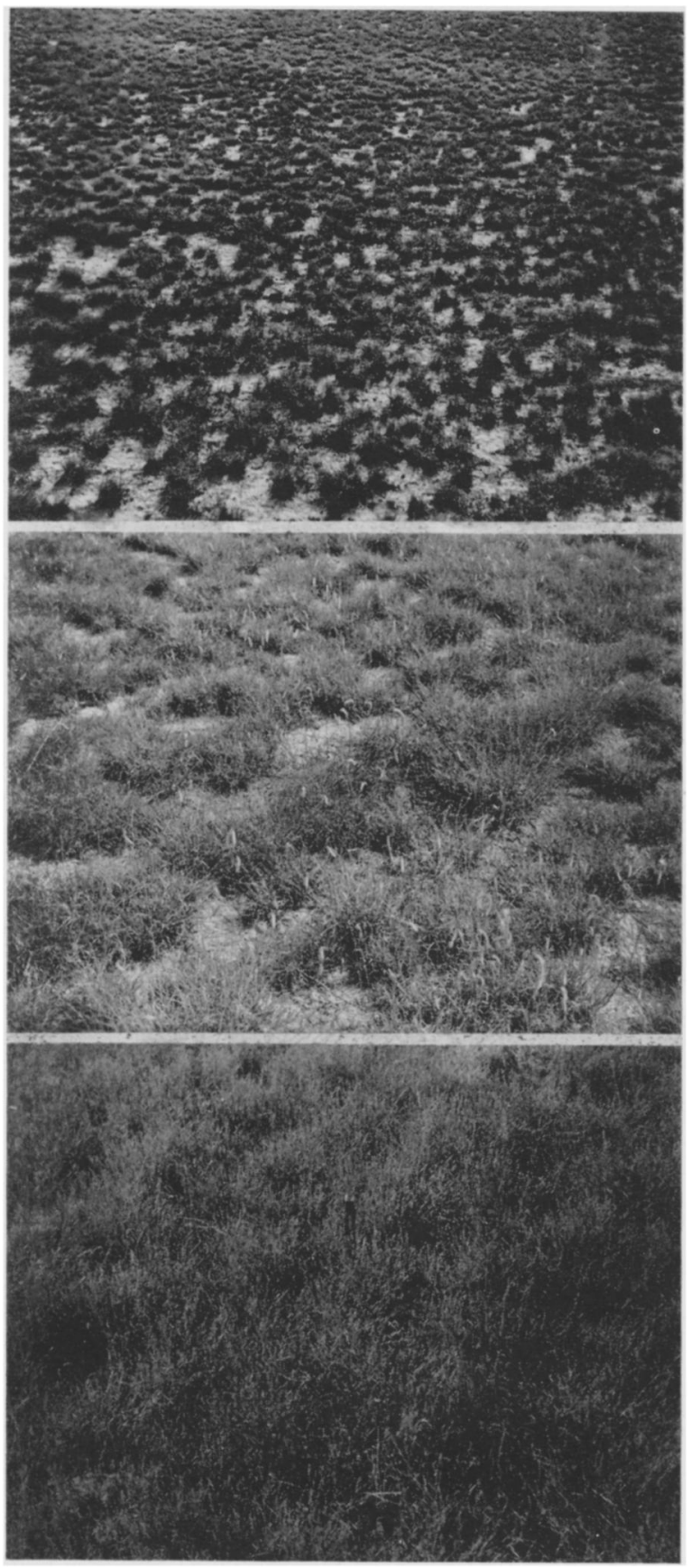

Fic. 99. Rapid recovery of range at Seibert, Colo., (upper), a formerly fine range of blue grama and buffalo grass with a basal cover of 85 per cent that had been reduced to 18 per cent in 1939 . Note the wide spacing of the bunches, of which about one-third are buffalo grass. (Middle) The same range in 1942. The basal cover has increased to about 30 per cent. (Lower) By July, 1943, the basal cover had spread more widely and was 55 per cent, although the excellent foliage gives the appearance of a nearly complete stand. The ratio of blue grama to buffalo grass has changed but little since 1942, when it was about 3 to 2 . 
Great drifts of soil 2 to 3 feet high and many feet in width were still populated with annual weeds. But scattered bunches of blue grama with a good crop of seedlings, patches of buffalo grass even if widely separated, and the presence of sand dropseed and tumblegrass portended a better future cover. But in the vast area lying northward and eastward of this drier part, succession had proceeded rapidly, the short-grass stage had been reached, and often all but the last traces of the early and medial stages in succession had disappeared (Fig. 99).

\section{Salsola Pestifer}

Russian thistle was the most abundant of all the weedy annuals during the dry years. It is a ubiquitous species of bared soil, regardless of its origin. The seedlings appeared in rather late spring but the top of the plant did not spread much until midsummer. Of the densely crowded seedlings, most succumbed and others were suppressed, since the dominant ones often attained large size, sometimes 3 feet or more in height, and the diameter of the more or less spherical top not infrequently reached 3 to 4 feet. But usually the plants were smaller and often dwarfed to only a few inches in height during extreme drought. This species has fleshy leaves and is very drought resistant. Normally the stems break off near the ground line in fall, unless the plants are overtaken by drought. Then they tumble across the wide level country, scattering seed as they travel. They lodge in great numbers against fences, weeds, drifts of dust, and elsewhere. Often fences are broken down or covered with dust, or traffic on the highways stopped, because of an accumulation of these pests. But if the tops were grazed or mowed when the plants were half grown and not yet spiny, they remained rooted and continued growth. They have much value as forage during drought, either for grazing or when cut early for hay. Mowing is prac-

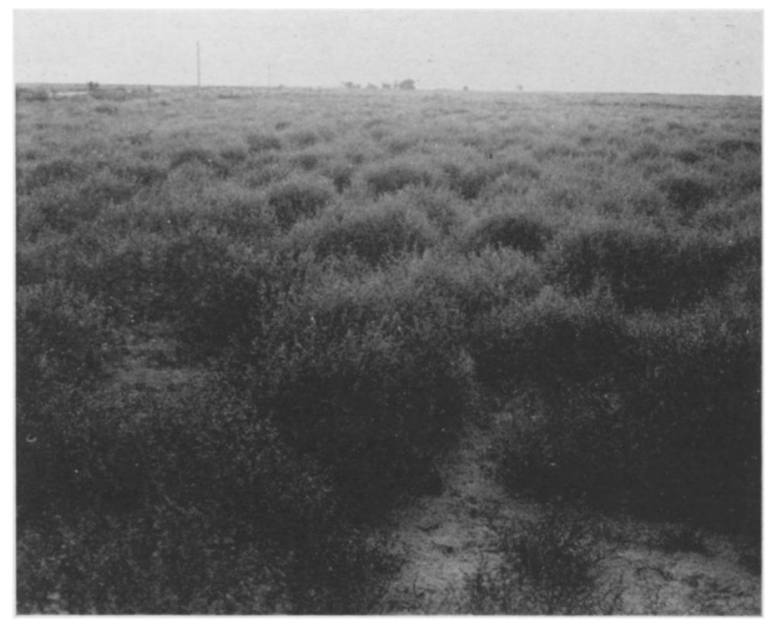

Fig. 100. Pasture near Boise City, Okla., on nearly level land that has been covered with silt and again uncovered. It is indistinguishable from the highway from weedy tilled land. Many of the Russian thistles were growing on drifts of soil. ticed in reseeded areas to keep the plants in place as a protection to seedling grasses from wind and direct sunshine.

By late summer Russian thistles often occurred in practically pure stands since nearly all annual competitors had been overcome; some had been actually pushed aside by the enlarging erowns. This species alone or almost alone covered hundreds of square miles of the dust bowl, and occurred widely in all the mixed prairie area (Fig 100). On many former ranges it was the early subsere, since it alone composed the vegetation. In fall and winter the dried plants accumulated in great windrows held by drifting soil, in ditches, or wherever else they had been blown; the rest of the range was bare. But on wet years with a cool spring, as 1941, they did poorly. Their invasion into true prairie ceased abruptly in 1942-43, and seedlings were not found even where the old plants had lodged. With continued good rains and the recovery of short grasses they have practically disappeared from the better ranges in mixed prairie as well. But they still persist in the drier, more open ranges of the southwest, often in large numbers.

\section{Chenopodium Spp.}

Lamb's quarters, Chenopodium album, and narrowleaved goosefoot, $C$. leptophyllum, were perhaps the most abundant of all annual forbs on wet years. Seedlings did not appear until the soil became warm. The plants developed rapidly, forming a tall dense cover by midsummer. A common height was 3 to 5 feet when moisture was plentiful, but on dry years there were dwarfed plants only 6-12 inches tall. They cast a dense shade and seedlings or recovering grasses were often greatly handicapped by their presence. Mature plants dried and remained standing another year unless blown over or weighted down by snow or dust. They were very widely distributed and usually abundant in bared soil.

\section{Amaranthus Spp.}

Rough pigweed, Amaranthus retroflexus, locaily known as redroot, was of common occurrence and an important component of the weedy vegetation. It ranged in height from 1 to 3 feet. Like the preceding, it furnished some forage, although it is said to be poisonous to stock under certain conditions. When mowed high it furnished a nurse crop for seedling grasses. A. graecizans is of smaller stature and somewhat bushy in habit, but of very wide distribution. A. blitoides, also common to abundant in open ground, is a mat-former much like purslane.

\section{Helianthus Annuus}

The common sunflower became very abundant in depleted ranges and largely replaced $H$. petiolaris on the hardlands since this native annual species, although formerly extremely abundant, withstood drought poorly. Pure stands covered large areas of much degenerated range lands. Like most weeds it grew best when the soil became more or less per- 
manently moist in 1941. But the size attained in the windswept ranges was rarely more than 4 to 6 feet (Fig. 101). This, however, contrasted sharply with most other weeds and especially with the relict patches of short grasses sometimes scattered beneath even a thick stand.

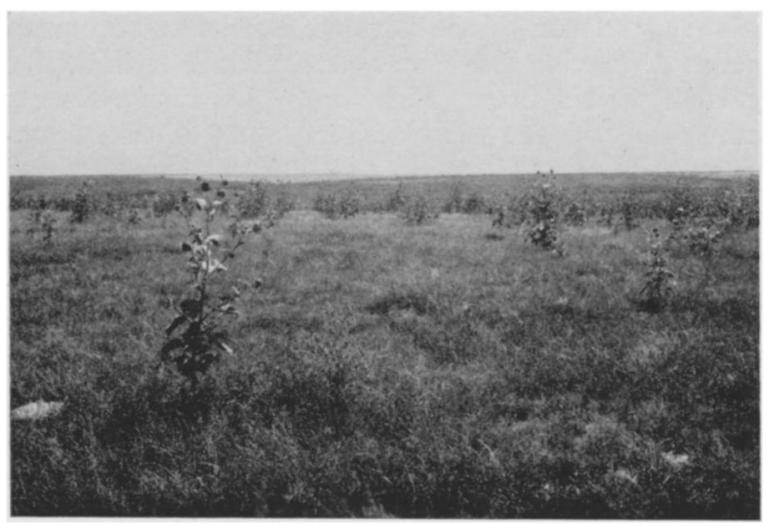

Fia. 101. Much disturbed range near Scott City, Kan., with weeds and sand dropseed in the foreground; also common sunflower which thickened its stand greatly in the background.

\section{Monolepis Nuttalliana}

Chief among the low-growing plants were Monolepis nuttalliana, Portulaca oleracea, and prostrate species of Chamaesyce. Monolepis is a prostrate plant which developed circular mats a few to 15 inches in diameter. It consisted of prostrate branches which under conditions of drought grew only a few inches above the soil. Its color was greenish-red. This annnual began growth in fall and renewed development early in spring, usually in April. It matured and dried in June. These weeds aggregated densely, sometimes completely obscuring the bare soil (Fig. 102). They competed for light with grass seedlings but not with established grasses. Where they occurred, they gave a distinct tone to the landscape. During their short life they retarded erosion by both

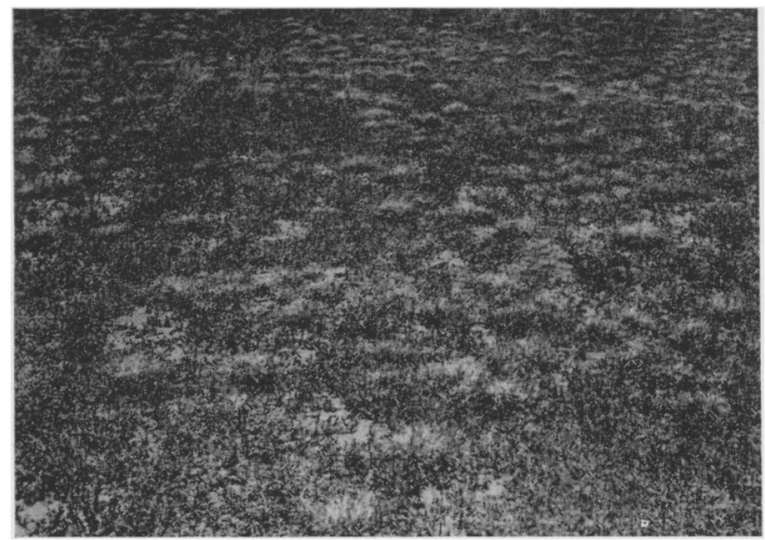

Fig. 102. Much depleted range near Winona, Kan., with a few scattered bunches of short grasses and an almost continuous cover of Monolepis nuttalliana. May 27, 1939. wind and water, and also furnished some forage. When dead they mulched the bare soil for a long time. They were intermittent in distribution but occurred widely, and often formed nearly pure stands.

\section{Portulaca Oleracea}

Dense patches of purslane, often covering many acres, gave the otherwise bare hillsides a reddish color in June. But these striking alternes also recurred in July and August, following showers. Like the preceding, they were early subsere plants associated with a warm dry soil. This succulent plant grew rapidly and formed extensive low mats. Its abundance was less than that of Monolepis.

\section{Chamaesyce Spp.}

The chief species of spurge or carpet weed found on the bare soil were Chamaesyce glyptosperma, $C$. stictospora, and $C$. geyeri. All formed widely spreading mats on bare soil and gave it considerable stability. Where seed germinated in small bared places surrounded by accumulated debris of weeds or last year's grasses, the stems frequently elongated 6 to 9 inches and the mats spread like umbrellas over the supporting debris.

\section{Solanum Rostratum}

Buffalo bur is a weed that was formerly confined largely to feed lots, corrals, and waste places. It often occurred widely in low grade pastures, especally in bared ravines. In some ranges this prickly annual aggregated into dense patches, elsewhere it was found intermixed with other weeds. It is a large, coarse, native annual of no forage value but of good drought resistance. It was of considerable importance in the annual weed stage.

\section{Leptilon Canadense}

Horseweed has played an important part in the subsere almost everywhere. While it occurred abundantly in the early stage, it was represented in later stages as well, and persisted as long as there were small bare spots among the grasses where the seeds could reach the soil. Typically it was a species of open land. A moist spring was usually essential for good establishment. It responded quickly to an increase in soil moisture and one could closely estimate the favorableness of the season by the height growth of this weed. The plant was usually single-stemmed but very leafy, unless it had been bitten off, usually at a height of several inches. It then responded by producing a bushy top of many stems. Where the cover was open the plants densely aggregated, the height varying from 5 inches to 5 feet (Fig. 103). The weed thus not only formed dense patches, often of great extent, and hindered growth of seedling grasses and the spread of stolons, but it also gave the range a distinetly irregular and ragged appearance. It continued growth until fall if water was available, otherwise it often withered and died early. It was distinctly cyclic in appearance, sometimes failing to occur where dead stems revealed that the 
plants were abundant the preceding season. But it was sometimes plentiful the next year. It disappeared entirely only when perennial grasses gained possession of the soil (Fig. 104).

All of the preceding annual weeds have played an important role in temporarily stabilizing the loose, dry, wind-blown or water-eroded soil. Practically all were grazed, in fact over thousands of acres they were the only forage available for starving cattle in the worst denuded pastures. But the food value was low, and during the driest years even these weeds were dry during summer. Range examiners often estimated the carrying capacity of these weedy pastures in and near the great dust bowl as one animal unit per 80 acres.

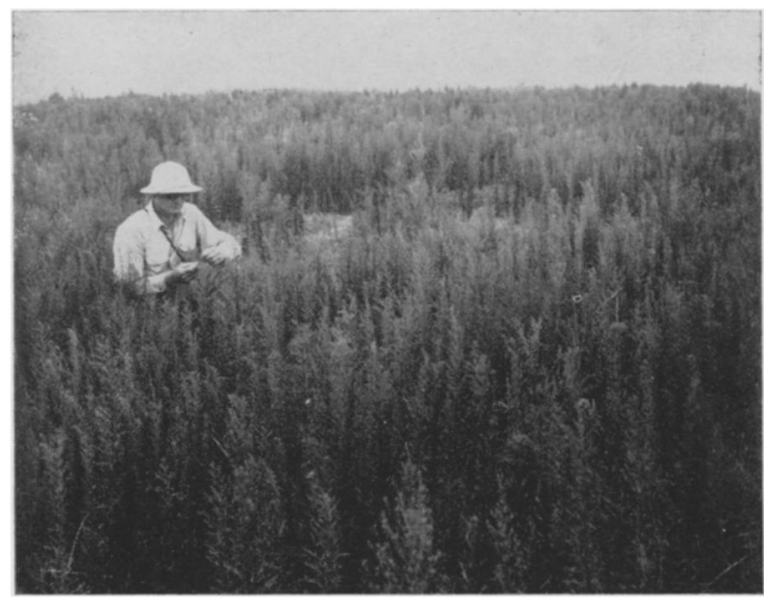

Fig. 103. Thick stand of horseweed (Leptilon canadense) near Rexford, Kan., in August, 1942. An open growth of short grass grew beneath these weeds.

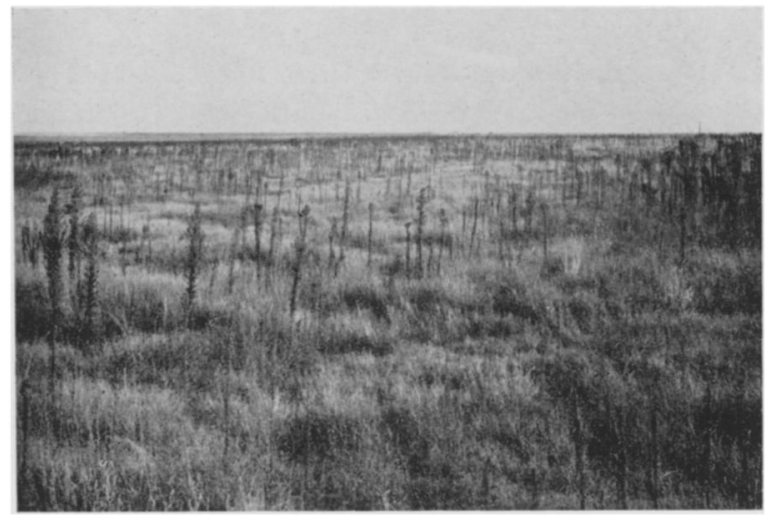

Fig. 104. Scattered growth of horseweed near Oak. ley, Kan., where a dense sod had replaced an open stand of grasses and relatively few bare places remained for the germination and growth of weeds. August, 1942.

\section{SECOND WEED STAGE}

Depleted ranges were usually heavily infested with a diverse population of weeds. Sometimes a plant which was found more usually in the second weed stage, for a time also thickly populated bare soil. This was true of Lepidium densiflorum. On other ranges where much bare soil occurred between patches of grass which in the aggregate formed a moderately good cover, Russian thistles or other species of the early weed stage were found. But species listed under the second weed stage usually dominated more stable areas than the preceding ones. In spring especially, the cover of weeds gave the appearance of excellent pasturage. Much of this aspect was due to little barley.

\section{Hordeum Pusillum}

Little barley played a role of enormous importance during drought. This winter annual varied in height from 8 to 16 inches on wet years but was often only an inch or two tall on dry ones. It practically always succeeded in heading, however, before the moisture supply was exhausted. Its myriads of slender, unbranched stems covered the soil in very early spring and furnished fairly good grazing. But early in June and for many weeks thereafter dense yellowish patches, alternes, or continuous stands of dried plants gave many ranges the appearance of a stubble field or a field of headed grain. The amount of little barley varied greatly by years and locality but it occurred everywhere.

Little barley was very detrimental to the growth of seedling grasses and the establishment of short grasses as well. Like other rapidly growing weeds, it absorbed large amounts of water from the surface soil and produced a thick layer of vegetation which not only shaded the soil but in addition intercepted much precipitation. The large amounts of water lost from the soil on which a thick stand of little barley grew were ascertained. Conditions and time of the experiment were the same as those described for downy bromegrass. Losses were only a little less. Those from the soil were 41 pounds per square foot or 893 tons per acre from March 27 to May 8, 1943, at Lincoln, Nebraska. Interception losses amounted to 0.53 pound per square foot of soil or 11.54 tons per acre.

Under little barley the shade was dense; often only 1 to 3 per cent of full sunshine reached the soil. The dried straw continued to obstruct the light for seedlings and all low-growing vegetation. When it lodged, chance for survival of seedlings beneath it was still further reduced. Dead seedlings of sand dropseed and other grasses have been found repeatedly under a cover of little barley. Often there was no vegetation under the cover but great quantities of fallen spikelets. By clipping and weighing the yield of little barley, it has been found that this weed may produce 1 to 2 tons of forage per acre per year.

Earlier in drought little barley occurred abundantly all over the drought-stricken ranges. In 1941 it was found in the more favored sites only, and disappeared almost entirely in Colorado. But it was again abundant in 1942-43. This grass is a native species and a normal component of the short-grass cover. There are always small interspaces in the perennial sod where seed can contact the soil and here little barley thrives. 


\section{Panicum Capillare}

Unlike little barley, witchgrass is an annual of large stature and grows only in open ground. It is not found in grassland even where the cover is only moderately good. This plant indicates much disturbed conditions and it has been an important species over great areas of range land. The size attained varied with the water supply. Small plants a foot high were common but those with a stature of 2 to 3 feet and spreading tops so close that they formed a nearly complete cover also occurred. They were rather patchy in distribution on silt loam and thrived best on lighter soils.

\section{Eragrostis Cilianensis}

Stinkgrass is a semiprostrate grass under grazing and trampling but when undisturbed grows more erect forming small bunches. This summer annual is easily shaded out and gives way even to a stand of sand dropseed. If water is available it remains green until fall and furnishes some forage where better grasses are few.

\section{Festuca Octoflora Hirtella}

This variety of six-weeks fescue is a shorter and more spreading plant than Festuca octoflora. It was an important component of the second weed stage.

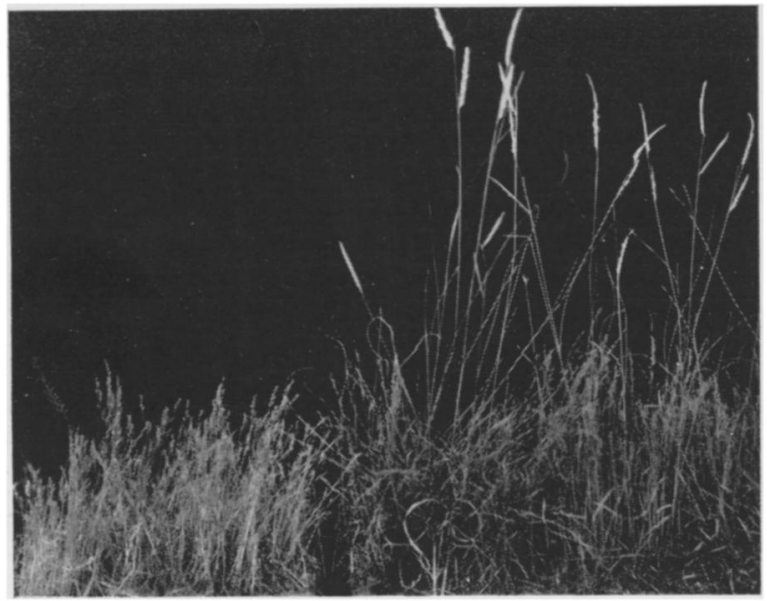

Fig. 105. Detailed view of small clump of six-weeks fescue (Festuca octoflora hirtella) from a small interspace in blue grama sod (left), and a thin stand of the same grass growing with blue grama (right). From a range near North Loup, Neb., August, 1943.

In many ways its behavior was similar to that of little barley. The variety was far more abundant than F'estuca octoflora in mixed prairie, but was usually not found east of Hays and Holdrege. It often populated wide areas of open soil but unlike many early subsere weeds was also an important member of the second weed stage. The densely aggregated stalks of this annual clothed the bare places, whether small or large, that occurred between the tufts of short grasses. A thin growth was also scattered in the clumps of short grass (Fig. 105). When it dried it was usually plentiful enough to give the range a tinge of brownish yellow even when the short grasses remained green.

\section{Bromus Spp.}

Species of bromegrass, which were so very important in the subsere in true prairie, also occurred on many ranges in the eastern margin of mixed prairie. They were not infrequently of considerable abundance, especially downy brome or chess (Bromus tectorum), Japanese chess (B. japonicus), and later, hairy chess (B. commutatus). Upon drying and lodging they formed a thick mulch over the bared soil.

\section{Lepidium Densiflorum}

Peppergrass produced continuous dense stands over many acres. Sometimes it was the sole species but usually there was an understory of an open stand of blue grama. It was widely distributed and grew in such abundance immediately following drought that it was very important in soil stabilization. Throughout mixed prairie it formed continuous stands over many acres (Fig. 106).

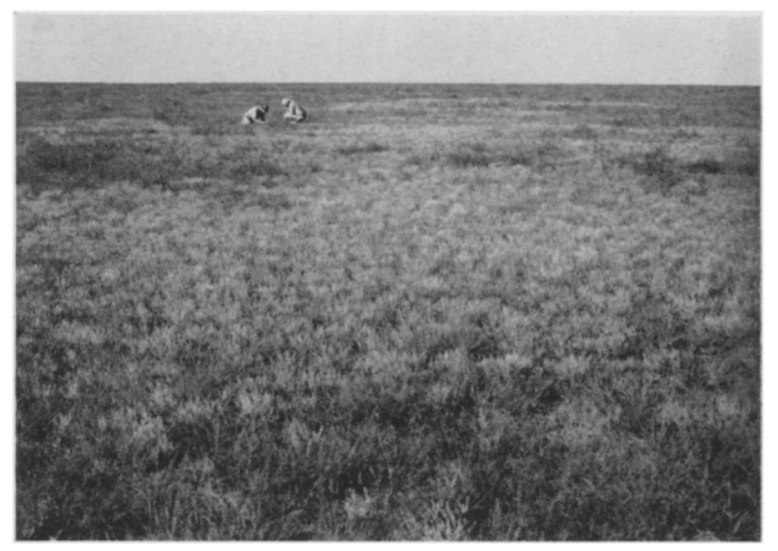

Fig. 106. One of the thousands of patches of peppergrass (Lepidium densiflorum) found in the midwestern ranges during the years of great desiccation. This one is near Cheyenne Wells, Colo., and was included in the seedling survey made in June, 1941. The peppergrass is about 6 inches tall and there is a cover of 1 to 3 per cent short grass beneath it.

The plants were 5 to 8 inches tall and grew so thickly that they obscured the grasses beneath. Density of stand of this species always increased with sparseness of the perennial grass cover, which was often only 1 to 3 per cent. The fallen seeds were sometimes so abundant that they completely covered the soil. Often the leaves of the grasses were splattered with the seeds which are mucilaginous when wet. Newly dried plants were straw-colored, older ones were a drab gray. Great alternes on the barer slopes were composed of this weed, and in places they covered the entire pasture. Frequently 160 plants grew on a single square foot. As late as 1941 it still grew thickly in the more easterly ranges of mixed prairie, but westward it was replaced largely by species of stickseed and cryptantha. 
Plantago Spp.

Pursh's plantain (Plantago purshii) and spinulose plaintain ( $P$. spinulosa) formed dense patches on disturbed ranges. Often these species and peppergrass were the worst weeds. In such ranges the soil covered by the densely aggregated annuals was much greater in area than that clothed with the native grasses. Dense patches and alternes gave the landscape a grayish appearance in June when the spikes became prominent. These plants are grazed only when young and before the hard spikes have matured.

\section{Lappula Spp.}

The stickseeds (Lappula occidentalis and L. heterosperma) when green may grow so thickly as to completely cover the soil. On dried plants the leaves shrivel or fall and the much-branched stems and spiny fruits are only prominent (Fig. 107). The drab

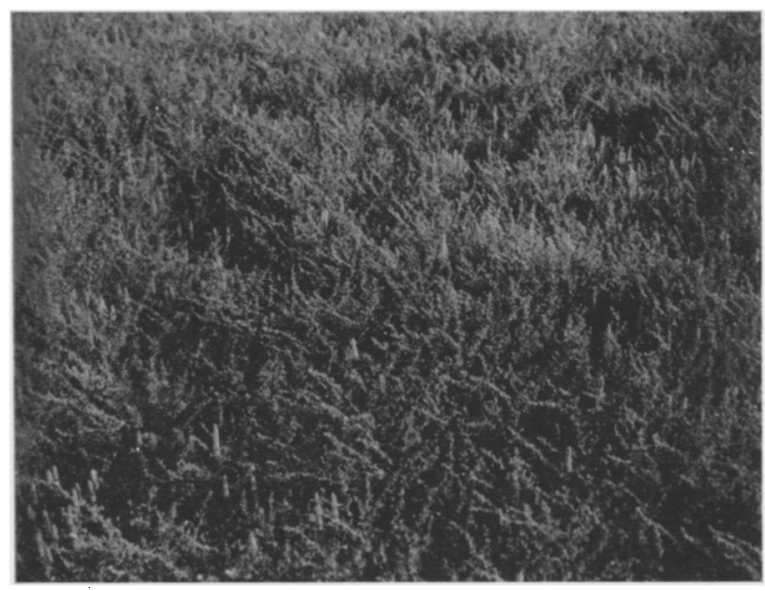

Fig. 107. Dense cover of stickseed (Lappula occidentalis) 8 inches high near Arriba, Colo. A 2 per cent cover of short grasses occurred beneath.

color of these winter annuals demarked in early summer innumerable areas of a few square feet to many square rods, if indeed they did not give tone to the whole landscape. Beneath this thick weedy growth, often about 8 inches high, occurred the depleted stands of grasses. The density of the grass cover was usually inversely proportional to the thickness of the stand of weeds. Stickseed was especially abundant in western Kansas, and Colorado.

\section{Cryptantha Crassisepala}

This harsh borage is often associated with Lappula or alone covers much bared or partly bared soil. Millions of seedlings often appeared in dense patches in fall and remained green throughout the winter. After a few weeks of growth in spring, seed was produced and the plants dried. The color changed first from green to gray and then to black. Plants sometimes attained a height of 8 inches but were often only 3 to 4 inches tall. They usually aggregated densely but were often thinly scattered over the depleted ranges. The dead plants remained standing for a long time.
Discussion

All of these quickly maturing, weedy plants-little barley, peppergrass, stickseed, and cryptanthafrequently grew even in the best remaining patches of blue grama and buffalo grass, as well as more densely between them. They formed either a discontinuous, patchy layer above the grasses or overshadowed them entirely throughout the entire range. They were often accompanied by an abundance of six-weeks fescue. They were of little value for grazing and upon drying became highly undesirable. Lappula and eryptantha were not eaten nor was the grass under a dense stand of these weeds. Yet the preceding weeds usually formed, during drought, the major components of the plant cover. Studies on the yield of ranges in western Kansas near the end of the drought have shown that while a ton or more per acre of peppergrass, stickseed, Russian thistle, and other weeds was produced, the yield of native grasses was often only 200 to 300 pounds.

The amount of the winter annuals, and indeed their occurrence, was highly dependent upon soil moisture for germination and conditions for growth in early spring. Those which germinated and normally grew often failed to do so if the spring was cold or dry. They usually failed to appear later even if good rains fell in late May or June. Thus, their abundance and very presence fluctuated greatly. They were a scourge on many ranges in 1940-41. In fact, the harsh, prickly plants and fruits almost excluded the possibility of grazing over wide areas. This, of course, was favorable to the weakened grasses. But with the increased rainfall and lower spring temperatures peppergrass, lappula, cryptantha, and plantain as well disappeared or nearly disappeared except in the drier area in southwestern Kansas and adjacent territory.

While annual weeds were often abundant in great patches or even continuously over many greatly damaged ranges, in others they were thinly scattered and not infrequently sparse, greatly dwarfed, or killed by drought. Water content of the soil and seed distribution were the chief controlling factors. A few less dry years, as 1935 and 1938, were interspersed between those of grave moisture deficiency. Moreover, precipitation in this semiarid region was frequently local in distribution and of erratic occurrence during the growing season. Nor did seeds even of all the weeds occur everywhere. But weeds did compose all, nearly all, or the larger part of most of the vegetation, depending upon the degree of destruction of the native grasses (Fig. 108). Native forbs were always scarce and all but a dozen of the most drought enduring species disappeared. But with the return of normal precipitation, and often two or three times the normal in spring and summer, grasses began to reclaim more of the area and bare spaces for annual weeds rapidly decreased. In this change of plant population not only did the climax grasses play a part but also a number of species which composed the early native grass stage. 


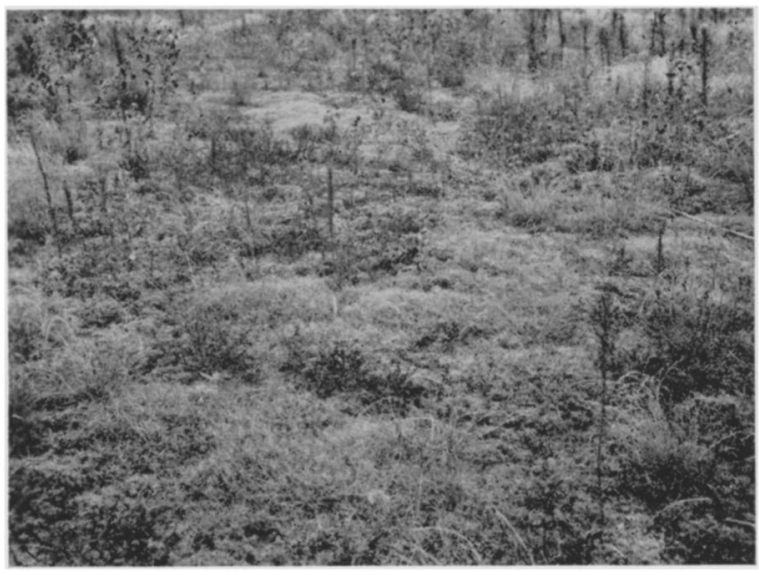

Fig. 108. Mixture of weeds-Russian thistle, horseweed, sunflower, and others. The patchy cover of buffalo grass and sand dropseed totaled 20 per cent. Range north of Syracuse, Kan., August, 1942.

\section{EARLY NATIVE GRASS STAGE}

With the appearance and increase of perennial grasses of the early native grass stage, good progress toward stabilization has been made. For these plants are not only longer-lived but they maintained a much better cover from year to year than did their predecessors. Their fibrous roots more firmly held the soil than did the tap roots of the preceding weeds or the shallow fibrous roots of the annual grasses

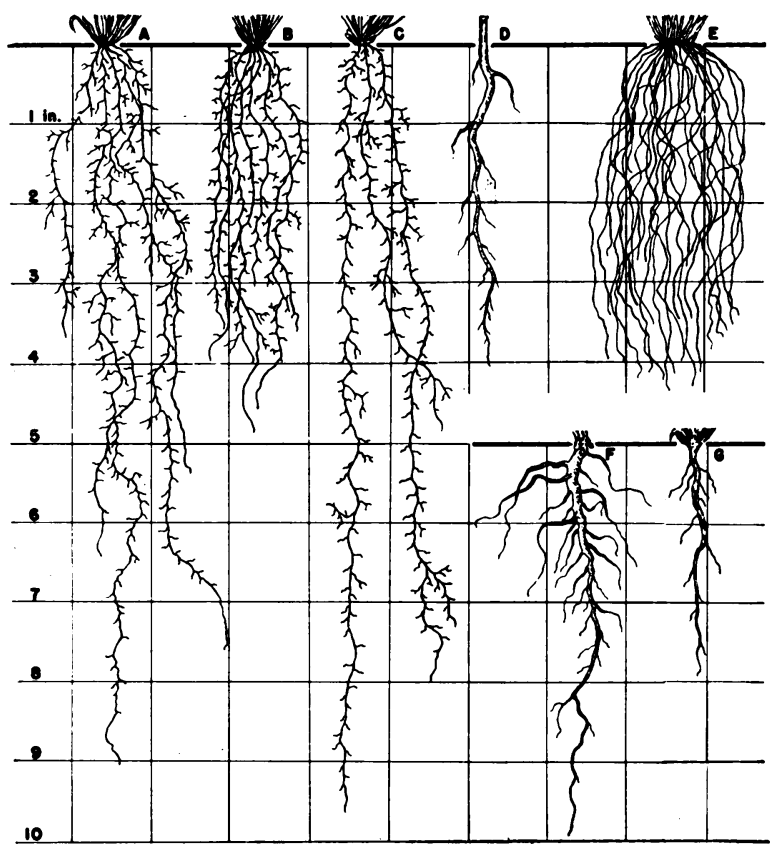

Fig. 109. Root systems of first year seedling grasses and annual weeds in an open cover of short grass at Hays, Kan., on August 1, 1938 . (A) buffalo grass, (B) sand dropseed, (C) blue grama, (D) peppergrass, (E) six-weeks fescue, (F) stickseed, and (G) Pursh's plantain. Conditions for growth were very favorable until the late July drought. The weedy annuals (D to G) had died and the finer roots, which were few, had disintegrated and are not shown.
(Fig. 109). Nor did they grow so thickly and shade the soil with its seedling population so greatly as the annual weeds.

\section{Sporobolus Cryptandrus}

By 1940 sand dropseed was the most widely spread and most abundant of the minor perennial grasses. Previous to the drought, it was usually restricted to sandy soil. But with the advent of the dry period vast areas of soil were laid bare. Into this warm, loose, usually dry soil sand dropseed spread widely, especially after 1939 when the plant cover was again greatly reduced. It increased very greatly since the drought and is now exceeded in abundance only by blue grama and buffalo grass. While on some ranges only a few bunches were found, and in others it was confined to the "catsteps" or rougher land, more often it was found abundantly and not uncommonly in almost pure stands. Indeed, the sporobolus type of grassland was common (Fig. 110). Thickness of stand was somewhat proportional to the original degree of destruction of the cover. It thrived in dusted pastures. Where open spaces occurred, it was still spreading in 1943 by an enormous crop of seedlings.

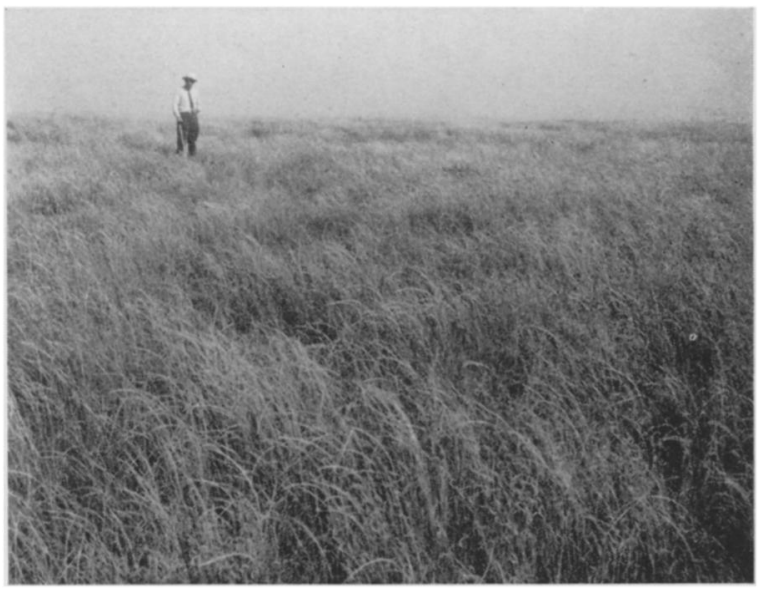

Fig. 110. Sand dropseed (Sporobolus cryptandrus) in much disturbed range near Levant, Kan. It forms about 60 per cent of the vegetation; the rest is short grasses.

Sand dropseed is a prolific seeder and its seedlings have often persisted along with those of the short grasses when nearly all others succumbed. Two- and three-year-old tufts were found regularly in 1942-43. It tillered so freely that the bunches increased rapidly in size. In the 1940 seedling survey, for example, this species occurred in 103 of the 550 square-foot samples, blue grama in 132, but buffalo grass in only 34. Aside from Schedonnardus paniculatus (24) these were practically the only perennial grass seedlings found. But in number (592) sand dropseed exceeded even blue grama (518). In the following years its seedlings occurred so thickly in places (20 to 30 per square foot) that they seemed to have been sown by hand. Thus, this grass was of extremely great importance in the subsere. Its percentage of the basal cover where it was intermixed with short 
grasses was commonly 5 to 20 . Where disturbance was greater or soil type lighter, this rapidly increased to 50 per cent or more, and many ranges with $80-90$ per cent sand dropseed and only remnants of short grasses have been examined.

This grass is only a semiclimax species. It has never been observed to decrease in size or numbers in a thickening stand of blue grama. But this will probably occur when blue grama forms a more complete sod. Sand dropseed yielded readily to the rapid invasion of buffalo grass when it formed a dense sod. This has been observed repeatedly both in and outside of quadrats, in fact, on almost every day of field study since 1942 (Fig. 111). Weak, scattered plants were common where a cover of 80 or more per cent of buffalo grass or mixed short grasses had developed. Under such conditions the lower 3 inches of old plants were covered with debris of dead grass.

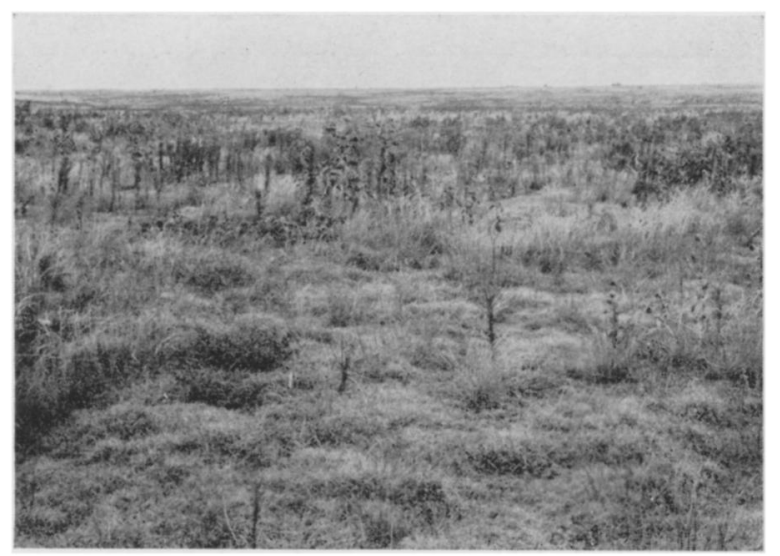

Fia. 111. Range near Syracuse, Kan. Sand dropseed became very abundant here in 1940 . But by 1942 buffalo grass had increased so greatly that it had replaced much of the dropseed. Small weak bunches, often with very few stems, and dead plants were common.

They were first dwarfed in stature, then fewer and fewer stems developed in spring. Relict plants with only 1, 2, or 3 stems were easily found on bunches with a good base. Finally, old crowns without new stems revealed the last stages of its suppression. Then the range with irregular height of cover and consequent patchy and ragged appearance took on the low monotonous aspect of well grazed pasture. But in many places the sand dropseed stage in succession has only recently been attained and its replacement by other grasses remains for the future.

The grazing of patches of sand dropseed to the neglect of the more palatable short grasses which were ungrazed the preceding year is of interest and quite common in occurrence. It results from the fact that the sand dropseed had been grazed and repeatedly regrazed the previous year (or very early in spring) while the short grasses had been neglected. Thus, a poorer quality of green forage is often selected by cattle in preference to a better one intermixed with dry leaves.
Agropyron Smithii

Western wheat grass was represented widely throughout the mixed prairie both before and during drought. Its rhizomes were present in the soil in favored places as regards moisture even where development above ground was much retarded by competing vegetation. When the sod was opened by drought, wheat grass often became plentiful (Fig. 112). On rolling land it occurred formerly on the border of the short-grass type, in the ecotone between this and the little bluestem type, and was also intermixed with little bluestem on its margins. Where underlying shale near the valley produced soil into which water penetrated slowly, wheat grass also occurred. From here it extended downward into the drought-damaged big bluestem type. Banks of dry ravines were also invaded. A third refuge of this drought evader was the buffalo wallows scattered throughout the short-grass habitat. But here the living rhizomes remained mostly dormant during the several years of drought, with little or no growth above ground. Since 1941 it has thrived and spread outward onto the level land where it formed an upper story to the open cover of relict short grasses.

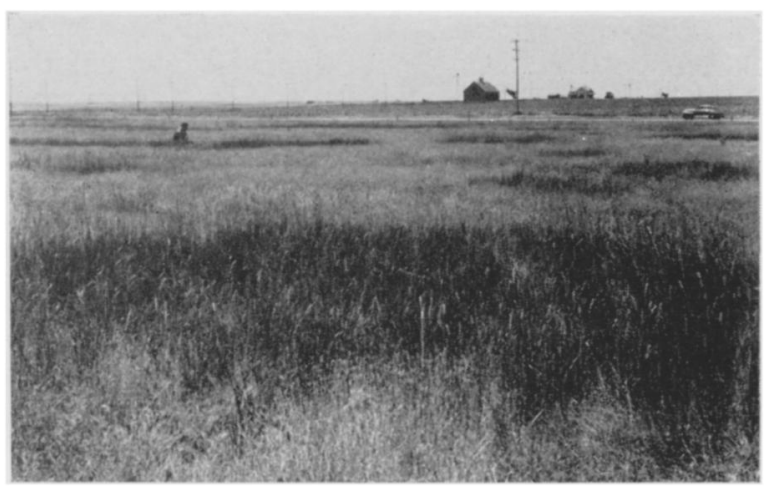

FIG. 112. Patches of western wheat grass (dark) in a disturbed range near Holdrege, Neb. There is also much little barley, but this grassland aside from the deeply dusted wheat grass patches is rapidly returning to short grass. July, 1943.

The extent of the invasion of wheat grass on uplands when the cover was broken was vividly revealed by its excellent growth here on the better years. In general, it is far more abundant on rolling than on level range lands. On level or gently undulating land one finds wheat grass where there is a slope into shallow basins. Such basins have always been much grazed and trampled, a fact that may account for the present dominance of wheat grass. Trampling, drought, and dusting are the keys that unlock an area for the entrance or spread of wheat grass. With rare exceptions, the relative amount of this grass on the level lands in Kansas west of Hays was small even in 1943. On the loess hills about Ravenna, Ord, and Broken Bow, Nebraska, for example, it occurred sparing.'y to abundantly in patches and alternes where it had popu'ated many droughtbared or dusted areas regardless of topography. In 
fact, throughout the rolling grasslani.s, streaks and large circular areas or whole hillsides and valleys were covered with this rhizomatous, drought evading grass.

\section{Schedonnardus Paniculatus}

Tumblegrass was commonly found before the drought in disturbed places, especially in overgrazed ranges, where it sometimes composed a considerable part of the cover. Although it is a dryland grass, it was unable to survive the great drought, and all but disappeared, often being replaced by sand dropseed. It formed small tufts or bunches, and after flowering the axis of the inflorescence elongated to $2-4$ feet on moist years and curved outward, often over the tops of adjacent short grasses (Figs. 87 and 8ß). In a few places it grew so thickly that when the panicles had expanded they formed a continuous layer over the 20 to 30 per cent cover of short grasses. The panicles break away from the plant and are spread far and wide by the wind. With the return of a normal supply of soil moisture, seedlings and tufts of tumblegrass became very abundant in the bare spaces between bunches of blue grama or mats of buffalo grass. Thus, much bare or weed-infested soil was again populated with a perennial grass. Sometimes the old crowns persisted during the drought, and in buffalo wallows the plants grew well during the less severe years of the drought period. But this species formed only a temporary cover since it was easily replaced by sand dropseed, wheat grass, and, of course, by the short grasses as well, even before a complete cover was attained.

\section{Munroa Squarrosa}

False buffalo grass almost disappeared during the drought. This grass has neither rhizomes nor stolons. Although the stems of this low-growing annual spread widely and under favorable conditions form mats 1 to 1.5 feet in diameter, they do not become rooted at the nodes. In dry soil the plants were relatively small. They occurred only in bared soil or open places between the perennial grasses, and did not

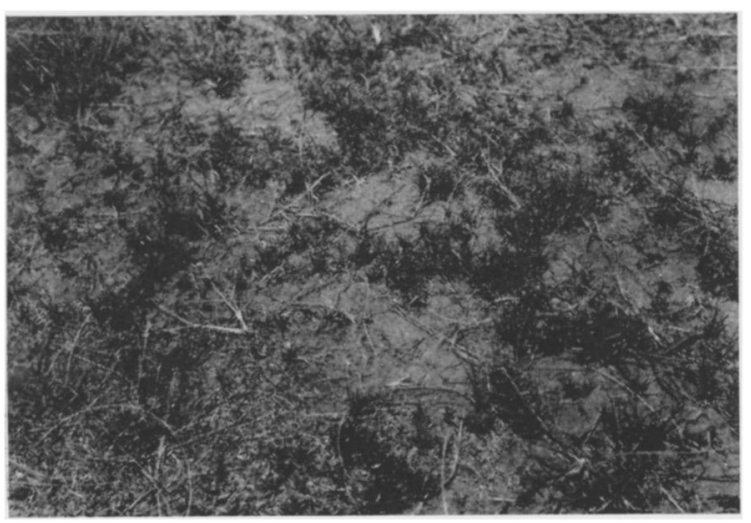

Fig. 113. Open stand of false buffalo grass (Munroa squarrosa) in hard open ground on a range near Stratton, Colo. The light-colored debris is from the flower stalks of tumblegrass. tolerate shade. Seedlings often died under the shade of tall weeds or other plants. Munroa thrived on hard and trampled soil, occurred in paths or around the large mounds built by agricultural ants. Its abundance varied widely with the amount of precipitation, but sometimes it occurred throughout large ranges (Fig. 113).

\section{Chloris Verticillata}

Windmill grass grew rapidly where th re was little competition except by annuals of low stature, and spread widely by means of the tumbling inflorescences. It often developed large bunches, but it was of less abundance than tumblegrass. It was seldom found in large amounts north of Kansas, and the soil became too dry for its existence in the southwestern area, where it disappeared rapidly. This grass was closely grazed even in fairly good pastures, and was often replaced by sand dropseed.

\section{COMPARISON OF STAGES IN THE TWO SUBSERES}

A brief statement concerning the shorter subsere, which occurred in ranges with one-fourth or more of the cover left intact, is necessary for the sake of clarity and to avoid repetition. For the late grass stage is the same in that subsere as in the one in more denuded ranges.

Comparison of the lists of species in the first stages of the two subseres reveals that none of those in the longer sere, except Salsola pestifer and Leptilon canadense, appears in the shorter one. This indicates that these annual weeds were of too little importance to be included as subsere dominants, although of course they sometimes occurred in ranges, or parts of pastures, but in small amounts. Russian thistles, which grew in the less disturbed pastures during the drier years only, were mostly plants of small size that were scattered thinly or thickly in the places where a perennial cover was lacking. Diaperia (Filago) prolifera is a small, early, annual composite which occurred in enormous abundance, often where sheep were pastured. Although found in all portions of the area, it occurred in great abundance in relatively few of the ranges. Leptilon canadense was present throughout both subseres and remained as a weed as long as there were even small open spaces in a good cover of the climax short grasses. In fact, where this tall annual was present, the openness of the cover could be gauged by its density.

Species of the first stage of the shorter subsere were largely those of the second stage of the longer one. The only exceptions are that Panicum capillare and Eragrostis cilianensis were not important in the sere in better pastures. When the scourge of Lepidium densiflorum swept over the grassland, the plants grew wherever they found lodgment in bared soil. This was true for Plantago and all the other annuals which occurred in both seres. They grew between the bunches or sod mats of both blue grama and buffalo grass since these were about the only relicts of much importance aside from the dormant wheat grass. They were all of enormous abundance on 
various drought years and filled the bare places sparsely to completely depending upon place, season, and rainfall distribution.

In the second stage of the shorter subsere species of Aristida and Sitanion hystrix were of some importance, in addition to those already discussed. Before drought both Aristida purpurea and A. longiseta occurred widely and often abundantly over the shortgrass disclimax. But with the coming of severe drought, these shallowly rooted bunch grasses were among the first to show the effects of a decreased water content. Some remained in somewhat sandy soil until 1939. But they finally disappeared from the hard lands and persisted elsewhere only where they were protected by other vegetation or as a result of irregular topography. A. purpurea, the species with taller and more upright stems, was less drought resistant and had recovered more slowly from drought than $A$. longiseta. Many young plants and bunches were found in 1942 and a year later they were comomn in many places (Fig. 114).

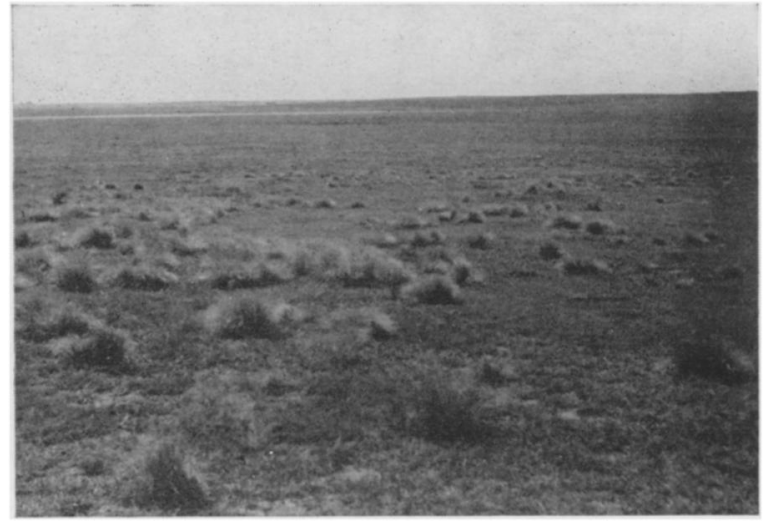

Fig. 114. Wire grass (Aristida purpurea) scattered over rather low open ground in a broad expanse of grassland near Burlington, Colo. July, 1943.

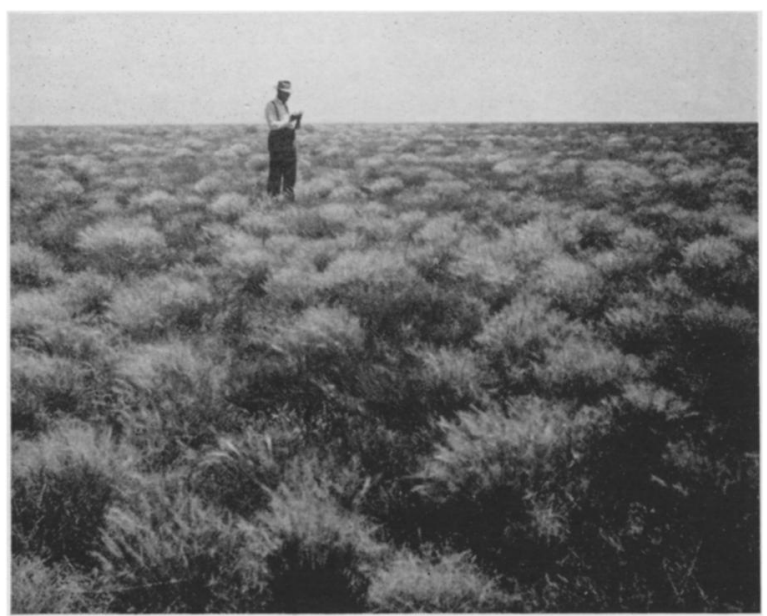

Fig. 115. Thick stand of wind-blown Sitanion hystrix in a range near Anton, Colo., in July, 1943. The stand will become greatly thinned when the cover of short grasses is repaired.
Squirreltail (Sitanion hystrix) is also a bunch former but was formerly less plentiful than the wiregrasses. It survived the drought poorly and only in rough or rocky terrain. Many young plants with only one or two spikes were found in 1943 , but in a few ranges recovery was earlier and more rapid and the plants were very conspicuous and abundant (Fig. 115).

\section{IAATE GRASS STAGE}

The development of the late grass stage is primarily a story of the return of blue grama and buffalo grass. These grasses today, as before the drought, are the most abundant grasses of the midwestern ranges. Before the drought, mid grasses were scattered throughout, mostly sparingly on the grazed hardlands. But during the drought cycle they practically disappeared (Weaver \& Albertson 1940). After three years favorable for recovery, they are only beginning to return. It was the short grasses that persisted as relicts and they almost alone were replacing the cover of this great grazing disclimax.

\section{Bouteloua Gracilis}

During the great drought when all other native vegetation had succumbed, one could nearly always find scattered bunches of blue grama. Sometimes they were as much as 20 feet apart, but in certain ranges they remained in considerable abundance even if widely spread. The bunches were separated in winter by bare soil and in summer by a mixed stand of annual weeds. Most of these bunches endured until 1939, often being elevated 1 to 3 inches above the ground where the top soil had been blown or washed away (Fig. 116). Bunches or clumps of buffalo grass, when present, were likewise elevated and also subjected to excessive drying of the soil about the roots and rootcrowns. But unlike blue grama they could still spread by stolons contacting the surrounding soil. Limits of spreading of blue grama were circumscribed. The peripheral tillers sometimes extended outward nearly horizontally but roots could not reach the soil. In wet weather it might have been possible for fragments of the bunches to have been broken off by trampling and thus transplanted near the old ones, but no such process was observed. Bunches, usually not thus elevated, grew to very large size, 10 to 12 and rarely 18 inches in diameter. They were important in holding the soil and, on favorable years, a source of much seed.

When good rains came in 1941 the bunches of blue grama everywhere produced many new roots which grew outward and downward from the crowns or penetrated the soil directly beneath them. They reached a depth of 18 to 21 inches by autumn and thus reinforced the much-thinned and scanty root system found at the end of the drought (Weaver \& Albertson 1943).

During the least severe years of the period of great desiccation, this most drought resistant of all the mixed prairie grasses produced seedlings. But such 


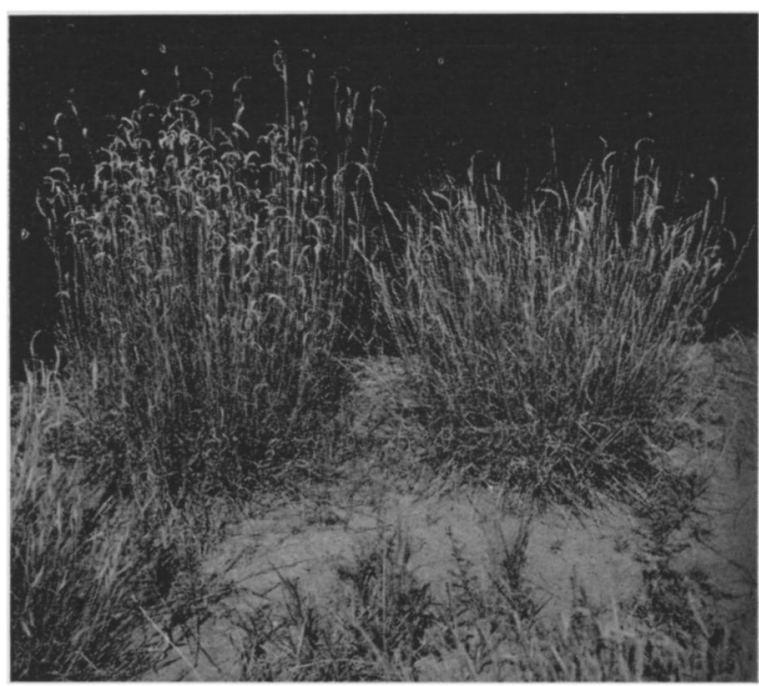

Fig. 116. Large bunches of blue grama that withstood the entire period of drought. They are elevated several inches above the surrounding eroded soil which was still bare in August, 1942. The bunches are 12 inches in diameter. From a range near Levant, Kan.

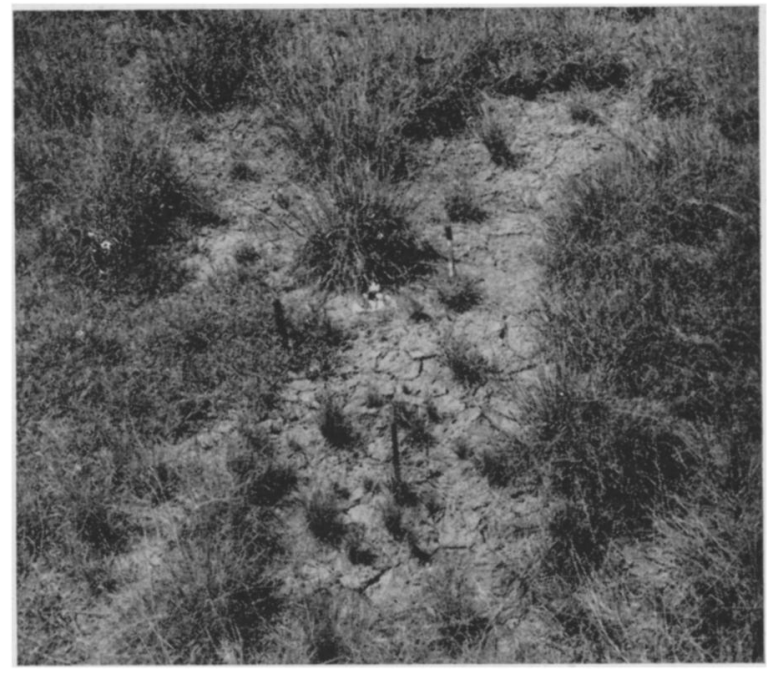

Fig. 117. Range near Sheridan Lake, Colo., showing old bunches of blue grama and numerous well established seedlings in 1943. Buffalo grass (left foreground) is spreading into the bare places by stolons.

gains as were made were largely lost in the extremely dry years, 1939-40. Thereafter seedlings were found in abundance almost everywhere, and their establishment was far more certain (Fig. 117). Thus, this stable species began slowly to return. Blue grama also spreads from rejuvenated tufts which result from the death of the central and often some peripheral portions of old bunches. The increase of blue grama and other grasses varied from season to season depending primarily upon amount of precipitation but also upon competition with weeds for light and water wherever they occurred (Fig. 118).

Where the cover of vegetation was dense, seed had

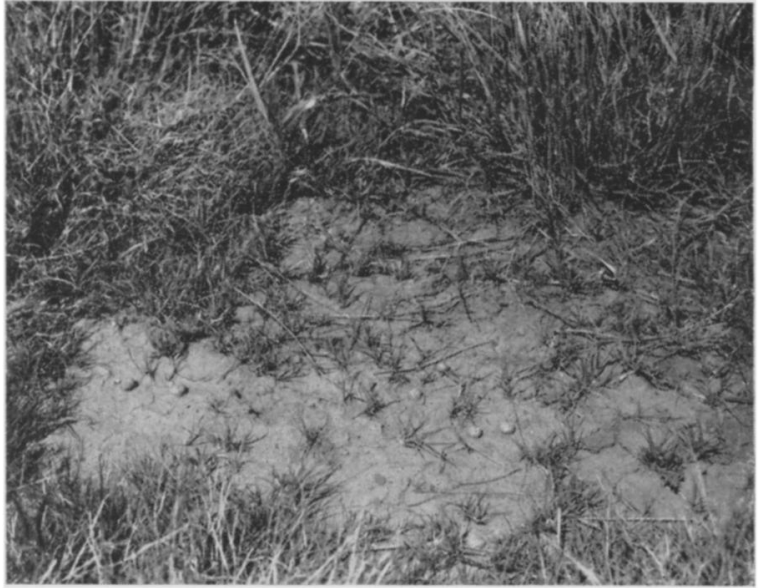

Fig. 118. Seedling grasses and stolons of buffalo grass becoming established between old bunches of short grass near Colby, Kan., in 1942.

difficulty in contacting the soil. In fact, it often did not reach the soil surface but instead was held above it. Moreover, growth of the seedling grasses was retarded by excessive shade. Tillering of blue grama and other established plants did not occur nor did the bunches spread where light was greatly reduced. The centers of large bunches sometimes died for lack of sufficient light where there was much shade from weeds and accumulated debris. Under such conditions stolons of buffalo grass also had difficulty or were unsuccessful in contacting the soil; nor did they grow well in deep shade. In many ranges in Kansas, the heavy growth of grasses and weeds in 1942 and their moderate utilization in grazing resulted in a somewhat reduced cover the next year. During this wet year blue grama reached a height of 12 to 18 inches and the foliage spread 4 to 8 inches beyond the periphery of the base of the clump. On favorable years where the short grasses were mixed in a good stand (as in 1942-43) and to a lesser extent when buffalo grass alone dominated, the shade was so dense that the seedlings, young tillers, and new stolons were reduced in amount as a result. This largely accounted for the bare spaces betwen the bunches of the new stand.

\section{Buchloe Dactyloides}

Buffalo grass was somewhat less drought resistant than blue grama and was also somewhat more easily smothered by dust. On rolling land, it showed a decided preference for lower slopes, depressions, and ravines; blue grama often dominating the steeper slopes except under intensive grazing. Blue grama was taller, and the foliage was denser. Thus, it held the wind-blown dust above the soil somewhat better than did buffalo grass, nor did the dust become compacted so readily about its base.

Despite these facts buffalo grass was sometimes found on ranges where there was no blue grama, and not infrequently it equalled blue grama in importance or was even more abundant at the end of the drought. 
While much buffalo grass remained in relict tufts and small patches, an abundant crop of seedlings was also produced on good years, especially after 1940 . The seed had been widely distributed over the surface of the soil and it was not quickly germinated by local showers. Several days with continuously moist surface soil-an infrequent occurrence during drought - are needed for germination.

But after good crops of seeds and abundant seedlings were common, as many as 11 seedlings of buffalo grass alone were counted on a single square foot in several Colorado ranges. The facts that this was late in August and that soil was well moist assured establishment and consequent pasture improvement. The spotted occurrence of buffalo grass in thousands of overgrazed ranges may be accounted for by a comomn method of seed dissemination. Cattle eat the foliage and seed hidden in it. The seed is not digested but deposited unharmed in a good substratum for growth. Seed of buffalo grass is also spread by rodents. Once the seedlings are established, spread by stolons is rapid.

Pastures in the northern half of western Kansas recovered more rapidly in 1941-42 than did many in Colorado, or those anywhere toward the dust bowl. In a large measure this was due to the greater amount and more uniform distribution of buffalo grass. Examples are numerous. Near Jennings, Kansas, where there was relatively little blue grama, the cover of buffalo grass in 1942 was rather uniformly 90 per cent or more. Near Colby, Kansas, buffalo grass increased fourfold in 1942. The resulting short grass cover was 90 per cent buffalo grass and 5 per cent blue grama. In fact, where a good cover was established in western Kansas, where most of the ranges were still greatly denuded by 1943, the major component was nearly always buffalo grass. Conversely, the blue grama pastures, where much less buffalo grass occurred, as about Limon, Last Chance, and Anton, Colorado, appeared in 1943 to have a much heavier cover than actually existed, because of the widely spreading foliage of the almost uniformly new stand of blue grama. But the interspaces consisted mostly of bare or poorly mulched soil.

When the dense mats of buffalo grass covered the soil, they soon became free of weeds and other grasses, except blue grama. The depth of ungrazed mats of short grasses should be emphasized. In 1943 ungrazed ranges had a more or less continuous cover of short grass 8 inches in depth with 3 inches of dead debris. When buffalo grass sod covered the soil about the bases of annual weeds they first became much dwarfed. The next season they were kept out because the seed either did not reach the soil or the soil was too dry or too much shaded for their growth. Near Broken Bow, Nebraska, plants of Leptilon canadense were 15 to 18 inches tall in openings in the short-grass sod, but only 7 to 10 inches high where the grass grew close to them. Elsewhere, much short grass was matted about last year's old stems but new ones had failed to develop. Vernonia baldwini, Verbena stricta, and Ambrosia psilostachya were always much smaller, fewer, or entirely absent in a dense sod. For example, in open soil plants of Verbena had 7 to 12 stems and were 40 inches tall. In an open sod there were 4 to 7 stems 27 inches in height, but in a new, closed, dense sod only 1 to 4 weak stems 18 inches in length were produced.

The intermingling of buffalo grass with blue grama has been studied with great interest. Alternating patches of the two grasses were often well established before this occurred (Figs. 119 and 120). At first the stolons spread between and among the bunches. This resulted in a denser sod. But since the established bunches of blue grama greatly overtopped the mats of buffalo grass, the cover appeared very irregular (Figs. 121 and 122). Later the buffalo grass grew very close to the bunches and even spread its stolons through them. As a result blue grama tillered less and lost in part its bunchy appearance. Its growth was also less rank because of in-

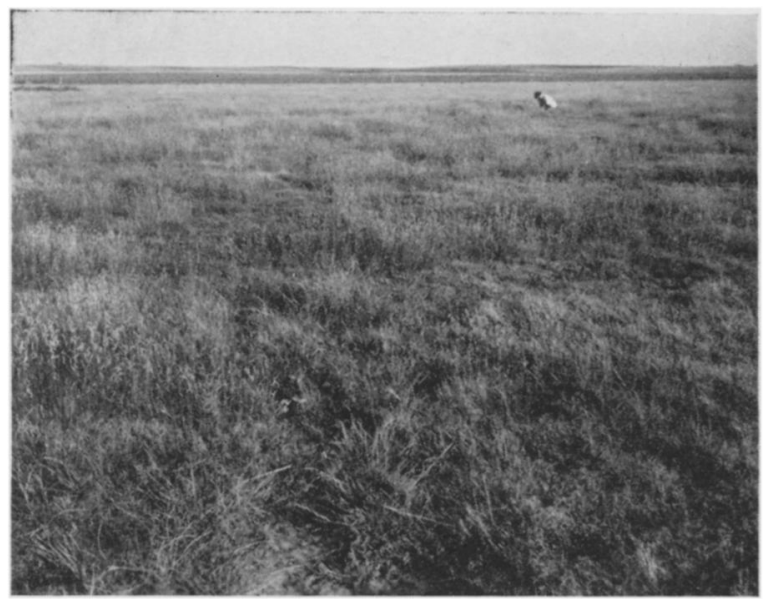

Fig. 119. Alternating patches of blue grama (taller), mostly with flower stalks, and low mats of buffalo grass in a range near Goodland, Kan. There was very little intermixing of the species by 1942 .

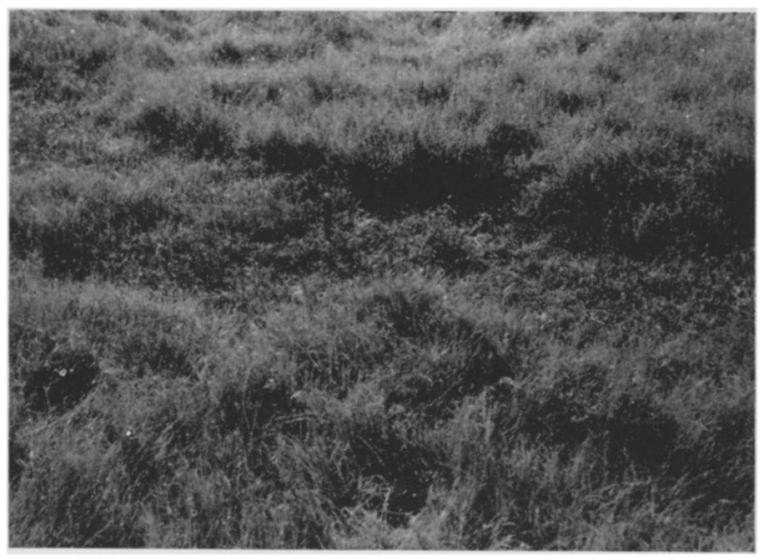

Fig. 120. Two lots of bunches of recovering but still open stands of blue grama and mat of buffalo grass that has filled the space between them. Thus far, July, 1943, there has been very little intermixing. Near Norton, Kan. 


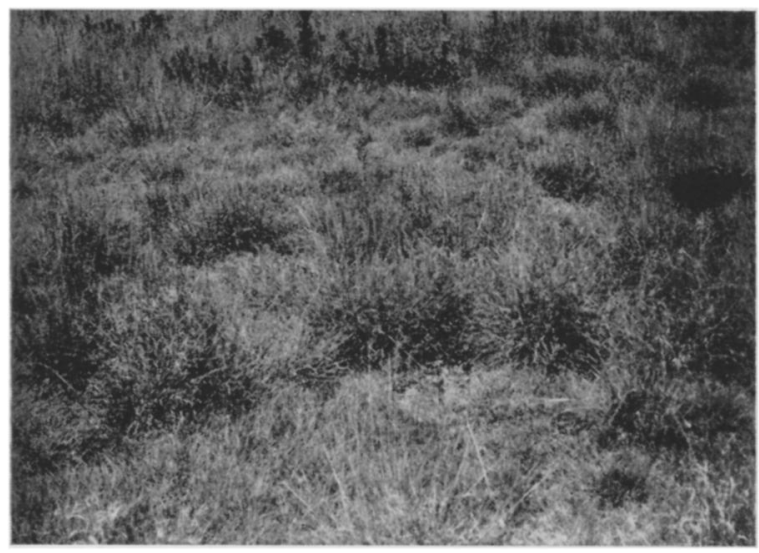

FIG. 121. Prairie near Phillipsburg, Kan., showing large relict bunches of blue grama with buffalo grass filling in closely around them. July, 1943.

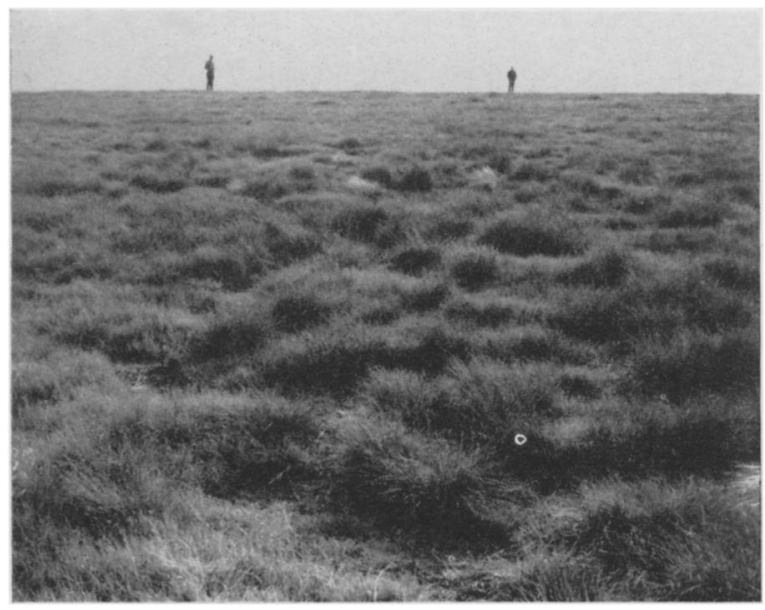

Fig. 122. The last stage of the subsere near Goodland, Kan. All the soil around the large bunches of blue grama has been occupied recently by buffalo grass, hence the irregular appearance of the cover.

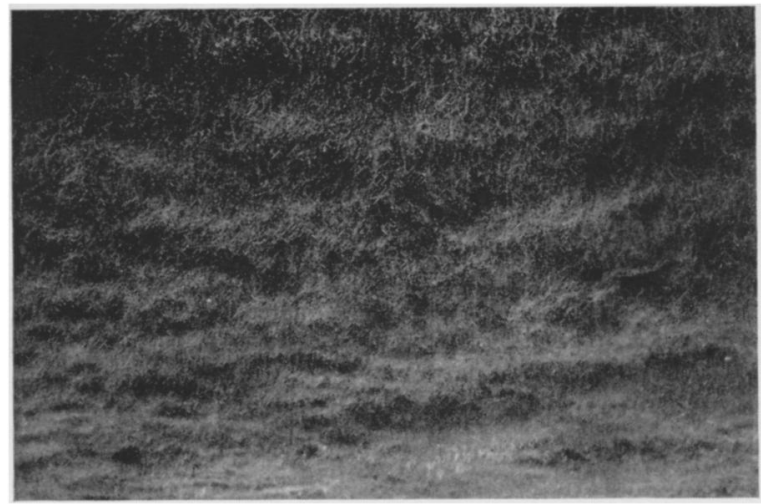

Fig. 123. Uniform cover, about 7 inches deep, of mixed short grasses under light grazing. This range near Phillipsburg, Kan., had always been well kept and although the cover was much opened by drought, it was repaired quickly and the grasses were well intermixed by August, 1942. The basal cover is 80 per cent and the ratio of blue grama to buffalo grass is about 1 to 4 . creased competition. Thus, the cover became much denser - often 95 per cent or more - and quite uniform in height, especially under grazing (Fig. 123). Other species were mostly excluded where the sod was densest, but openings permitted the usual scattered growth of wiregrasses, squirreltail, and sideoats grama.

The usual equal sharing of the basal area by the short grasses, which before drought appeared to be quite general over the area, now seldom occurred. But since blue grama is a more stable species than buffalo grass it will probably gradually increase its part in the mixture especially with recurrent drought. Indeed, the writers look forward to a somewhat equal mixing by adjustments under protection or moderate grazing because of the greater stability of blue grama, even without the occurrence of severe drought cycles.

Interrelations of the short grasses to cactus, especially the opuntias which form large clumps, are of interest and importance. During the years of desiceation when cactus increased so greatly, it furnished a haven for relict blue grama. It could not be grazed and consequently afforded oases for seed production. With the return of a more favorable environment for the enemies of cactus, their death began. This was in 1940, but their greatest destruction occurred in 1941-42. Since the more drought resistant blue grama was often the sole survivor in or near the place where the cactus had grown, the ratio of this species to buffalo grass was often higher in soil formerly occupied by the cactus. The new area for occupation was populated both by seedlings of blue grama and by the fragmentation of old crowns already established. The small bared areas were, for a time, partly occupied also by a dense cover of six-weeks fescue or other (usually small) annuals. Moreover, the abundant seedling cacti became established not in the normal mixed cover of the two short grasses, but after drought had usually killed most of the buffalo grass, but only thinned blue grama. Hence, the new clumps gave refuge only to blue grama for a long time. Also where relict bunches of cacti remained they increased their area by encroaching upon soil mostly free from buffalo grass. But sometimes one found places where buffalo grass alone had invaded the bared spots in the absence of blue grama. Buffalo grass, if present, later intermingled with the blue grama and then these irregular patches in the sod became smoothed out into the low, monotonous short grass cover and no trace of disturbance was evident.

A transition from buffalo grass to other grassland types occurred in buffalo wallows. These are shallow, normally wet depressions varying from a few square yards to several acres in area and scattered irregularly throughout the level or undulating plains. They are not to be confused with textural spots where the soils have, by silting, become highly impermeable to water. In these spots short grasses did poorly when they were submerged, often for weeks at a time, during and following heavy rains. But when summer drought came, the soil in drying shrunk and cracked deeply. This not only tore the roots but left 
deep openings, often an inch in width, and thus exposed the deeper soil to further drying. Hence, these spots always bore an open type of vegetation. Buffalo wallows were so wet before the drought that they were inhabited mostly by tall and mid grasses. Of these big bluestem, side-oats grama, wild rye, western wheat grass, and wiregrass were common. Because of the shade, buffalo grass grew but thinly in and around the edges of the wallow. But during the drought, it formed almost a continuous carpet with only remnants of the taller grasses and coarse forbs. With increased intensity and duration of drought, nearly all other species remained only as relicts, often only as dormant rhizomes or rooterowns in the soil. Thus freed from competition by drought (or by close grazing) the short grass completely controlled the area (Fig. 124).

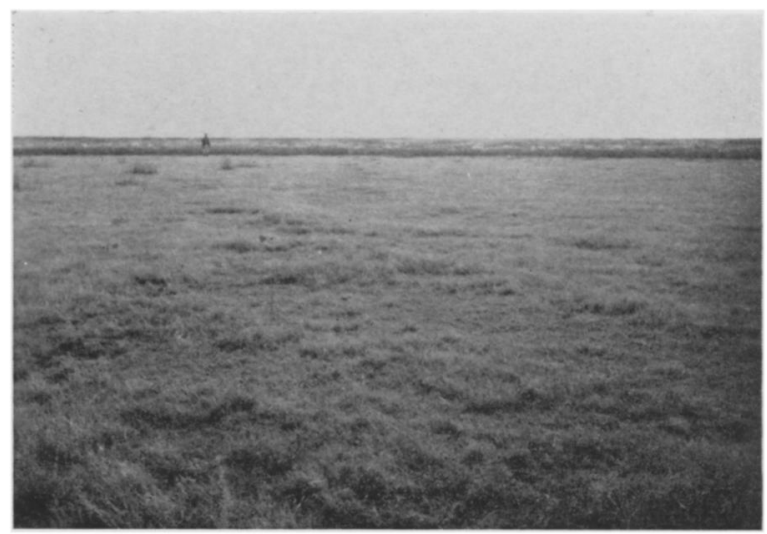

Fig. 124. An old buffalo wallow 2 miles east of Bird City, Kan., showing conditions in August, 1942. The bottom is covered with a continuous stand of pure buffalo grass. The patchy nature of the cover is due to irregular grazing. The view of this circular depression includes about two-thirds of its entire area. The wallow is entirely surrounded by a narrow zone of wheat grass (dark) growing on the banks which are 2 to 3 feet high; light-colored wire grass beyond.

\section{Bouteloua Curtipendula}

Side-oats grama, not yet discussed but occurring in the mixed prairie climax, was commonly found on steep slopes, eatsteps, and elsewhere on the midwestern range. It has been of rather small importance since the drought, except in the more easterly part and on rough land. But little occurred in the drier ranges near and in the dust bowl, and many miles have been traversed on the level uplands of Colorado without finding this grass, except in very favored places. But it was represented at least throughout the region and may return again in considerable amounts. It is drought resistant, a prolific seeder, and forms a distinct side-oats type on the "breaks" about streams (Fig. 125).

\section{RECOVERY OF POSTCLIMAX VEGETATION ${ }^{3}$}

In the big bluestem type on the lower slopes and in ravines where Andropogon furcatus was the chief

3 These data are mostly from Hays, Kansas, but they are representative of changes elsewhere.

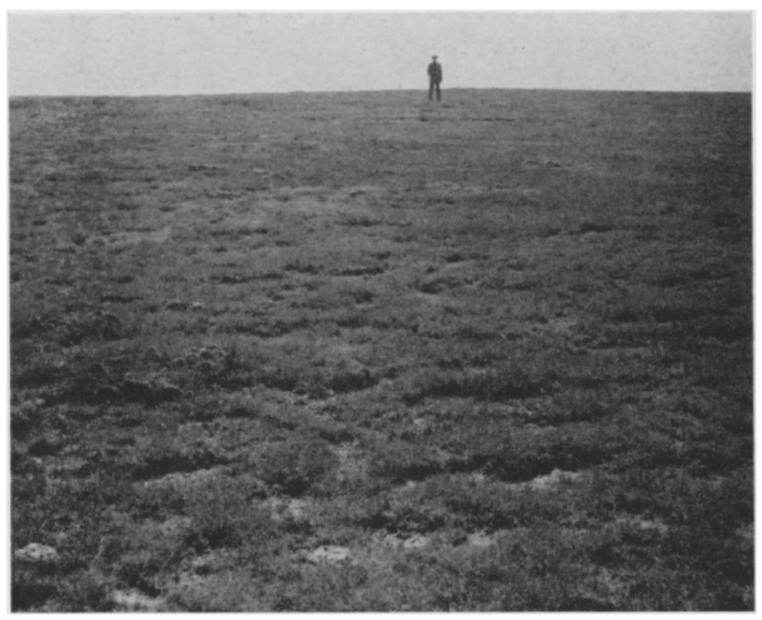

Fig. 125. Typical broken sod on a steep hillside near Last Chance, Colo. The slope is irregular and contains many small nearly level depressions into which the water infiltrates. Often they appear as miniature terraces. On this "catstep" type of land, of which there are many thousands of acres, side-oats grama is often common.

dominant, the total cover of grass was not significantly decreased by drought. It was merely changed in composition. Large areas of big bluestem were almost entirely replaced by western wheat grass, dropseed (Sporobolus asper hookeri), side-oats grama, and even by buffalo grass and blue grama. At the end of the drought the abundance of big bluestem was often only one-fifth normal (ef. Figs. 126 and 127).

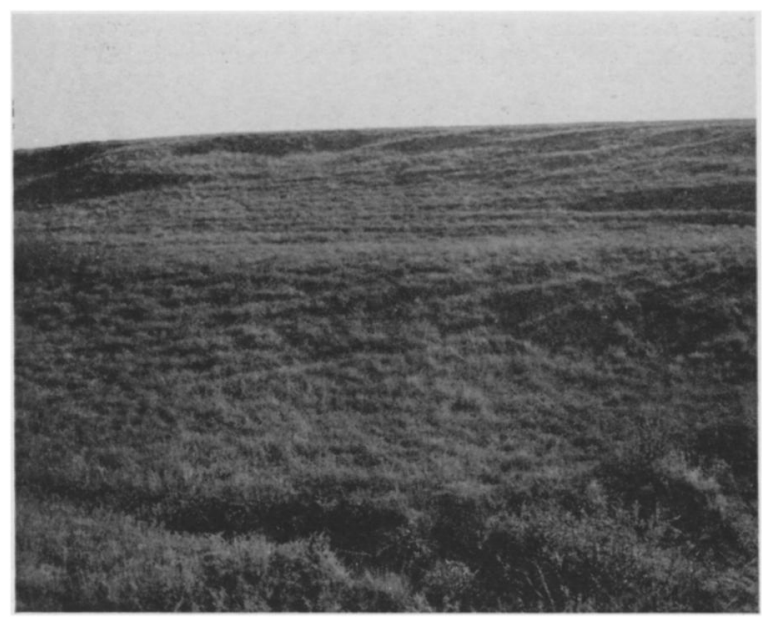

FIG. 126. Ungrazed postclimax range in bluestem type on northwest slope of a steep hill at McCook, Neb., in August, 1939. Chief grasses are Andropogon furoatus, A. scoparius, and Bouteloua curtipendula. Vegetation is typical of many similar north-facing slopes on hilly land.

That the sod had been opened in places was shown by the presence of weeds, even in ungrazed prairie, during the following years of good rainfall. In places Helianthus annuus, Chenopodium album, Leptilon canadense, Chamaesyce marginata, and Ambrosia tri- 
fida overtopped the grasses. Despite this fact, by 1943 the former predrought cover of grass had been nearly regained. Andropogon furcatus again composed 80 per cent of the vegetation, and small relict patches of Panicum virgatum were common. Sporobolus asper hookeri was much thinned, and Sorghastrum nutans was again frequent. It and big bluestem had returned almost entirely from renewed growth of dormant rhizomes. Both wheat grass and side-oats grama had been largely replaced by big bluestem, in fact only a little side-oats grama remained. The thicker cover had also shaded out all but remnants of the short grasses. Tall, coarse forbs such as Solidago mollis, Psoralea tenuiflora, Kuhnia glutinosa, and Salvia pitcheri were common.

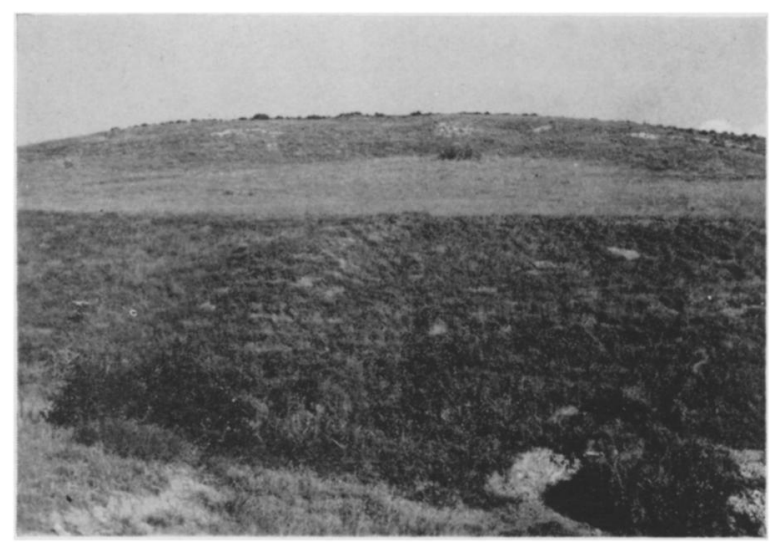

FIG. 127. Northwest slope in same area showing upper and lower belts of bluestems (dark) as in Figure 126. The level hilltop had been broken. The dark fringe at the edge of the field is Russian thistles. The light area on the gentle slope half way up the hill had been so thickly covered with dust, blown from the field, that the grasses were smothered. The light tone is due to a dense growth of lamb's quarters.

Ravines in pastures where this type prevailed were clothed, before drought, with Andropogon furcatus, Sorghastrum nutans, Panicum virgatum, Agropyron smithii, and Bouteloua curtipendula. Bouteloua gracilis and Buchloe dactyloides also occurred in small amounts, but they, like Agropyron smithii and in fact most of Bouteloua curtipendula, were largely limited to the more open places on the sides of the ravines. But with drought the cover of tall grasses became open and short grasses and wheat grass became abundant in it. Changes continued under persistant drought and grazing. By 1940 there was a good understory of short grasses overtopped mostly by western wheat grass and by small amounts of side-oats grama. But the normal or above normal precipitation permitted a return of the former grasses. The short grasses both decreased in amount and sideoats grama became much less abundant.

In the little bluestem type, Andropogon scoparius on the steep hillsides was greatly reduced, being replaced chiefly by side-oats grama and blue grama. At the end of the drought period, only occasional bunches of little bluestem could be found even on north-facing slopes or in depressions on the hillsides where runoff water accumulated. The reduction was from about 45 per cent of the vegetation to only 1 per cent.

After the good rains came, old crowns, apparently dead, began to show signs of life. From the periphery of some crowns a few feeble shoots developed. It then became clear that the extent of the loss was dependent upon competition for water by other plants as well as exposure to drought. In the open-bunch type common to knolls, losses were least. But on the hillsides where other grass had been abundant, losses were almost complete. By decay and in producing new shoots from the periphery, many of the old bluestem crowns lost their original form, several small bunches occupying the former position of the old one. Thus, the hillsides in 1943 were dotted with clumps of little bluestem. They were most abundant on the knolls (Fig. 128).

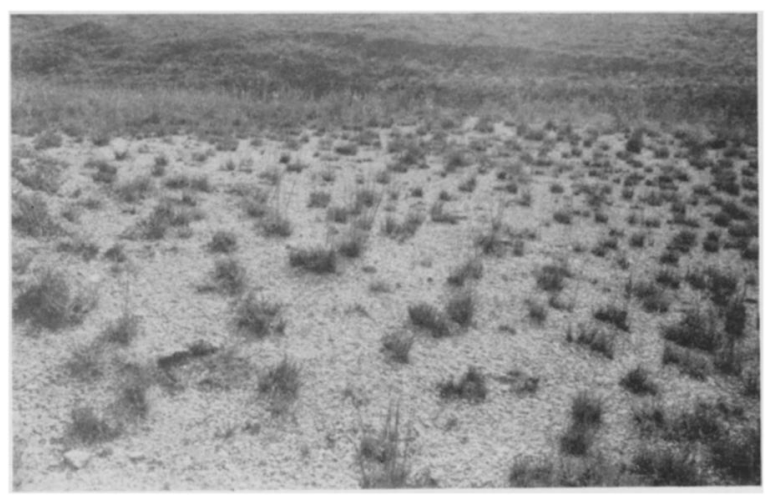

Fig. 128. Regeneration of little bluestem on rocky outcrops at Hays, Kan., September, 1943.

On the hillsides side-oats grama still retained first place among the grasses. It was intimately associated with the relict little bluestem. It appears clearly now that side-oats grama dominated this habitat during dry cycles but little bluestem during moist ones. In drought, both big bluestem and tall panic grass, which occurred throughout but were more abundant on lower slopes, became very inconspicuous and seemed to have disappeared. They did suffer heavy losses but returned slowly from long-dormant underground parts.

The more xeric portions of the hillsides formerly covered with the little bluestem type were now occupied by Bouteloua gracilis, B. hirsuta, and Sporobolus pilosus. They were reproducing rapidly by seedlings. Here wiregrass also occurred sparingly. On the upper side buffalo grass was invading. Patches 4 to 8 feet in width were scattered among the other grasses. It will probably continue to spread down the slopes until a closed cover of the taller species is developed. Then the buffalo grass will probably remain only as a relict in the dense shade and debris or wholly disappear. For side-oats grama was rapidly thickening its stand both by establishing new bunches from seedlings and from rhizomes, 2 to 3 
inches long, which radiated outward from the older bunches. Actually side-oats grama was very abundant about 1938 after the death of the two bluestems and tall panic grass. But after 1939 blue grama, hairy grama, and hairy dropseed spread widely after side-oats grama lost heavily. It seems probable should a moist cycle recur, that the bluestems will constitute the bulk of the postdrought vegetation, and thus complete an entire cycle of vegetative change.

\section{RECOVERY AS EXPRESSED IN YIELD}

Increase in dry weight is a good measure of growth and consequently of recovery of vegetation from drought as well. Stockmen, range examiners, and others were much interested in the relative productivity of the several types of vegetation during drought. To ascertain yields, barbed wire exclosures were placed on representative areas of each type-short grasses, little bluestem, and big bluestem-early in 1940, and 20 meter quadrats were staked out in each exclosure. These were all in the college pasture, an area of 750 acres just west of Hays, Kansas. Consequently they had been subjected to the same moderate degree of grazing. The vegetation was charted and clipped at a half-inch in height at the end of each year. The forage was divided into short grasses, mid and tall grasses, native forbs, and weeds. Yields were obtained not only during the last year of drought but also throughout the three years of recovery (Table 18).

TABLE 18. Average per cent basal cover and yield of vegetation in pounds per acre from different types of pastures at Hays, Kansas.

\begin{tabular}{|c|c|c|c|c|c|c|c|c|c|}
\hline $\begin{array}{c}\text { Grazing } \\
\text { type }\end{array}$ & $\stackrel{\varpi}{\varpi}$ & 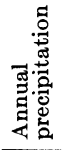 & 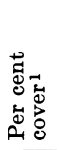 & 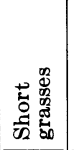 & 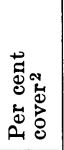 & 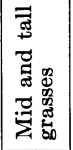 & 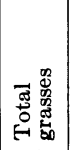 & 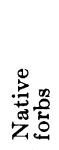 & 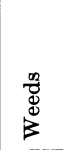 \\
\hline $\begin{array}{l}\text { Short grass } \\
\text { (moderately } \\
\text { grazed) }\end{array}$ & $\begin{array}{l}1940 \\
1941 \\
1942 \\
1943\end{array}$ & $\begin{array}{l}22.9 \\
28.1 \\
29.6 \\
16.2\end{array}$ & $\begin{array}{l}20 \\
43 \\
84 \\
85\end{array}$ & $\begin{array}{r}538 \\
890 \\
1,650 \\
672\end{array}$ & $\begin{array}{l}\ldots \\
0.2\end{array}$ & & $\begin{array}{r}538 \\
890 \\
1,650 \\
675\end{array}$ & $\begin{array}{c}0 \\
\ldots \ldots \\
\ldots \ldots \\
128\end{array}$ & $\begin{array}{r}433 \\
2,085 \\
1,400 \\
59\end{array}$ \\
\hline $\begin{array}{l}\text { Short grass } \\
\text { (overgrazed) }\end{array}$ & $\begin{array}{l}1940 \\
1941 \\
1942 \\
1943\end{array}$ & $\begin{array}{l}22.9 \\
28.1 \\
29.6 \\
16.2\end{array}$ & $\begin{array}{r}2 \\
22 \\
31 \\
30\end{array}$ & $\begin{array}{r}110 \\
1,092 \\
635 \\
458\end{array}$ & $\begin{array}{r}0.2 \\
14.5 \\
16.6 \\
17.0\end{array}$ & $\begin{array}{r}23 \\
1,455 \\
1,877 \\
23\end{array}$ & $\begin{array}{r}133 \\
2,547 \\
2,512 \\
481\end{array}$ & 30 & $\begin{array}{r}2,277 \\
597 \\
286 \\
1,039\end{array}$ \\
\hline $\begin{array}{l}\text { Little } \\
\text { bluestem }\end{array}$ & $\begin{array}{l}1940 \\
1941 \\
1942 \\
1943\end{array}$ & $\begin{array}{l}22.9 \\
28.1 \\
29.6 \\
16.2\end{array}$ & & $\begin{array}{c}\cdots \\
16\end{array}$ & $\begin{array}{r}9.5 \\
32.0 \\
38.0 \\
38.4\end{array}$ & $\begin{array}{l}915 \\
635 \\
824 \\
322\end{array}$ & $\begin{array}{l}915 \\
651 \\
824 \\
322\end{array}$ & $\begin{array}{r}121 \\
134 \\
97\end{array}$ & $\begin{array}{l}\ldots \ldots \\
\ldots \ldots \\
\ldots\end{array}$ \\
\hline $\begin{array}{l}\text { Big } \\
\text { bluestem }\end{array}$ & $\begin{array}{l}1940 \\
1941 \\
1942 \\
1943\end{array}$ & $\begin{array}{l}22.9 \\
28.1 \\
29.6 \\
16.2\end{array}$ & $\begin{array}{l}30 \\
82 \\
96 \\
91\end{array}$ & $\left|\begin{array}{l}1,638 \\
2,762 \\
3,896 \\
1,332\end{array}\right|$ & $\begin{array}{l}3.0 \\
2.7 \\
2.2 \\
1.6\end{array}$ & $\begin{array}{l}187 \\
675 \\
483 \\
339\end{array}$ & $\begin{array}{l}1,825 \\
3,437 \\
4,379 \\
1,671\end{array}$ & $\begin{array}{l}109 \\
140 \\
201 \\
298\end{array}$ & $\begin{array}{r}1,127 \\
1,448 \\
145 \\
65\end{array}$ \\
\hline
\end{tabular}

${ }^{1}$ Of short grasses. ${ }^{2} \mathrm{Of}$ mid grasses.

In the moderately grazed short-grass type, yields of both grasses and weeds were very low in 1940 . Yield of grasses increased considerably in 1941, but the grasses were undoubtedly greatly handicapped in growth by the ton of weeds (mostly little barley) produced during this year with open perennial cover but good precipitation. The next year the yield of short grasses was doubled but that of weeds much decreased. Precipitation was much lighter in 1943. Yield was reduced to only a little more than that in 1940, despite a basal cover of 85 per cent compared with 20 per cent three years earlier. This illustrates the fact that drought reduces yields first and basal area much later. Few weeds grew in the dense cover of perennial grass. The appearance of taller grasses (3 lbs.) and of forbs (128 lbs.) was evidence of the trend toward general recovery, despite low seasonal yields.

In the overgrazed short-grass pasture, which adjoined the large one, there was a greater proportion of buffalo grass than blue grama, and some relict taller grasses. Yield of perennial grasses, $133 \mathrm{lbs}$. per acre, was extremely low, but more than a ton of weeds, mostly little barley, was produced. A quick recovery the next year increased the yield of short grasses tenfold. The recovery of taller grasses was so great that the total yield was 1.27 tons per acre. Conversely, weeds were relatively few. The heavy yield of taller grasses in 1942 resulted in a great decrease in production of short ones. Total yield was about the same as the preceding year. Weeds were even further reduced. It is of interest that in the drier year of 1943 yield of the taller grasses was reduced almost 99 per cent, but yield of short grasses only 28 per cent. The inevitable increase of weeds with moderate drought is revealed in the half ton of them produced per acre.

The yield in the little bluestem type was nearly all from side-oats grama. This grass was greatly weakened by the 1939-40 drought and responded poorly to clipping. Despite a good increase in basal cover (from 9.5 to 32 per cent), the yield during the second year was low. It was only slightly greater ( 824 lbs. per acre) in 1942, and decreased to $322 \mathrm{lbs}$. during 1943. It well illustrates the harmful effect of removing the cover from a very open stand of vegetation even at the end of the growing season. Here the rocky, shallow soil common to this grassland type seems to be unfavorable to the growth of annual weeds. Only a small fraction of a pound was harvested on any year. The reappearance of native forbs is of interest.

The large amount of short grasses in the big bluestem type resulted from the opening of the cover by drought and its annual removal in clipping. The small yield of big bluestem and other taller grasses (187 lbs.) in 1940 is more of an index of their deep dormancy than their absence. Short grass yielded about three-fourths ton per acre and weeds about one-half ton of dry matter. In 1941 yield of taller grasses was much more, proportionately, than that of the shorter ones. Total yield of grass was about 1.75 tons per acre and weeds added another .73 ton, for they were mostly tall and had also profited by the increased water supply. Why yields of taller grasses decreased in 1942, unless due to close clipping, is not clear. The short grasses increased 29 
per cent over the preceding season's yield. Production of weeds greatly declined. By 1943 the taller grasses (although the yield was greatly reduced because of drought) had begun to shade the short grasses too much for their best growth. Their yield decreased to about one-third that of the preceding year. Yield of native forbs increased steadily year by year but ruderals had been nearly crowded out.

Summarizing, after two years of good rainfall, production of native grasses in the several types increased as follows: overgrazed short-grass type from 133 to 2,512 pounds per acre, or nineteenfold; and moderately grazed short-grass type from 538 to 1,650 pounds per acre, or threefold. Production in the little bluestem type decreased from 915 to 824 pounds per acre, a loss of 9.9 per cent; but it increased 2.4fold in the big bluestem type, where a yield of 1,825 pounds per acre was replaced by one of 4,379 pounds.

\section{RETURN OF FORBS}

A study of grassland always involves a consideration of forbs. They constitute an important part of prairie vegetation as was pointed out by Weaver and Albertson in 1943. Thornton (1936) states that: "It seems likely that the evolution and spread of nodulebearing legumes played a vital part in the geological history of the world in Tertiary times. Their spread and the consequent improvement in soil fertility and in the feeding value of the vegetation may well have contributed to the rapid evolution of mammals in the earlier Tertiary, while the herbaceous legumes in particular probably assisted the worldwide spread of grassland in the Miocene which resulted in the development of many of the modern groups of mammals."

During the great drought, the red false mallow (Malvastrum coccineum) was the only generally distributed, native, non-grassy species, aside from cactus, that increased in mixed prairie. It did this by vegetative propagation of underground parts when competition with the grasses was so greatly reduced. It thus increased in numbers manyfold. Its early growth in spring and its habit of semidormancy during drought enabled it to endure. A group of forbs which suffered great losses but were never completely exterminated included Psoralea tenuiflora, Sideranthus spinulosus, Lygodesmia juncea, Cirsium undulatum, $C$. ochrocentrum, Gaura coccinea, Solidago mollis, Kuhnia glutinosa, Allionia linearis, and Liatris punctata. But even these most xeric forbs became almost rare in 1939-40.

Following periods of good rainfall these forbs began to increase not only in numbers but in stature as well. With some this increase was from rhizomes; sometimes it was from seed from relict plants; but perhaps more frequently from seed that had lain dormant in the soil since the beginning of drought. The spread of Solidago mollis and Cirsium undulatum furnished representative examples of increase by rhizomes (Fig. 129). Conversely, old plants of Sideranthus spinulosus have been found surrounded by offspring from recently produced seed. In badly broken prairie cover, fifty to one hundred young seedlings were found within a radius of two feet from the parent plant. Psoralea tenuiflora served as the best example of increase from seed that had lain on or in the soil for seven or more years. This legume was greatly reduced in numbers early in drought even where the original cover was fairly well maintained. It rarely blossomed and probably never produced viable seed during the long dry period. Psoralea is returning only slowly.

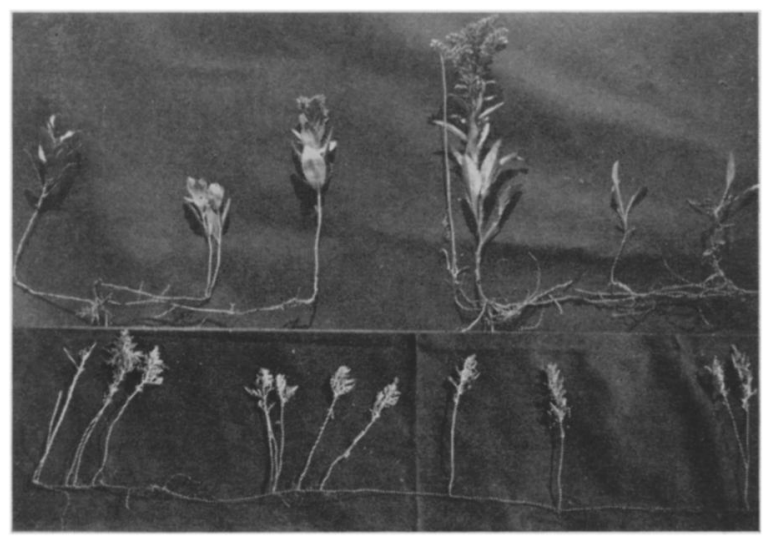

Fig. 129. (Upper) Underground stems and tops of Solidago mollis (left) and S. glaberrima (right). Both goldenrods decreased greatly during the dry cycle but are now reappearing, mostly from long-dormant rhizomes. (Lower) Stems of western ragweed (Ambrosia psilostachya) attached to a long rhizome.

Most of the native forbs in climax grassland were unable to withstand the extreme drought and consequently disappeared from the cover. Among these were Lepachys columnifera, Astragalus mollissimus, Specularia perfoliata, and S. leptocarpa, but there were many others. When the soil was again rather continuously moist at the end of the drought, myriads of seeds of these species, which had lain dormant for many years, germinated. Then the openings in the prairie sod were densely populated with the seedlings of many forbs. Foremost among them were Lepachys columnifera (Fig. 130). During the spring of both 1940 and 1941 as many as twelve seedlings were regularly found per square meter in places where it was formerly abundant. There is thus great irregularity and sporadic distribution of many forbs rather than their more general and sparser occurrence. This maintained even where the cover of grasses was nearly complete (Fig. 131).

Among the species which disappeared early was Gutierrezia sarothrae which because of its extreme abundance and unpalatable nature became a chief indicator of overgrazing and its concomitant evils. It entirely disappeared during drought. In fact,-it succumbed rather early and like most such species it returned promptly and often in great abundance (Fig. 132). Many forbs were first observed after drought on north hillsides, in depressions, and in other favorable refuges, from which they are now extending their range. 
Return of Ambrosia psilostachya has been confined largely to the eastern and more moist portion of mixed prairie. New plants came from seed and new stems from rhizomes. The plants were often scattered but were also frequently densely aggregated where numerous old rhizomes had remained alive (Fig. 133).

Distribution of the more important forbs of true and mixed prairie before the drought (since many ranged throughout) and their fate during the drought were shown schematically at the end of 1940 (Weaver $\&$ Albertson 1943). Recovery has not yet progressed far enough to complete this diagram, hence the chief

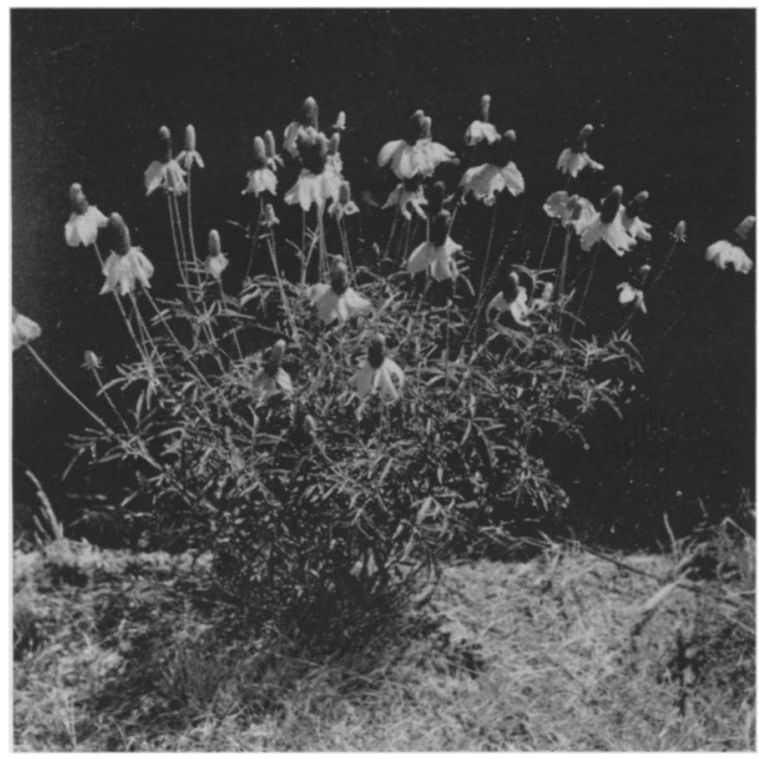

Fig. 130. A well developed coneflower (Lepachys columnifera) from a depleted short-grass range. This species was very conspicuous in many ranges in 1943, nearly all plants having originated from postdrought seedlings.

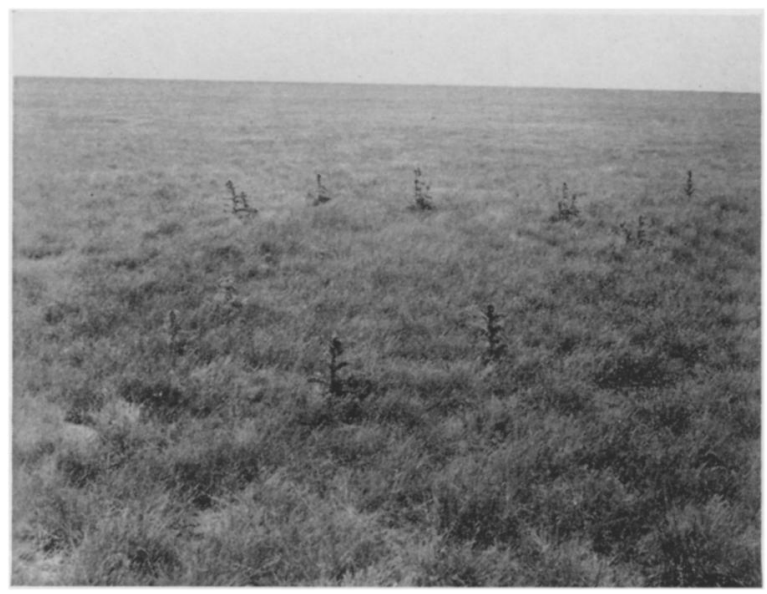

Fig. 131. Cirsium ochrocentrum in a large range near Anton, Colo. Note the good recovery of the short grasses (mostly blue grama) and the scarcity of forbs. Photo July, 1943. species are here grouped to indicate the degree of their recovery at the end of 1943.

\begin{tabular}{lc}
\multicolumn{1}{c}{ Marked Recovery } \\
Ambrosia psilostachya & Psoralea tenuiflora \\
Gutierrezia sarothrae & Sideranthus spinulosus \\
Lepachys columnifera & \\
\multicolumn{1}{c}{ Partial } & Recovery \\
Achillea occidentalis & Grindelia squarrosa \\
Allionia linearis & Hymenopappus corymbosus \\
Amorpha canescens & Kuhnia glutinosa \\
Anemone caroliniana & Liatris punctata \\
Asclepias pumila & Linum compactum \\
Astragalus crassicarpus & Meriolix serrulata \\
Astragalus missouriensis & Oxytropis lambertii \\
Astragalus mollissimus & Pentstemon albidus \\
Astragalus shortianus & Senecio plattensis \\
Cirsium ochrocentrum & Sophora sericea \\
Cirsium undulatum & Solidago glaberrima \\
Delphinium virescens & Solidago mollis \\
Erigeron ramosus & Thelesperma gracile \\
Gaura coccinea & \\
& \\
Allium nuttallii & Nocovery \\
A ntennaria campestris & Lygodesmia juncea \\
Aster multiflorus & Parosela enneandra \\
Cheirinia aspera & Phellopterus montanus \\
Galpinsia lavandulaefolia & Psoralea cuspidata \\
Lithospermum linearifolium & Psoralea esculenta \\
& Stenosiphon linifolius
\end{tabular}

With the return of more mesic conditions and a much extended cover of grasses, Malvastrum coccineum decreased in numbers and regained more nearly its predrought abundance.

Cactus constitutes a definite portion of the vegetation of mixed prairie. It was represented principally by various species of Opuntia, and was generally most abundant on level or rolling land with clay loams or other heavy types of soil. Cactus increased greatly in abundance during the long cycle of drought, but decreased in a remarkable degree during the four years with more than normal precipitation (Fig. 134) (Costello 1941). Its increase during drought was attributed primarily to little or no competition with a greatly depleted plant cover but also to the aridity of the atmosphere which was unfavorable to the development of insects which tend to destroy it. Especially damaging were the larvae of a moth (Melitara dentata) which consumed the pulp inside the stems (Cook 1942).

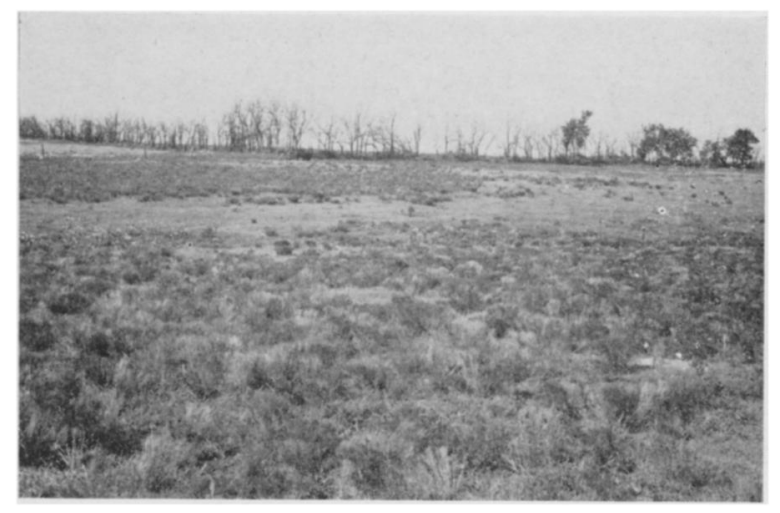

FIg. 132. Return of Gutierrezia sarothrae from seed stored in or on the soil of an overgrazed range near Rush Center, Kan., in August, 1943. The osage orange (Maclura pomifera) in background had suffered a loss of 98 per cent. 


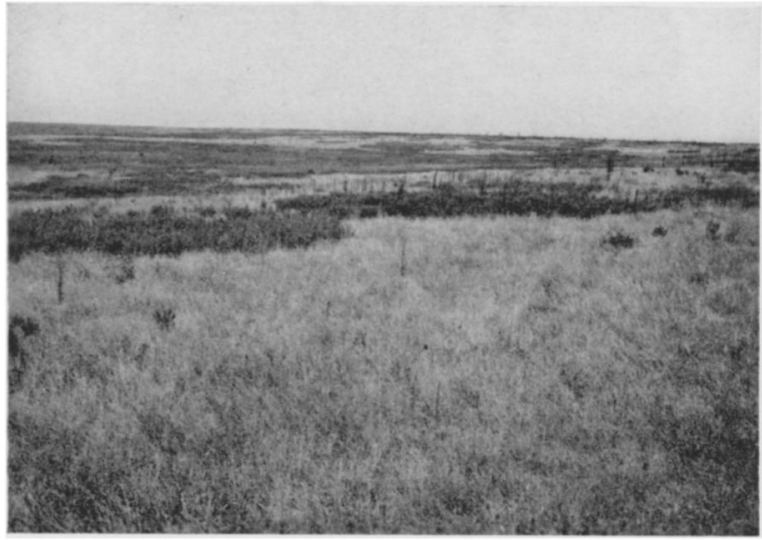

Fig. 133. College pasture near Hays, Kan., with short grasses and (dark) patehes of western ragweed ( $\mathrm{Am}$ brosia psilostachya). August, 1942. This weed disappeared completely during drought but returned promptly and in abundance from dormant rhizomes.
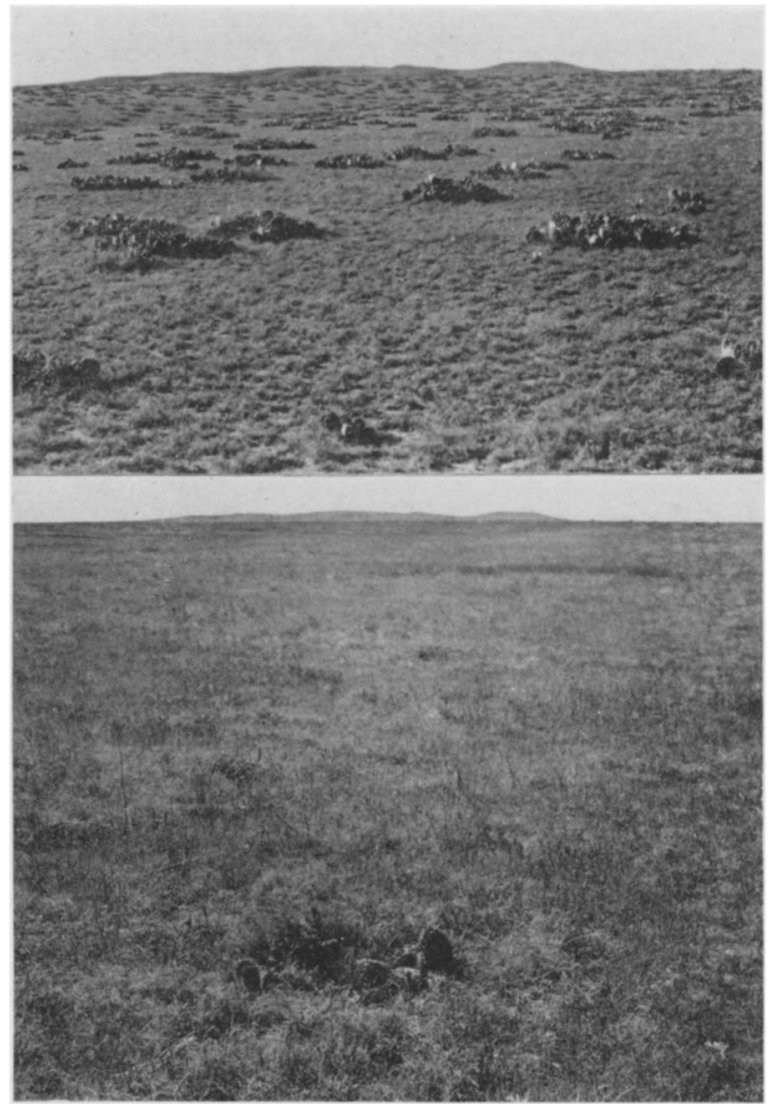

Fig. 134. (Upper) Pasture near Ellis, Kan., in July 1939, showing abundance of cactus in overgrazed short grass. (Lower) Same view late in May, 1943. Insects have killed practically all of the eactus; only small fragments remain.

Opuntia humifusa and $O$. macrorrhiza were the dominant species in prairies of western Kansas; $O$. polyacantha was most abundant on the plains of eastern Colorado. The transition from abundance of one species to the other, of course, is gradual. All but the last depend almost entirely upon seed for propagation. Seed is often carried by rabbits and rodents. When green foliage is scarce, rabbits feed upon the succulent fruits containing the mature seed. These pass unharmed through the digestive tract and are frequently deposited at considerable distances from the parent plant. Sometimes rodents bury large quantities of cactus seed, some of which may never be eaten but may germinate under favorable conditions of moisture and temperature (Timmons \& Wenger 1940). Moreover, it is not uncommon for branches of cactus to be broken from the plant and carried for a distance on the hoofs of cattle. The pieces readily produce roots when in close contact with moist soil. In this way new plants are produced vegetatively.

Opuntia polyacantha propagates widely by rootsprouts (Harvey 1936). Numerous plants were often found originating in this manner (Fig. 135). These small plants develop rapidly and in only a few years produce a large clump one or more feet in diameter. Sometimes several plants coalesce to form an enormous clump 8 to 12 feet in diameter. Some have been found which formed a continuous mat of branches for a distance of 30 feet.

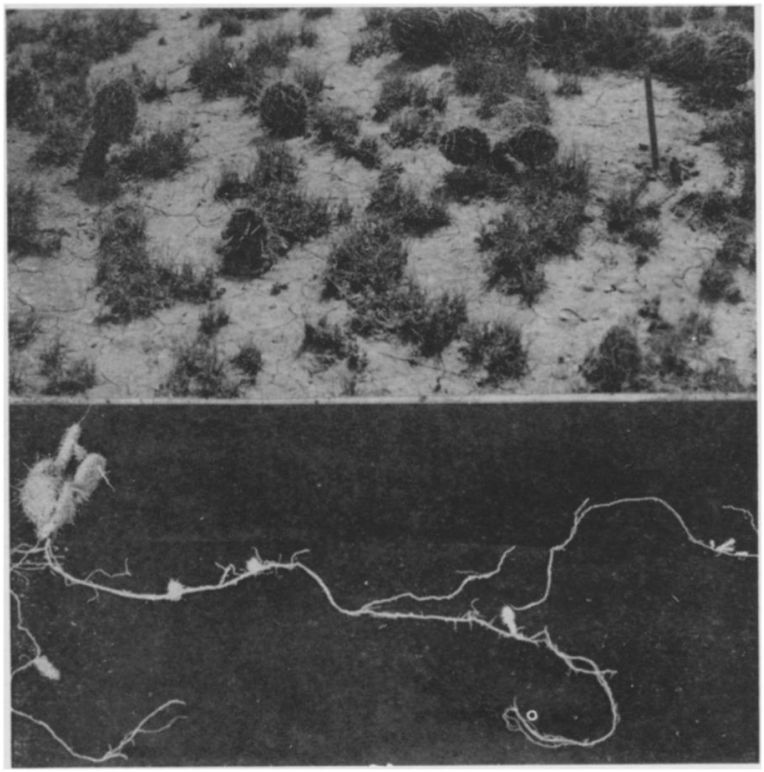

Fig. 135. (Upper) Young plants of Opuntia polyacantha arising from roots of parent plant. (Lower) Roots of this Opuntia showing numerous young stems.

Increase in number and size of plants continued from 1933 until 1940. The plants were often so dense that not only were some ranges entirely worthless for grazing, but even jackrabbits avoided them. Cactus sometimes grew so thickly that it was impossible for livestock to lie down on the range without coming in contact with this spiny plant (Costello 1941, Turner \& Costello 1942).

A significant ecological relationship existed between cactus and other native prairie species, both plant 
and animal. Many ranges, almost devoid of native species otherwise, contained abundant clumps of cactus and well developed native grasses growing in or protected by the clumps but extending above them. These relict grasses produced seed during periods of favorable soil moisture. The cactus harbored various kinds of prairie rodents.

Increased soil moisture at the close of the drought was conducive to a dense growth of vegetation. This competed with the cactus for soil water and light and also by transpiration increased the humidity. With increased precipitation it also furnished a favorable environment for insects injurious to the cactus. Vast numbers of these plants were found greatly injured or dead as a result of insect attacks (Fig. 136). Their place was soon taken by the grass. Usually, however, relict cacti remained, but the general population was greatly reduced, somewhat to the proportions in which it occurred before the dry cycle.

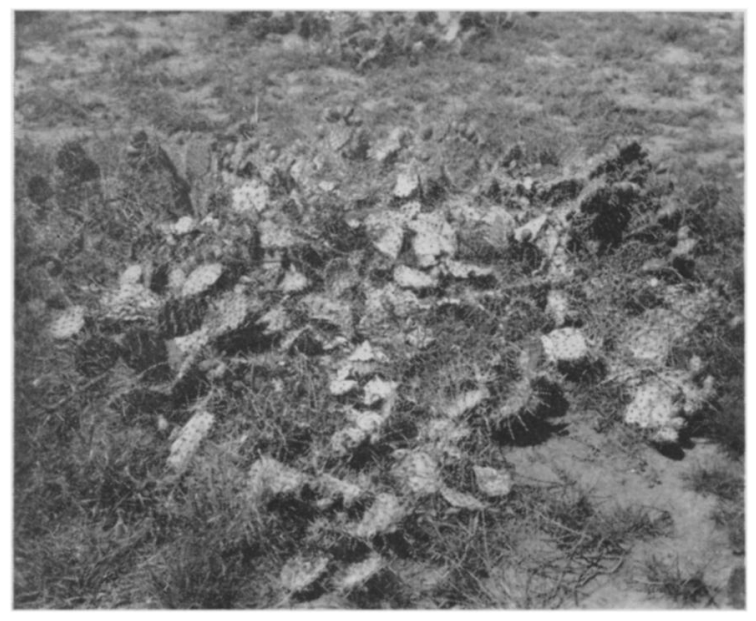

FIG. 136. A cactus (Opuntia macrorrhiza) that is dy. ing as a result of insect attack. Meade, Kan., August, 1939 .

The present lack of abundance of forbs both in species and numbers may be illustrated by the results of field investigation in two sections of the area. On a week's field trip in 1943 from Phillipsburg, Kansas, to Limon, Colorado, but including much adjacent territory, all species found in 19 ranges were listed and each was given its ranking in each range. The ratings were (1) very abundant, (2) abundant, (3) common, (4) infrequent, and (5) rare. The average number of species of perennial native forbs (including eactus) per range was 16 . The smallest number of species was 5 ; no range had more than 28 . Only 5 per cent were very abundant. They were Malvastrum coccineum at 11 stations, Opuntia spp. at 2, and three other species at a single station each. Four per cent ranked as abundant, but each of the 7 species concerned was abundant at only one or two stations, rarely three (Psoralea tenuiflora and Gaura coccinea). Another 11 per cent ranked as common, 20 per cent as infrequent, and 60 per cent as rare.
Thus, four-fifths of the forb population was still infrequent or rare. But compared with the census in 1939-40, forbs showed an excellent recovery.

On a second trip in August, 1943, the forbs in 25 ranges in west-central and southwestern Kansas and adjacent Colorado were studied. An average of only 8 species of native perennial forbs per station was found. The highest number per range was 11 to 16 (in seven ranges), but only 2 to 4 species were found in each of eight others. Only 13 per cent of the total rankings were (1) very abundant. Here again Malvastrum coccineum was highest and Opuntia humifusa next; the other high ranking was once only for each of 12 species. Six per cent of the entries were in class 2, 20 in class 3,13 per cent were infrequent, and 48 rare. Thus, the forb population was even lower than northward and northwestward, and only the most drought resistant species or those of recent recovery were ever very abundant. But even here the student with a knowledge of previous conditions could note marked improvement.

\section{SUMMARY}

Recovery of vegetation of midwestern grasslands from the great drought (1933-40) has been studied during three years of sufficiently increased precipitation (1941-43) to promote the development of a good cover.

The area includes the true prairie in southwestern Iowa, southern Nebraska, and northern Kansas, and the mixed prairie, with its short-grass disclimax, in southwestern Nebraska, western Kansas, and eastern Colorado. The investigation is a continuation of the study of 30 large typical prairies begun before the drought. It has now been extended over the region generally.

Abnormally high precipitation wet the dry soil in 1941-42 to a depth of 5 to 6 feet. A soil moisture reserve promoted fair to good growth in 1943, except in the southwest, despite summer deficiency in rainfall.

Water content of soil at Hays, Kansas, and Lincoln, Nebraska, is recorded week by week for the years 1939 to 1943, inclusive. Data are also given for 2 other stations in true prairie and 2 in mixed prairie.

Evaporation at Lincoln from a free water surface in 1942-43 was 13.6 and 10.4 inches lower than during 1939, when 53.8 inches of water were lost during the 6 summer months. Similar decreases at Hays were 13.2 and 15 inches below the average for 7 years of drought.

Wind movement decreased greatly during the period of recovery. Dust storms were less frequent, more local, and much less severe. Temperatures were lower following drought.

In true prairie, which is summarized first, rainfall in summer, 1934, was extremely low, soil moisture became unavailable to 4 feet in depth, and a terrific heat wave occurred. In 1935 it was found that losses of the plant cover west of the Missouri River were heavy, and increased southwestward to 80-90 per cent. 
Certain native forbs spread rapidly and widely and persisted in enormous abundance for several years. Many ruderals became widely and thickly distributed.

In 1935 six-weeks fescue (Festuca octoflora), blue grama (Bouteloua gracilis), and especially western wheatgrass (Agropyron smithii) increased greatly. Severe drought in 1936-37 resulted in great advantage to these grasses and buffalo grass (Buchloe dactyloides), since they thrived while their competitors waned.

Approximately normal precipitation in 1938 resulted in an excellent development of vegetation and the production of much seed. Wheat grass, blue grama, and buffalo grass continued their spread. Big bluestem (Andropogon furcatus), needle grass (Stipa spartea), and prairie dropseed (Sporobolus heterolepis) thickened their relict stands and increased greatly.

Spring rainfall in 1939 and 1940 was followed by severe summer drought. Wheat grass waned in 1939 in competition with an enormous stand of side-oats grama (Bouteloua curtipendula). Short grasses increased; most other vegetation suffered from severe desiccation. Great losses of prairie relicts and sideoats grama occurred in 1940 , but wheat grass and short grasses took possession of entire prairies. They often intermingled and formed mixed prairie.

Chief components of the subsere, aside from relict perennial grasses, were early annuals, long-lived native forbs, and ruderal forbs and grasses. Great alternes of closely seeded six-weeks fescue furnished protection to the soil throughout the drought. Chess (Bromus secalinus) and little barley (Hordeum pusillum) were also very abundant. Many-flowered aster (Aster multiflorus) developed a dense cover over hundreds of acres; it disappeared quickly before invading wheat grass but more slowly among other perennial grasses. Smooth goldenrod (Solidago glaberrima) became a weed sometimes as widely spread as aster. Daisy fleabane (Erigeron ramosus) increased so greatly in so many prairies that it was a chief soil stabilizer throughout the drought.

Chief among ruderal forbs was peppergrass ( $L e$ pidium densiflorum) which spread like a scourge in 1936-37 but almost vanished in 1938. Pursh's plantain (Plantago purshii) and horseweed (Leptilon canadense) occurred abundantly in certain prairies, and lamb's quarters (Chenopodium album), Russian thistle (Salsola pestifer), and rough pigweed ( $\mathrm{Am}$ aranthus retroflexus) often demarked rich, loose soil.

When the weedy native forbs had been suppressed by the increasing population of grasses, when the annual grasses and weeds had been mostly replaced by perennial grasses, and when the dominant speeies had replaced the former interstitial perennials, several very definite communities crystallized out of the heterogeneous drought populations.

The needle grass type was reestablished from stands of this species which were greatly thinned early in the drought. It regained its original territory and spread very widely into drought-opened adjacent soil.
Prairie dropseed, of minor importance in predrought years, recovered from extensive early losses and extended the area of its communities greatly.

Western wheat grass spread by seed and appeared over a wide territory immediately following 1934; invasion was well advanced by 1938 . It was favored by moist springs and dry summers, but often utilized all available moisture and thus caused dwarfing or death of most other vegetation. Relict bluestems were usually replaced by pure stands of wheat grass.

Clipping experiments have shown that change from big bluestem to wheat grass is accompanied by a decrease in yield of nearly one-half on upland and two-thirds on low ground.

Blue grama often survived where all other grasses died. It spread almost without interruption from 1935 to 1942 , and promptly thickened its stands. Buffalo grass, less abundant and more greatly harmed by drought than blue grama, increased greatly.

A mixed prairie type was formed by the replacement of bluestems by western wheat grass and short grasses and the later intermingling of mid grass and short grasses. This began in 1938 and was completed in 1941. Invasion had ceased, since the remaining area was occupied by other vegetation, but not the intermixing of short grasses and wheat grass.

The big bluestem type on upland resulted from the survival of this grass wherever the former little bluestem type had lost its chief component, Andropogon scoparius. After heavy initial losses, big bluestem survived the drought in the bunch habit, but later, unless overwhelmed by wheat grass, spread to form a sod. Its stands on lowland were often greatly thinned, but it usually replaced its losses and reestablished the tall-grass type.

A relict big bluestem-little bluestem type resulted from modification of the predrought little bluestem consociation, but it covered relatively small areas. Usually much little bluestem had died and its place was taken by big bluestem. Some survived as dormant rooterowns.

Mixed grasses formed a community of variable composition over considerable areas where widely scattered plants of different species recovered, reseeded, or invaded at about the same time. Also, big bluestem spread widely or renewed growth from dormant rhizomes and formed mixtures with various other grasses. These species have merely completed the occupation of bared soil where no other types had gained control. The community is not climax.

The present mosaic of grassland patterns is merely one phase of a long developmental process. In order of size of area occupied, the types in 1943 were mixed prairie, western wheat grass, big bluestem, needle grass, blue grama, prairie dropseed, relict big bluestem-little bluestem, and mixed grasses.

Side-oats grama, June grass (Koeleria cristata), and several other grasses which were predrought interstitials became important seral dominants. Some were temporarily so abundant as to threaten the dominance of wheat grass and big bluestem, but all have again been reduced in amount. 
Recovery was repeatedly delayed by losses on driest years offsetting gains made during the less dry ones. Methods of recovery of grasses were increase in size of relicts by tillering, production of rhizomes and stolons, breaking of dormancy in old rooterowns and underground parts, and production of abundant seedlings. Breaking of dormancy occurred in some prairies after a single year of good rainfall and in nearly all in 1942-43. Little bluestem usually survived in a dormant state only in restricted places but for 5 to 7 years. Big bluestem revived from dormancy even where wheat grass or blue grama had invaded and grown for several years.

Seeds of western wheat grass, needle grass, blue grama, and a few other grasses produced seedlings that became established during years of less severe drought. Little bluestem and big bluestem produced no seed or seedlings or seeded only rarely until 1941. Seedlings were abundant in bare places in 1942-43, and plants only 2 to 3 years old were common in 1943.

Recovery was expressed by increase in numbers, vigor, and stature of plants, and by the resultant thickening of the stand and the exclusion of ruderals. It was also shown by reappearance of societies of forbs, reconstruction of a layered vegetation, accumulation of debris, and increased yield.

Forb populations were not replaced during drought. Seedlings were rare until 1941-42. Many species grew, sometimes thickly, after a year or two of good precipitation from seeds that had been dormant 7 years. Others came from long-dormant rootcrowns, rhizomes, or roots.

Postclimax vegetation developed remarkably following drought. In ravines where big bluestem, Indian grass (Sorghastrum nutans), and tall panic grass (Panicum virgatum) apparently had been replaced by wheat grass, they not infrequently reappeared from rhizomes. In an experimental area big bluestem was suppressed by a thick growth of slough grass (Spartina pectinata) in 1943 which grew from dormant rhizomes.

Yields on upland increased from 0.79 ton per acre in 1940 to 1.85 tons in 1941 . Yield in 1943 was 2.15 tons.

Recovery in mixed prairie, where most of the area is range land, was delayed by overgrazing in some places and by understocking in others, but usually it was prompt. Major features of recovery were closely connected with the development of buffalo grass, blue grama, and sand dropseed (Sporobolus cryptandrus). Buffalo grass entirely disappeared from some ranges and in many remained alive only in the best watered places. But others retained small tufts or occasional patches. Blue grama was never killed so uniformly nor so completely over a wide area. Unless deeply buried by dust, some bunches nearly always remained. Sand dropseed was widely spread but it was sparse before the drought; it increased greatly during late drought and thereafter.

Rate of recovery varied widely depending upon kind of predrought cover, degree of depletion, and kind of grass relicts at the end of drought. Other factors were amount of damage from burial by dust, intensity of grazing and trampling during recovery, and amount and distribution of local precipitation. Recovery was always slower where blue grama alone remained than where buffalo grass was intermixed with it or was the sole survivor.

Increase in cover and change in its composition during recovery (1940-43) have been ascertained in ranges near Hays by means of chart quadrats. In wholly ungrazed ranges, with cattle excluded after 1932, blue grama increased from 10 per cent to 22 , but buffalo grass from 9 to 66 . Under moderate grazing blue grama increased from 18 per cent to 22 and buffalo grass from 8 to 53 . In an overgrazed range increases in the same sequence were 7 to 15 and 6 to 78 per cent. Such enormous gains sometimes occurred at the expense of blue grama.

An ungrazed cover of 89 per cent in the shortgrass type in 1932 was reduced to 20 per cent by 1940 , but it was 90 per cent after 3 years of recovery. An overgrazed range with 80 per cent cover was reduced to one of 3 per cent, but owing to the wonderful recuperative powers of buffalo grass the cover was increased to about 93 per cent by 1943 .

Ungrazed little bluestem type in thinner soil on rough land with a normal predrought basal cover of 60 per cent decreased to about 16 . But it was 46 per cent in 1942-43. Little bluestem was entirely replaced by side-oats grama, blue grama, and buffalo grass.

Study of percentage composition showed that the predrought sod of about equal amounts of buffalo grass and blue grama was replaced after drought by one with two-thirds buffalo grass and one-third blue grama. But in thinner, drier soil with an equal predrought mixture, the more xeric blue grama finally composed about three-fourths of the cover. Where little bluestem formed 45 per cent of the cover and side-oats grama 17 before the drought, the postdrought cover contained 3 per cent little bluestem, 66 side-oats grama, and 21 per cent short grasses. Big bluestem nearly regained its 76 per cent of cover in its type, after being reduced to 15 , with proportional decreases in invading wheat grass and short grasses.

Studies at 15 stations in west central Kansas (1940-43) revealed that the initial average basal cover under (1) light dusting and moderate grazing, (2) light dusting and overgrazing, (3) heavy dusting and moderate grazing, and (4) heavy dusting and overgrazing, was $2.7,9.9,5.5$, and 1.8 per cent, respectively, in 1940. It increased in the same order by 1943 to $75.5,68.6,62.1$, and 26.1 per cent.

Succession on badly or completely denuded ranges consisted of four stages. The first weed stage was composed chiefly of a dozen annual forbs, among which were Russian thistle, lamb's quarters, narrowleaved goosefoot (Chenopodium leptophyllum), common sunflower (Helianthus annuus), monolepis (Monolepis nuttalliana), and horseweed. They oc- 
curred wherever the soil had been laid bare by drought or wind erosion or deposit; complete destruction was widespread, especially in the southwest. They played an important role in temporarily stabilizing the soil.

A second weed stage consisted of little barley, sixweeks fescue, peppergrass, species of plantain and stickseed (Cryptantha), and other species which usually dominated more stable soil than the preceding one. These early maturing plants formed either a discontinuous patchy layer above the grasses or overshadowed them entirely throughout the range.

An early native grass stage consisted of sand dropseed, western wheat grass, tumblegrass (Schedonnardus paniculatus), false buffalo grass (Munroa squarrosa), and windmill grass (Chloris verticillata). By 1940 sand dropseed was the most widely spread and most abundant. Thickness of stand was somewhat proportional to the degree of destruction of the short grasses. The sand dropseed type became common. Wheat grass was represented widely but often sparingly except in depressions or on rolling land.

The late grass stage, consisting chiefly of short grasses but with wiregrasses (Aristida), side-oats grama, and squirreltail (Sitanion hystrix), was the same in both subseres.

Succession in ranges reduced to one-fourth or more of a normal cover but with sufficient perennial grasses to regenerate quickly had only a single weed stage. Seral dominants were nearly the same as those in the preceding second weed stage but included Russian thistle and horseweed.

Development of the late grass stage in both subseres was primarily the return or increase of blue grama and buffalo grass.

These grasses are now, as before the drought, the most abundant grasses of the midwestern ranges. Mid grasses, scattered throughout before drought, nearly disappeared. With rare exceptions, they are only beginning to reappear.

Relict blue grama, often covering only 1 to 5 per cent of the soil, increased slowly during the less severe drought years and rapidly after 1940. Development of both seedlings and tillers was often retarded by too great a reduction of light caused by dense stands of weeds. Where drought was most severe, often nearly pure stands of blue grama developed.

Buffalo grass is somewhat less drought resistant than blue grama, and was more easily smothered by dust. Where it remained in relict bunches and small patches, an abundance of seed was produced on the more favorable years, especially after 1940. Where tufts or seedlings were widely distributed recovery was much more rapid than that of blue grama and resulted in a great preponderance of buffalo grass in the new cover.

Intermingling of the two short grasses and the formation of a dense, uniform cover are described, as are also the interrelations of short grass to cactus.

Cover in postclimax vegetation dominated by big bluestem was greatly thinned by drought and dor- mancy of the tall grasses. The area was invaded by coarse weeds; certain mid grasses increased greatly and even short grasses invaded. After drought these were largely replaced by big bluestem.

Little bluestem which dominated on steep hillsides was reduced from about 45 to 1 per cent, its place being taken during drought by side-oats grama and blue grama. It is returning slowly.

Recovery from drought was clearly expressed in increased yield. Production in the big bluestem type in 1942 was 2.4 times as great as in 1940, in the moderately grazed short-grass type 3 times, and in the overgrazed short-grass type, where buffalo grass was abundant, the increase was nineteenfold.

All but 12 species of forbs disappeared from the short-grass ranges and all but 1 of these were scarce. Increase following drought was from dormant underground parts, from dormant predrought seed, and seed from relict plants. Some species showed no recovery, only a few occurred in normal abundance.

Cactus increased so greatly during drought that it hindered utilization of the grasses. With increased soil moisture, a thickened cover of grasses, and increased humidity about the cactus, its insect enemies thrived and this pest was reduced somewhat to the amount in which it occurred before drought.

\section{LITERATURE CITED}

Albertson, F. W. 1937. Ecology of mixed prairie in west central Kansas. Ecol. Monog. 7 : 481-547.

1938. Prairie studies in west central Kansas. Kan. Acad. Sci. Trans. 41 : 77-83.

1939. Prairie studies in west central Kansas. Kan. Acad. Sci. Trans. 42: 97-107.

1941. Prairie studies in west central Kansas. Kan. Acad. Sci. Trans. 44 : 48-57.

Albertson, F. W., \& J. E. Weaver. 1942. History of the native vegetation of western Kansas during seven years of continuous drought. Ecol. Monog. 12: 23-51. 1944. Effects of drought, dust, and intensity of grazing on cover and yield of short-grass pastures. Ecol. Monog. 14 : 1-29.

Blake, A. K. 1935. Viability and germination of seeds and early life history of prairie plants. Ecol. Monog. 5: $405-460$.

Clark, 0. R. 1937. Interception of rainfall by herbaceous vegetation. Science 86: 591-592.

1940. Interception of rainfall by prairie grasses, weeds, and certain crop plants. Ecol. Monog. 10: 243-277.

Clements, F. E. 1936. Nature and structure of the climax. Jour. Ecol. 24 : 253-284.

Clements, F. E., \& R. W. Chaney. 1937. Environment and life in the Great Plains. Carnegie Inst. Wash. Suppl. Pub. 24.

Clements, F. E., \& J. E. Weaver. 1924. Experimental vegetation. Carnegie Inst. Wash. Pub. 355.

Clements, F. E., J. E. Weaver, \& H. C. Hanson. 1929. Plant competition. Carnegie Inst. Wash. Pub. 398.

Cook, C. W. 1942. Insects and weather as they influence growth of cactus on the central Great Plains. Ecology 23 : 209-214. 
Costello, D. F. 1941. Pricklypear control on the shortgrass range in the central Great Plains. U. S. Dept. Agr. Leaflet 210.

Flory, E. L., \& C. G. Marshall. 1942. Regrassing for soil protection in the southwest. U. S. Dept. Agr. Farmers Bul. 1913.

Fowler, R. L., \& J. E. Weaver. 1940. Occurrence of a disease of side-oats grama. Bul. Torrey Bot. Club 67 : $503-508$.

Great Plains Committee. 1937. The future of the Great Plains. U. S. Govt. Printing Office. Washington, D. C.

Harvey, A. D. 1936. Rootsprouts as a means of vegetative reproduction in Opuntia polyacantha. Jour. Amer. Soc. Agron. 28: 767-768.

Judd, B. I., \& M. L. Jackson. 1939. Natural succession of vegetation on abandoned farm lands in the Rosebud soil area of western Nebraska. Jour. Am. Soc. Agron. 31 : 541-557.

Marsh, L. M. 1940. Water content and osmotic pressure of certain prairie plants in relation to environment. Neb. Univ. Studies 40(3) : 1-44.

McArdle, R. E., \& D. F. Costello. 1936. The virgin range and the white man's toll. U. S. Dept. Agr. Sen. Doc. 199, Sept. 2. Pp. 71-116.

Mueller, I. M. 1941. An experimental study of rhizomes of certain prairie plants. Ecol. Monog. 11 : 165-188.

Mueller, I. M., \& J. E. Weaver. 1942. Relative drought resistance of seedlings of dominant prairie grasses. Ecology 23: 387-398.

Pavlychenko, T. K. 1942. Root systems of certain forage crops in relation to the management of agricultural soils. Nat. Res. Council of Canada and Dom. Dept. Agr. N. R. C. No. 1088.

Robertson, J. H. 1939. A quantitative study of trueprairie vegetation after three years of extreme drought. Ecol. Monog. 9: 431-492.

Savage, D. A. 1934. Methods of reestablishing buffalo grass on cultivated land in the Great Plains. U. S. Dept. Agr. Circ. 328.

1937. Drought survival of native grass species in the central and southern Great Plains, 1935. U. S. Dept. Agr. Tech. Bul. 549.

1939. Grass culture and range improvement in the central and southern Great Plains. U. S. Dept. Agr. Circ. 491.

Savage, D. A., \& H. E. Runyon. 1937. Natural revegetation of abandoned farm land in the central and southern Great Plains. Internatl. Grassland Cong., Aberystwyth, Gt. Brit., Rept. Sect. 1. Grassland Ecology, pp. 178-182.

Shantz, H. L. 1911. Natural vegetation as an indicator of the capabilities of land for crop production in the
Great Plains area. U. S. Dept. Agr., Bur. Plant Ind. Bul. 201.

1917. Plant succession on abandoned roads in eastern Colorado. Jour. Ecology 5: 19-42.

Thornton, H. G. 1936. The present state of our ignorance concerning the nodules of leguminous plants. Sci. Progress No. 122.

Timmons, F. L., \& L. E. Wenger. 1940. Jackrabbits and cactus team up; present serious problem in 30 counties. Kansas Farmer 77(8): 5, 22.

Tolstead, W. L. 1941. Plant communities and secondary succession in south-central South Dakota. Ecology 22: $322-328$.

Turner, G. T., \& D. F. Costello. 1942. Ecological aspects of the pricklypear problem in eastern Coloradó and Wyoming. Ecology 23: 419-426.

Weaver, J. E. 1924. Plant production as a measure of environment. Jour. Ecology 12: 205-237.

1942. Competition of western wheat grass with relict vegetation of prairie. Amer. Jour. Bot. 29: 366-372. 1943. Replacement of true prairie by mixed prairie in eastern Nebraska and Kansas. Ecology 24: 421434.

Weaver, J. E., \& F. W. Albertson. 1936. Effects of the great drought on the prairies of Iowa, Nebraska, and Kansas. Ecology 17: 567-639.

1939. Major changes in grassland as a result of continued drought. Bot. Gaz. 100: 576-591.

1940. Deterioration of grassland from stability to denudation with decrease in soil moisture. Bot. Gaz. 101 : 598-624.

1940a. Deterioration of midwestern ranges. Ecology 21 : $216-236$.

1943. Resurvey of grasses, forbs, and underground plant parts at the end of the great drought. Ecol. Monog. 13: 63-117.

Weaver, J. E., \& R. W. Darland. 1944. Grassland patterns in 1940. Ecology 25: 202-215.

Weaver, J. E., \& T. J. Fitzpatrick. 1932. Ecology and relative importance of the dominants of tall-grass prairie. Bot. Gaz. 93: 113-150.

1934. The prairie. Ecol. Monog. 4: 109-295.

Weaver, J. E., \& W. W. Hansen. 1941. Native midwestern pastures-their origin, composition, and degeneration. Univ. Neb. Cons. and Surv. Div. Bul. 22. 1941a. Regeneration of native midwestern pastures under protection. Univ. Neb. Cons. and Surv. Div. Bul. 23.

Weaver, J. E., \& I. M. Mueller. 1942. Role of seed lings in recovery of midwestern ranges from drought. Ecology 23: 275-294.

Weaver, J. E., L. A. Stoddart, \& W. Noll. 1935. Response of the prairie to the great drought of 1934. Ecology 16: 612-629.

Wilson, C. P. 1931. The artificial reseeding of New Mexico ranges. New Mex. Agr. Exp. Sta. Bul. 189. 